\title{
Improving patient selection and outcome of stereotactic radiosurgery as a single treatment modality for brain metastases
}

Citation for published version (APA):

Zindler, J. D. (2017). Improving patient selection and outcome of stereotactic radiosurgery as a single treatment modality for brain metastases. [Doctoral Thesis, Maastricht University]. Datawyse / Universitaire Pers Maastricht. https://doi.org/10.26481/dis.20171025jz

Document status and date:

Published: 01/01/2017

DOI:

10.26481/dis.20171025jz

Document Version:

Publisher's PDF, also known as Version of record

Please check the document version of this publication:

- A submitted manuscript is the version of the article upon submission and before peer-review. There can be important differences between the submitted version and the official published version of record.

People interested in the research are advised to contact the author for the final version of the publication, or visit the DOI to the publisher's website.

- The final author version and the galley proof are versions of the publication after peer review.

- The final published version features the final layout of the paper including the volume, issue and page numbers.

Link to publication

\footnotetext{
General rights rights.

- You may freely distribute the URL identifying the publication in the public portal. please follow below link for the End User Agreement:

www.umlib.nl/taverne-license

Take down policy

If you believe that this document breaches copyright please contact us at:

repository@maastrichtuniversity.nl

providing details and we will investigate your claim.
}

Copyright and moral rights for the publications made accessible in the public portal are retained by the authors and/or other copyright owners and it is a condition of accessing publications that users recognise and abide by the legal requirements associated with these

- Users may download and print one copy of any publication from the public portal for the purpose of private study or research.

- You may not further distribute the material or use it for any profit-making activity or commercial gain

If the publication is distributed under the terms of Article $25 \mathrm{fa}$ of the Dutch Copyright Act, indicated by the "Taverne" license above, 


\section{Improving Patient Selection and Outcome of Stereotactic Radiosurgery as a Single Treatment Modality for Brain Metastases}


C copyright Jaap Zindler, Maastricht 2017

Illustratie voorkant. Hennie van der Steeg, kunstenaar, Nieuwstadt, juli 2017 (sjannie.vdsteeg@gmail.com)

Printing: Datawyse | Universitaire Pers Maastricht

ISBN 9789461597618

Copyrights of the following chapters belong to the publisher and permission is obtained for inclusion in this thesis

Chapter 2 Radiother Oncol 2013 Mar;106(3):370-4 (C) copyright Elsevier https://doi.org/10.1016/j.radonc.2013.01.015

Chapter 3 The Oncologist 2013;18(3):330-5. C copyright AlphaMed Press https://doi.org/10.1634/theoncologist.2012-0316

Chapter 4 Radiother Oncol. 2014 Apr;111(1):52-8 (C) copyright Elsevier https://doi.org/10.1016/j.radonc.2013.11.015

Chapter 5 Radiother Oncol. 2014 Jul 28.S0167-8140(14)00293 (C) copyright Elsevier https://doi.org/10.1016/j.radonc.2014.07.007

Chapter 6 Radiother Oncol. 2017 May;123(2):189-194 (C) copyright Elsevier https://doi.org/10.1016/j.radonc.2017.02.006

Chapter 7 Dutch Journal of Oncology 2013;10(8):318-23 (c) copyright Ariez Medical Publishing http://www.ariez.nl/DownloadFile.lynkx?guid=799cfad9-0f7b-4afc-92a8-38bc021b8188

Chapter 8 BMC Cancer 2017 Jul 25;17(1):500 (C) copyright BioMed Central https://doi.org/10.1186/s12885-017-3494-z

Chapter 9 Radiother Oncol. 2013 Feb;106(2):206-9 (c) copyright Elsevier https://doi.org/10.1016/j.radonc.2012.10.014

Chapter $10 \mathrm{~J}$ Natl Cancer Inst. 2015 Oct 16;108(2) (C) copyright Oxford University Press. https://doi.org/10.1093/jnci/djv305

Chapter 11 Submitted for publication (c) copyright Springer International Publishing AG 


\title{
Improving Patient Selection and Outcome of Stereotactic Radiosurgery as a Single Treatment Modality for Brain Metastases
}

\author{
PROEFSCHRIFT \\ ter verkrijging van de graad van doctor aan de Universiteit Maastricht, \\ op gezag van de Rector Magnificus, Prof dr. Rianne M. Letschert \\ volgens het besluit van het College van Decanen, \\ in het openbaar te verdedigen \\ op woensdag 25 oktober 2017 om 16:00 uur \\ door \\ Jaap Doeke Zindler \\ geboren op 23 oktober 1979 \\ te Haarlem
}




\section{Promotor}

Prof. dr. P. Lambin

\section{Copromotores}

Dr. ir. A.L. Hoffmann, Technische Universität Dresden/Universitätsklinikum Carl Gustav Carus Dresden, Duitsland

Dr. A. Jochems

Dr. F. J. Lagerwaard, VUmc Amsterdam

\section{Beoordelingscommissie}

Prof. dr. D. de Ruysscher (voorzitter)

Prof. dr. ir. A.L.A.J. Dekker

Prof. dr. A.M. Dingemans

Dr. P.J. Koehler, Zuyderland ziekenhuis, Heerlen

Dr. R. Wiggenraad, Haaglanden medisch centrum, Den Haag 


\section{Contents}

Chapter 1 Introduction

Chapter 2 The clinical utility of prognostic scoring systems in patients with brain metastases treated with radiosurgery

Radiother Oncol 2013 Mar;106(3):370-4

Chapter 3 Recursive Partitioning Analysis for the Prediction of Stereotactic

Radiosurgery Brain Metastases Lesion Control The Oncologist 2013;18(3):330-5

Chapter 4 A Clinical Nomogram and Recursive Partitioning Analysis to Determine the Risk of Regional Failure after Radiosurgery Alone for Brain Metastases 45 Radiother Oncol. 2014 Apr;111(1):52-8

Chapter 5 Patterns of distant brain recurrences after radiosurgery alone for newly diagnosed brain metastases: Implications for salvage therapy Radiother Oncol. 2014 Jul 28.50167-8140(14)00293

Chapter 6 Individualized early death and long-term survival prediction after stereotactic radiosurgery for brain metastases of non-small cell lung cancer: two externally validated nomograms Radiother Oncol. 2017 May;123(2):189-194

Chapter 7 Postoperative management after resection of a single brain metastasis: whole brain radiotherapy, local radiotherapy, or 'wait and scan'?

Dutch Journal of Oncology 2013;10(8):318-23

Chapter 8 Whole brain radiotherapy versus Stereotactic Radiosurgery for 4 - 10 brain metastases: a phase III randomized multicenter trial BMC Cancer $2017 \mathrm{Jul}$ 25;17(1):500

Chapter 9 Propensity-score matched pair comparison of whole brain with simultaneous in-field boost radiotherapy and stereotactic radiosurgery 109 Radiother Oncol. 2013 Feb;106(2):206-9

Chapter 10 Increasing the Therapeutic Ratio of Stereotactic Ablative Radiotherapy by Individualized Isotoxic Dose Prescription J Natl Cancer Inst. 2015 Oct 16;108(2) 
Chapter 11 Individualized isotoxic dose prescription for stereotactic radiotherapy in large brain metastases: an in-silico study Submitted

Chapter 12 General discussion and future perspectives

Summary

Samenvatting

Valorisation

Dankwoord

Curriculum vitae

List of peer reviewed publications

189

Scientific presentations at international and national conferences 
Chapter

Introduction 

Brain metastases (BM) are the most common intracranial malignant neoplasm in adults and occur in up to $25 \%$ to $35 \%$ of metastasized cancer patients and in $9 \%$ of all patients diagnosed with cancer.[1,2] BM originate from lung cancer $( \pm 60 \%)$, breast cancer $( \pm$ $10 \%)$, colorectal cancer $( \pm 10 \%)$, melanoma $( \pm 5 \%)$, renal cell cancer $( \pm 5 \%)$, or other primary tumors ( $\pm 10 \%)$, and often determine the quality of life and prognosis of cancer patients. Life expectancy is usually expressed in weeks to months, with only a small minority of patients (1-5\%) surviving several years.[3] Therefore, the vast majority of patients is treated with palliative intent, with the aim of maintenance of quality of life and neurologic function and avoidance of neurologic death by intracranial cancer progression.

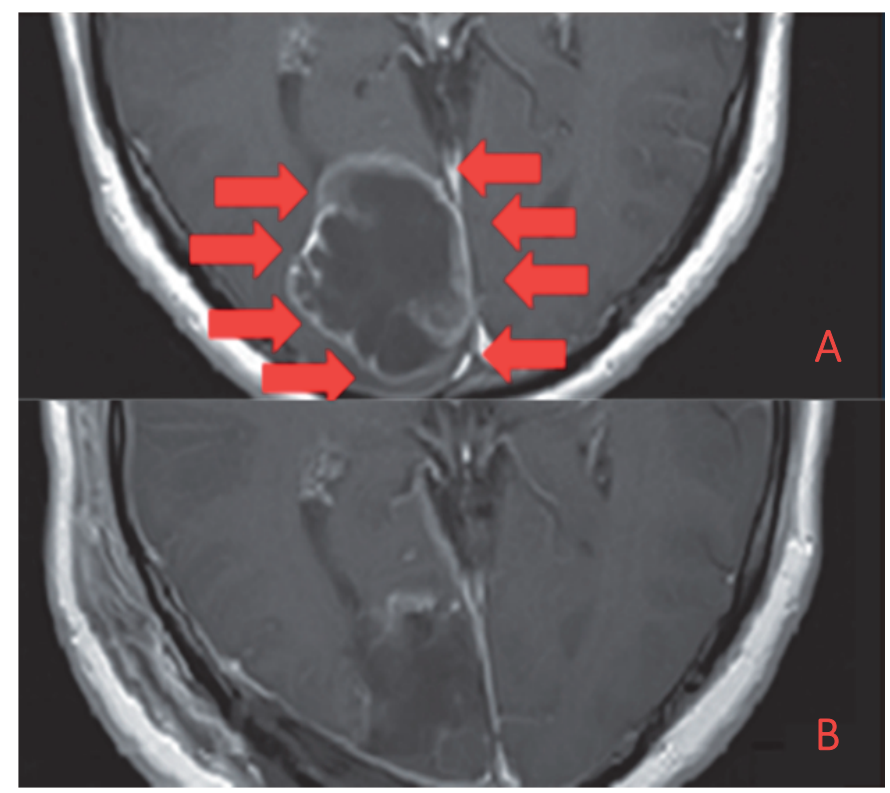

Figure 1. Brain metastasis illustrated on T1-weighted magnetic resonance imaging of the brain (marked with red arrows) before (A) and after surgical resection (B).

\section{TREATMENT OPTIONS}

Therapeutic options for patients with BM include surgery, radiation therapy, systemic therapy (or combinations of these), and best supportive care. Surgical resection is performed for accessible, generally single lesions but is reserved for patients with larger BM with significant mass effect or patients for whom histological confirmation of the intracranial tumor is needed (Figure 1).[4] For the vast majority of patients with multiple lesions or active extracranial disease, however, radiation therapy is the preferred treatment choice. 
Traditionally, whole brain radiation therapy (WBRT) has been the cornerstone of treatment for (multiple) BM. Typically, a homogenous radiation dose is delivered in 5-10 fractions to the entire brain, including the BM.[5] Prognosis after WBRT remains poor, with a median survival of approximately 2-6 months. The most important prognostic factors are the patient's performance status, the presence or absence of extracranial tumor activity, and age. Although WBRT is still being used frequently in clinical practice, its exact palliative value compared to best supportive care is still a matter of debate.[6] WBRT causes several side effects, such as temporary hair loss, fatigue, and neurocognitive damage.[7] Therefore, in patients having a poor prognosis with estimated survival measured in weeks, withholding WBRT seems to be appropriate.[6,8]

\section{STEREOTACTIC RADIOSURGERY}

In the past few decades, an alternative focal radiation treatment has become available for patients with a limited number of BM: stereotactic radiosurgery (SRS). The technology and principle of SRS was developed by the Swedish neurosurgeon Lars Leksell in 1949. SRS differs from WBRT in that only the BM volume is treated and the uninvolved brain tissue is spared to as much as possible (Figure 2). The delivered radiation dose to the BM with SRS is biologically much larger than WBRT, resulting in a higher tumor control probability. Being a minimally or non-invasive treatment modality, the morbidity and mortality of general anesthesia and surgical resection is avoided.[9-11] SRS is delivered at an outpatient clinic with avoidance of the hospitalization needed with surgery. Tumor cells are destroyed by the usage of multiple photon beams generally in 1 up to 3 fractions. Side effects such as neurocognitive damage and hair loss of WBRT is mostly avoided because of the local nature of SRS.[12] With a single SRS dose of $\geq 18$ Gy, reported 1 year local control rates vary from $73 \%$ up to $98 \%$, dependent on size and primary tumor type of the BM. In general, for small BM, SRS can be regarded as equally effective as resection, but surgical resection can be more appropriate for larger metastases $\left(>8-10 \mathrm{~cm}^{3}\right)$. The disadvantage of SRS is the relatively high cumulative risk of development or outgrowth of new BM during follow-up in the non-irradiated parts of the brain. However, salvage therapy in the form of repeat-SRS, WBRT, or even surgery can be applied in selected patients.[13] The efficacy of SRS alone or given in combination with WBRT for patients with BM has been investigated in several studies.[10,13-15] These studies showed comparable median overall survival rates in patients with 1-4 brain metastases treated with SRS alone vs SRS plus WBRT, suggesting that WBRT could be omitted in the initial management of brain metastases. Patients who received WBRT in addition to SRS or surgery experienced poorer neurocognitive function, more fatigue, more hair loss, and in general a decreased quality of life compared to SRS or resection only.[10,11] 
Another disadvantage of SRS is the risk of causing a complication called radiation necrosis (RN). RN is focal structural damage of the nearby brain tissue that may cause permanent neurologic symptoms. Patients suffering from RN can become dependent on medication (corticosteroids) or even require surgical treatment to relieve the neurologic symptoms. The risk of RN is dependent on the volume of surrounding healthy brain tissue being exposed to high doses. For single-fraction SRS, the volume of healthy brain tissue receiving $12 \mathrm{~Gy}\left(V_{12 \mathrm{~Gy}}\right)$ is considered the most significant prognostic factor for RN. If the $V_{12 G y}$ is kept below ca. $10 \mathrm{~cm}^{3}$, the risk of RN has been described as less than $10 \%$. The risk of surpassing this threshold mainly occurs when irradiating larger $(>2 \mathrm{~cm}$ in diameter) BM with SRS, which increases the risk of RN.[16-18]
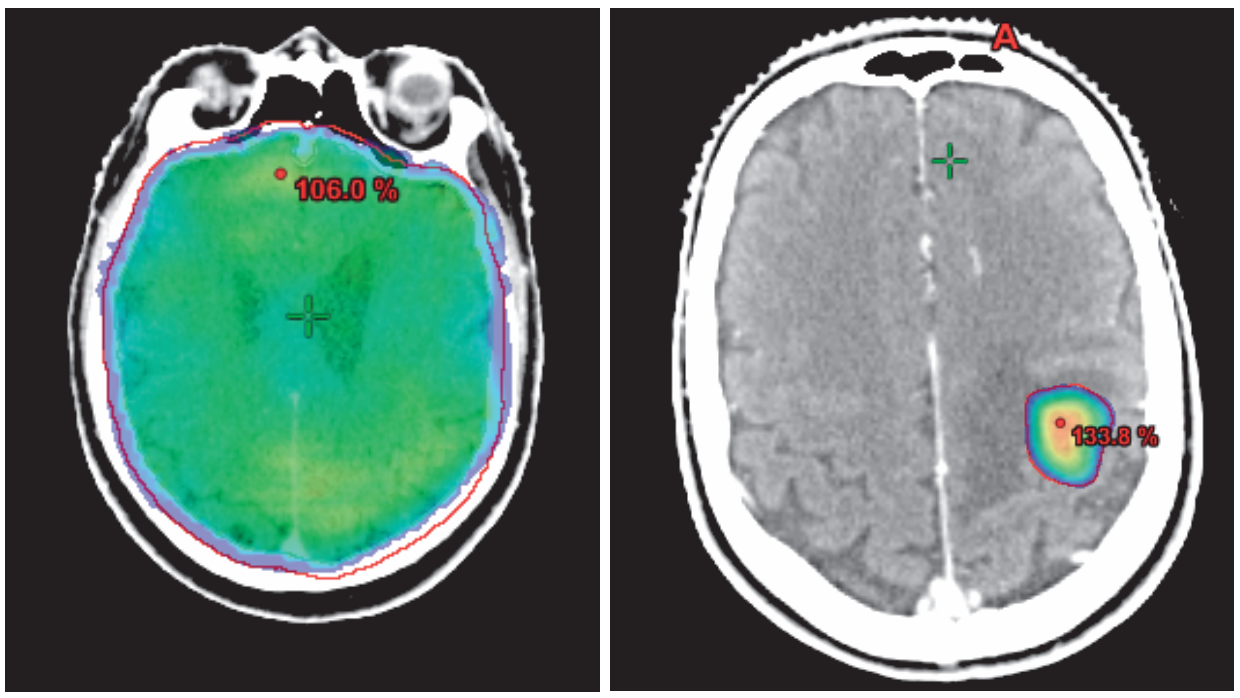

Figure 2. Color-wash representation of a typical dose distribution for WBRT (left) and SRS (right).

The technology to deliver SRS has developed rapidly over the past few decades (Figure 3). At present, even multiple BM can be treated with a single-fraction within minutes with advanced and patient friendly techniques. The patient is positioned in a custommade mask, which renders the use of invasive frames obsolete. Modern onboard technologies, such as cone-beam CT or orthogonal imaging, allow for accurate positioning of the patients with sub-millimeter precision. With modern dedicated LINACs, SRS can be delivered with comparable plan quality as other radiation therapy devices, such as the Gamma Knife (GK). LINAC-based SRS offers comparable plan conformity and dose gradients as GK. $[19,20]$ SRS (either LINAC based or with GK) is currently the standard treatment according to Dutch guidelines for patients with a maximum of 3 BM.[21] 


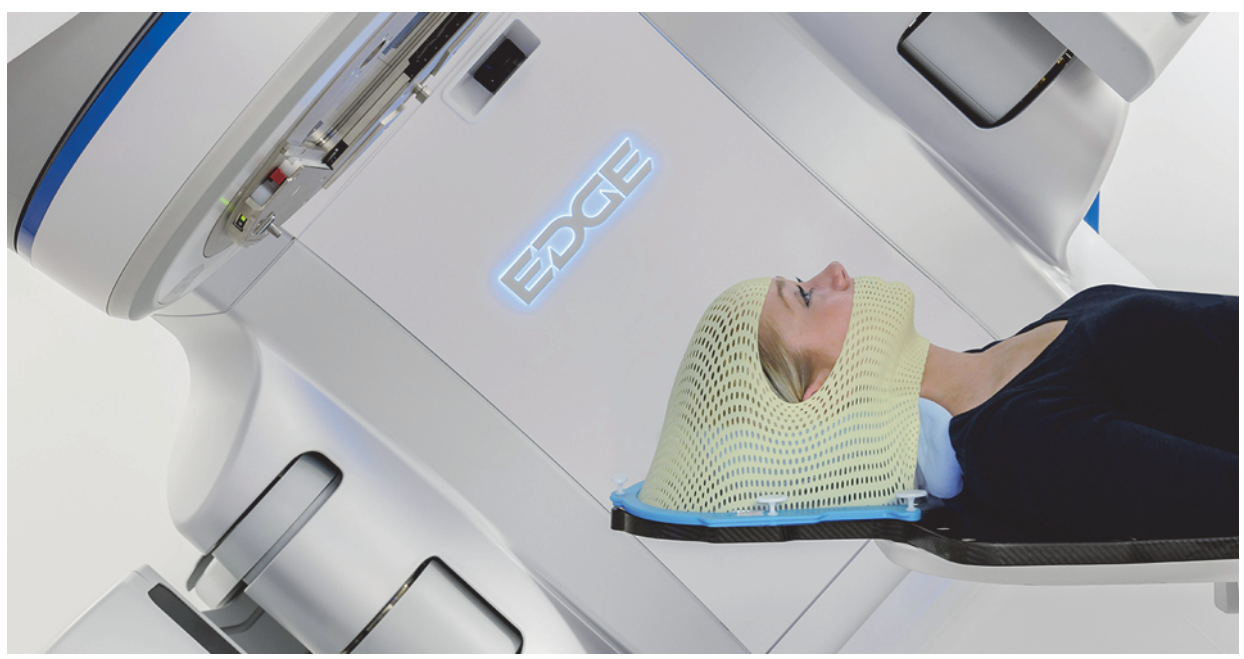

Figure 3. Frameless mask for convenient patient positioning. (Image courtesy of Varian Medical Systems, Palo Alto, CA, USA).

\section{PATIENT SELECTION FOR SRS}

Being both efficient and patient friendly, SRS alone has become an attractive treatment option for patients with BM. It remains important to identify patients whose expected survival justifies application of SRS, and several prognostic classification systems that have been developed can be used to estimate life expectancy. However, the currently available prognostic classification systems suffer from several limitations, as the patient cohorts on which these classifiers have been trained and validated were mainly treated with other modalities than SRS alone, such as WBRT. Moreover, the predicted treatment outcome probability is presented for groups of patients with poor, intermediate, or favorable prognoses, instead of for individual patients. Outside of trial settings, the proportion of patients in the intermediate prognostic group dominates the proportion of patients in both the favorable and poor prognostic classes. In the current era in which systemic agents also may control BM, potentially relevant tumor characteristics have not been incorporated into prognostic classification systems.[22,23] Considering the limitations of currently available prognostic classification systems, there is an urgent need to develop individualized prediction tools per treatment modality and per outcome parameter, incorporating all relevant prognostic factors. These individualized prediction tools may help both physicians and (ultimately) patients choose the optimal treatment strategy for each patient with BM. Assessing the value of current clinical outcome prediction tools, specifically for patients treated with SRS alone, followed by the generation of an individualized outcome prediction tool is the subject of the first part of this thesis. 


\section{EFFECTIVENESS OF SRS AS A SINGLE MODALITY TREATMENT IN PATIENTS WITH MULTIPLE BM}

Technical advances that have been accomplished in the past few decades with LINACbased SRS have paved the way to treat patients with more than $3 \mathrm{BM}$. According to current Dutch guidelines, WBRT is the standard of care in patients with more than 3 BM. There is a tendency of better survival after WBRT in patients with a favorable prognostic profile by early sterilization of microscopic disease, but as mentioned before, some side effects of WBRT can be avoided with SRS.[9,15] Therefore the effectiveness and safety of SRS alone compared to standard-of-care WBRT needs to be determined in randomized studies in patients with more than $3 \mathrm{BM}$ before this treatment can be applied in general clinical practice. The second goal in this thesis was the description of the background of the need for a prospective studies in patients with more than $3 \mathrm{BM}$ and the actual initiation of a phase III randomized trial to determine which treatment provides the best quality of life in patients with 4 to $10 \mathrm{BM}$.

\section{Improving SRS outcome for large BM}

Another challenge in current daily clinical practice with SRS for BM is its application in large BM. The majority of institutes in the Netherlands use a risk-adaptive approach, in which $\mathrm{BM}$ with a small volume $\left(<10 \mathrm{~cm}^{3}\right.$ ) are treated with high doses (a single fraction of 21 or $24 \mathrm{~Gy}$ ), and BM with a larger volume are treated with lower prescribed doses (a single fraction of 15 or $18 \mathrm{~Gy}$ ). In this way, high local control rates at 1 year (ca. 85\%) and low risk of RN (<10\%) can be achieved for small BM, whereas for larger BM, a very high risk of $\mathrm{RN}$ is avoided at the cost of a lower tumor control probability (ca. $40 \%) .[24,25]$ To safely increase the probability of local control while maintaining a low risk of RN in patients with larger BM undergoing SRS, there is a clear need to optimize the risk-adaptive approach for single-fraction SRS.

Hence, the third goal of this thesis was to perform a modelling study to test an individualized dose prescription strategy to safely improve the tumor control probability with SRS for larger BM.

\section{HYPOTHESES OF THIS THESIS}

(1) Individualized prognostic models predict survival and the occurrence of distant brain recurrences after SRS alone for BM more accurately than currently available prognostic models

(2) A multicenter randomized phase III trial can be initiated to investigate whether SRS alone provides a better quality of life than WBRT in patients with 4 to 10 BM 
(3) The 1-year tumor control probability of SRS for large BM can be improved by isotoxic dose prescription in a modelling study

\section{OUTLINE OF THIS THESIS}

In Figure 4 the outline of this thesis is presented.

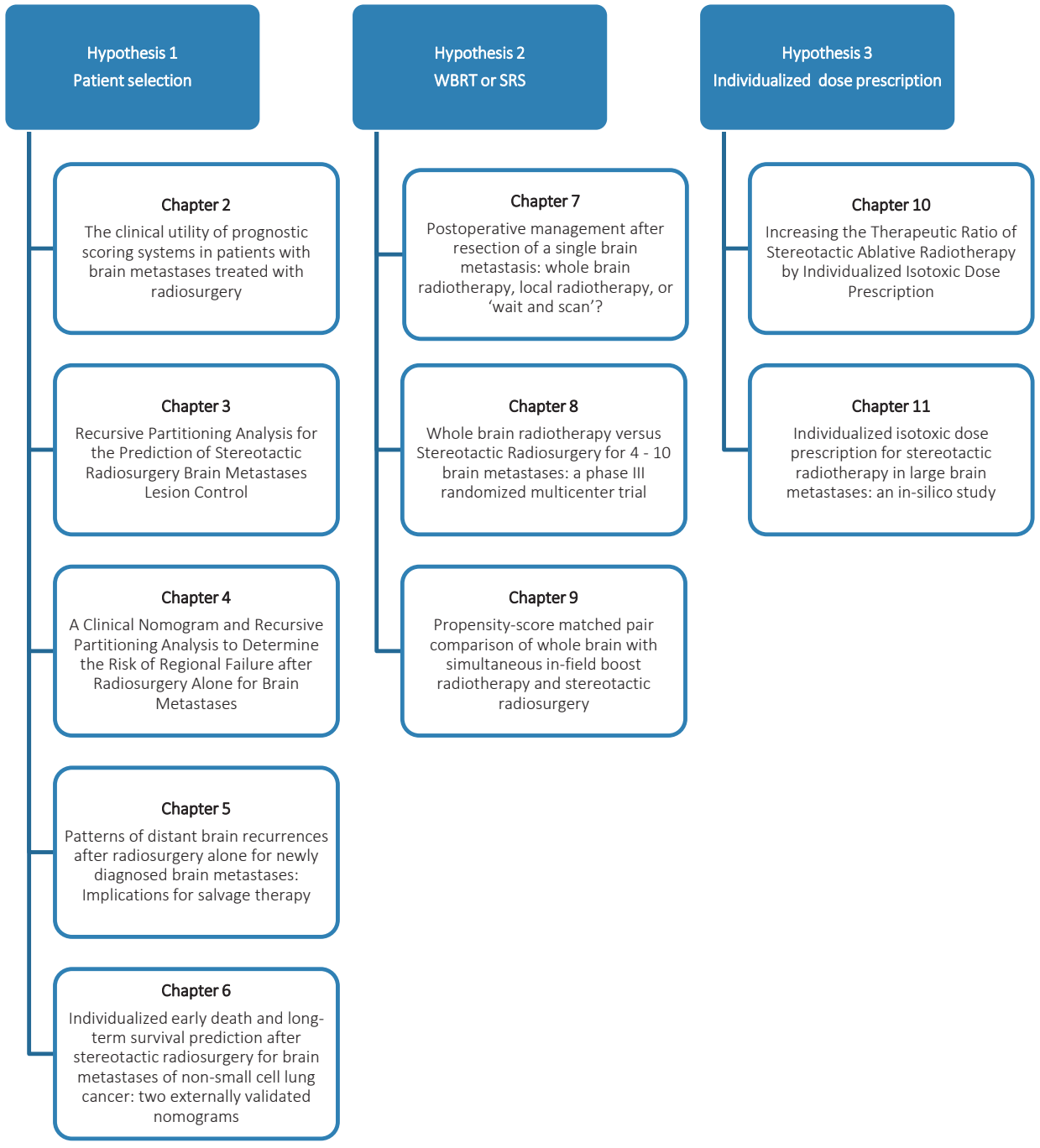

Figure 4 Outline of this thesis 
The first 5 chapters address the first hypothesis of this thesis. In chapter 2, the value and limitations of several currently available prognostic models are discussed with respect to survival prediction. In chapters 3 to 6 , newly developed prediction models are described for different clinical endpoints after SRS alone for BM: survival, local control, and distant brain recurrences. In chapters 7 to 9 the second hypothesis was tested. In these chapters, the value of SRS, WBRT, resection, or a combination is provided for patients with BM and a study protocol is described of a randomized trial. The third hypothesis is discussed in chapters 10 and 11 . Chapter 10 reviews the currently available clinical evidence of isotoxic dose prescription (IDP) for radiotherapy and especially its value with SRS. Chapter 11 is a modelling study and describes the application of IDP for SRS in large BM. 


\section{REFERENCES}

[1] www.kankerregistratie.nl

[2] Schouten L, Rutten J, Huveneers HA, Twijnstra A. Incidence of brain metastases in a cohort of patients with carcinoma of the breast, colon, kidney, and lung and melanoma. Cancer. 2002 May 15;94(10):2698705

[3] Zindler JD, Rodrigues G, Haasbeek CJ, Haan PF, Meijer OW, Slotman BJ, Lagerwaard FJ. The clinical utility of prognostic scoring systems in patients with brain metastases treated with radiosurgery. Radiother Oncol 2013 Mar;106(3):370-4.

[4] Patchell RA, Tibbs PA, Walsh JW, Dempsey RJ, Maruyama Y, Kryscio RJ, et al. A randomized trial of surgery in the treatment of single metastases to the brain. N Engl J Med 1990 Feb 22;322(8):494-500.

[5] Cairncross JG, Kim JH, Posner JB. Radiation therapy for brain metastases. Ann Neurol 1980;7:529-541.

[6] Mulvenna P, Nankivell M, Barton R, Faivre-Finn C, Wilson P, McColl E, Moore B, Brisbane I, Ardron D, Holt T, Morgan S, Lee C, Waite K, Bayman N, Pugh C, Sydes B, Stephens R, Parmar MK, Langley RE. Dexamethasone and supportive care with or without whole brain radiotherapy in treating patients with nonsmall cell lung cancer with brain metastases unsuitable for resection or stereotactic radiotherapy (QUARTZ): results from a phase 3, non-inferiority, randomised trial. Lancet. 2016 Oct 22;388(10055):2004-2014.

[7] Pinkham MB, Sanghera P, Wall GK, Dawson BD, Whitfield GA. Neurocognitive Effects Following Cranial Irradiation for Brain Metastases. Clin Oncol (R Coll Radiol). 2015 Nov;27(11):630-9.

[8] Hendriks LE, Troost EG, Steward A, Bootsma GP, De Jaeger K, van den Borne BE, Dingemans AM. Patient selection for whole brain radiotherapy (WBRT) in a large lung cancer cohort: Impact of a new Dutch guideline on brain metastases. Acta Oncol. 2014 Jul;53(7):945-51.

[9] Lippitz B, Lindquist C, Paddick I, Peterson D, O'Neill K, Beaney R. Stereotactic radiosurgery in the treatment of brain metastases: the current evidence. Cancer Treat Rev. 2014 Feb;40(1):48-59.

[10] Kocher M, Soffietti R, Abacioglu U, Villà S, Fauchon F, Baumert BG, Fariselli L, Tzuk-Shina T, Kortmann RD, Carrie C, Ben Hassel M, Kouri M, Valeinis E, van den Berge D, Collette S, Collette L, Mueller RP. Adjuvant whole-brain radiotherapy versus observation after radiosurgery or surgical resection of one to three cerebral metastases: results of the EORTC 22952-26001 study. J Clin Oncol. 2011 Jan 10;29(2):134-41.

[11] Soffietti R, Kocher M, Abacioglu UM, Villa S, Fauchon F, Baumert BG, Fariselli L, Tzuk-Shina T, Kortmann RD, Carrie C, Ben Hassel M, Kouri M, Valeinis E, van den Berge D, Mueller RP, Tridello G, Collette L, Bottomley A. A European Organisation for Research and Treatment of Cancer phase III trial of adjuvant whole-brain radiotherapy versus observation in patients with one to three brain metastases from solid tumors after surgical resection or radiosurgery: quality-of-life results. J Clin Oncol. 2013 Jan 1;31(1):6572.

[12] Zindler JD, Slotman BJ, Lagerwaard FJ. Patterns of distant brain recurrences after radiosurgery alone for newly diagnosed brain metastases: Implications for salvage therapy. Radiother Oncol. 2014 Jul 28.S01678140(14)00293

[13] Sneed PK, Suh JH, Goetsch SJ, Sanghavi SN, Chappell R, Buatti JM, Regine WF, Weltman E, King VJ, Breneman JC, Sperduto PW, Mehta MP. A multi-institutional review of radiosurgery alone vs. radiosurgery with whole brain radiotherapy as the initial management of brain metastases. Int J Radiat Oncol Biol Phys. 2002 Jul 1;53(3):519-26.

[14] Andrews DW, Scott CB, Sperduto PW, Flanders AE, Gaspar LE, Schell MC, Werner-Wasik M, Demas W, Ryu J, Bahary JP, Souhami L, Rotman M, Mehta MP, Curran WJ Jr. Whole brain radiation therapy with or without stereotactic radiosurgery boost for patients with one to three brain metastases: phase III results of the RTOG 9508 randomised trial. Lancet. 2004 May 22;363(9422):1665-72.

[15] Aoyama H, Tago M, Shirato H; Japanese Radiation Oncology Study Group 99-1 (JROSG 99-1) Investigators. Stereotactic Radiosurgery With or Without Whole-Brain Radiotherapy for Brain Metastases: Secondary Analysis of the JROSG 99-1 Randomized Clinical Trial. JAMA Oncol. 2015 Jul;1(4):457-64 
[16] Shaw E, Scott C, Souhami L, Dinapoli R, Kline R, Loeffler J, Farnan N. Int J Radiat Oncol Biol Phys. Single dose radiosurgical treatment of recurrent previously irradiated primary brain tumors and brain metastases: final report of RTOG protocol 90-05. 2000;47:291-298.

[17] Minniti G, Clarke E, Lanzetta G, Osti MF, Trasimeni G, Bozzao A, Romano A, Enrici RM. Stereotactic radiosurgery for brain metastases: analysis of outcome and risk of brain radionecrosis. Radiat Oncol. 2011 May 15;6:48

[18] Blonigen BJ, Steinmetz RD, Levin L, Lamba MA, Warnick RE, Breneman JC. Irradiated volume as a predictor of brain radionecrosis after linear accelerator stereotactic radiosurgery. Int J Radiat Oncol Biol Phys. 2010 Jul 15;77(4):996-1001.

[19] Thomas EM, Popple RA, Wu X, Clark GM, Markert JM, Guthrie BL, Yuan Y, Dobelbower MC, Spencer SA, Fiveash JB. Comparison of plan quality and delivery time between volumetric arc therapy (RapidArc) and Gamma Knife radiosurgery for multiple cranial metastases. Neurosurgery. 2014 Oct;75(4):409-17.

[20] Park HS, Wang EH, Rutter CE, Corso CD, Chiang VL, Yu JB. Changing practice patterns of Gamma Knife versus linear accelerator-based stereotactic radiosurgery for brain metastases in the US. J Neurosurg. 2016 Apr;124(4):1018-24.

[21] Gijtenbeek JM, Ho VK, Heesters MA, Lagerwaard FJ, de Graeff A, Boogerd W. Practice guideline 'Brain metastases'. Ned Tijdschr Geneeskd. 2011;155(52):A4141.

[22] Bergen ES, Berghoff AS, Rudas M, Preusser M, Bartsch R. Breast cancer brain metastases responding to lapatinib plus capecitabine as second-line primary systemic therapy. Anticancer Drugs. 2015 Jun;26(5):579-81.

[23] Basnet A, Saad N, Benjamin S. A Case of Vanishing Brain Metastasis in a Melanoma Patient on Nivolumab. Anticancer Res. 2016 Sep;36(9):4795-8.

[24] Wiggenraad R, Verbeek-de Kanter A, Kal HB, Taphoorn M, Vissers T, Struikmans H. Dose-effect relation in stereotactic radiotherapy for brain metastases. A systematic review. Radiother Oncol. 2011 Mar;98(3):292-7.

[25] www.predictcancer.org 

Chapter

\section{The clinical utility of prognostic scoring systems in patients with brain metastases treated with radiosurgery}




\section{ABSTRACT}

Purpose The RTOG recursive partitioning analysis (RPA) classification is the gold standard for assessing the prognosis of patients with brain metastases (BM). Newer prognostic scoring systems for BM patients have been proposed, but their superiority over RPA needs to be established for patients treated with radiosurgery.

Methods 380 patients with 1-3 BM were treated at the VUmc with radiosurgery (RS) from 2002 to 2011. Using baseline characteristics, patient scores were calculated for RPA, the Rotterdam-system, the score index for radiosurgery (SIR), the basic score for BM (BSBM), the graded prognostic assessment (GPA), the diagnosis-specific GPA, the Rades score, and the Golden grading system (GGS) for comparison with survival time and survival classification ( $\leq 3$ months or $\geq 12$ months).

Results Median survival after RS was 7.7 months, with 3-month and 1-year overall survival (OS) of $76 \%$ and $39 \%$, respectively. Multivariate analysis confirmed the prognostic value of performance status, age, absence of extracranial metastases, primary tumor site, gender, and steroid response for OS. The percentage of patients included within the intermediate prognostic classes ranged from $48 \%$ to $77 \%$, and was $64 \%$ for the RPA. All scoring systems highly correlated with OS ( $p<0.001)$. The specificity for predicting early death ranged from $85 \%$ to $98 \%$ (RPA 88\%), with the unfavorable classes of Rades, GGS, BSBM and SIR performing best. The sensitivity for predicting long-term survival ranged from $10 \%$ to $69 \%$ (RPA $29 \%$ ), and was highest for the favorable classes of Rades and GGS.

Conclusions All prognostic scoring systems correlated very well with OS. All scores shared the limitation of unbalanced proportions of patients within the prognostic classes. As the clinical superiority of more recently developed prognostic scoring systems was only modest in predicting early death and long term survival, the well-known and easy to use RPA system currently remains the standard. 


\section{INTRODUCTION}

Stereotactic radiosurgery (RS) is an established treatment modality for patients with a limited number of brain metastases (BM) from solid tumors [1]. In patients treated with RS with or without upfront whole brain radiotherapy (WBRT) [2], median survival duration ranges from 6 to 12 months [3] and [4]. The increasing availability of RS facilities and the introduction of frameless RS techniques has considerably lowered the threshold for the application of RS in terms of patient condition, tumor status and number of BMs. Although modern frameless RS is generally considered to be a well tolerated patientfriendly technique, it remains a time-consuming and relatively costly treatment modality for palliation, underscoring the need for appropriate patient selection.

Many prognostic factors for the survival of patients with BM have been identified in the medical literature including performance status, presence or absence of extracranial metastases, primary tumor control, and age. In order to facilitate the use of these prognostic factors in clinical practice, Gaspar et al. published the recursive partitioning analysis (RPA) prognostic classification system, which was derived from patient groups treated with WBRT in several RTOG studies [5]. The RPA classification which is still the most commonly used prognostic classification system was subsequently validated for patients treated with RS [6] and [7] and surgery [8]. However, the unbalanced distribution of patients within the three RPA classes with the majority of patients included in the intermediate group remains the major limitation of this classification system [9].

In an attempt to improve the clinical utility of prognostic classification systems, several alternatives to the RPA have been published; i.e. the Rotterdam score [10], the scoring index for radiosurgery (SIR) [11], the basic score for BM (BSBM) [12], the graded prognostic assessment (GPA) [13], disease-specific GPA (DS-GPA) [14], Rades score [15], and the Golden grading system (GGS) [16]. All classification systems share two common factors performance status and absence or presence of extracranial metastases, but differ by the addition of other prognostic factors such as age, primary tumor control, site of primary tumor, volume and number of BM, time interval between the diagnosis of the primary tumor and BM, and clinical response to steroid treatment (Table 1). The different classification systems also vary with respect to the patient population that these were derived from; the SIR, BSBM, and GGS were developed in RS patients, the RPA was based on WBRT patients, whereas the Rotterdam, Rades, GPA, and DS-GPA were derived from patient populations treated with WBRT, surgery, RS or a combination of treatment modalities. 
Table 1 Baseline characteristics included in various prognostic scoring systems for patients with brain metastases. Legend: Recursive partitioning analysis (RPA), Rotterdam score (Rotterdam), the scoring index for radiosurgery (SIR), basic score for brain metastases (BSBM), graded prognostic assessment (GPA), diseasespecific GPA (DS-GPA), Rades score, and Golden grading system (GGS)

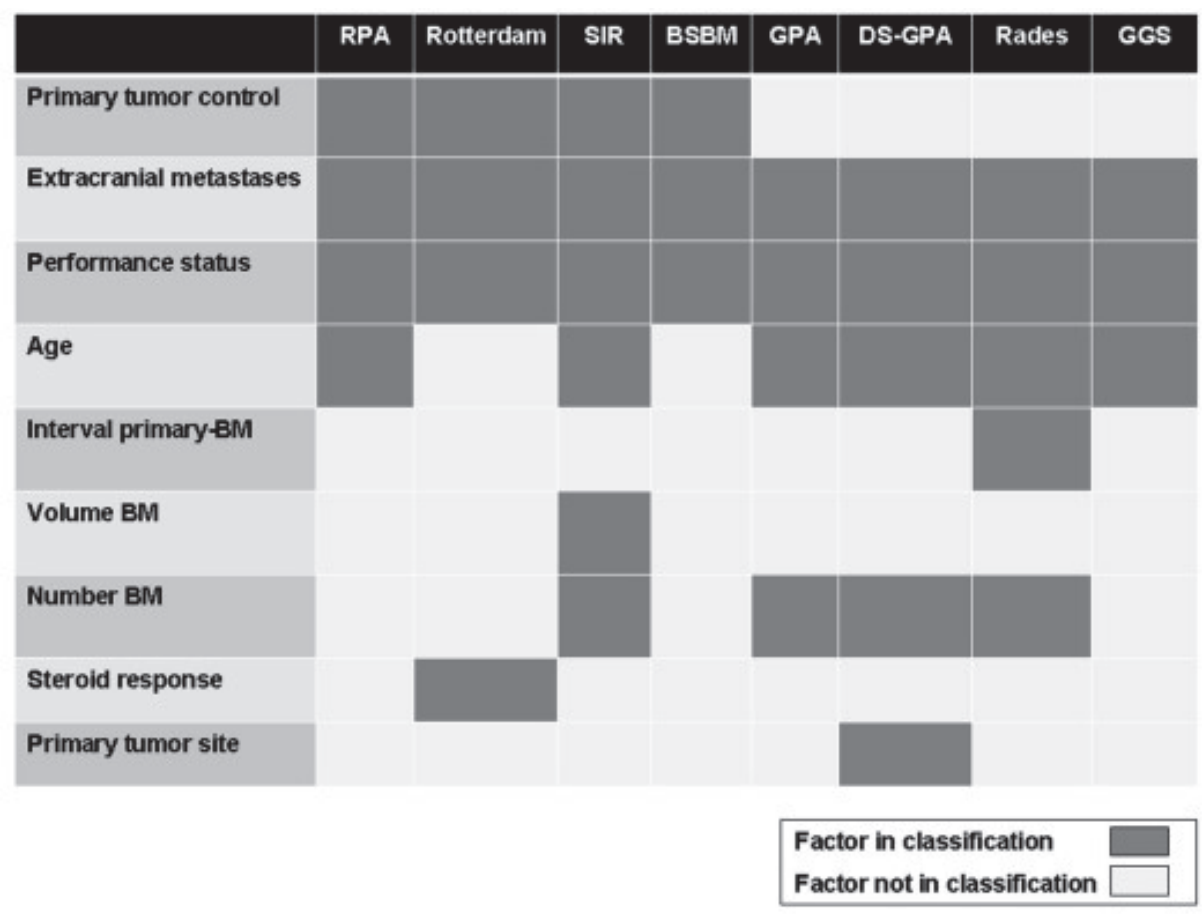

It remains unclear whether newer proposed classification systems perform better than the current standard of RPA in BM patients treated with RS. An optimal prognostic classification system with a high clinical utility should not only be correlated with overall survival, but should also be able to identify patients who are likely to have short survival (e.g. $\leq 3$ months) despite adequate treatment or alternatively identify patients who are likely to have long-term (e.g. $\geq 12$ months) survival. In addition, these should result in a balanced distribution of patients in clinical practice and be as simple as possible for use in clinical practice. Such an optimal classification system would allow for a better selection of patients suitable and less suitable for RS. In a cohort of RS patients, we studied the clinical utility of the eight reported prognostic classification systems for BM by assessing the aforementioned characteristics for clinical utility.

\section{MATERIALS AND METHODS}

The VUmc institutional database contains baseline characteristics, treatment details and follow-up data of newly diagnosed BM patients treated with Linac-based RS. At our 
center, patients with 1-3 BM diagnosed on high resolution contrast-enhanced MRI scans are eligible for RS as a single modality. RS has been delivered using 5 dynamic conformal arcs on a Novalis (2002-2008) or Novalis TX (2008 onwards) linear accelerator. Patient fixation was performed using the relocatable Gill-Thomas-Cosman frame, and as of 2008 using the BrainLAB's frameless mask system [BrainLAB, Feldkirchen, Germany]. RS was prescribed using a 'risk-adapted' fractionation, with lesions $\leq 7.5 \mathrm{~cm}^{3}$ receiving $21 \mathrm{~Gy}$ prescribed at the encompassing $80 \%$ isodose line. The RS target volumes consisted of the gross target volume contoured on the planning MRI with a $1 \mathrm{~mm}$ margin to correct for potential setup-inaccuracies. For lesions measuring $7.5-25 \mathrm{~cm}^{3}$ or $\mathrm{BM}$ that were adjacent to the brainstem, the prescription dose was lowered to $18 \mathrm{~Gy}$ at the $80 \%$ isodose. For the largest lesions with volumes exceeding $25 \mathrm{~cm}^{3}$, a single fraction of $15 \mathrm{~Gy}$ or 3 fractions of $8 \mathrm{~Gy}$, both prescribed at the $80 \%$ isodose was used.

Between December 2002 and July 2011, a total of 380 patients with 536 newly diagnosed BM were treated with Linac-based RS. The most relevant baseline characteristics are summarized in Table 2. Briefly, the median age of the patient group was 61 years, with the majority of patients (58\%) having primary lung cancer. Sixty-four percent of patients underwent RS for a single BM, 30\% for two lesions and only $6 \%$ of patients underwent RS for 3 lesions. Follow-up consisted of 3-monthly clinic visits with contrastenhanced MRI during the first year, followed by 6 -monthly MRI scans during the second year, and yearly thereafter. Survival was calculated from the date of RS. The median follow-up duration calculated using the reverse Kaplan-Meier method was 32 months.

Table 2 Baseline characteristics of study population $(n=380)$

\begin{tabular}{ll}
\hline Number of patients & $N=380$ (Dec '02-July'11) \\
\hline Gender & $202(53 \%)$ \\
Female & $178(47 \%)$ \\
Male & \\
WHO performance score & $310(82 \%)$ \\
$0-1$ & $70(18 \%)$ \\
$2-4$ & 61 years (16-89 years) \\
Median age (range) & \\
Primary tumor site & $220(58 \%)$ \\
Lung cancer & $40(11 \%)$ \\
Breast cancer & $30(8 \%)$ \\
Colorectal cancer & $27(7 \%)$ \\
Renal cell cancer & $24(6 \%)$ \\
Melanoma & $34(9 \%)$ \\
Other & $5(1 \%)$ \\
Unknown primary & \\
\hline
\end{tabular}




\begin{tabular}{|c|c|}
\hline Number of patients & $N=380$ (Dec'02-July'11) \\
\hline \multicolumn{2}{|l|}{ Primary tumor active } \\
\hline No & $204(54 \%)$ \\
\hline Yes & $176(46 \%)$ \\
\hline \multicolumn{2}{|l|}{ Extracranial metastases } \\
\hline No & $204(54 \%)$ \\
\hline Yes & $176(46 \%)$ \\
\hline Median interval primary tumor - BM (range) & 1 month (range $0-28$ months) \\
\hline \multicolumn{2}{|l|}{ Response to steroid treatment } \\
\hline Good/no steroids needed & $254(67 \%)$ \\
\hline Moderate/little response & $93(24 \%)$ \\
\hline Unknown & $33(9 \%)$ \\
\hline \multicolumn{2}{|l|}{ Number BM } \\
\hline 1 & $245(64 \%)$ \\
\hline 2 & $114(30 \%)$ \\
\hline 3 & $21(6 \%)$ \\
\hline Median volume largest BM (range) & $5.7 \mathrm{cc}$ (range $0.1-44.7 \mathrm{~cm}^{3}$ ) \\
\hline Median total volume treated BM (range) & $6.2 \mathrm{cc}$ (range $\left.0.1-44.7 \mathrm{~cm}^{3}\right)$ \\
\hline Median size largest BM diameter & $24 \mathrm{~mm}$ (range 3-50 mm) \\
\hline \multicolumn{2}{|l|}{ RS dose largest BM } \\
\hline $21 \mathrm{~Gy}$ & $176(46 \%)$ \\
\hline $18 \mathrm{~Gy}$ & $136(36 \%)$ \\
\hline $15 \mathrm{~Gy}$ & $25(7 \%)$ \\
\hline $8 \mathrm{~Gy}(3 \mathrm{X})$ & $43(11 \%)$ \\
\hline
\end{tabular}

Univariable Log-rank test and multivariable Cox regression analysis was used to determine risk factors for death for the baseline clinical variables. From the collected baseline characteristics, individual scores for all prognostic classification systems were calculated, i.e. the RPA, Rotterdam score, SIR, BSBM, GPA, DS-GPA, Rades score, and GGS. The distribution of patients within the separate prognostic classes was evaluated, and the prognostic value for the different classification systems for survival was determined using Kaplan-Meier analysis. The ability of the different prognostic classification systems to identify patients at high risk of early death following RS was evaluated by determining the sensitivity and specificity of the most unfavorable subclasses for predicting death within 3 months. Conversely, for assessing the ability to identify patients with long-term survival ( $\geq 12$ months), the sensitivity and specificity of the most favorable classes for predicting 12-month survival were calculated. The 3- and 12 month cut-off values for these analyses have been arbitrarily selected, as more validated definitions of good- and poor prognosis patient outcomes are currently lacking. 


\section{RESULTS}

The distribution of patients within the various prognostic classification systems is shown in Fig. 1. The group size within the intermediate RPA class was 64\%. All other prognostic classification systems showed similar proportions of patients within the intermediate group(s), ranging from $48 \%$ to $77 \%$. By definition, the four-tiered BSBM, GPA, and DSGPA have two intermediate groups. The proportion of patients in the most favorable class ranged from only $5 \%$ (GPA) to $49 \%$ (Rades), while the proportion of patients in the most unfavorable class ranged from 3\% (Rades) to 19\% (GPA).

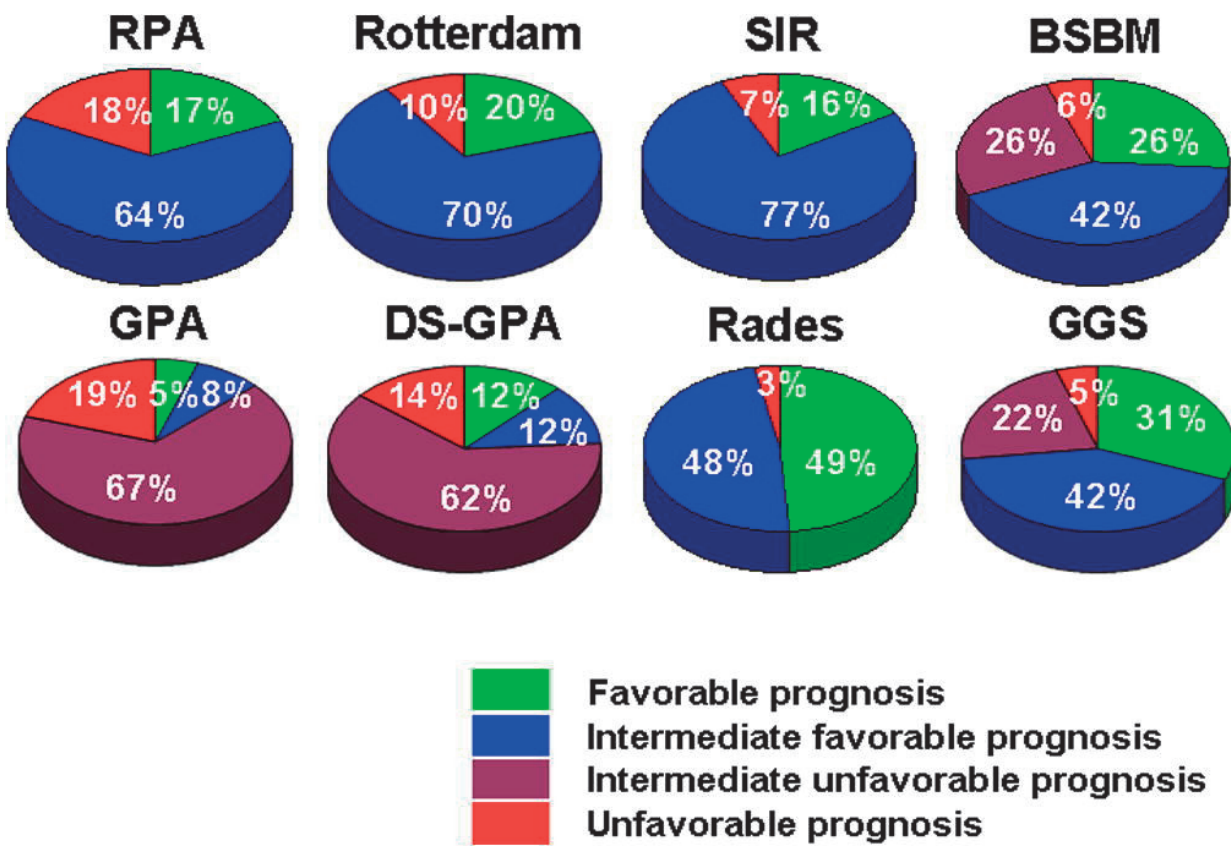

Figure 1 Distribution of patients in eight prognostic scoring systems

The median overall survival (OS) was 7.7 months, with OS rates of $76 \%, 57 \%$ and $39 \%$ at 3-, 6- and 12 months, respectively. Univariable analysis for baseline characteristics showed several factors to be correlated with better OS. In multivariable analysis, better performance status $(p=0.014)$, younger age $(p=0.008)$, primary breast $(p=0.003)$ and renal cell cancer $(p<0.001)$, female sex $(p=0.042)$, absence of extracranial metastases $(p<0.001)$ and a good response to steroid treatment $(p=0.040)$ or no clinical need for steroid treatment $(p=0.033)$ were correlated with significantly better OS. All eight investigated prognostic scoring systems were highly correlated with OS $(p<0.001)$ in univariable analysis, because of the high overlap between classification systems, these were not included in the multivariable analysis assessing individual factors. 
Chapter 2

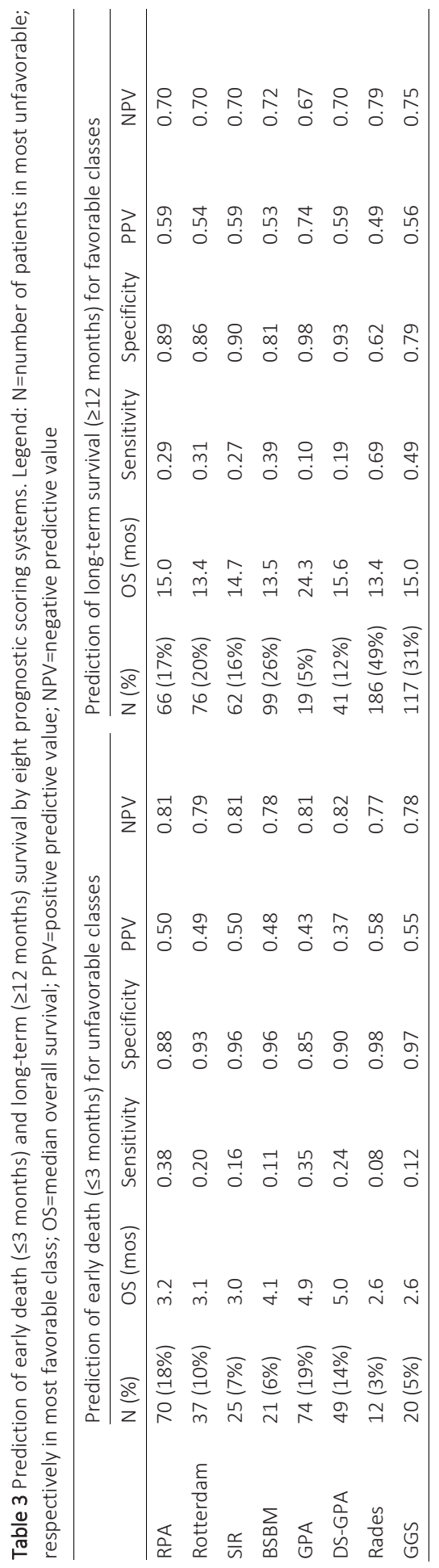


A total of 91 patients (24\%) of the entire population died within 3 months. The median survival in the most unfavorable groups of the different classification systems ranged from 2.6 to 5.0 months. The percentage of patients included in the most unfavorable prognostic groups dying within 3 months (i.e. positive predictive value) following RS varied between $37 \%$ (DS-GPA) and 58\% (Rades). The sensitivity and specificity of the unfavorable groups for predicting early death ranged from $8 \%$ (Rades) to 38\% (RPA) and 85\% (GPA) to 98\% (Rades), respectively (Table 3).

A total of 135 (39\%) patients of the entire population had a survival exceeding 12 months. The median survival in the most favorable groups ranged from 13.4 to 24.3 months in the eight prognostic scoring systems. The percentage of patients included in the most favorable prognostic groups, actually surviving more than 12 months (positive predictive value) following RS varied between 49\% (Rades) and 74\% (GPA). The sensitivity and specificity of the favorable groups for predicting long-term survival ranged from 10\% (GPA) to 69\% (Rades) and 62\% (Rades) to 98\% (GPA) (Table 3).

\section{DISCUSSION}

To our knowledge, this is the first study to systematically evaluate the predictive value of all currently known prognostic classification systems for BM in a homogeneous cohort of RS patients. In these patients treated with RS as a single modality the prognostic value of the well-known factors performance status, presence or absence of extracranial metastases and age were confirmed. In addition, primary tumor site, sex, and response to treatment with steroids were independent prognostic factors for survival. The multitude of independent prognostic factors [17] underscores the need for a relatively simple prognostic scoring system to aid clinicians in decision making. The RPA, originally described in 1997 by Gaspar et al., remains the most commonly used scoring system; however, it has been criticized because of the large proportion of patients included in the intermediate groups, limiting its use in clinical practice. In recent years several alternative scoring systems have been described, but it remains unclear whether these perform actually better than the RPA [9]. Similar to what has been previously reported, almost two thirds of our patients in this RS cohort were classified in the intermediate RPA class II. However, all other classification systems also suffered from the limitation of an unbalanced proportion of patients within prognostic classes (Fig. 2).

All scoring systems were highly predictive for survival, and the survival data are in good agreement with previously reported series. In clinical practice it may be useful to identify patients who are likely to have short survival as this could avert overtreatment with unjustified patient burden and health economic costs. The patient numbers in the unfavorable groups were relatively small for all scoring systems with a median OS ranging 
from 2.6 to 5.0 months. As patients in very poor condition or with fast progressive extracranial disease are not considered candidates for RS at our center, the unfavorable study patients constitute a sub-selection which may explain the relatively low sensitivity for predicting early death in the unfavorable groups. However, it may be even more important not to exclude patients from RS as a result of an incorrect prediction of early death. In regard of the latter, a high specificity (i.e. a low false positive rate) of the unfavorable classes in predicting early death may be considered the most valuable outcome measure. This specificity for predicting early death was high for all scoring systems, ranging from $85 \%$ to $98 \%$, which is comparable the specificity rates reported previously by Nieder et al. [18].

RPA
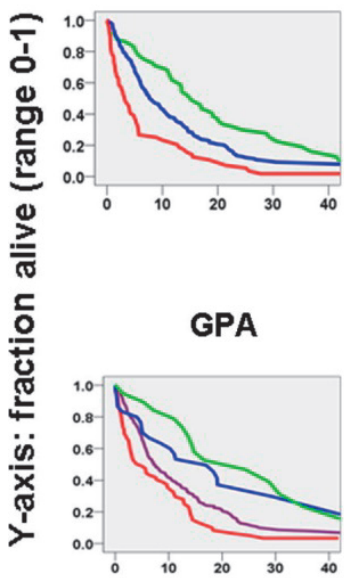

Rotterdam

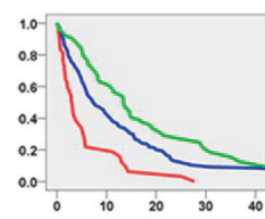

DS-GPA

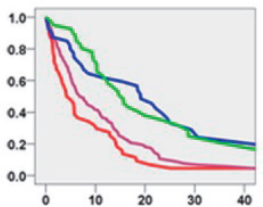

SIR

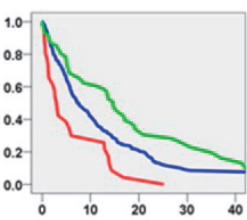

Rades

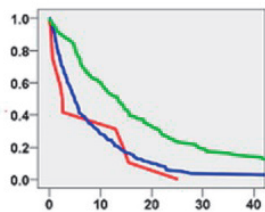

BSBM

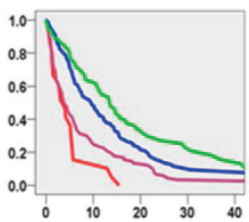

GGS

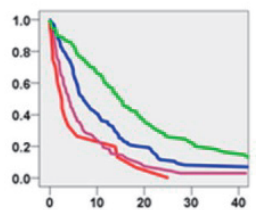

$\mathrm{X}$-axis: time from SRS (range 0-40 months)

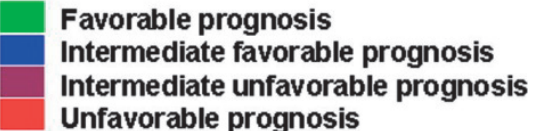

Figure 2 Overall survival for eight prognostic scoring systems

Similarly, it is important to identify patients who are likely to have long-term survival and may therefore be potential candidates for more aggressive intracranial- and extracranial treatment. Patients in the most favorable classes of the tested scoring systems had a 12 -month survival rate between $49 \%$ and $74 \%$. However, as a result of the varying proportions of patients included in these most favorite classes, the sensitivity for predicting 1 year survival ranged significantly from $10 \%$ to $69 \%$, in comparison to $29 \%$ for the RPA system.

It remains difficult to draw firm conclusions as to which classification system performs overall best based on the available data and analysis. All systems shared the limitation 
of an unbalanced proportion of patients within prognostic classes and all were highly correlated with overall survival. As was found in a recent review, the Rades, and GGS scores generally correlated best with the most relevant clinical endpoints of early death and long term survival, but the benefits of these scoring systems were modest [19]. In the absence of information that clearly demonstrates superiority, it seems preferable to retain the most widely used and relatively simple RPA classification system. Yamamoto's suggestion to further subdivide the intermediate RPA class II based on performance score, primary tumor control, extracranial metastases and number of BM [20] adds to the complexity of the RPA system. The application of this modified RPA resulted in a balanced distribution of RS patients within the five subgroups, and the survival curves of these subgroups were significantly separated (Supplementary Table online available). However, just as was the case for the newer four-tiered prognostic scoring systems such as the BSBM, GPA, DS-GPA, and GGS, this does not improve the identification of poor- respectively long prognosis patients.

The limitations of this retrospective study include the relatively low number of patients in comparison with the original reports of other various classification systems [5], [10], [13], [14] and [15], which most often included more than 1000 patients. Secondly, the pre-selection of patients suitable for RS explains the relatively small proportion of patients in the poor prognosis classes, and the results of our study cannot be extrapolated to all BM patients.

Supplementary table Modified RPA classification according to Yamamoto et al.(20) Legend: N=number of patients; OS=median overall survival

\begin{tabular}{lllll}
\hline RPA group & N (\% of all 380 pts) & OS (months) & Death $\leq 3$ months & Survival $\geq 12$ months \\
\hline I (favorable) & $66(17 \%)$ & 15.0 & $12 \%$ & $60 \%$ \\
Ila & $50(13 \%)$ & 10.2 & $10 \%$ & $41 \%$ \\
IIb & $102(27 \%)$ & 8.1 & $14 \%$ & $42 \%$ \\
IIC & $92(24 \%)$ & 5.7 & $34 \%$ & $29 \%$ \\
III (unfavorable) & $70(18 \%)$ & 3.2 & $47 \%$ & $20 \%$ \\
\hline
\end{tabular}

In conclusion, all eight prognostic scoring systems correlated very well with os but shared the limitation of an unbalanced proportion of patients within prognostic classes. As the clinical superiority of more recently developed prognostic scoring systems was modest, the well-known and easy to use RPA system currently remains the standard for patients with BM treated with RS. 


\section{REFERENCES}

[1] R. Wiggenraad, K.A. Verbeek-de, H.B. Kal, et al. Dose-effect relation in stereotactic radiotherapy for brain metastases. A systematic review. Radiother Oncol, 98 (2011), pp. 292-297

[2] A. Assouline, A. Levy, C. Chargari, et al. Whole brain radiotherapy: prognostic factors and results of a radiation boost delivered through a conventional linear accelerator. Radiother Oncol, 99 (2011), pp. 214-217.

[3] J.C. Flickinger, D. Kondziolka, L.D. Lunsford, et al. A multi-institutional experience with stereotactic radiosurgery for solitary brain metastasis. Int J Radiat Oncol Biol Phys, 28 (1994), pp. 797-802

[4] D. Kondziolka, A. Patel, L.D. Lunsford, A. Kassam, J.C. Flickinger. Stereotactic radiosurgery plus whole brain radiotherapy versus radiotherapy alone for patients with multiple brain metastases. Int J Radiat Oncol Biol Phys, 45 (1999), pp. 427-434.

[5] L. Gaspar, C. Scott, M. Rotman, et al. Recursive partitioning analysis (RPA) of prognostic factors in three Radiation Therapy Oncology Group (RTOG) brain metastases trials. Int J Radiat Oncol Biol Phys, 37 (1997), pp. 745-751

[6] M.A. Chidel, J.H. Suh, C.A. Reddy, et al. Application of recursive partitioning analysis and evaluation of the use of whole brain radiation among patients treated with stereotactic radiosurgery for newly diagnosed brain metastases. Int J Radiat Oncol Biol Phys, 47 (2000), pp. 993-999

[7] S.N. Sanghavi, S.S. Miranpuri, R. Chappell, et al. Radiosurgery for patients with brain metastases: a multiinstitutional analysis, stratified by the RTOG recursive partitioning analysis method. Int J Radiat Oncol Biol Phys, 51 (2001), pp. 426-434

[8] O. Agboola, B. Benoit, P. Cross, et al. Prognostic factors derived from recursive partition analysis (RPA) of Radiation Therapy Oncology Group (RTOG) brain metastases trials applied to surgically resected and irradiated brain metastatic cases. Int J Radiat Oncol Biol Phys, 42 (1998), pp. 155-159.

[9] C. Nieder, M.P. Mehta. Prognostic indices for brain metastases - usefulness and challenges. Radiat Oncol, 4 (2009), p. 10

[10] F.J. Lagerwaard, P.C. Levendag, P.J. Nowak, et al. Identification of prognostic factors in patients with brain metastases: a review of 1292 patients. Int J Radiat Oncol Biol Phys, 43 (1999), pp. 795-803

[11] E. Weltman, J.V. Salvajoli, R.A. Brandt, et al. Radiosurgery for brain metastases: a score index for predicting prognosis. Int J Radiat Oncol Biol Phys, 46 (2000), pp. 1155-1161.

[12] J. Lorenzoni, D. Devriendt, N. Massager, et al. Radiosurgery for treatment of brain metastases: estimation of patient eligibility using three stratification systems. Int J Radiat Oncol Biol Phys, 60 (2004), pp. 218-224

[13] P.W. Sperduto, B. Berkey, L.E. Gaspar, M. Mehta, W. Curran. A new prognostic index and comparison to three other indices for patients with brain metastases: an analysis of 1,960 patients in the RTOG database. Int J Radiat Oncol Biol Phys, 70 (2008), pp. 510-514

[14] P.W. Sperduto, S.T. Chao, P.K. Sneed, et al. Diagnosis-specific prognostic factors, indexes, and treatment outcomes for patients with newly diagnosed brain metastases: a multi-institutional analysis of 4,259 patients. Int J Radiat Oncol Biol Phys, 77 (2010), pp. 655-661

[15] D. Rades, L. Dziggel, T. Haatanen, et al. Scoring systems to estimate intracerebral control and survival rates of patients irradiated for brain metastases. Int J Radiat Oncol Biol Phys, 80 (2011), pp. 1122-1127

[16] D.W. Golden, K.R. Lamborn, M.W. McDermott, et al. Prognostic factors and grading systems for overall survival in patients treated with radiosurgery for brain metastases: variation by primary site. J Neurosurg, 109 (2008), pp. 77-86

[17] M. Sen, A.S. Demiral, R. Cetingoz, et al. Prognostic factors in lung cancer with brain metastasis. Radiother Oncol, 46 (1998), pp. 33-38

[18] C. Nieder, A. Pawinski, M. Molls. Prediction of short survival in patients with brain metastases based on three different scores: a role for 'triple-negative' status? Clin Oncol (R Coll Radiol), 22 (2010), pp. 65-69

[19] Rodrigues G, Bauman G, Palma D, et al. Systematic review of brain metastases prognostic indices. Pract Radiat Oncol, in press.

[20] M. Yamamoto, Y. Sato, T. Serizawa, et al. Subclassification of recursive partitioning analysis class II patients with brain metastases treated radiosurgically. Int J Radiat Oncol Biol Phys, 83 (2012), pp. 1399-1405 
Chapter

\section{Recursive Partitioning Analysis for the Prediction of Stereotactic Radiosurgery Brain Metastases Lesion Control}

The Oncologist 2013;18(3):330-5

Rodrigues G, Zindler JD, Warner A, Lagerwaard FJ. 


\section{ABSTRACT}

Purpose. The objective of this investigation was to identify independent pretreatment factors that predict for control of local brain metastases (BM) in a large singleinstitution series of patients receiving stereotactic radiosurgery (SRS). Recursive partitioning analysis was used to potentially identify a class of patients with durable lesion control characteristics.

Methods. A retrospective SRS database containing baseline characteristics, treatment details, and follow-up data of newly diagnosed patients with 1-3 BM (on magnetic resonance imaging) treated with linear accelerator-based SRS was created. Three study endpoints were used: time to progression (primary endpoint, individual lesion progression; $n$ 536), time to first progression (secondary endpoint, first lesion progression on an individual patient basis; $n$ 380), and overall survival (secondary endpoint; $n$ 380). Recursive partitioning analysis (RPA) was performed to identify predictors of time to progression. Results. Multivariable analysis demonstrated that lesion aspect/ phenotype and radiotherapy schedule were independent factors associated with both progression outcomes. Presence of tumor necrosis was found to be associated with a significant hazard of progression (hazard ratio 3), whereas use of the most intense radiotherapy fractionation schedule (21 Gy in one fraction) was associated with significant reductions in progression (hazard ratio 0.3). RPA using SRS dose and lesion aspect/phenotype was created and described three distinct prognostic groups.

Conclusions. RPA of a large retrospective database of patients receiving SRS confirmed previous observations regarding the importance of SRS dose and lesion aspect/ phenotype in lesion control and overall survival. The SRS lesion analysis may help to stratify future clinical trials and better define patient care options and prognosis. 


\section{IMPLICATIONS FOR PRACTICE}

The importance of this work is primarily in the confirmation of previously reported associations between lesion dose and MRI phenotype with local lesion control after stereotactic radiosurgery. This manuscript extends these associations into a clinical useful risk stratification system to relate how lesion dose and MRI phenotype can relate to lesion control and overall survival. This new risk stratification system may assist in clinical care and clinical trial design by better defining expected treatment outcomes after stereotactic radiosurgery.

\section{INTRODUCTION}

The diagnosis of brain metastases (BM) is frequently related to the natural history of the spread of many primary tumors, including those arising in the lung, breast, colorectal, renal, and skin (i.e., melanoma) [1]. Development of metastatic disease in the brain can lead to clinically significant reductions in health-related quality of life, neurologi$\mathrm{cal} /$ neurocognitive compromise, and life expectancy [2]. Treatment selection is highly dependent on pretreatment clinical factors, prognosis (as estimated by various published risk stratification prognostic indices), and patient treatment preferences $[3,4]$.

A published randomized controlled trial (RCT) comparing whole brain radiotherapy (WBRT) plus stereotactic radiotherapy (SRS) boost versus WBRT alone supported the use of the SRS technique in oligometastatic (1-3 brain metastases $\leq 3.0 \mathrm{~cm}$ ) patients [5]. This clinical trial demonstrated clinically important improvements in lesion control, performance status, and survival (in the solitary metastasis subgroup). Subsequent published RCTs have addressed the issue of whether or not the WBRT component is advisable for the initial treatment of de novo brain metastases [6-9]. In general, inclusion of WBRT has been shown to improve regional intracranial control but at the expense of additional neurocognitive effects.

Durable lesion control, ideally lasting during the expected patient lifespan, is an important goal of high-quality SRS to prevent symptomatic recurrence that would mandate consideration of one or more salvage procedures including WBRT, neurosurgical resection, and various forms of drug therapy [10]. Various investigations have been published on the topic of predictive factors associated with lesion control in the context of SRS treatment [11-18]. Factors that have been shown in at least one publication to be a significant predictor of lesion control include lesion dose, lesion radiological characteristics (i.e., lesion aspect), lesion target volume, patient performance status, presence of extracranial disease, cancer histology, and inclusion of WBRT. 
The objective of this investigation is to identify independent pretreatment factors that predict for lesion control in the context of a large single-institution series of SRS for brain metastases. Recursive partitioning analysis was used to potentially identify a class of patients with durable lesion control characteristics. Our findings are discussed in the context of previously published investigations.

\section{METHODS}

The SRS database contains baseline characteristics, treatment details, and follow-up data of patients who were newly diagnosed with BM and treated with linear accelerator (LINAC)-based SRS. Patients with 1-3 newly diagnosed BM (including those near the brainstem and posterior fossa) that were confirmed on high-resolution contrastenhanced magnetic resonance imaging (MRI) were eligible for single-modality SRS. Patients with recurrent disease after previous radiotherapy were not included in this series.

SRS was delivered using five dynamic conformal arcs either on a Novalis linear accelerator (2002-2008) or a Novalis TX linear accelerator (2008 onwards; BrainLAB, Feldkirchen, Germany). Patient fixation was performed using the relocatable Gill-ThomasCosman frame (2002-2008) or with BrainLAB's frameless mask system (2008 onwards; BrainLAB, Feldkirchen, Germany).

The SRS target volumes consisted of the outer contrast-enhancing border of the lesions contoured on the planning MRI with a 1-mm margin to correct for residual setup error. All lesion target volumes were prescribed to the $80 \%$ isodose line. SRS was generally prescribed using a prospectively defined risk-adapted fractionation scheme, with the smallest lesions $\left(\leq 7.5 \mathrm{~cm}^{3}\right)$ receiving $21 \mathrm{~Gy}$, lesions measuring $7.5-25 \mathrm{~cm}^{3}$ or those BM adjacent to the brainstem receiving $18 \mathrm{~Gy}$, and the largest lesions $\left(>25 \mathrm{~cm}^{3}\right.$ ) receiving either a single fraction of 15 Gy or $24 \mathrm{~Gy}$ in three fractions of $8 \mathrm{~Gy}$. The prescription dose was always determined after contouring the target volume in the planning system. Because brain metastases are often spherical, the 21-Gy cutoff value generally corresponds to lesions with a maximum diameter of approximately $2.5 \mathrm{~cm}$; the 18-Gy cutoff value corresponds to lesions of approximately $3.6 \mathrm{~cm}$.

The recommended follow-up for patients receiving SRS consisted of clinic visits including neurological examination with contrast-enhanced MRI every 3 months during the first 2 years, followed by clinic visits and MRI scans every 6 months thereafter. The median follow-up duration of the database calculated using the reverse Kaplan-Meier method was 32 months [19].

Lesional aspect was classified based on the pattern of contrast enhancement on gadolinium-enhanced T1 sequences of the MRI, as was previously described by Goodman et 
al. [18]. Lesions were classified as follows: (a) lesions with homogeneous (i.e., uniform) contrast enhancement; (b) lesions with heterogeneous contrast enhancement, if there were areas of nonhomogeneous contrast enhancement; (c) thin-walled cystic lesions (either simple cystic or multicystic); and (d) lesions with a necrotic center. Radiological evidence of lesional progressive disease was defined according to the criteria described by Shiau et al. [17] and specifically was defined as "at least $25 \%$ increase in the product of three perpendicular diameters (craniocaudal, anterior-posterior, and mediolateral)". Date of death and intracranial and extracranial disease status at time of death was also captured in the retrospective database.

\section{Endpoints}

Three separate endpoints were used in conjunction with this predictive analysis. Time to progression ( $n=536$ lesions) was the primary endpoint, defined as time from initiation of stereotactic radiosurgery to development of progressive disease on a per-lesion level. Each lesion was evaluated according to the previously described follow-up guidelines to determine whether or not radiological and/or clinical evidence of progressive disease was indeed present (yes/no) as well as the date of evaluation.

Time to first progression ( $n=380$ patients) was one of the secondary endpoints. This endpoint was derived from the time-to-progression endpoint at a per-patient level. Patients were first evaluated as having either progressive intracranial disease at any lesion/site (yes/no), then further evaluated to determine in which lesion(s) progression first occurred. If two or three lesions showed progression at same time, the largest lesion was used in the final analysis [20]. This analysis was performed to further assess the stability of findings from the primary analysis of time to progression (per lesion) in terms of possible nonindependence issues resulting from the inclusion of more than one lesion per patient.

Survival ( $n=380$ patients) was used as the other secondary endpoint. Survival was defined as time from initiation of stereotactic radiosurgery to date of last follow-up and/or death, whichever came first. This endpoint was reported for descriptive purposes only and was not used for any predictive modeling.

\section{Statistical Methodology}

Univariable Cox regressions were constructed for time to progression (model 1) and time to first progression (model 2) to identify significant predictors of progressive disease; they were performed at the lesion level $(n=536)$ and patient level $(n=380)$, respectively. Multivariable Cox regression analyses were performed, incorporating all factors found to be somewhat significant from univariable Cox regression (i.e., p < .30), followed by automated backward elimination technique to sequentially remove factors 
until all remaining covariates had $p$ values less than .15. Adjustment for clustering was performed for univariable and multivariable analyses related to time to progression due to the fact that each patient contributed different numbers of lesions to the analysis.

Recursive partitioning analysis (RPA) was performed at the lesion level ( $n=536)$, incorporating significant predictors identified from multivariable Cox regression (model 1 factors: lesion radiological phenotype [aspect] and radiation dose) [21]. The SRS lesion RPA was performed in two ways: (a) primarily as a time-to-event outcome (taking into account time to progressive disease) and (b) modeling progressive disease as a binary outcome (yes/no) to assess the robustness of the SRS lesion RPA model created. KaplanMeier estimates of time to progression $(n=536)$ and time to first progression $(n=380)$ were performed. Kaplan-Meier estimates stratified by baseline characteristics and proposed SRS lesion RPA stratifications were also calculated (for all three endpoints including overall survival) and different classes were compared using log-rank test statistic. Statistical analysis was performed using SAS (version 9.2; SAS Institute, Cary, NC) and the open-source R software platform (www.r-project.org).

\section{RESULTS}

Between December 2002 and July 2011, a total of 380 patients with 536 newly diagnosed BM were treated with LINAC-based SRS as a single modality. Patient, tumor, and treatment-related descriptive statistics organized per patient $(n=380)$ and per lesion ( $n$ = 536) are summarized in Table 1. A variety of dose fractionation schedules were used for the 536 lesions treated: 21 Gy in one fraction (292 lesions, 54.5\%), 18 Gy in one fraction (170 lesions, 31.7\%), 24 Gy in three fractions (47 lesions, 8.8\%), and 15 Gy in one fraction (27 lesions, 5.0\%). Progressive disease was identified in 71 of 536 lesions $(13 \%)$ in 65 of 380 patients (17\%). Fifty-five patients (15\%) were alive at last follow-up.

Table 1 Baseline characteristics of patients and lesions

\begin{tabular}{lcc}
\hline Characteristic & Patients $(\boldsymbol{n}=\mathbf{3 8 0})^{\mathbf{a}}$ & Lesions $(\boldsymbol{n}=\mathbf{5 3 6})$ \\
\hline Age & & \\
Mean \pm SD (yrs) & $61.15 \pm 11.57$ & $60.95 \pm 11.41$ \\
Median yrs (range) & $61.25(16.47-89.10)$ & $61.12(16.47-89.10)$ \\
Patients $\leq 55$ yrs, $n(\%)$ & $118(31.1)$ & $168(31.3)$ \\
$>55$ to $\leq 65$ yrs, $n(\%)$ & $120(31.6)$ & $173(32.3)$ \\
$>65$ to $\leq 75$ yrs, $n(\%)$ & $98(25.8)$ & $137(25.6)$ \\
$>75$ yrs, $n(\%)$ & $44(11.6)$ & $58(10.8)$ \\
Men, $n(\%)$ & $178(46.8)$ & $251(46.8)$ \\
Primary tumor, $n(\%)$ & & \\
Lung & $220(57.9)$ & $303(56.5)$ \\
Breast & $40(10.5)$ & $60(11.2)$ \\
Renal/adrenal & $27(7.1)$ & $48(9.0)$ \\
Colon & $30(7.9)$ & $37(6.9)$ \\
Melanoma & $24(6.3)$ & $33(6.2)$ \\
Other & $39(10.3)$ & $55(10.3)$ \\
\end{tabular}




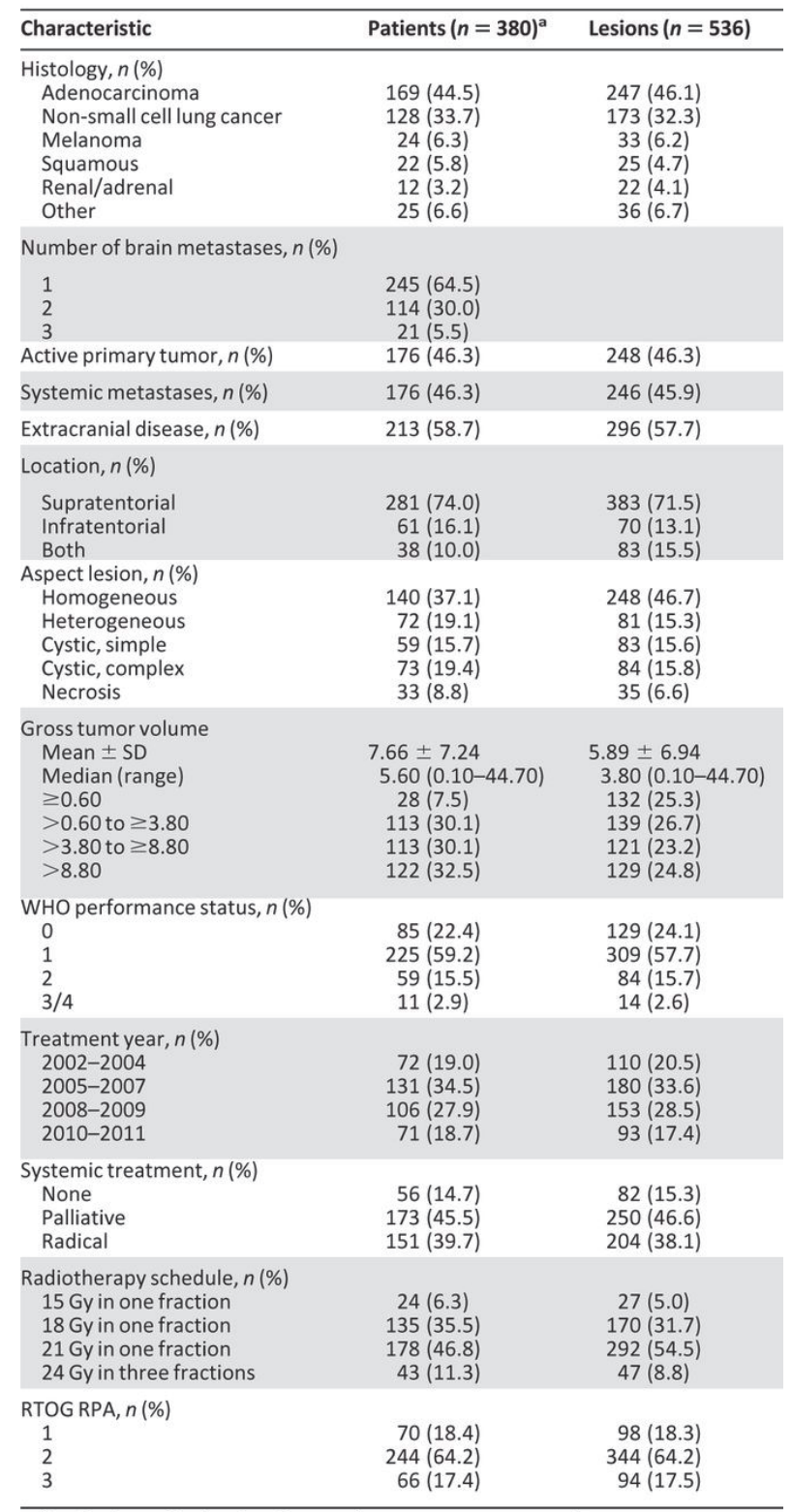

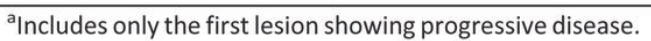

Abbreviations: RTOG RPA, Radiation Therapy Oncology Group recursive partitioning analysis; WHO, World Health Organization.

Results from the univariable Cox regression analysis for both the lesional (time to progression) and patient (time to first progression) analyses are depicted in Table 2. Results of multivariable Cox regression analysis for both time to progression and time to first progression are summarized in supplemental online Tables 1 and 2, respectively. Both 
models demonstrate that lesion aspect/phenotype and radiotherapy schedule are independent factors associated with both progression outcomes. Presence of tumor necrosis was found to be associated with a significant hazard of progression (hazard ratio >3), whereas use of the most intense radiotherapy fractionation schedule (21 Gy in one fraction) was associated with significant reductions in progression (hazard ratio <0.3).

Table 2 Univariable Cox regression models examining relationship between individual predictors of time to progression $(n=536)$ and time to first progression $(n=380)$

\section{$p$ value}

\begin{tabular}{lcl}
\cline { 2 - 3 } Variables & $\begin{array}{c}\text { Per lesion } \\
(\boldsymbol{n}=\mathbf{5 3 6})\end{array}$ & $\begin{array}{l}\text { Per patient } \\
(\boldsymbol{n}=\mathbf{3 8 0})\end{array}$ \\
\hline Age & .291 & .239 \\
Male & .605 & .442 \\
Primary tumor & .254 & .079 \\
Histology & .045 & .032 \\
Active primary tumor & .379 & .239 \\
Systemic metastases & .521 & .985 \\
Extracranial disease & .143 & .113 \\
Location & .635 & .690 \\
Aspect lesion & $<.001$ & .009 \\
Gross tumor volume & $<.001$ & .032 \\
WHO performance status & .659 & .885 \\
Treatment year & .010 & .029 \\
Radiotherapy Schedule & $<.001$ & .012 \\
Recursive partitioning analysis & .097 & .126 \\
BSBM & .426 & .529 \\
SIR group & .408 & .656 \\
GPA group & .370 & .545 \\
GGS group & .920 & .972 \\
RADES group & .738 & .744 \\
DSGPA group & .812 & .823 \\
RDAM & .917 & .961 \\
\hline p & & \\
\hline
\end{tabular}

$p$ values are reported from Wald Sandwich test. Values shown in italics were not incorporated in multivariable analysis.

Abbreviations: BSBM, Basic Score of Brain Metastases; DS, disease specific; GPA, Graded Prognostic Assessment; GGS, Golden Grading System; RADES, index developed by Rades et al. [22]; RDAM, Rotterdam Scale; SIR, Score Index for Radiosurgery; WHO, World Health Organization.

Kaplan-Meier curves for all eligible patients and subdivided into relevant groups for both progression outcomes are summarized in supplemental online Fig. 1. As depicted in Fig. 1, SRS lesion RPA time-to-event and binary analyses partitioned the patient popu- 
lation into four possible groupings based on radiotherapy schedule (21 Gy in one fraction vs. the other less intense regimens) and lesion aspect/phenotype (different combinations observed; however, the $21 \mathrm{~Gy} / 1$ fraction arm was split identically between homogeneous/heterogeneous vs. cystic/necrotic). Kaplan-Meier curves for each of the SRS lesion RPA groups were created for both progression outcomes using both RPA approaches (time to event and binary; Fig. 2).

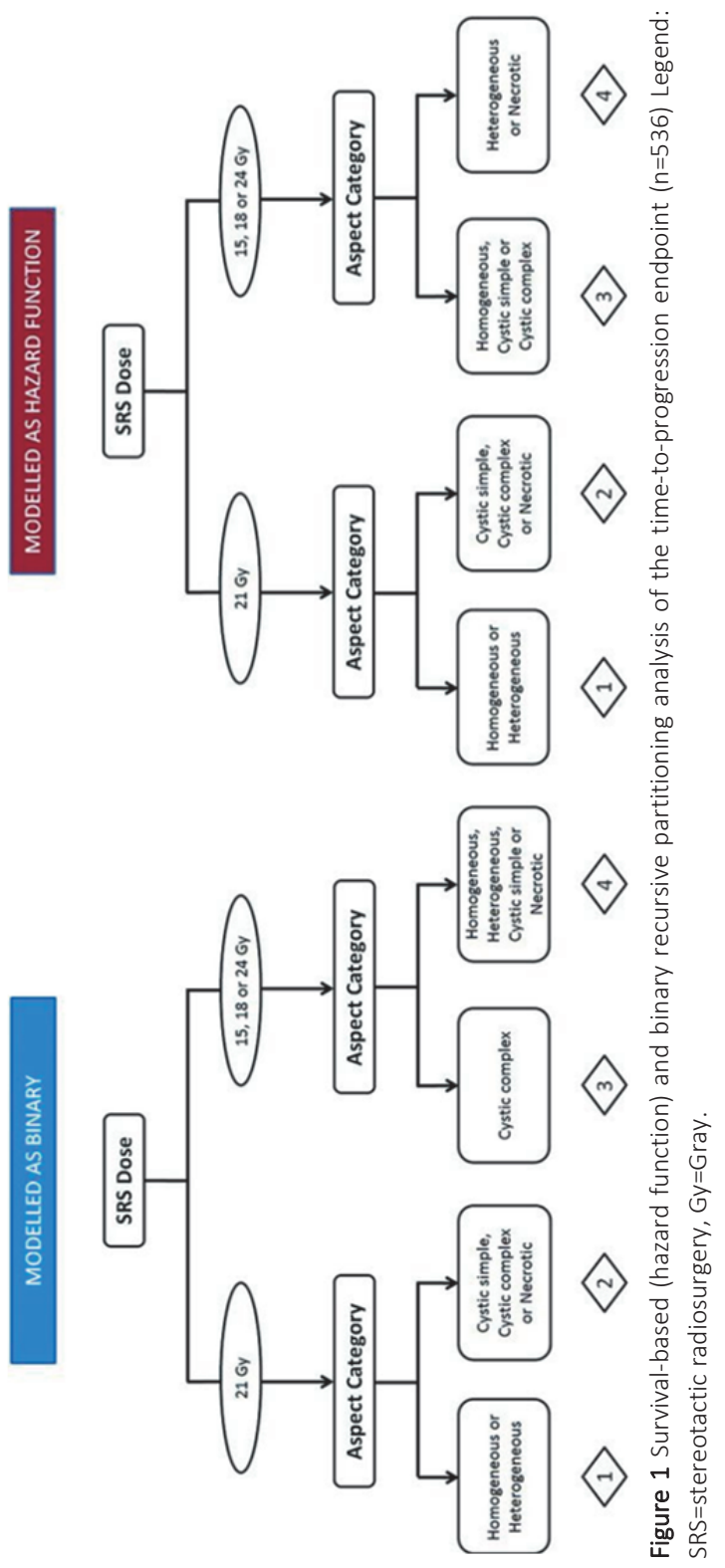


Inspection of these Kaplan-Meier depictions demonstrated that three distinct groups of patients were present: a good prognosis group (group 1), intermediate groups consisting of the two middle SRS lesion RPA groups (groups 2 and 3), and a poor prognosis group (group 4). Individual Kaplan-Meier progression curves for each aspect/phenotype combination with the $21 \mathrm{~Gy} / 1$ fraction schedule versus other fractionation schedules are shown in supplemental online Fig. 2. Supplemental online Fig. 3 summarizes the Kaplan-Meier overall survival curves for all patients and curves divided by lesion/aspect and highest radiation biological equivalent dose fractionation. Kaplan-Meier overall survival estimates were affected by the SRS lesion RPA group, with a statistically significant log-rank test $(p=.05)$ in terms of overall survival.

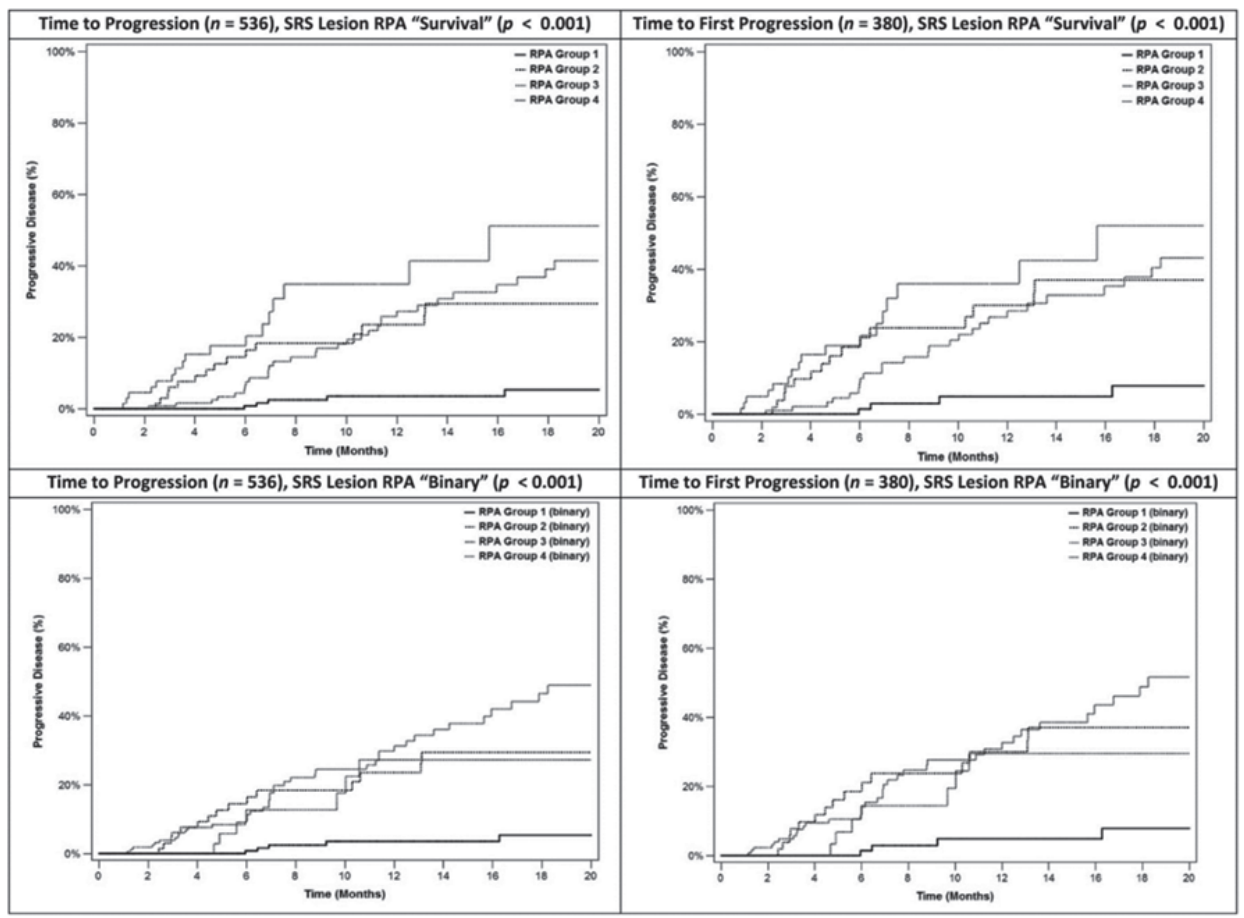

Figure 2 Time to progression ( $n=536)$ and time to first progression $(n=380)$ Kaplan-Meier curves for derived recursive partitioning classes. Legend: RPA, recursive partitioning analysis; SRS, stereotactic radiosurgery. Legend: RPA, recursive partitioning analysis; SRS, stereotactic radiosurgery

\section{DISCUSSION}

This study summarized the progression and survival outcomes of a large SRS database, with a particular focus on the determination of factors that predict for brain metastasis local lesion control. Lesion aspect/phenotype and radiation dose schedule were both found to be critical independent factors both in the prediction of time to lesion progres- 
sion and also time to first lesion progression at the patient level. The presence of extracranial disease was found to have a borderline significant effect on radiological confirmation of lesional progression. This may be due to a confounding effect in which patients with extracranial disease may suffer from extracranial progression and death prior to intracranial lesion progression. Regine et al. previously observed this relationship in a cohort of 36 patients in which presence of extracranial disease reduced the rate of observed symptomatic brain recurrence by more than half [13]. Tumor histology was not found to inform the SRS lesion RPA despite statistical significance on univariable analysis. It is hypothesized that, in the context of SRS dosing, histology may not be important given the ablative doses being used and/or that the prognostic impact of histology may be exerted indirectly through lesion phenotype (i.e., necrotic lesions) having inferior local control.

An RPA approach was used to further investigate the relationship between lesion aspect/phenotype and RT schedule with progression outcomes. This analysis demonstrated that three distinct groups exist that predict for time to progression, time to first progression, and overall survival. Specifically, this SRS lesion RPA has identified a highrisk subgroup of patients that potentially do not fully benefit from SRS therapy. This high-risk patient population may have been alternatively treated with whole brain radiotherapy alone, with the potential advantages of treatment simplicity and lower cost and/or resource expenditure (dependent on practice setting). However, it is important to note that identifying this high-risk patient population may lead to future treatment innovation research. The therapeutic ratio could be improved by optimization of dose escalation, dose targeting, treatment delivery, and novel drug therapy.

The three SRS lesion groups are summarized as follows:

1. Low progression risk: Homogeneous or heterogeneous lesion treated with $21 \mathrm{~Gy}$ in one fraction

2. Intermediate progression risk: Any cystic lesion treated between 15-21 Gy in one or $24 \mathrm{~Gy}$ in three fractions or necrotic lesions treated with $21 \mathrm{~Gy}$ in 1 fraction or homogeneous lesions treated with 15-18 Gy in one fraction or 24 Gy in three fractions

3. High progression risk: Heterogeneous or necrotic lesions treated with 15-18 Gy in one fraction or $24 \mathrm{~Gy}$ in three fractions

Shiau et al. previously reported the interaction of radiotherapy schedule and lesion aspect on lesion control [17]. In this retrospective series of 119 patients with 219 lesions treated with SRS from 1991-1994, patients were treated with a median SRS dose of 18.5 Gy (range: 10-22 Gy) with a median lesion size of $1.3 \mathrm{cc}$ (range: 0.02-30.9 cc). Multivariable Cox proportional hazards analysis demonstrated that SRS dose $\geq 18$ Gy, lesion aspect/phenotype, and interval between diagnosis and SRS therapy were independent predictors of freedom from progression. The authors suggest that SRS dose could be a surrogate for lesion dose; however, tumor volume was not found to be inde- 
pendently significant on multivariable analysis. Our analysis further demonstrated a correlation between SRS dose and lesion size and identified SRS dose as the independent predictor of progression over lesion size.

Other investigators have studied the interaction of SRS dose, lesion size, and various patient outcomes $[11,12,14]$. Breneman et al. published a predictive analysis of 84 patients and 145 lesions, which observed that patients receiving SRS dose $\geq 18$ Gy and/or melanoma histology had improved local control. Similarily, Schomas et al. [14] observed that dose prescription, minimum tumor dose, histology, and tumor volume were predictive of local control on univariable analysis. Minimum tumor dose was the only factor predictive of local control on multivariable analysis $(p=.03)$.

Molenaar et al. also observed that SRS dose, planning target volume, and patient performance status were predictive of time to local failure [12]. Shetata et al. suggested that the use of whole-brain radiation therapy in conjunction with SRS improved lesion control [15]; however, this claim has not been reported elsewhere in literature. A systematic review formally exploring the relationship between dose and local control was conducted by Wiggenraad et al. [16]. This review assessed 11 papers and demonstrated that 6-month local control was greater than $80 \%$ irrespective of SRS dose fractionation schedule. One-year local control rates with single-dose SRS treatment were observed to be more variable and depended on dose: $>80 \%$ for $\geq 21 \mathrm{~Gy}$ ), $>60 \%$ for $\geq 18 \mathrm{~Gy}$ ), and $<50 \%$ for $<15$ Gy.

The major limitation of this work is that the database is derived from a retrospective analysis of patients who received SRS. Mitigating the issue of the retrospective nature of the database was the prospective approach regarding patient selection, treatment simulation/delivery, dose-fractionation selection, and follow-up procedures relating to this patient population. Future work in this area will include validation of our findings in other existing SRS databases. Additionally, modeling of regional (out-of-field) failure risk may provide insight into patients better served with the integration of whole-brain radiation therapy in conjunction with SRS therapy.

\section{CONCLUSIONS}

A recursive partitioning analysis of a large retrospective SRS database has confirmed previous observations regarding the importance of SRS dose and lesion aspect/phenotype in lesion control. The SRS lesion RPA describes three distinct prognostic groups of patients in terms of time to lesion progression. Use of the SRS lesion RPA groups also predicted for overall survival using an actuarial log-rank test analysis. The SRS lesion RPA analysis may help to stratify future SRS clinical trials and better define patient care options and prognosis in conjunction with SRS therapy. 


\section{REFERENCES}

[1] Tsao MN, Lloyd N, Wong RK, et al. Whole brain radiotherapy for the treatment of newly diagnosed multiple brain metastases. Cochrane Database Syst Rev 2012;4:CD003869.

[2] Tsao MN, Lloyd NS, Wong RK et al. Radiotherapeutic management of brain metastases: A systematic review and meta-analysis. Cancer Treat Rev 2005;31:256-273.

[3] Nieder C, Mehta MP. Prognostic indices for brain metastases: Usefulness and challenges. Radiat Oncol 2009;4:10.

[4] Tsao MN, Rades D, Wirth A, et al. Radiotherapeutic and surgical management for newly diagnosed brain metastasis(es): An American Society for Radiation Oncology evidence-based guideline. Pract Radiat Oncol $2012 ; 2: 210-225$.

[5] AndrewsDW,Scott CB, SperdutoPWet al. Whole brain radiation therapy with or without stereotactic radiosurgery boost for patients with one to three brain metastases: Phase III results of the RTOG 9508 randomised trial. Lancet 2004;363:1665-1672.

[6] Kocher M, Soffietti R, Abacioglu U et al. Adjuvant whole-brain radiotherapy versus observation after radiosurgery or surgical resection of one to three cerebral metastases: Results of the EORTC 2295226001 study. J Clin Oncol 2011;29:134 -141.

[7] Aoyama H, Shirato H, TagoMet al. Stereotactic radiosurgery plus whole-brain radiation therapy vs. stereotactic radiosurgery alone for treatment of brain metastases: A randomized controlled trial. JAMA 2006;295:2483-2491.

[8] AoyamaH, TagoM,KatoNet al. Neurocognitive function of patients with brain metastasis who received either whole brain radiotherapy plus stereotactic radiosurgery or radiosurgery alone. Int J Radiat Oncol Biol Phys 2007;68:1388-1395.

[9] Chang EL, Wefel JS, Hess KR, et al. Neurocognition in patients with brain metastases treated with radiosurgery or radiosurgery plus whole-brain irradiation: A randomised controlled trial. Lancet Oncol 2009;10:1037-1044.

[10] LinskeyME,AndrewsDW,AsherALetal.Therole of stereotactic radiosurgery in the management of patients with newly diagnosed brain metastases: A systematic review and evidence-based clinical practice guideline. J Neurooncol 2010;96:45-68.

[11] Breneman JC, Warnick RE, Albright RE Jr. et al. Stereotactic radiosurgery for the treatment of brain metastases. Results of a single institution series. Cancer 1997;79:551-557.

[12] Molenaar R, Wiggenraad R, Verbeek-de Kanter A et al. Relationship between volume, dose and local control in stereotactic radiosurgery of brain metastasis. Br J Neurosurg 2009;23:170 -178.

[13] Regine WF, Huhn JL, Patchell RA et al. Risk of symptomatic brain tumor recurrence and neurologic deficit after radiosurgery alone in patients with newly diagnosed brain metastases: Results and implications. Int J Radiat Oncol Biol Phys 2002; 52:333-338.

[14] Schomas DA, Roeske JC, MacDonald RL et al. Predictors of tumor control in patients treated with LINACbased stereotactic radiosurgery for metastatic disease to the brain. Am J Clin Oncol 2005;28: 180-187.

[15] Shehata MK, Young B, Reid B, et al. Stereotatic radiosurgery of 468 brain metastases $2 \mathrm{~cm}$ : Implications for SRS dose and whole brain radiation therapy. Int J Radiat Oncol Biol Phys 2004; 59:87-93.

[16] Wiggenraad R, Verbeek-de Kanter A, Kal HB et al. Dose-effect relation in stereotactic radiotherapy for brain metastases. A systematic review. Radiother Oncol 2011;98:292-297.

[17] Shiau CY, Sneed PK, Shu HK et al. Radiosurgery for brain metastases: Relationship of dose and pattern of enhancement to local control. Int J Radiat Oncol Biol Phys 1997;37:375-383. 

Chapter

\begin{abstract}
A Clinical Nomogram and Recursive Partitioning Analysis to Determine the Risk of Regional Failure after Radiosurgery Alone for Brain Metastases
\end{abstract}

Radiother Oncol. 2014 Apr;111(1):52-8

Rodrigues G, Warner A, Zindler JD, Slotman BJ, Lagerwaard FJ. 


\section{ABSTRACT}

Purpose This investigation defined patient populations at high-, intermediate-, and lowrisk of regional failure (RF) after stereotactic radiosurgery (SRS) lesion treatment using clinical nomograms and recursive partitioning analysis (RPA).

Methods and materials We created a retrospective database compiling 361 oligometastatic brain metastases patients treated with single-modality Linac-based SRS. Logistic analysis was performed to identify factors to be included in a RPA to predict for cumulative RF at 1-year. A 1-year cumulative RF clinical nomogram was constructed and validated (c-index statistic).

Results Age, number of brain metastases, World Health Organization (WHO) performance status (PS), and maximum gross tumor volume (GTV) size were found to be statistically significant predictors of the primary outcome. RPA classifications were defined as follows: low-risk (<25\% 1-year RF): solitary lesion AND age $>55 Y$; intermediate-risk (25-40\% 1-year RF): age 65 years AND solitary lesion OR WHOP1 AND 2-3 lesions; and high-risk (>40\% 1-year RF): WHO PS $=0$ AND 2-3 lesions. These classifications were highly statistically significant $(p<0.01$ ) for RF. A clinical nomogram (containing patient age, lesion number, largest GTV volume, and WHO PS) for the prediction of 1-year cumulative RF was created (c-index 0.69).

Conclusion A risk-adapted treatment approach can be applied for BM radiosurgery either using RPA categories and/or nomogram-based risk estimates. 


\section{INTRODUCTION}

In patients with a limited number $(1-3)$ of small $(\leq 4.0 \mathrm{~cm})$ brain metastases (oligometastatic brain disease), the use of SRS with WBRT versus WBRT alone has been shown to be associated with improvements in various clinical outcomes including: lesion control, performance status, and survival (for the solitary brain metastasis sub-population) [1]. Clinical information on the comparison of SRS lesional treatment without WBRT suggests equivalent survival outcome with a potential improved survival for subpopulations of patients with superior prognostic factors (younger age, good performance status, lack of extracranial progressive disease, and fewer brain metastases) [2] and [3].

Other clinical investigations have studied whether or not the addition of upfront WBRT to SRS treatment is warranted to improve the therapeutic ratio of SRS therapy [4], [5], [6], [7], [8], [9], [10], [11], [12] and [13]. These investigations do demonstrate a reduction in intracranial local and regional failure but have failed to convincingly show a survival benefit associated with the use of WBRT in this setting [14]. Furthermore, the negative neurocognitive impacts associated with the utilization of WBRT have led to a controversy regarding the optimal management of this patient population [15] and [16].

A significant gap in the medical literature exists with regard to models for regional failure risk prediction. Such models would support physician and patient decision-making regarding the potential utility of the WBRT component of SRS treatment of oligometastatic brain disease. Therefore, the purpose of this investigation is to report a clinical nomogram risk calculator and a recursive partitioning analysis (RPA) based risk stratification system for the prediction of 1-year regional brain failure post-SRS treatment without WBRT.

\section{METHODS AND MATERIALS}

\section{SRS database}

The SRS database contains baseline characteristics, treatment details, and clinical outcome follow-up (death, intracranial local and regional failure) data of newly diagnosed BM patients from solid tumors treated with Linac-based SRS for up to three brain metastases without whole brain radiotherapy, which have been previously published after local Institutional Review Board approval [17], [18] and [19]. The median actuarial follow-up duration of the database calculated using the reverse Kaplan-Meier method was 32 months [20]. 


\section{Endpoints}

Four separate endpoints (one primary and three secondary) were utilized in conjunction with this predictive analysis. The primary endpoint for this analysis was cumulative regional failure (RF) at 1-year (binary variable, $n=361$ patients), This was was defined as the presence of at least one regional failure occurring outside of the 95\% PTV isodose line of the treated lesions and occurring within one year of initiation of stereotactic radiosurgery. The 1-year time-point was selected prior to any statistical analysis in order to balance a clinically relevant cut-point (that may compel a clinician to either include/exclude WBRT) with having enough events for appropriately powered statistical modeling. All patients in this investigation had baseline MRI and CT imaging reviewed by study investigators in order to ensure the absence of any untreated lesions/abnormalities at the time of stereotactic treatment planning. Secondary endpoints included overall survival, time to regional failure, and cumulative regional failure.

\section{Statistical methodology}

Univariable logistic and Cox regressions were constructed to identify significant predictors of 1-year RF and time to 1-year RF, respectively. Predictors assessed in this investigation included: age, gender, primary tumor site, primary tumor activity (controlled/resected vs. other), histology, systemic metastases status, World Health Organization performance status, treatment year, gross tumor volumes (GTV, maximum, minimum, and total), use of systemic therapy, and SRS RT schedule. Multivariable logistic and Cox regression analyses were performed, incorporating all factors found to be significant from univariable logistic and Cox regressions respectively (i.e. $p<0.05$ ). Nomograms based on statistically significant factors identified from multivariable logistic modeling of 1-year regional failure probability were constructed.

To internally validate the nomogram, 10-fold cross-validation techniques were used as described by lasonos et al. [21]. The nomogram was also validated in terms of calibration, the extent to which the observed 1-year RF was over- or under-estimated by the nomogram. Receiver operator curves (ROC) and bias corrected concordance indices (cindex) were calculated for the multivariable logistic model, nomogram, and constituent variables.

Recursive partitioning analysis (RPA) was performed, incorporating significant predictors identified from univariable logistic regression (age, number of brain metastases, WHO PS, and maximum GTVsize), modeling RF at 1-year as a dichotomous outcome. KaplanMeier estimates were generated for both RF and OS endpoints, utilizing the log-rank test to explore differences in outcome between the different risk classifications. The RPA generated in this analysis was compared to a pre-existing system described by Rades et al. [22] for the prediction of total intracranial failure to gauge the potential 
improvement in classification. Comparison of the RPA to the Rades system was accomplished by calculation of operating characteristics for 1-year regional failure, area under the receiver operator curve, log-rank testing of Kaplan-Meier curves for regional failure, as well as the calculation of the Net Reclassification Improvement parameter [23].

All general statistical analyses were performed using SAS 9.2 Software (SAS institute, Cary, NC) and the R language environment for statistical computing (open source, www.r-project.org), using two-sided statistical testing at the 0.05 significance level. Recursive partitioning analysis, nomogram and bias-corrected concordance indices (cindex) obtained using R.

\section{RESULTS}

Between December 2002 and July 2011, a total of 361 patients with 508 newly diagnosed BM were treated with linac-based SRS as a single modality. Patient, tumor, and treatment-related descriptive statistics are summarized in Table 1. Dose fractionation schedules were as follows: 21 Gy/1 fraction (171/361 - 47.4\%), 18 Gy/1 fraction (129/361 - 35.7\%), 24 Gy/3 fractions (39/361 - 10.8\%), and 15 Gy/1 fraction (22/361 6.1\%). RF was identified in 115/361patients (31.9\%), 90/361 patients (24.9\%) within 1year of follow-up, and 54/361 (15.0\%) within 6-months of follow-up. Fifty-five (15\%) patients were alive at the last follow-up.

Table 1 Baseline characteristics of all patients ( $n=361$ ) stratified by 1 year regional failure status (yes/no)

\begin{tabular}{|c|c|c|c|c|}
\hline \multirow[t]{2}{*}{ Characteristic } & \multirow{2}{*}{$\begin{array}{l}\text { All patients } \\
(n=361)\end{array}$} & \multicolumn{2}{|c|}{ 1-YEAR Regional Failure } & \multirow[t]{2}{*}{$\mathrm{p}$-Value } \\
\hline & & Yes $(n=90)$ & No $(n=271)$ & \\
\hline Age - mean $\pm S D$, median, (min, max) & $\begin{array}{l}61.28 \pm 11.66 \\
61.33 \\
(16.47,89.10)\end{array}$ & $\begin{array}{l}58.70 \pm 10.56 \\
59.34 \\
(28.87,86.03)\end{array}$ & $\begin{array}{l}62.14 \pm 11.90 \\
62.25 \\
(16.47,89.10)\end{array}$ & 0.015 \\
\hline$\leq 55$ & $113(31.3)$ & $38(42.2)$ & $75(27.7)$ & \\
\hline$>55$ to $\leq 65$ & $112(31.0)$ & $25(27.8)$ & $87(32.1)$ & \\
\hline$>65$ to $\leq 75$ & $92(25.5)$ & $22(24.4)$ & $70(25.8)$ & \\
\hline$>75$ & $44(12.2)$ & $5(5.6)$ & $39(14.4)$ & \\
\hline Male - n (\%) & $168(46.5)$ & $38(42.2)$ & $130(48.0)$ & 0.344 \\
\hline \multicolumn{5}{|l|}{ Primary tumor - n (\%) } \\
\hline Lung & $206(57.1)$ & $48(53.3)$ & $158(58.3)$ & 0.553 \\
\hline Breast & $38(10.5)$ & $11(12.2)$ & $27(10.0)$ & \\
\hline Renal/adrenal? & $27(7.5)$ & $10(11.1)$ & $17(6.3)$ & \\
\hline Colon & $29(8.0)$ & $7(7.8)$ & $22(8.1)$ & \\
\hline Melanoma & $23(6.4)$ & $7(7.8)$ & $16(5.9)$ & \\
\hline Other & $38(10.5)$ & $7(7.8)$ & $31(11.4)$ & \\
\hline
\end{tabular}


Chapter 4

\begin{tabular}{|c|c|c|c|c|}
\hline \multirow[t]{2}{*}{ Characteristic } & \multirow{2}{*}{$\begin{array}{l}\text { All patients } \\
(n=361)\end{array}$} & \multicolumn{2}{|c|}{ 1-YEAR Regional Failure } & \multirow[t]{2}{*}{$p$-Value } \\
\hline & & Yes $(n=90)$ & No $(n=271)$ & \\
\hline \multicolumn{5}{|l|}{ Histology - n (\%) } \\
\hline Adenocarcinoma (non-lung) & $163(45.2)$ & $48(53.3)$ & $115(42.4)$ & \multirow[t]{6}{*}{0.170} \\
\hline NSCLC & $118(32.7)$ & $21(23.3)$ & $97(35.8)$ & \\
\hline Melanoma & $23(6.4)$ & $7(7.8)$ & $16(5.9)$ & \\
\hline Squamous (non-lung) & $21(5.8)$ & $4(4.4)$ & $17(6.3)$ & \\
\hline Renal/adrenal & $12(3.3)$ & $5(5.6)$ & $7(2.6)$ & \\
\hline Other & $24(6.7)$ & $5(5.6)$ & $19(7.0)$ & \\
\hline \multicolumn{5}{|l|}{ Number of brain metastases $-\mathrm{n}(\%)$} \\
\hline 1 & $232(64.3)$ & $44(48.9)$ & $188(69.4)$ & \multirow[t]{2}{*}{$<0.001$} \\
\hline 2 or 3 & $129(35.7)$ & $46(51.1)$ & $83(30.6)$ & \\
\hline Active primary tumor $-\mathrm{n}(\%)$ & $168(46.5)$ & $39(43.3)$ & $129(47.6)$ & 0.482 \\
\hline Systemic metastases - n (\%) & $170(47.1)$ & $40(44.4)$ & $130(48.0)$ & 0.562 \\
\hline \multicolumn{5}{|l|}{ Location - n (\%) } \\
\hline Supra (tentorial?) & $269(74.5)$ & $65(72.2)$ & $204(75.3)$ & \multirow[t]{3}{*}{0.297} \\
\hline Infra & $55(15.2)$ & $12(13.3)$ & $43(15.9)$ & \\
\hline Both & $37(10.3)$ & $13(14.4)$ & $24(8.9)$ & \\
\hline \multicolumn{5}{|l|}{ WHO performance status - n (\%) } \\
\hline 0 & $78(21.6)$ & $30(33.3)$ & $48(17.7)$ & \multirow[t]{4}{*}{0.003} \\
\hline 1 & $215(59.6)$ & $51(56.7)$ & $164(60.5)$ & \\
\hline 2 & $57(15.8)$ & $9(10.0)$ & $48(17.7)$ & \\
\hline 3 & $11(3.1)$ & -- & $11(4.1)$ & \\
\hline \multicolumn{5}{|l|}{ Treatment year - n (\%) } \\
\hline 2002-2004 & 69 (19.1) & $23(25.6)$ & $46(17.0)$ & \multirow[t]{4}{*}{0.130} \\
\hline 2005-2007 & $121(33.5)$ & $32(35.6)$ & $89(32.8)$ & \\
\hline 2008-2009 & $102(28.3)$ & $18(20.0)$ & $84(31.0)$ & \\
\hline 2010-2011 & $69(19.1)$ & $17(18.9)$ & $52(19.2)$ & \\
\hline GTV (Max) - mean \pm SD, median, (min, max) & $\begin{array}{l}7.64 \pm 7.30 \\
5.60 \\
(0.10,44.70)\end{array}$ & $\begin{array}{l}6.14 \pm 4.89 \\
4.80 \\
(0.10,21.10)\end{array}$ & $\begin{array}{l}8.14 \pm 7.90 \\
6.10 \\
(0.10,44.70)\end{array}$ & \multirow[t]{5}{*}{0.005} \\
\hline$\leq 2.50$ & $91(25.4)$ & $23(25.6)$ & $68(25.4)$ & \\
\hline$>2.50$ and $\leq 5.60$ & $90(25.1)$ & $27(30.0)$ & $63(23.5)$ & \\
\hline$>5.60$ and $\leq 10.80$ & $90(25.1)$ & $25(27.8)$ & $65(24.3)$ & \\
\hline$>10.80$ & $87(24.3)$ & $15(16.7)$ & $72(26.9)$ & \\
\hline \multicolumn{5}{|l|}{ Systemic treatment - n (\%) } \\
\hline None & $55(15.2)$ & $9(10.0)$ & $46(17.0)$ & \multirow[t]{3}{*}{0.279} \\
\hline Palliative & $164(45.4)$ & $43(47.8)$ & $121(44.7)$ & \\
\hline Radical & $142(39.3)$ & $38(42.2)$ & $104(38.4)$ & \\
\hline \multicolumn{5}{|l|}{ RT Schedule - n (\%) } \\
\hline 15 Gy in 1 fraction & $22(6.1)$ & $6(6.7)$ & $16(5.9)$ & \multirow[t]{4}{*}{0.509} \\
\hline 18 Gy in 1 fraction & $129(35.7)$ & $32(35.6)$ & $97(35.8)$ & \\
\hline 21 Gy in 1 fraction & $171(47.4)$ & $46(51.1)$ & $125(46.1)$ & \\
\hline 24 Gy in 3 fractions & 39 (10.8) & $6(6.7)$ & $33(12.2)$ & \\
\hline
\end{tabular}




\begin{tabular}{llllll}
\hline Characteristic & $\begin{array}{l}\text { All patients } \\
(\mathrm{n}=361)\end{array}$ & \multicolumn{2}{l}{$\begin{array}{l}\text { 1-YEAR Regional Failure } \\
\text { Yes }(\mathrm{n}=90)\end{array}$} & No $(\mathrm{n}=271)$ & \\
\hline RF RPA-Value & $\mathrm{n}(\%)$ & & & & \\
1 & $68(18.8)$ & $9(10.0)$ & $59(21.8)$ & 0.039 \\
2 & $231(64.0)$ & $62(68.9)$ & $169(62.4)$ & \\
3 & $62(17.2)$ & $19(21.1)$ & $43(15.9)$ & \\
\hline
\end{tabular}

Results from the univariable logistic and Cox regression analyses for RF at 1-year are depicted in Table 2. Significant predictors of 1-year RF from univariable logistic regression were: age $(p=0.016)$, number of brain metastases $(p<0.001)$, WHO performance status ( $p=0.002$ ) and GTV size $(p=0.026)$. Significant predictors of time to 1 -year RF from univariable Cox regression only included number of brain metastases $(p<0.001)$. Similar results to the univariable logistic regression were obtained from descriptive statistical analysis with age $(p=0.015)$, number of brain metastases (chi square $p<$ 0.001), WHO performance status (chi square $p=0.003$ ) and maximum GTV size (chi square $p=0.005$ ) remaining significantly associated with 1-year RF (aspect lesion morphology, chi square $p=0.046$; and Radiation Therapy Oncology Group Recursive Partitioning Analysis Group, chi square $p=0.039$ : Table 1 ).

Results of multivariable logistic and Cox regression analyses incorporating significant predictors from univariable analysis are also summarized in Table 2. Significant predictors of 1-year RF from multivariable logistic regression included: number of brain metastases $(p=0.001)$, WHO performance status $(p=0.017)$ and GTV size $(p=0.045)$. However, age ( $p=0.101$ ) was found to be only of borderline significance. In the context of 1-year RF, number of brain metastases was found to also be a significant predictor of time to RF $(p<0.001)$ on multivariable analysis, however age $(p=0.460)$, GTV size $(p=$ $0.194)$ and WHO performance status ( $p=0.456)$ were not predictive of time to RF. 


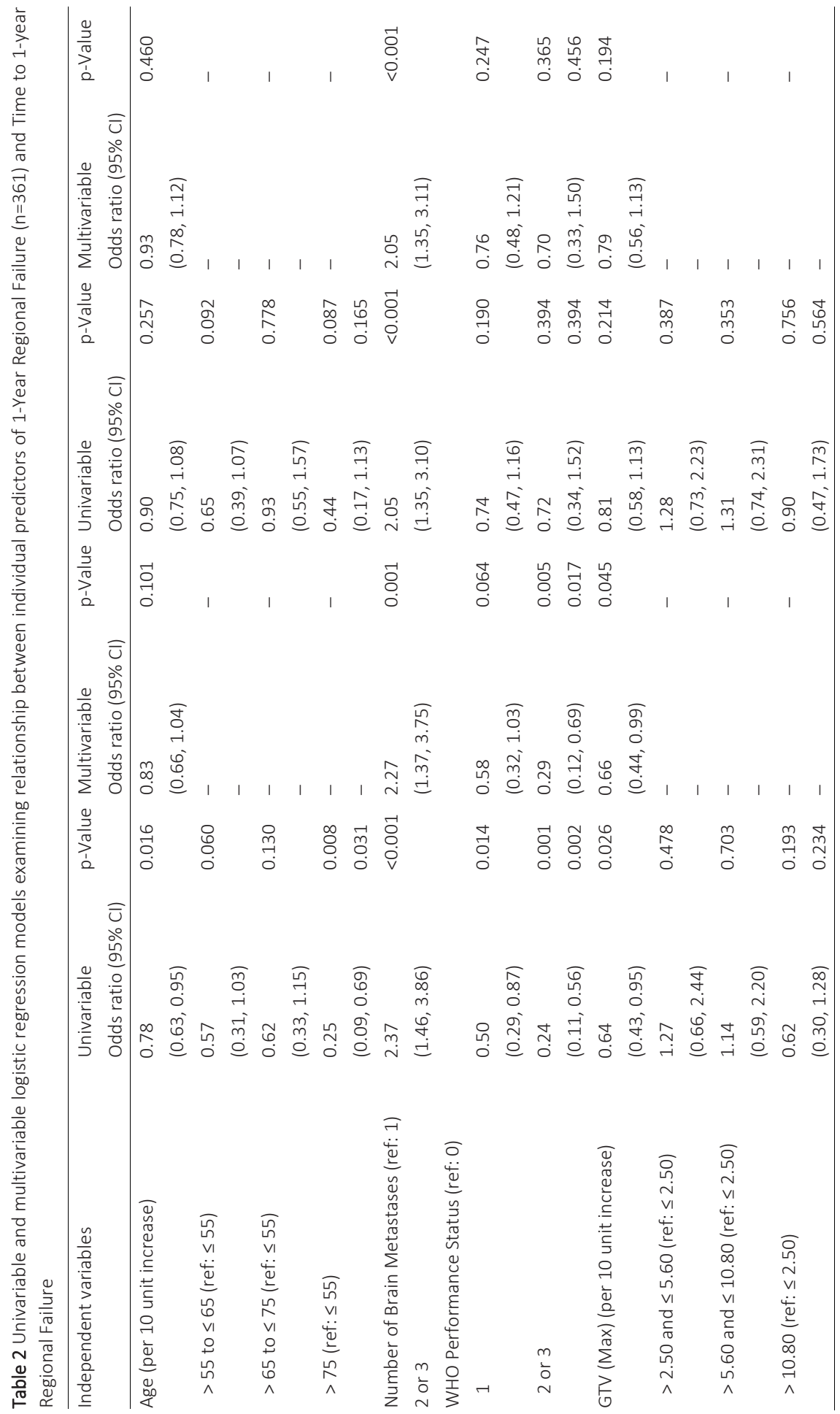


A clinical nomogram for the prediction of 1-year regional failure probability was created using the primary multivariable logistic regression predictive factors of age, lesion number, maximum GTV size, and WHO performance status (Fig. 1, see also online supplemental materials for a nomogram calculator). The calculated concordance index for this nomogram is 0.694 , which is superior to the indices of the constituent variables assessed individually (age $=0.596$, lesion number $=0.604$, GTV size $=0.551$, and WHO performance status $=0.610$, Supplemental Fig. e1). The calibration plot confirmed a high correlation between observed and predicted probability $(r 2=0.9647$, Supplemental Fig. e2). These findings confirm that the four-variable nomogram provides improved predictive ability over any individual variable in isolation.

\section{Points}

Age

Lesion No.

GTV Size (cc)

WHO

Total Points

1-Year RF Probability

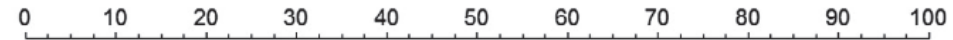

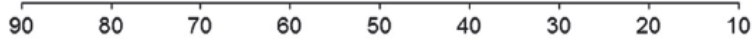

2,3

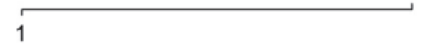

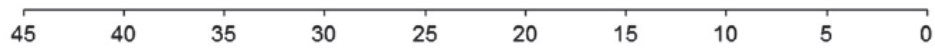

1

2,3

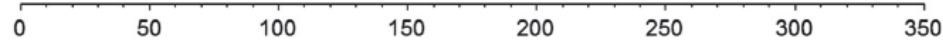

0.0

0.1

$\begin{array}{lllllll}0.2 & 0.3 & 0.4 & 0.5 & 0.6 & 0.7 & 0.8\end{array}$

Figure 1 Clinical nomogram for the prediction of 1-year regional failure probability

As depicted in Fig. 2, the RPA analysis for the dichotomous endpoint, 1-year RF, partitioned the patient population into 3 risk strata defined as follows: low-risk (i.e. $<25 \% 1$ year RF): age > 55Y AND solitary lesion; intermediate-risk (between 25\% and 40\% 1-year $\mathrm{RF}$ ): age $\leq 55 \mathrm{Y}$ AND solitary lesion OR WHO $\geq 1$ AND 2-3 lesions; high-risk (i.e. >40\% 1year RF): WHO = 0 AND 2-3 lesions. The maximum GTV was selected instead of cumulative GTV size for RPA analysis for two reasons: (1) it had favorable statistical properties including superior statistical significance upon univariable logistic regression $(p=0.045$ vs. $p=0.074$ ) and lack of redundancy with the number of brain metastases being already incorporated in the RPA model.

Comparison of the RPA vs. Rades classification demonstrated superior operating characteristics for the prediction of regional failure at 1-year in favor of the RPA including accuracy $(75 \%$ vs. $66 \%$ ), positive predictive value (53\% vs. $26 \%)$, negative predictive value (77\% vs. $75 \%)$ and well as likelihood ratio positive (3.41 vs. 1.04). Area under the receiver operator curve for the RPA and Rades classifications were 0.66 and 0.50 , re- 
spectively. Net reclassification improvement was in favor of the RPA system (NRI = 0.30). The Kaplan-Meier curve assessing regional failure at 1-year per Rades group is depicted in Supplemental Fig. e3. There was no statistical difference between the low and intermediate Rades system groups in terms of regional failure at 1-year (log rank $p$ $=0.139$ ) whereas a statistical difference between RPA groups was found (Fig. 3, log rank $\mathrm{p}<0.001)$.

Hazard/odds ratios related to both primary and secondary endpoints comparing intermediate- and high-risk patients against the reference standard low-risk category demonstrated stepwise increases in risk for 1-year regional failure and time to 1-year regional failure (Supplemental Table e1). Both intermediate- (HR 0.80) and high-risk (HR 0.77) patients had reduced risk of death compared to the low-risk cohort that was not found to reach statistically significant levels (Supplemental Table e1).

Kaplan-Meier curves for all eligible patients using the proposed RF risk stratification system were generated for both time to 1-year RF and OS, as summarized in Fig. 3 and Supplementary Fig. e4, respectively. As depicted in these figures, the classification system demonstrated sufficient divergence in terms of 1-year RF (log-rank $p<0.001)$. For 1-year RF (Fig. 3), each of the risk classifications followed a similar profile during the first phase of follow-up (0-3 months due to lack of early post-treatment imaging, see SRS database methods), after which stage there was substantial divergence in respective risk of RF with 22/164 (13.4\%) patients at low-risk, 51/165 (30.9\%) patients at intermediate-risk, and 17/32 (53.1\%) patients at high-risk developing RF within 1-year of initiation of treatment. For OS (Supplemental Fig. e4), there appeared to be a noticeable decline in survival among low-risk patients (median survival: 6.67 months) compared to intermediate- (9.73 months) and high-risk (8.09 months) patients. This effect was apparent during the entire first two years of follow-up (as shown in Supplemental Fig. e4). Actuarial estimates (abstracted from the Kaplan-Meier Curves) for time to regional failure and overall survival at 3, 6, 9, and 12 months are summarized in Supplemental Table e2.

\section{DISCUSSION}

Assessment and prediction of clinical outcome after radiotherapy for brain metastases are areas of active research in the medical literature [24], [25] and [26]. Four factors were found to predict for the presence or absence of regional failure within a year of SRS therapy as a single modality; which included patient age, maximum gross tumor volume, WHO PS, and the number of brain metastases. Only number of brain metastases was found to predict for the timing of such a failure within the 1-year time frame post-SRS. The clinical nomogram that was created in this investigation incorporates each of the four factors as listed previously to calculate a 1-year RF risk probability (Fig. 
1). Interestingly, smaller GTV size confers a higher RF risk in the multivariable model and its associated clinical nomogram. It is hypothesized that patients with one or more smaller lesions are likely to have better local control of disease that may provide an increased risk of RF to manifest itself. Alternatively, one or more small lesions may predict for subclinical microscopic disease not detected by baseline MRI imaging; whereas patients with larger lesions without additional lesions (detected by baseline MRI) may be at lower RF risk due to the true absence of such disease. The lack of impact of extracranial metastases and primary tumor status on 1-year RF suggests that the impact of reseeding of the brain from extracranial sites may not be a predominant issue in RF risk.

A RPA for the risk stratification of 1-year RF was created using the four statistically significant multivariable factors as initial input. The RPA had superior operating characteristic, Kaplan-Meier, and Net Reclassification Improvement properties when compared to the Rades system predicting for total intracranial control. This finding is not surprising as the RPA was specifically designed to predict for regional failure; whereas, the Rades classification was designed to assess total intracranial failure (both lesional and regional). Nothwithstanding this issue, this comparison does illustrate the utility of the RPA over another pre-existing classification system.

Interestingly, although the RPA was designed to assess the 1-year timepoint, close inspection of the Kaplan-Meier curves in Fig. 3 demonstrate that this RPA system does start to discriminate patients into separate risk groups as early as two-month post-SRS. Ultimately, a RPA using three factors (age with 55-year cutoff, number of metastases with 1 vs. 2/3 metastases cutoff, and WHO PS 0 vs. $\geq 1$, Fig. 2) was created to define three distinct risk groupings as follows:

- Low-risk (<25\% 1-year RF): \{Age > 55Y AND solitary lesion\}

- Intermediate-risk (25-40\% 1-year RF): $\{$ Age $\leq 55$ Y AND solitary lesion $\}$ OR $\{$ WHO $\geq 1$ AND 2-3 lesions\}

- High-risk (>40\% 1-year RF): $\{$ WHO = 0 AND 2-3 lesions $\}$

A risk-stratification RPA approach may be less versatile than a clinical nomogram given the lack of a precise estimate of RF risk at 1-year; however, the definition of specific groups (with defined outcomes) based on clinically available information at the time of patient evaluation for SRS can still be highly attractive to clinicians and for the stratification of clinical trials. Clinical management and outcome prediction using risk stratification systems are common in the medical literature and in clinical practice with examples in brain metastases, prostate cancer, among other cancers. Alternatively, this clinical nomogram can provide an estimate of RF at 1-year that can specifically advise physicians and patients on the advisability of integrating upfront WBRT as part of SRS therapy. Whereas the RPA risk-stratification system "locks" clinicians to a priori defined 1year RF cutoffs of $25 \%$ and $40 \%$, clinical nomograms can provide continuous risk estimates for individualized risk assessment and decision-making by clinicians and patients. 
Specifically, the number of patients needed to observe (NNO, for patients treated with SRS without WBRT) to detect one RF at 1-year can be calculated by taking the inverse of the clinical nomogram risk estimate. For example, if the clinical nomogram predicts a risk of $20 \%$ vs. $50 \%$ risk of RF at 1-year, the NNO would be calculated at 5 patients and 2 patients, respectively. This information can be communicated to patients in order to make individualized decisions regarding the advisability of WBRT given the known reduction of RF risk (estimated to be as high as a 65\% relative risk reduction) associated with the integration of WBRT with SRS therapy [10] and [14].

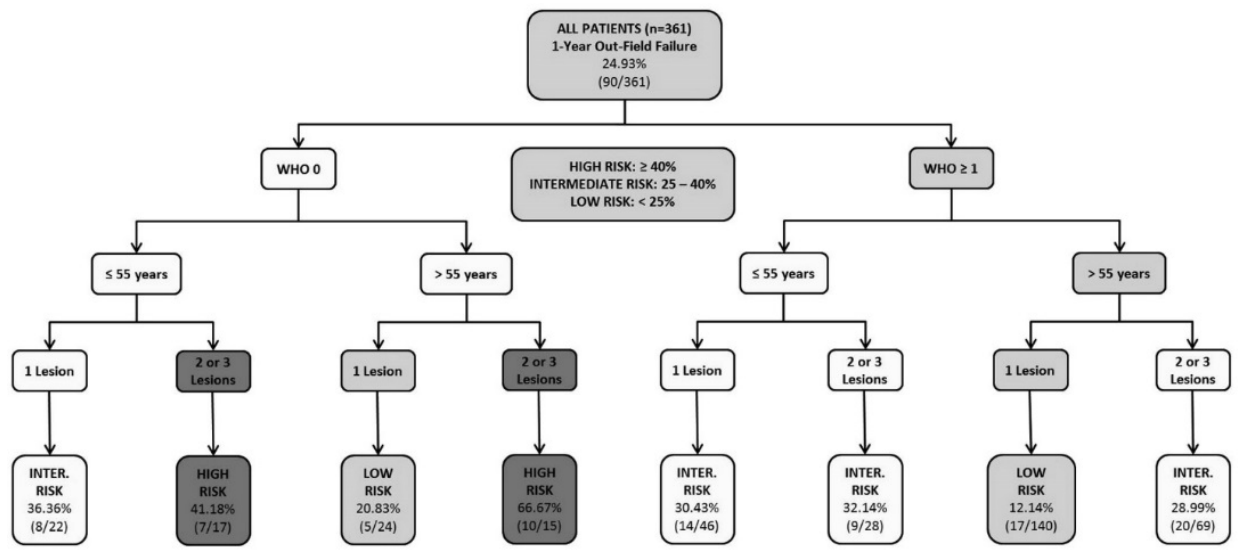

Figure 2 Recursive partitioning analysis grouping into three risk categories for the prediction of 1-year regional failure risk

The limitation of this work is that it is based on retrospective single institutional data and validation of its findings in an external dataset will need to be performed. Histology was not found to be statistically associated with regional risk in this analysis. Further analysis of the relationship between specific subtypes of cancer (HER-subtypes of breast cancer, adenocarcinoma of lung) as well as other factors described in the literature (e.g. extracranial control in NSCLC) to regional failure risk may further shed light on this issue. Other limitations include the lack of robust neurocognitive outcome data and WBRT/SRS data in the database to extend our analyses. Future research should continue to define the indications for the integration of WBRT with SRS therapy in order to balance the positive neurocognitive effects of regional control with the negative neurocognitive effects inherent with regional treatment of the cranium. Other modeling strategies, such as artificial neural networks, may provide additional insight in optimizing treatment decision-making for this challenging patient population. Further investigation to define a very early failure endpoint in terms of timing and extent of relapse would be of interest. 
A Clinical Nomogram and Recursive Partitioning Analysis to Determine the Risk

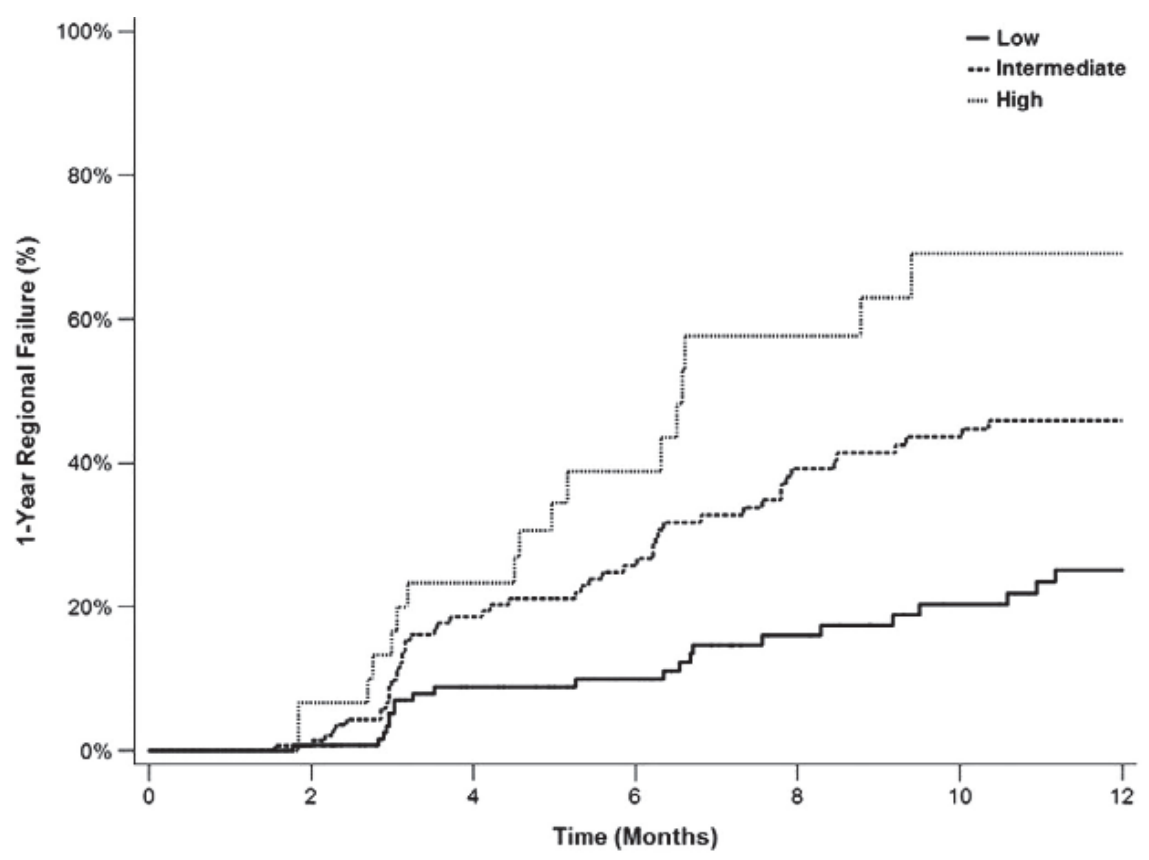

Number at risk:

$\begin{array}{lccccccc}\text { Low: } & 164 & 127 & 93 & 82 & 62 & 53 & 44 \\ \text { Int: } & 165 & 140 & 99 & 77 & 56 & 50 & 43 \\ \text { High: } & 32 & 28 & 22 & 13 & 9 & 4 & 4\end{array}$

Log-rank: $p<0.001$

Figure 3 Kaplan-Meier curve for 1-year regional failure by RPA-risk group 


\section{REFERENCES}

[1] Andrews DW, Scott CB, Sperduto PW, et al. Whole brain radiation therapy with or without stereotactic radiosurgery boost for patients with one to three brain metastases: phase III results of the RTOG 9508 randomised trial. Lancet 2004;363:1665-72.

[2] Rades D, Bohlen G, Pluemer A, et al. Stereotactic radiosurgery alone versus resection plus whole-brain radiotherapyfor 1 or 2 brain metastases in recursive partitioning analysis class 1 and 2 patients. Cancer 2007; 109:2515-21.

[3] Kocher M, Maarouf M, Bendel M, et al. Linac radiosurgeryversus whole brain radiotherapy for brain metastases. A survival comparison basedon the RTOG recursive partitioning analysis. Strahlenther Onkol 2004;180:263-7.

[4] Aoyama H, Shirato H, Tago M, et al. Stereotactic radiosurgery plus whole-brain radiation therapy vs stereotactic radiosurgery alone for treatment of brain metastases: a randomized controlled trial. JAMA 2006;295:2483-91.

[5] Aoyama H, Tago M, Kato N, et al. Neurocognitive function of patients with brain metastasis who received either whole brain radiotherapy plus stereotactic radiosurgery or radiosurgery alone. Int J Radiat Oncol Biol Phys 2007;68:1388-95.

[6] Chang EL, Wefel JS, Hess KR, et al. Neurocognition in patients with brain metastases treated with radiosurgery or radiosurgery plus whole-brain irradiation: a randomised controlled trial. Lancet Oncol 2009;10:1037-44.

[7] Chidel MA, Suh JH, Reddy CA, et al. Application of recursive partitioning analysis and evaluation of the use of whole brain radiation among patients treated with stereotactic radiosurgery for newly diagnosed brain metastases. Int J Radiat Oncol Biol Phys 2000;47:993-9.

[8] Kocher M, Soffietti R, Abacioglu U, et al. Adjuvant whole-brain radiotherapy versus observation after radiosurgery or surgical resection of one to three cerebral metastases: results of the EORTC 2295226001 study. J Clin Oncol 2011;29:134-41.

[9] Pirzkall A, Debus J, Lohr F, et al. Radiosurgery alone or in combination with whole-brain radiotherapy for brain metastases. J Clin Oncol 1998;16:3563-9.

[10] Rades D, Kueter JD, Hornung D, et al. Comparison of stereotactic radiosurgery (SRS) alone and whole brain radiotherapy (WBRT) plus a stereotactic boost (WBRT+SRS) for one to three brain metastases. Strahlenther Onkol 2008;184:655-62.

[11] Shehata MK, Young B, Reid B, et al. Stereotatic radiosurgery of 468 brain metastases < or $=2 \mathrm{~cm}$ : implications for SRS dose and whole brain radiation therapy. Int J Radiat Oncol Biol Phys 2004;59:87-93.

[12] Sneed PK, Lamborn KR, Forstner JM, et al. Radiosurgery for brain metastases: is whole brain radiotherapy necessary? Int J Radiat Oncol Biol Phys 1999;43:549-58.

[13] Varlotto JM, Flickinger JC, Niranjan A, et al. The impact of whole-brain radiation therapy on the longterm control and morbidity of patients surviving more than one year after gamma knife radiosurgery for brain metastases. Int J Radiat Oncol Biol Phys 2005;62:1125-32.

[14] Rades D, Schild SE. Do patients with a limited number of brain metastases need whole-brain radiotherapy in addition to radiosurgery? Strahlenther Onkol 2012;188:702-6.

[15] Peacock KH, Lesser GJ. Current therapeutic approaches in patients with brain metastases. Curr Treat Options Oncol 2006;7:479-89.

[16] Soffietti R, Kocher M, Abacioglu UM, et al. A European Organisation for Research and Treatment of Cancer phase III trial of adjuvant whole-brain radiotherapy versus observation in patients with one to three brain metastases from solid tumors after surgical resection or radiosurgery: quality-of-life results. J Clin Oncol 2013;31:65-72.

[17] Rodrigues G, Zindler J, Warner A, et al. Recursive partitioning analysis for the prediction of stereotactic radiosurgery brain metastases lesion control. Oncologist 2013;18:330-5.

[18] Zindler JD, Rodrigues G, Haasbeek CJ, et al. The clinical utility of prognostic scoring systems in patients with brain metastases treated with radiosurgery. Radiother Oncol 2013;106:370-4. 
[19] Verbakel WF, Lagerwaard FJ, Verduin AJ, Heukelom S, Slotman BJ, Cuijpers JP. The accuracy of frameless stereotactic intracranial radiosurgery. Radiother Oncol 2010;97:390-4.

[20] Schemper M, Smith TL. A note on quantifying follow-up in studies of failure time. Control Clin Trials 1996;17:343-6. G. Rodrigues et al. / Radiotherapy and Oncology 111 (2014) 52-58 57

[21] lasonos A, Schrag D, Raj GV, Panageas KS. How to build and interpret a nomogram for cancer prognosis. J Clin Oncol 2008;26:1364-70.

[22] Rades D, Dziggel L, Haatanen T, et al. Scoring systems to estimate intracerebral control and survival rates of patients irradiated for brain metastases. Int J Radiat Oncol Biol Phys 2011;80:1122-7.

[23] Pencina MJ, D'Agostino Sr RB, D'Agostino Jr RB, Vasan RS. Evaluating the added predictive ability of a new marker: from area under the ROC curve to reclassification and beyond. Stat Med 2008;27:157-72.

[24] Scoccianti S, Ricardi U. Treatment of brain metastases: review of phase III randomized controlled trials. Radiother Oncol 2012;102:168-79.

[25] Rades D, Dziggel L, Nagy V, et al. A new survival score for patients with brain metastases who received whole-brain radiotherapy (WBRT) alone. Radiother Oncol 2013;108:123-7.

[26] Harth S, Abo-Madyan Y, Zheng L, et al. Estimation of intracranial failure risk following hippocampalsparing whole brain radiotherapy. Radiother Oncol 2013. pii: S0167-8140(13)00467-2. 



\section{Chapter}

\section{Patterns of distant brain recurrences after radiosurgery alone for newly diagnosed brain metastases: Implications for salvage therapy}




\section{ABSTRACT}

Introduction Single modality radiosurgery (RS) is an established treatment option for patients with brain metastases (BM) with the aim of achieving optimal local control while avoiding toxicity from whole brain radiotherapy (WBRT). Published studies generally lack detailed data on distant brain recurrence (DBR) rates and characteristics. This study describes the patterns of DBR and consequences for salvage treatment in a group of patients treated with RS alone for 1-3 BM.

Materials and methods Between 2002 and 2012, 443 patients were treated with RS alone in doses ranging 15-24 Gy in 1-3 fractions. Patient selection for RS was performed using triple dose gadolinium-enhanced MRI scans, obtained with slice distance of $2 \mathrm{~mm}$ (until 2008), $1.5 \mathrm{~mm}$ (2008-2012), and of $1 \mathrm{~mm}$ (from 2012). During follow-up, a DBR was observed in 147 patients, but in 20 of these patients (14\%) these "new lesions" could retrospectively be seen on the planning MRI scan. These missed metastases had a median size of $2 \mathrm{~mm}$, and in order to study real DBR patterns, these patients were excluded from analysis.

Results Actuarial DBR rates at 6, 12 and 24 months in the remaining 423 patients were $21 \%, 41 \%$ and $54 \%$, respectively, with a median time to DBR of 5.6 months. In $42 \%$ of $\mathrm{DBR}$, a single new lesion was seen, in $70 \%$ there were $\leq 3$ new lesions. Median diameter of the DBR was $6 \mathrm{~mm}$; $97 \%$ of lesions were $\leq 30 \mathrm{~mm}$. Salvage therapy was delivered in $82 \%$ of DBR patients, consisting of WBRT (46\%), repeated RS (27\%), or systemic treatment (9\%). A RPA classification system (DBR-RPA), based on WHO performance status and interval between initial RS and diagnosis of DBR, was developed to estimate life expectancy after the development of DBR, which can be used to guide salvage therapy.

Conclusions In this study of patients treated with RS alone, only $25 \%$ of treated patients needed salvage treatment for DBR, and ultimately only $18 \%$ of all patients underwent WBRT at any time during follow-up. A three-monthly MRI follow-up scheme identifies DBR at an early stage with respect to size and number of lesions, and most patients were asymptomatic at radiological diagnosis. 


\section{INTRODUCTION}

Radiosurgery (RS) is an established treatment modality for patients with a limited number of brain metastases (BM) in a good physical condition [1]. After single modality RS for oligometastatic BM, there is a substantial risk of developing distant brain recurrences (DBRs) of $52 \%$ up to $76 \%$, which can cause neurologic morbidity or mortality [2] and [3]. High resolution imaging is useful to detect DBR at an early stage [4]. The incidence of DBR can be reduced by combining RS and whole brain radiotherapy (WBRT), but the randomized EORTC 22952-26001 study has confirmed previous reports showing that the addition of WBRT does not prolong overall survival in patients with up to 3 BM treated with RS or surgery [3] and [5]. Characteristics on DBR and salvage treatments have not been reported in detail.

The frequency of follow-up after RS for BM remains a matter of debate. The ASTRO guidelines for follow-up of these patients after RS do not specify the frequency and imaging protocol [6]. Within the EORTC 22952-26001 study, patients were imaged at every three month follow-up with MRI. At our center, MRI scans are similarly performed at 3 monthly intervals during the first 2 years, and every half year thereafter, as long as this is indicated by the clinical condition with consequences for salvage therapy.

This study was performed to assess the characteristics of DBR with respect to number, size and timing after RS alone, detected with such systematic follow-up, and to describe the frequency of salvage options used in a clinical setting.

\section{MATERIALS AND METHODS}

\section{Radiosurgery}

In our institutional database, baseline characteristics, treatment details and follow-up data of newly diagnosed BM patients treated with Linac-based RS have been collected retrospectively [1]. According to our protocol, patients with 1-3 BM are eligible for RS as a single modality. Patient selection for RS alone was performed using triple dose gadolinium-enhanced MRI scans (1.5-2 Tesla), prior to 2008 obtained with $2 \mathrm{~mm}$ slice distance, from 2008 to 2011 with $1.5 \mathrm{~mm}$ slice distance, and from early 2012 with $1 \mathrm{~mm}$ slice distance. RS has been delivered using 5 dynamic conformal arcs on a Novalis (2002-2008) or Novalis TX (2008 onwards) linear accelerator (BrainLAB AG, Feldkirchen, Germany). Patient fixation was performed using the relocatable Gill-Thomas-Cosman frame (2002-2008), and as of 2008 using the BrainLAB's frameless mask system (Brain$L A B$, Feldkirchen, Germany). The RS target volumes consisted of the gross target volume contoured on the planning MRI with a $1 \mathrm{~mm}$ margin to correct for potential setupinaccuracies. RS was prescribed using a 'risk-adapted' fractionation, with lesions $\leq 7.5$ 
$\mathrm{cm}^{3}$ receiving $21 \mathrm{~Gy}$ prescribed at the encompassing $80 \%$ isodose line. For lesions measuring $7.5-25 \mathrm{~cm}^{3}$ or $\mathrm{BM}$ that were adjacent to the brainstem, the prescription dose was $18 \mathrm{~Gy}$ at the $80 \%$ isodose. For the largest lesions with volumes exceeding 25 $\mathrm{cm}^{3}$, a single fraction of $15 \mathrm{~Gy}$ or 3 fractions of $8 \mathrm{~Gy}$, both prescribed at the $80 \%$ isodoses were used. Follow-up included clinical visits and MRI scans at three-monthly intervals during the first two years of follow-up, and every half year thereafter as long as clinically indicated. Additional imaging was performed as indicated by neurological symptoms.

Follow up MRIs were co-registered with pretreatment planning MRIs to assess whether early DBRs had already been visible prior to RS in retrospect. The maximal diameter of the largest DBR at first diagnosis was determined on T1 gadolinium-enhanced axial MRI slices. The medical chart of the patient was consulted to determine if a patient was symptomatic or asymptomatic at the time of diagnosis of DBR. Moreover, considerations regarding the application and outcome of salvage treatments were noted.

\section{Statistics}

Survival was calculated from the date of RS, survival after DBR was calculated from the date of the MRI on which the DBR was diagnosed. Follow-up was calculated with the reverse Kaplan-Meier method [7]. Univariable Log-rank test and multivariable Cox regression analysis were used to determine risk factors for death after the diagnosis of DBR. Based on 2 significant risk factors for survival after DBR, a recursive partitioning analysis was done to divide the population into three groups: favorable, intermediate, and poor survival. All statistical analyses were performed using SPSS (version 19.0, IBM), using two-sided statistical testing at the $5 \%$ significance level.

\section{RESULTS}

Between 2002 and 2012, a total of 443 patients with 595 newly diagnosed BM were treated with RS as a single modality. A total of 147 patients with DBR were identified. However, in 20 patients these "DBR" could be seen in retrospect on the stereotactic planning MRI scan. These missed metastases had a median size of $2 \mathrm{~mm}$, and in order to study real DBR patterns, these patients were excluded from analysis. The remaining 423 patients had a median age of 62 years (range 16 up to 89 years) with the majority of patients (59\%) having primary lung cancer. In total 271 (64\%) of patients underwent RS for a single BM, 132 (31\%) for two lesions and only 20 (5\%) underwent RS for 3 lesions [1].

In the 423 analyzed patients, the median overall survival (OS) was 7.9 months, with OS rates of $58 \%$ and $15 \%$ at 6 and 24 months, respectively. The median follow-up duration was 29.7 months. A DBR was diagnosed in 127 (30\%) of 423 treated patients. The median time from RS to development of DBR was 5.6 months (range 1.5-57.3 months), with 
actuarial DBR free survival rates of $79 \%$ and $46 \%$ at 6 and 24 months, respectively (Fig. 1). In a previous publication of this cohort of patients, a clinical nomogram was described for the prediction of

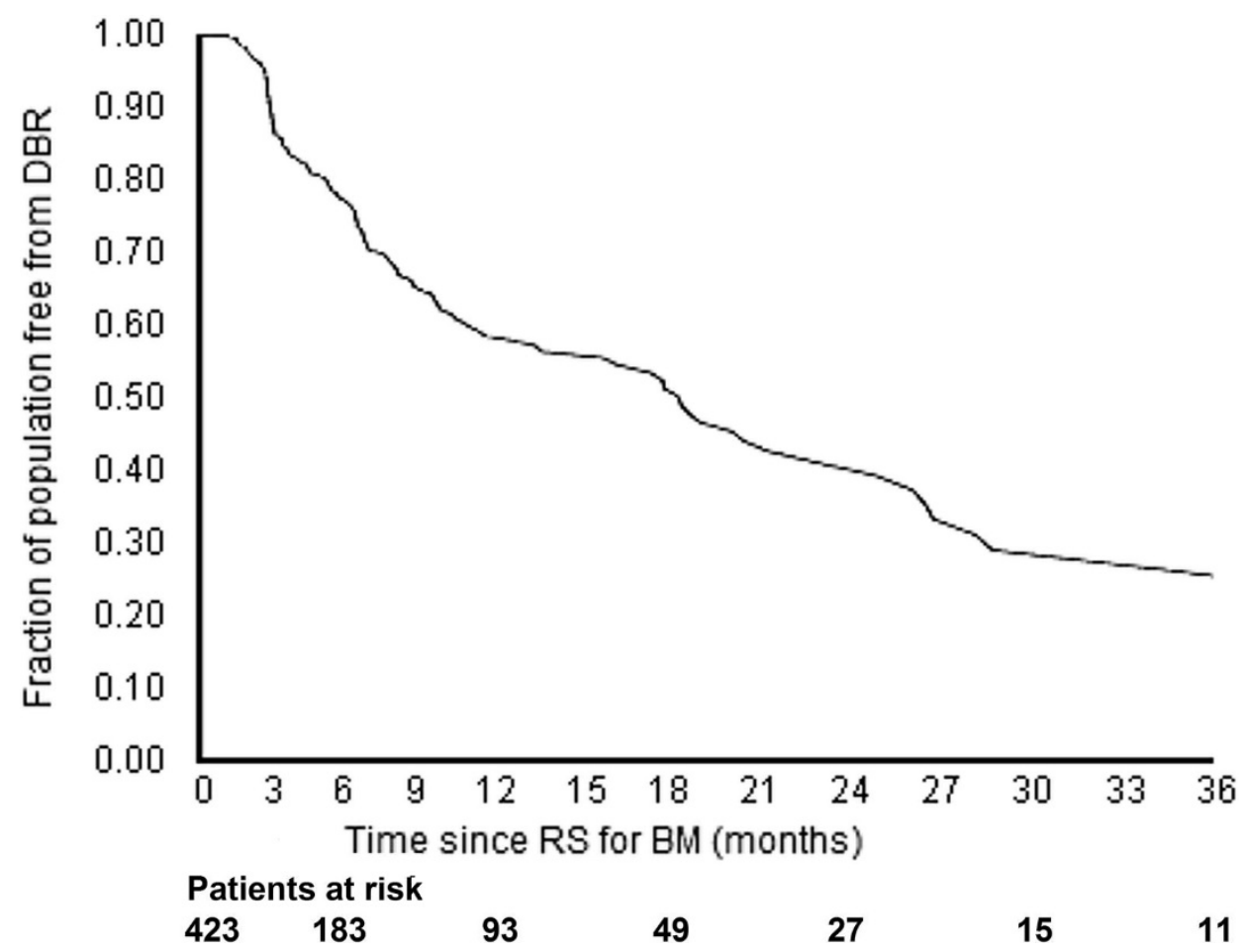

Figure 1 Kaplan-Meyer analysis for risk of DBR after RS for BM ( $N=423)$. Legend: DBR = distant brain recurrence, $\mathrm{RS}=$ radiosurgery, $\mathrm{BM}=$ brain metastases.

At the time of DBR, the majority of patients (70\%) had 1-3 new BM, with $42 \%$ presenting with only a single lesion (Fig. 2A). The median size of the largest new BM was $6 \mathrm{~mm}$, with $77 \%$ of the patients having a new $B M \leq 1 \mathrm{~cm}, 92 \% \leq 2 \mathrm{~cm}$, and $97 \% \leq 3 \mathrm{~cm}$ (Fig. 2B). Most DBRs were asymptomatic (65\%) at the time of diagnosis; in $10 \%$ no record on the clinical status at the time of DBR could be found. 
0.50
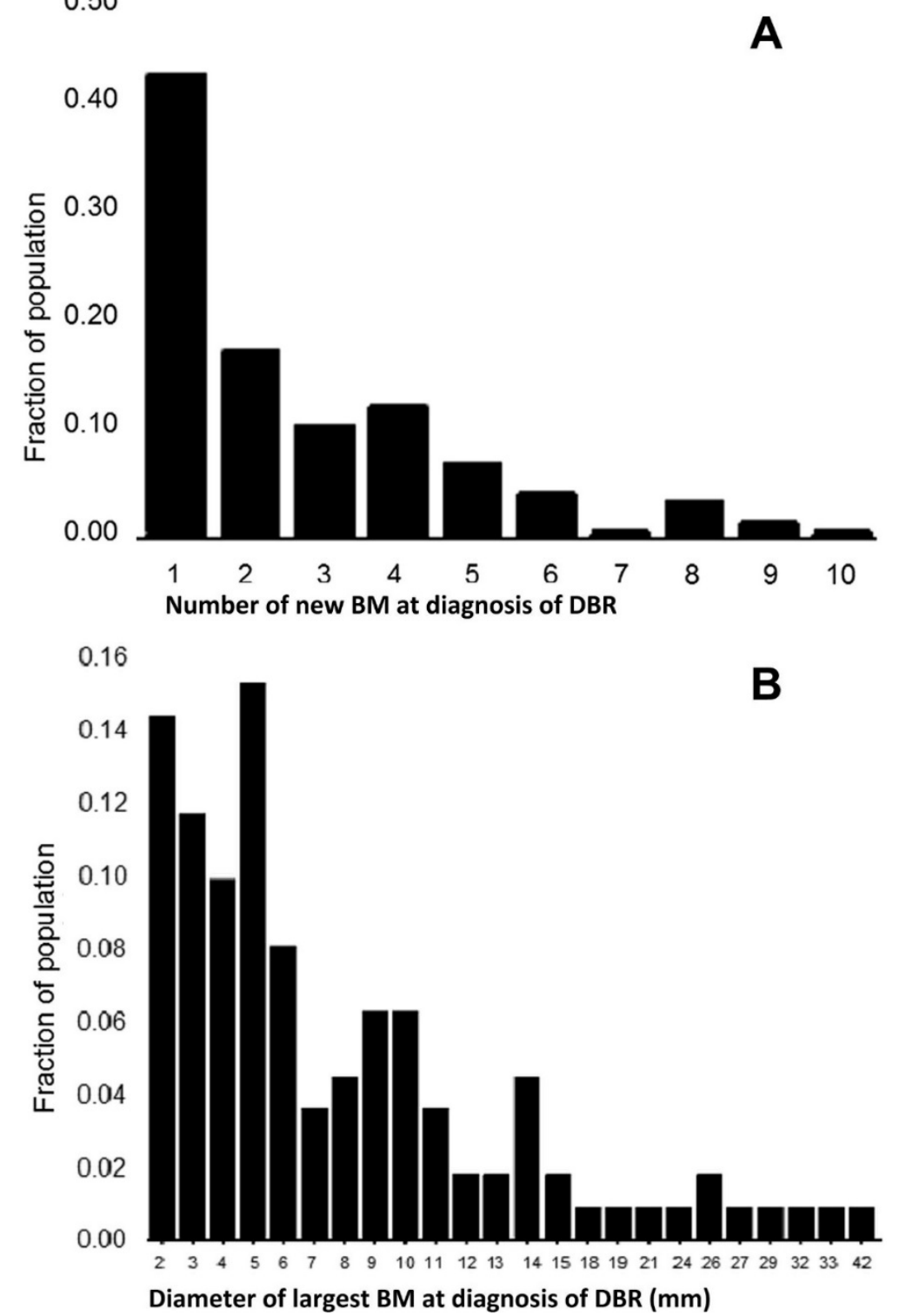

Figure 2 Number $(A)$ of new BM and diameter $(B)$ of the largest BM ( $N=127)$ at diagnosis of DBR. Legend: BM $=$ brain metastases, $\mathrm{DBR}=$ distant brain recurrence.

The median OS after diagnosis of a DBR was 6.1 months with OS rates of $25 \%$ and $7 \%$ at 12 and 24 months, respectively. In both univariate and multivariate analyses, the four characteristics that were predictive for survival at the time of diagnosis of DBR were WHO performance status, early occurrence of DBR (e.g. within 6 months after RS), di- 
ameter of the largest new brain metastasis, and the presence of extracranial metastases (Table 1).

Based on the above results, a recursive partitioning analysis (DBR-RPA) was developed for the prediction of OS after diagnosis of a DBR (Fig. 3). Patients with WHO performance status $\geq 2$ were found to have the poorest prognosis with an OS of 3.4 months, i.e. DBR-RPA class III. At the next level, patients with WHO performance score $0-1$ were divided with respect to the interval between the initial RS and the diagnosis of DBR. The most favorable subgroup (DBR-RPA class I) was patients with a long interval (i.e. $\geq 6$ months) who had a median OS of 10.3 months. The intermediate DBR-RPA class II group with short interval between RS and DBR had a median OS of 5.4 months. The OS of the derived DBR-RPA groups was significantly different; $(p<0.001$; Fig. 4). There appeared to be a balanced distribution of the DBR population over the prognostic groups, with 45 (35\%) patients in DBR-RPA class I, 40 (32\%) patients in DBR-RPA class II, and 42 (33\%) in DBR-RPA class III.

Salvage therapy was eventually delivered in 104 patients (82\% of DBR patients; $25 \%$ of all RS patients), consisting of salvage WBRT in 58 patients ( $46 \%$ of DBR patients; $14 \%$ of all patients), repeat RS in 34 patients (27\% of DBR patients; $8 \%$ of all patients) or systemic treatment in 12 patients ( $9 \%$ of DBR patients; $3 \%$ of all patients). Salvage therapy for DBR was more frequently delivered to symptomatic patients $(89 \%)$ than for asymptomatic patients (75\%). Salvage treatment was delivered in $60 \%(25 / 42)$ of DBR-RPA class III patients, in $87 \%$ (35/40) of RPA class II patients, and in 98\% (44/45) of DBR-RPA class I patients. For all 127 patients with a DBR, the median OS after repeat-RS was 9.9 months, after WBRT salvage 6.2 months, and without salvage treatment 3.5 months. 


\section{Chapter 5}

Table 1 Prognostic factors for survival after diagnosis of DBR $(\mathrm{N}=127)$. Legend: $\mathrm{DBR}=$ distant brain recurrence, OS=overall survival, NS=non-significant, RS=radiosurgery

\begin{tabular}{|c|c|c|c|c|}
\hline Characteristics of DBR & Number of patients & $\begin{array}{l}\text { Median OS } \\
\text { (in months) }\end{array}$ & $\begin{array}{l}\mathrm{p} \text {-Value multivariate } \\
\text { analysis }\end{array}$ & $\begin{array}{l}\text { Hazaro } \\
\text { ratio }\end{array}$ \\
\hline Number of DBR & & & & NS \\
\hline $1-2$ & $69(54 \%)$ & & & \\
\hline 3 or more & $58(46 \%)$ & & & \\
\hline Diameter of the largest DBR & & & & NS \\
\hline$<6 \mathrm{~mm}$ & $57(45 \%)$ & & & \\
\hline$\geq 6 \mathrm{~mm}$ & $70(55 \%)$ & & & \\
\hline Time from RS to DBR & & & $<0.001$ & 2.4 \\
\hline$<6$ months & 65 (51\%) & 4.0 & & \\
\hline$\geq 6$ months & $62(49 \%)$ & 9.5 & & \\
\hline Asymptomatic DBR & $82(65 \%)$ & 8.9 & $<0.001$ & 1.9 \\
\hline Symptomatic DBR & $32(25 \%)$ & 4.9 & & \\
\hline Unknown symptomatology & $13(10 \%)$ & 3.0 & & \\
\hline DBR only & $107(84 \%)$ & & & NS \\
\hline DBR and local recurrence & $20(16 \%)$ & & & \\
\hline Age & & & & NS \\
\hline$<65$ years & $88(69 \%)$ & & & \\
\hline$\geq 65$ years & 39 (31\%) & & & \\
\hline Gender & & & & NS \\
\hline Male & $54(43 \%)$ & & & \\
\hline Female & $73(58 \%)$ & & & \\
\hline $\begin{array}{l}\text { WHO performance status at the } \\
\text { diagnosis DBR }\end{array}$ & & & 0.032 & 1.7 \\
\hline $0-1$ & $85(67 \%)$ & 8.9 & & \\
\hline $2-4$ & $42(33 \%)$ & 3.4 & & \\
\hline Primary tumor & & & & NS \\
\hline Lung & $70(55 \%)$ & & & \\
\hline Breast & $18(14 \%)$ & & & \\
\hline Renal & $14(11 \%)$ & & & \\
\hline Melanoma & $9(7 \%)$ & & & \\
\hline Colon & $8(6 \%)$ & & & \\
\hline Other primary tumors & $8(6 \%)$ & & & \\
\hline Extracranial metastases & & & $<0.001$ & 2.5 \\
\hline Yes & 78 (61\%) & 5.8 & & \\
\hline No & 49 (39\%) & 9.9 & & \\
\hline Primary tumor active & & & & NS \\
\hline Yes & $71(56 \%)$ & & & \\
\hline No & $56(44 \%)$ & & & \\
\hline
\end{tabular}




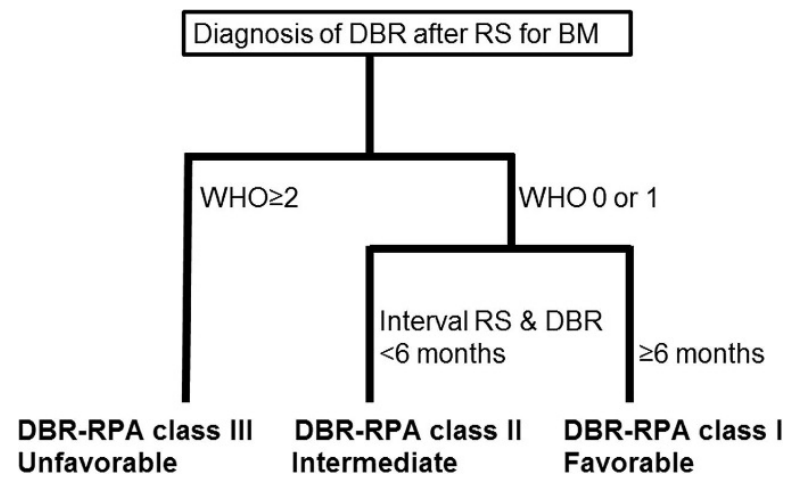

Figure 3 Prognostic classification for survival after diagnosis of DBR (DBR-RPA). Legend: DBR = distant brain recurrence, $\mathrm{RS}=$ radiosurgery, $\mathrm{BM}=$ brain metastases, $\mathrm{WHO}=$ World Health Organization performance status, RPA = recursive partitioning analysis.

\section{DISCUSSION}

As a result of several randomized studies, RS alone is the preferred treatment in patients with a limited number of BM in good performance status. Additional WBRT and its associated toxicity can be avoided without compromising survival [3], [9], [10], [11] and [12]. RS alone provides high rates of local control with low toxicity, is a non-invasive outpatient treatment, however carries a substantial risk of the development of DBR. One of the first, although obvious, observations is the importance of high-resolution imaging for the selection of RS alone patients, which has been highlighted in the literature [4]. In $5 \%$ of our patients ( $14 \%$ of patients initially diagnosed with DBR), 'new lesions' were in retrospect already discernable on the planning MRI with a median size of $2 \mathrm{~mm}$. This incidence of missed BM has decreased dramatically at our center in recent years with growing awareness and the introduction of thin-slice high resolution pre-RS imaging from 7\% (16/230 patients) prior to 2009 to 2\% (4/213 patients) after 2009.

Risk factors for the occurrence of DBR after RS as a single modality for BM have previously been reported for this patient series and a clinical nomogram has been published recently for assessing the risk of DBR from baseline factors, including the number of brain metastases, WHO performance status, and the volume of the largest treated BM [8]. The actuarial incidence of DBR in this study of $21 \%$ and $54 \%$ at 6 and 24 months, respectively, correlates well with that observed in the RS alone arm of the EORTC 22952-26001 trial [3]. This incidence has to be viewed with caution as in both studies only small proportions (5\% and $9 \%$ for this study and the EORTC study, respectively) underwent RS for three BM. In the JROSG 99-1 study reported by Aoyama et al. [2], a higher cumulative incidence of $76 \%$ of DBR at 12 months was reported, however, in this study only $49 \%$ of patients received RS for a single lesion and up to 4 BM were considered eligible. 
Routine follow-up after RS alone for BM at our center consists of 3 monthly clinic visits combined with MRI for the first 2 years after RS, and every half year thereafter. The most recent ASTRO guidelines also recommend regular follow-up after RS procedures, but the frequency and imaging protocol were not specifically addressed [6]. In view of the median time to the development of DBR of 5.6 months, a three-monthly follow-up scheme seems to be a reasonable approach. Not only does such an approach capture DBRs at an asymptomatic stage in $65 \%$ of patients, but also with a size $\leq 3 \mathrm{~cm}$ in $97 \%$ of patients, allowing for repeat-RS when indicated by the number of DBR. The observation that OS after RS alone is similar to that of RS combined with WBRT, despite a significant higher risk of intracranial relapses, has been attributed to effective salvage therapy for DBR. Several salvage treatment options are available for DBR such as repeat-RS, WBRT, or systemic therapy. The median survival of 6.1 months (and even longer than 1 year for selected patients with repeat-RS) underscores the importance of standardized followup allowing for the detection of DBR at an early stage.

Just as in the primary setting of RS [1] and [13], WHO performance status appeared to be the most important prognostic factor for OS at the time of diagnosis of a DBR. Patients with poor performance status had a median OS of only 3.4 months, despite $60 \%$ (25/42) of patients receiving some form of salvage therapy. The second most important prognostic factor for OS after DBR was the interval between RS and DBR with a longer interval being indicative for longer survival. Based on these two prognostic factors a prognostic classification system (Fig. 3) was derived with median OS of 3.4, 5.4, and 10.3 months for DBR-RPA class III, II, and I, respectively (Fig. 4). As there was a balanced distribution of patients over the prognostic groups, this prognostic classification system could be useful in clinical practice. Though, the unbalanced number of patients having received salvage treatment within the described DBR-RPA classes indicates that performance status and interval between RS and DBR already were important factors for clinical decision making at our department. This may have biased the results of the DBR-RPA classification and this underscores the need for validation of the DBR-RPA in larger groups of patients. 


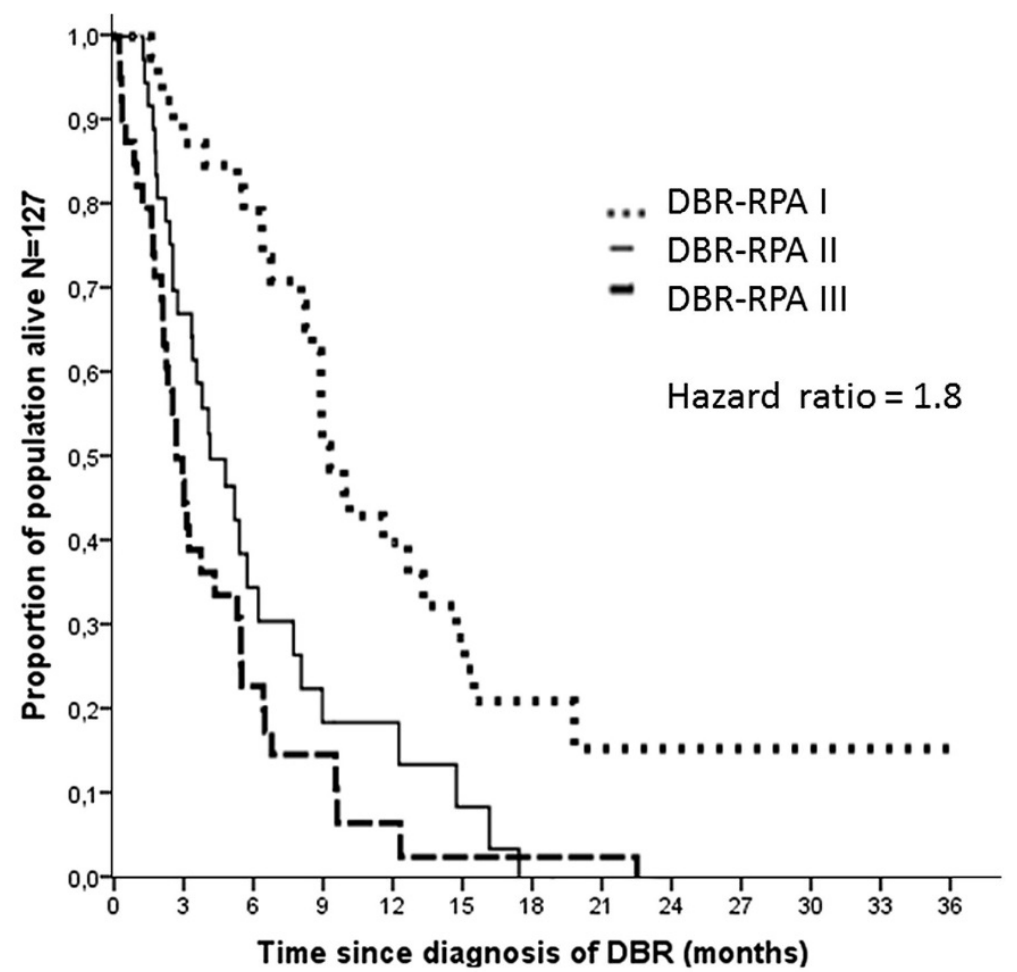

Patients at risk

DBR-RPA I 45

DBR-RPA II 40

DBR-RPA III 42

$\begin{array}{cc}30 & 15 \\ 11 & 4 \\ 11 & 2\end{array}$

5

3

3

3

40

1

0

0

0

Figure 4 Kaplan-Meyer analysis for survival after DBR for DBR-RPA class I, II, and III patients.

Legend: DBR = distant brain recurrence, RPA = recursive partitioning analysis. DBR-RPA class I favorable prognosis with a median OS of 10.3 months, DBR-RPA class II intermediate prognosis with a median OS of 5.4 months, DBR-RPA class III unfavorable prognosis with a median OS of 3.4 months.

Whether salvage treatment should be given at the time of a radiological but asymptomatic presentation of DBR remains unestablished [14]. Although survival after salvage was better for asymptomatic patients, this comparison is biased because these lesions were generally smaller and an absence of extracranial tumor progression may also have influenced the decision to deliver treatment at the asymptomatic stage.

In this study of patients treated with RS alone, only $25 \%$ of treated patients needed salvage treatment for DBR, and ultimately only $18 \%$ of all patients underwent WBRT at any time during follow-up. A three-monthly MRI follow-up scheme identifies DBR at an early stage with respect to size and number of lesions, and most patients are asymptomatic at radiological diagnosis. 


\section{REFERENCES}

[1] Zindler JD, Rodrigues G, Haasbeek CJ, et al. The clinical utility of prognostic scoring systems in patients with brain metastases treated with radiosurgery. Radiother Oncol 2013;106:370-4.

[2] Aoyama $H$, Shirato $H$, Tago $M$, et al. Stereotactic radiosurgery plus whole-brain radiation therapy vs stereotactic radiosurgery alone for treatment of brain metastases - a randomized controlled trial. JAMA 2006;295:2483-91.

[3] Kocher M, Soffietti R, Abacioglu U, et al. Adjuvant whole-brain radiotherapy versus observation after radiosurgery or surgical resection of one to three cerebral metastases: results of the EORTC 2295226001 study. J Clin Oncol 2011;29:134-41.

[4] Hanssens P, Karlsson B, Yeo TT, Chou N, Beute G. Detection of brain micrometastases by high-resolution stereotactic magnetic resonance imaging and its impact on the timing of and risk for distant recurrences Clinical article. J Neurosurg 2011;115:499-504.

[5] Rodrigues G, Zindler J, Warner A, et al. Propensity-score matched pair comparison of whole brain with simultaneous in-field boost radiotherapy and stereotactic radiosurgery. Radiother Oncol 2013;106:206-9.

[6] http://www.acr.org/ /media/ACR/.../guidelines/Stereotactic_Radiosurgery.pdf.

[7] Schemper M, Smith TL. A note on quantifying follow-up in studies of failure time. Contr Clin Trials 1996;17:343-6.

[8] Rodrigues G, Warner A, Zindler J, et al. A clinical nomogram and recursive partitioning analysis to determine the risk of regional failure after radiosurgery alone for brain metastases. Radiother Oncol 2014. pii: S0167-8140(13)00650-6.

[9] Soffietti R, Kocher M, Abacioglu UM, et al. A European organisation for research and treatment of cancer phase III trial of adjuvant whole-brain radiotherapy versus observation in patients with one to three brain metastases from solid tumors after surgical resection or radiosurgery: quality-of-life results. J Clin Oncol 2013;31:65-72.

[10] Chang EL, Wefel JS, Hess KR, et al. Neurocognition in patients with brain metastases treated with radiosurgery or radiosurgery plus whole-brain irradiation: a randomised controlled trial. Lancet Oncol 2009;10:1037-44.

[11] Aoyama H, Tago M, Kato N, et al. Neurocognitive function of patients with brain metastasis who received either whole brain radiotherapy plus stereotactic radiosurgery or radiosurgery alone. Int J Radiat Oncol Biol Phys 2007;68:1388-95.

[12] Tallet AV, Azria D, Barlesi F, Spano JP, Carpentier AF, Gonçalves A, et al. Neurocognitive function impairment after whole brain radiotherapy for brain metastases: actual assessment. Radiother Oncol 2012;7:77.

[13] Nieder C, Mehta MP. Prognostic indices for brain metastases - usefulness and challenges. Radiother Oncol 2009;4:4-10.

[14] Baumann M, Overgaard J. What next? Radiother Oncol 2014;110:1-2. 


\section{Chapter}

\section{Individualized early death and long-term survival prediction after stereotactic radiosurgery for brain metastases of non-small cell lung cancer: two externally validated nomograms}

Zindler JD, Jochems A, Lagerwaard FJ, Beumer R, Troost EG, Eekers DB, Compter I, Van der Toorn PP, Essers M, Oei B, Hurkmans CW, Bruynzeel AM, Bosmans G, Swinnen A, Leijenaar RT; Lambin P. 


\section{ABSTRACT}

Introduction: Commonly used clinical models for survival prediction after stereotactic radiosurgery (SRS) for brain metastases (BMs) are limited by the lack of individual risk scores and disproportionate prognostic groups. In this study, two nomograms were developed to overcome these limitations.

Methods: 495 patients with BMs of NSCLC treated with SRS for a limited number of BMs in four Dutch radiation oncology centers were identified and divided in a training cohort ( $n=214$, patients treated in one hospital) and an external validation cohort $n=281$, patients treated in three other hospitals). Using the training cohort, nomograms were developed for prediction of early death ( $<3$ months) and long-term survival $(>12$ months) with prognostic factors for survival. Accuracy of prediction was defined as the area under the curve (AUC) by receiver operating characteristics analysis for prediction of early death and long term survival. The accuracy of the nomograms was also tested in the external validation cohort.

Results: Prognostic factors for survival were: WHO performance status, presence of extracranial metastases, age, GTV largest BM, and gender. Number of brain metastases and primary tumor control were not prognostic factors for survival. In the external validation cohort, the nomogram predicted early death statistically significantly better ( $p<$ 0.05 ) than the unfavorable groups of the RPA, DS-GPA, GGS, SIR, and Rades 2015 (AUC = 0.70 versus range $A \cup C s=0.51-0.60$ respectively). With an $A \cup C$ of 0.67 , the other nomogram predicted 1 year survival statistically significantly better $(p<0.05)$ than the favorable groups of four models (range AUCs $=0.57-0.61$ ), except for the SIR (AUC $=0.64$, $p=0.34)$. The models are available on www.predictcancer.org.

Conclusion: The nomograms predicted early death and long-term survival more accurately than commonly used prognostic scores after SRS for a limited number of BMs of NSCLC. Moreover these nomograms enable individualized probability assessment and are easy into use in routine clinical practice. 


\section{INTRODUCTION}

Stereotactic Radiosurgery (SRS) is an established treatment for a limited number of brain metastases (BMs) with a maximum diameter up to $4 \mathrm{~cm}$ [1]. To predict survival in BM patients, several prognostic models have been published in the past decades [2-4]. The most commonly used is the Recursive Partitioning Analysis (RPA), which is a relatively simple scoring system, initially developed in patients who were treated with whole brain radiotherapy (WBRT), and subsequently validated for other treatment modalities [5]. RPA classification takes into account age, presence of extracranial metastases, primary tumor control, and performance status. The RPA divides the patient cohort into three prognostic categories; however, a major disadvantage of the RPA is that approximately two-third of patients suitable for SRS will fall in the intermediate prognostic class, and probabilities for both short and long-term survival are group-based and not individualized [2]. Lack of individualized survival probability and disproportional size of prognostic groups were also observed in other more recently published prognostic models for survival, such as the Golden Grading System (GGS), Disease-Specific Graded Prognostic Assessment (DS-GPA), Score Index for Radiosurgery in brain metastases (SIR), and Rades 2015 [2,6-12]. With nomograms, however, it is possible to assess individualized probabilities for endpoints, and relevant prognostic factors can be evaluated. In this study, two validated nomograms were developed for the prediction of early death ( $<3$ months) and long-term ( $>1$ year) survival of patients treated with SRS for a maximum of four BMs of NSCLC. The rationales for these endpoints were that (1) accurate prediction of early death can be relevant for SRS patient selection, and (2) accurate prediction of long-term survival can be particularly useful for the choice of either radical or palliative treatment of extracranial disease $[13,14]$.

\section{MATERIALS AND METHODS}

Data

This multicenter cohort study was approved by the local institutional review board of MAASTRO clinic and registered at ClinicalTrials.gov (NCT02265549). Clinical data were collected from all patients with newly diagnosed BMs treated with linear acceleratorbased SRS between December 2002 and March 2015 in four participating Dutch Radiation Oncology centers: MAASTRO clinic in Maastricht (MC), VU University medical center (VUmc) in Amsterdam, Verbeeten Institute in Tilburg (VT), and Catharina Hospital in Eindhoven (CZE). Patients were generally eligible for SRS if they had a maximum of three BMs, with a maximum diameter of $4 \mathrm{~cm}$, on diagnostic magnetic resonance imaging (MRI) performed by the referring hospital. Prior to treatment, a contrast enhanced high-resolution MRI serving radiation planning purposes was performed with three- 
dimensional distortion correction. If a fourth BM was identified on this planning-MRI, three of the four participating centers also treated these patients with SRS as the single treatment modality. The gross tumor volume (GTV) was defined as the contrast enhancement on the planning-MRI. An isotropic margin of 1-3 mm was used to generate the planning target volume (PTV) [15]. SRS dose was prescribed at the PTV in the range of 15-24 Gy in one to three fractions. Treatment planning in VUmc and CZE have been described previously $[2,15]$. MC used iPlan (Brainlab AG, Feldkirchen, Germany) and Eclipse (Varian, Palo Alto) software, and treatment planning was performed with noncoplanar dynamic conformal arcs or coplanar volumetric modulated arc therapy (VMAT). At VT, the XiO software (Elekta, Stockholm, Sweden) was used for treatment planning, which was accomplished with a non-coplanar static arcs technique or VMAT. During follow-up, MRI scans were acquired every three months; an outpatient visit was planned if both the physical and mental conditions of the patient allowed it.

\section{Variable selection}

A database was available of all patients treated with SRS for newly diagnosed brain metastases of several primary tumors $(n=929)$ in four Dutch hospitals. For this study, patients with BM of NSCLC from whom the date of death was known, or patients with BM of NSCLC who had a follow-up of at least of 1 year were selected ( $n=495)$. In the training cohort $(n=214$ ) Kaplan-Meier analysis including multivariate Cox regression analysis was performed on the baseline characteristics to identify significant prognostic factors for survival. Dependent prognostic factors were excluded from the multivariate analysis: PTV largest BM is dependent on GTV largest BM; cumulative GTV is dependent on GTV largest metastasis; and dose is dependent on GTV largest BM. In the training cohort, the following baseline characteristics were statistically significant prognostic factors for survival in multivariate cox regression analysis: WHO performance status ( $p<$ 0.01 , beta regression coefficient $(b)=0.41$, odds ratio $(O R)=1.50,95 \%$ confidence interval $(95 \% \mathrm{Cl})=1.20-1.88)$, presence of extracranial metastases $(p<0.01, b=0.73$, $\mathrm{OR}=2.08,95 \% \mathrm{Cl}=1.44-3.00)$, age $(p<0.01, b=0.03, \mathrm{OR}=1.03,95 \% \mathrm{Cl}=1.02-1.05)$, GTV largest BM $(p=0.01, b=0.03, O R=1.03,95 \% C l=1.01-1.06)$, and gender $(p=$ $0.04, b=-0.35, O R=0.70,95 \% \mathrm{Cl} 0.51-0.98)$; Other baseline characteristics were not prognostic for survival: primary tumor control $(p=0.98)$, and number of treated BM ( $p$ $=0.18)$.

\section{Nomograms}

The patient cohort treated in the VUmc ( $n=214$ ) was used as the training cohort for development of the two nomograms. The other patient cohort ( $n=281$, patients treated in MC, VT, and CZE) was used as an external validation cohort in which the two developed nomograms were tested independently from the training cohort. Prognostic 
factors for survival identified with Cox multivariate analysis in the training cohort of patients ( $n=214$ ) were used to develop the nomograms for the prediction of early death ( $<3$ months) and long-term survival ( $>1$ year), respectively. Nomograms were made based on logistic regression analysis and learned on the VUmc cohort. The primary endpoint of this study was the area under the curve (AUC) obtained using receiver operating characteristics (ROC) analysis for early death and long-term survival prediction. In the training and validation cohorts, the AUCS of the developed nomogram models were compared with the AUCs of the RPA, DS-GPA, GGS, SIR, and Rades 2015 prognostic models. Comparison of ROC curves was done using DeLong's test for correlated ROC curves. Statistical analyses were performed using SPSS (version 23, IBM, New York), using R (version 3.1.3, R Foundation for Statistical Computing, Vienna, Austria) using the rms, PredictABEL, and pROC packages. Validation was performed according to established methods [16]. Calculating AUC confidence intervals and calibration R2 values (predicted versus observed risk) was done according previously described methods $[17,18]$.

\section{RESULTS}

Median survival of the total cohort of patients ( $n=495)$ was 6.8 months. Baseline characteristics of the training $(n=214)$ and validation $(n=281)$ cohorts are shown in Table 1. The first developed nomogram specific for the prediction of early death is shown in Fig. 1 containing the previously identified prognostic factors for survival. With an AUC of 0.77 , the nomogram predicted early death statistically significantly better than the unfavorable groups of the RPA, DS-GPA, GGS, SIR, and Rades 2015 (range AUC $=0.52-$ 0.59). Similar results were observed in the external validation cohort with an $A \cup C=0.70$ of the nomogram versus range AUCs $=0.51-0.60$ with the other prognostic models, Table 2). For the ROC curves of the nomogram, see Supplementary materials 1. Calibration curves (predicted versus observed probability) of the nomogram are shown in Supplementary materials 2 with R2 values of 0.98 and 0.82 in respectively the training and validation cohort. The independently developed second nomogram is specific for the prediction of long-term survival and shown in Fig. 2 containing the same prognostic factors for survival, but otherwise ranked in the nomogram. With an AUC $=0.77$, this nomogram predicted 1 year survival statistically significantly better than the favorable groups of the RPA, DS-GPA, GGS, SIR, and Rades 2015 in the training cohort (range AUCS $=0.55-0.68$, Table 2). In the external validation cohort comparable results were observed with $A \cup C=0.67$ of the nomogram versus range $A U C s=0.57-0.61, p<0.05$ of four of the five other prognostic models (Table 2). Although the AUC of the nomogram was higher than that of the favorable prognostic group of the SIR $(0.67$ versus $0.64, p=$ 0.34), this difference was not statistically significant. ROC curves of the nomogram are provided in Supplementary materials 3. Calibration curves (predicted versus observed 
probability) of the nomogram are shown in Supplementary materials 4 with R2 values of 0.97 and 0.76 in respectively the training and validation cohort. The training cohort was divided in three equal sized groups based on the probability of 1 year survival as determined by the nomogram. The probability on 1 year survival per patient ranged in the first, second, and third group respectively from $<24 \%, 24-47 \%$, and $>47 \%$. There was a statistically significant difference in survival between the three risk groups in both the training as the validation cohort with Kaplan-Meyer analysis and log-rank test ( $p<$ 0.001, Supplementary materials 5 ). Long term survival over several years was mainly seen in the favorable ( $>47 \%$ one year survival probability) groups of both the training as the validation cohort. Regression coefficients and other characteristics of both the nomogram for early death prediction as the nomogram for long term survival prediction are provided in Supplementary materials 6. 
Table 1 Baseline characteristics of training and validation cohort of 495 patients treated with SRS for BM of NSCLC

\begin{tabular}{|c|c|c|c|}
\hline & & $\begin{array}{l}\text { Training cohort } \\
\mathrm{n}=214\end{array}$ & $\begin{array}{l}\text { External validation cohort } \\
\mathrm{n}=281\end{array}$ \\
\hline \multirow[t]{4}{*}{ Radiation Oncology center } & VUmc & $100 \%$ & $0 \%$ \\
\hline & $\mathrm{MC}$ & $0 \%$ & $55 \%$ \\
\hline & VT & $0 \%$ & $25 \%$ \\
\hline & CE & $0 \%$ & $20 \%$ \\
\hline \multirow[t]{2}{*}{ Gender } & Female & $47 \%$ & $46 \%$ \\
\hline & Male & $53 \%$ & $54 \%$ \\
\hline \multicolumn{2}{|l|}{ Mean age \pm SD (years) } & $63+/-10$ & $63+/-11$ \\
\hline \multirow[t]{3}{*}{ WHO performance score } & 0 or 1 & $83 \%$ & $83 \%$ \\
\hline & 2 & $13 \%$ & $16 \%$ \\
\hline & 3 & $4 \%$ & $1 \%$ \\
\hline \multirow[t]{4}{*}{ Number of BM lesions } & 1 & $66 \%$ & $64 \%$ \\
\hline & 2 & $30 \%$ & $24 \%$ \\
\hline & 3 & $4 \%$ & $11 \%$ \\
\hline & 4 & $0 \%$ & $1 \%$ \\
\hline \multirow[t]{2}{*}{ Extracranial metastases } & Yes & $38 \%$ & $26 \%$ \\
\hline & No & $62 \%$ & $74 \%$ \\
\hline \multirow[t]{2}{*}{ Primary tumor control } & Yes & $41 \%$ & $55 \%$ \\
\hline & No & $59 \%$ & $45 \%$ \\
\hline \multicolumn{2}{|c|}{ Mean GTV of largest BM $\left(\mathrm{cm}^{3}\right) \pm S D$} & $6.8+/-6.6$ & $7.3+/-7.9$ \\
\hline \multirow[t]{3}{*}{ RPA } & Favorable & $30 \%$ & $33 \%$ \\
\hline & Intermediate & $54 \%$ & $60 \%$ \\
\hline & Unfavorable & $16 \%$ & $17 \%$ \\
\hline \multirow[t]{3}{*}{ DS-GPA } & Favorable & $7 \%$ & $11 \%$ \\
\hline & Intermediate & $87 \%$ & $82 \%$ \\
\hline & Unfavorable & $6 \%$ & $7 \%$ \\
\hline \multirow[t]{3}{*}{ GGS } & Favorable & $29 \%$ & $33 \%$ \\
\hline & Intermediate & $67 \%$ & $63 \%$ \\
\hline & Unfavorable & $4 \%$ & $4 \%$ \\
\hline \multirow[t]{3}{*}{ SIR } & Favorable & $29 \%$ & $33 \%$ \\
\hline & Intermediate & $69 \%$ & $65 \%$ \\
\hline & Unfavorable & $2 \%$ & $2 \%$ \\
\hline \multirow[t]{2}{*}{ Rades 2015} & Unfavorable & $24 \%$ & $25 \%$ \\
\hline & Favorable & $76 \%$ & $75 \%$ \\
\hline \multicolumn{2}{|l|}{ Median survival $(95 \% \mathrm{Cl})$} & $6.3(5.0-7.6)$ & $7.0(6.0-8.1)$ \\
\hline \multicolumn{2}{|l|}{ Death at 3 months } & $33 \%$ & $24 \%$ \\
\hline \multicolumn{2}{|l|}{ Alive at 1 year } & $36 \%$ & $30 \%$ \\
\hline
\end{tabular}


Chapter 6

Points

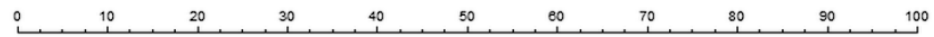

Gender

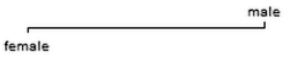

Age

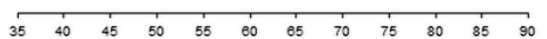

Extracranial metastases

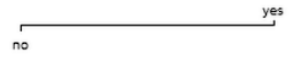

GTV largest metastasis

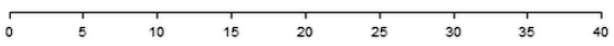

WHO

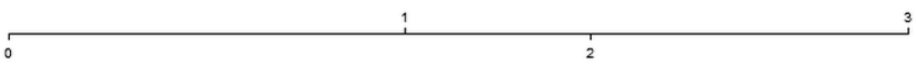

Total Points

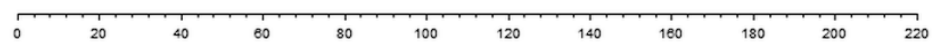

Death in 3 months

\begin{tabular}{lllll}
\hline 0.1 & 0.3 & 0.5 & 0.7 & 0.9
\end{tabular}

Figure 1 Nomogram for prediction of early death based on 214 patients treated with SRS for BM of NSCLC. Legend: $\mathrm{SRS}=$ stereotactic radiosurgery, $\mathrm{BM}=$ brain metastasis, $\mathrm{NSCLC}=$ non-small cell lung cancer, $\mathrm{WHO}=$ World Health Organization performance status, GTV=gross tumor volume, extramets=extracranial metastases

Points

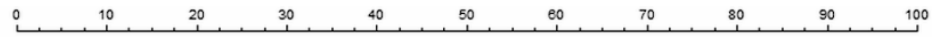

Gender

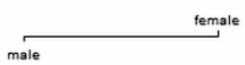

Age

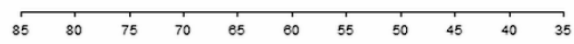

Extracranial metastases

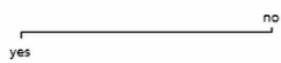

GTV largest metastasis

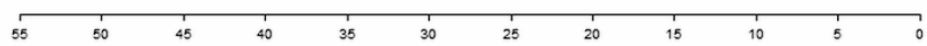

WHO

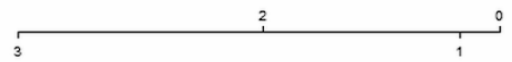

Total Points

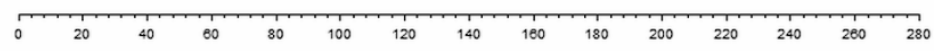

Alive in 1 year

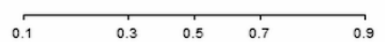

Figure 2. Nomogram for prediction of long-term survival based on outcome of 214 patients treated with SRS alone for BM of NSCLC. Legend: SRS=stereotactic radiosurgery, BM=brain metastasis, NSCLC=non-small cell lung cancer, $W H O=W o r l d ~ H e a l t h$ Organization performance status, GTV=gross tumor volume, extramets=extracranial metastases 
Individualized early death and long-term survival prediction

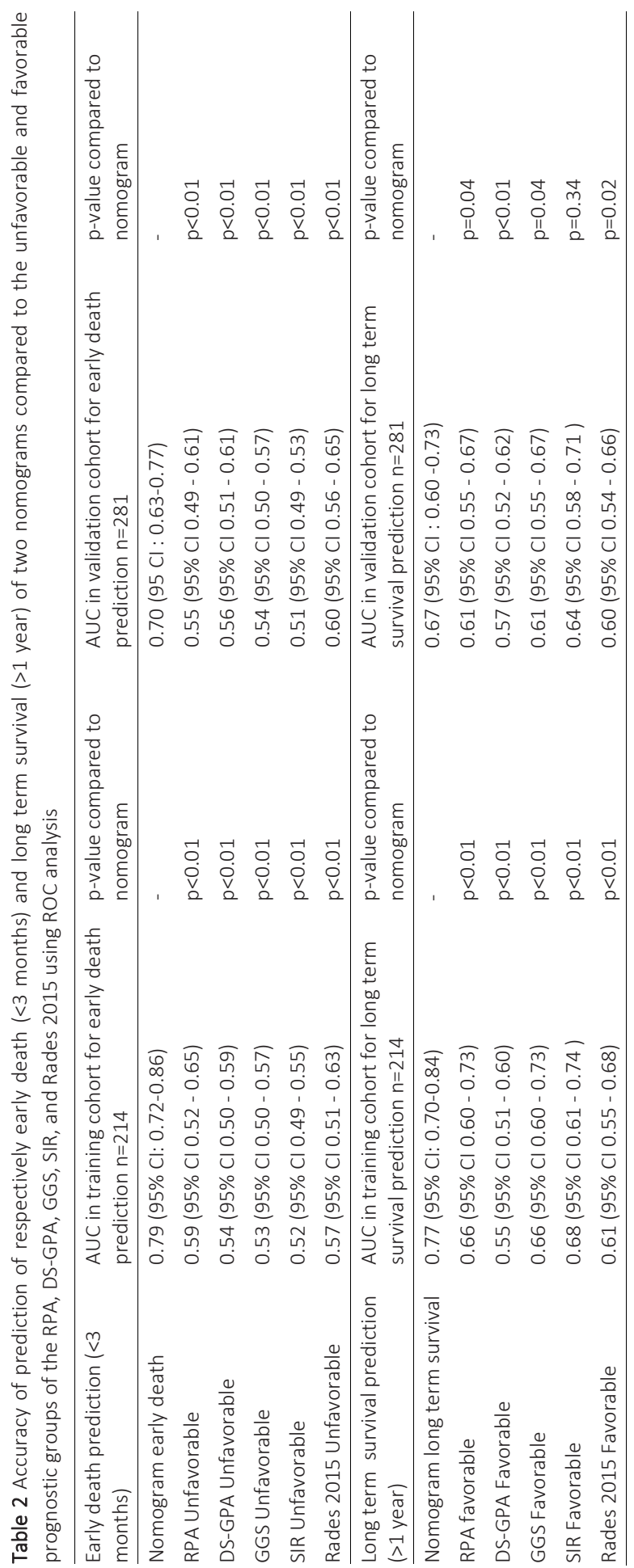




\section{DISCUSSION}

Current published models for the prediction of survival of BM patients treated with SRS have several limitations for clinical applicability, and are mainly limited by the lack of individualized probability assessment. Most published models were developed in or included patients who were treated with other modalities such as WBRT, surgery, or a combination of SRS and WBRT. These models have an unbalanced patient distribution in common, with only a small proportion of patients in the favorable- and unfavorable prognostic category, which are the most relevant for clinical decision making. However, the major limitation is that none of the prognostic models have an individualized probability assessment of survival; rather, they distribute patients only according to a prognostic groups, which is undesirable in the current era of personalized medicine [2]. In this study, nomograms were developed for the prediction of early death $(<3$ months) and long-term survival (>1 year), respectively, in patients treated with SRS for BM of NSCLC. The models were based on and validated in a homogeneous cohort of patients, with a maximum of four BM lesions each, who were treated with SRS alone in four Dutch radiation oncology centers. The nomogram allows for an upfront calculation of the probability of early death and long-term survival on an individual patient basis. Prediction of early death is of relevance for patient selection for SRS to avoid overtreatment of patients. Prediction of long-term survival is of particular relevance when determining extracranial treatment strategies. In patients with a relatively high chance of surviving more than one year, more aggressive therapy for extracranial disease sites may be beneficial to maintain long-term quality of life and disease control $[19,20]$.

Our first nomogram predicts early death more accurately than the unfavorable groups of the RPA, GGS, DS-GPA, SIR, and Rades 2015 in both the training as the validation cohorts. Our second nomogram predicted long term survival more accurately than the favorable groups of the RPA, DS-GPA, GGS, SIR, and Rades 2015 in the training cohort. It has to be noted that in the validation cohort the nomogram predicted long term survival better than the other prognostic models except the SIR. However, the nomogram has still the advantage over the SIR that there is an individualized probability assessment instead of a group based probability assessment. Moreover, the nomogram is easier in use than the SIR in routine clinical practice. It is important to further validate these nomograms in other BM populations treated with SRS, within and outside the Netherlands. Moreover, it is of interest to assess the applicability of these nomogram models for patients with more than four BM lesions, especially as the number of lesions was found not to be an important prognostic factor in patients treated with SRS alone in this study [21].

The choice to only include NSCLC patients in this model was based on the fact that the proportion of other primary tumors was relatively small in our database of in total 929 patients treated with SRS for BM in four Dutch hospitals. Therefore, we questioned the 
applicability of our nomograms for other primary tumors than NSCLC. Combining datasets of patients treated with SRS for BM of other primary tumors than NSCLC may allow the development of predictive models per tumor type. The data to develop models for these outcomes is readily available from centers worldwide. Unfortunately, sharing these data is hampered by political, legal, ethical and administrative boundaries. In order to circumvent these boundaries, a distributed learning approach can be employed [22]. In the distributed learning approach, a model application is sent to each hospital. There, the model learns from the data and is sent back to the modeler. Each locally learned model is combined into a global model that integrates the knowledge of all locally learned models. Using this approach, privacy sensitive patient data never leaves the center. In the future, we intend to use a distributed learning strategy to develop more nomogram models for BM patients.

Despite the use of multiple relevant prognostic factors there is still opportunity for improvement for the accuracy of the nomograms. Further research should focus on improving the accuracy of survival prediction by incorporating additional factors, e.g., using radiographic analysis of the primary tumor or BM (Radiomics), and assessing the value of biomarkers [23-27]. These tools may contribute to more accurate survival prediction, although clinical applicability may be complex and challenging. Therefore, risk assessment based on clinical factors alone remains valuable and relevant for many hospitals that do not have the capacity to perform radiomics and/or biomarker analysis. Accurate prediction of survival, local control, distant brain recurrence, and toxicity is important for patients and clinicians regarding the choice for treatment options; this is also known as shared decision [28-33]. Shared decision will be possible if the patient is informed by individualized probabilities for clear endpoints, such as early death within 3 months and long term survival over 1 year. With these probabilities available and guidance of the physician for interpretation, the patient together with his family may be able to choose between treatment options. The limitations of our study are the retrospective design and the risk of selection bias, although the developed nomograms are based on outcome data in routine clinical practice. These nomograms cannot be used for patients with very large BM of more than $4 \mathrm{~cm}$ in diameter, patients with more than 3 brain metastases, or patients treated with other modalities than SRS alone for newly diagnosed BM of NSCLC. The strength of our study is the external validation of both nomograms.

In conclusion, two novel clinical nomogram models were developed and validated for the prediction of respectively early death ( $<3$ months) and long-term ( $>1$ year) survival after SRS for patients with a maximum of four BMs of NSCLC. These nomogram models can be used for individual probability assessments, and to avoid the limitations of previously published prognostic classification systems. The nomograms can be found at www.predictcancer.org. Supplementary data associated with this article can be found, in the online version, at http://dx.doi.org/10.1016/j.radonc.2017.02.006. 


\section{REFERENCES}

[1] Gijtenbeek JM, Ho VK, Heesters MA, et al. Practice guideline 'Brain metastases' (revision). Ned Tijdschr Geneeskd 2011;155:A4141.

[2] Zindler JD, Rodrigues G, Haasbeek CJ, et al. The clinical utility of prognosticscoring systems in patients with brain metastases treated with radiosurgery. Radiother Oncol 2013;106:370-4.

[3] Nieder C, Mehta MP. Prognostic indices for brain metastases - usefulness and challenges. Radiat Oncol 2009;4:10.

[4] Rodrigues G, Bauman G, Palma D, et al. Systematic review of brain metastases prognostic indices. Pract Radiat Oncol 2013;3:101-6.

[5] Gaspar L, Scott C, Rotman M, et al. Recursive partitioning analysis (RPA) of prognostic factors in three Radiation Therapy Oncology Group (RTOG) brain metastases trials. Int J Radiat Oncol Biol Phys 1997;37:745-51.

[6] Golden DW, Lamborn KR, McDermott MW, et al. Prognostic factors and grading systems for overall survival in patients treated with radiosurgery for brain metastases: variation by primary site. J Neurosurg 2008;109:S77-86.

[7] Sperduto PW, Berkey B, Gaspar LE, et al. A new prognostic index and comparison to three other indices for patients with brain metastases: an analysis of 1,960 patients in the RTOG database. Int J Radiat Oncol Biol Phys 2008;70:510-4.

[8] Sperduto PW, Chao ST, Sneed PK, et al. Diagnosis-specific prognostic factors, indexes, and treatment outcomes for patients with newly diagnosed brain metastases: a multi-institutional analysis of 4,259 patients. Int J Radiat Oncol Biol Phys 2010;77:655-61.

[9] Lorenzoni J, Devriendt D, Massager N, et al. Radiosurgery for treatment of brain metastases: estimation of patient eligibility using three stratification systems. Int J Radiat Oncol Biol Phys 2004;60:218-24.

[10] Rades D, Huttenlocher S, Dziggel L, Blanck O, Hornung D, Mai KT, et al. A new tool to predict survival after radiosurgery alone for newly diagnosed cerebral metastases. Asian Pac J Cancer Prev 2015;16:2967-70.

[11] Weltman E, Salvajoli JV, Brandt RA, et al. Radiosurgery for brain metastases: a score index for predicting prognosis. Int J Radiat Oncol Biol Phys 2000;46:1155-61.

[12] Lagerwaard FJ, Levendag PC, Nowak PJ, et al. Identification of prognostic factors in patients with brain metastases: a review of 1292 patients. Int J Radiat Oncol Biol Phys 1999;43:795-803.

[13] Lambin P, Roelofs E, Reymen B, et al. Rapid Learning health care in oncology - an approach towards decision support systems enabling customized radiotherapy'. Radiother Oncol 2013;109:159-64.

[14] Lambin P, Zindler J, Vanneste B, et al. Modern clinical research: How rapid learning health care and cohort multiple randomised clinical trials complement traditional evidence based medicine. Acta Oncol 2015;54:1289-300.

[15] Seravalli E, van Haaren PM, van der Toorn PP, et al. A comprehensive evaluation of treatment accuracy, including end-to-end tests and clinical data, applied to intracranial stereotactic radiotherapy. Radiother Oncol 2015;116:131-8.

[16] lasonos A, Schrag D, Raj GV, et al. How to build and interpret a nomogram for cancer prognosis. J Clin Oncol 2008;26:1364-70.

[17] DeLong ER, DeLong DM, Clarke-Pearson DL. Comparing the areas under two or more correlated receiver operating characteristic curves: a nonparametric approach. Biometrics 1988;44:837-45.

[18] Madsen AL, Lang M, Kjaerulff UB, Jensen F. The Hugin tool for learning nomograms. In: Symb. Quant. Approaches Reason. Springer; 2003. p. 594-605.

[19] Tree AC, Khoo VS, Eeles RA, et al. Stereotactic body radiotherapy for oligometastases. Lancet Oncol 2013;14:e28-37.

[20] Rekers NH, Troost EG, Zegers CM, et al. Stereotactic ablative body radiotherapy combined with immunotherapy: present status and future perspectives. Cancer Radiother 2014;18:391-5. 
[21] Yamamoto M, Serizawa T, Shuto $T$, et al. Stereotactic radiosurgery for patients with multiple brain metastases (JLGK0901): a multi-institutional prospective observational study. Lancet Oncol 2014;15:387-95.

[22] Lambin P, Zindler J, Vanneste BG, et al. Decision support systems for personalized and participative radiation oncology. Adv Drug Deliv Rev 2016 [pii: S0169-409X(16)30008-4].

[23] Aerts HJ, Velazquez ER, Leijenaar RT, et al. Decoding tumour phenotype by noninvasive imaging using a quantitative radiomics approach. Nat Commun 2014;5:4006.

[24] Coroller TP, Grossmann P, Hou Y, et al. CT-based radiomic signature predicts distant metastasis in lung adenocarcinoma. Radiother Oncol 2015;114:345-50.

[25] Panth KM, Leijenaar RT, Carvalho S, et al. Is there a causal relationship between genetic changes and radiomics-based image features? An in vivo preclinical experiment with doxycycline inducible GADD34 tumor cells. Radiother Oncol 2015;116:462-6.

[26] Parmar C, Grossmann P, Bussink J, et al. Machine learning methods for quantitative radiomic biomarkers. Sci Rep 2015;5:13087.

[27] Leijenaar RT, Nalbantov G, Carvalho S, et al. The effect of SUV discretization in quantitative FDG-PET Radiomics: the need for standardized methodology in tumor texture analysis. Sci Rep 2015;5:11075.

[28] Oberije C, Nalbantov G, Dekker A, et al. A prospective study comparing the predictions of doctors versus models for treatment outcome of lung cancer patients: A step toward individualized care and shared decision making. Radiother Oncol 2014;112:37-43.

[29] Lambin P, van Stiphout RG, Starmans MH, et al. Predicting outcomes in radiation oncologymultifactorial decision support systems. Nat Rev Clin Oncol 2013;10:27-40.

[30] West C, Azria D, Chang-Claude J, et al. The REQUITE project: validating predictive models and biomarkers of radiotherapy toxicity to reduce sideeffects and improve quality of life in cancer survivors. Clin Oncol ( $R$ Coll Radiol) 2014;26:739-42.

[31] Lambin P, Rios-Velazquez E, Leijenaar R, et al. Radiomics: Extracting more information from medical images using advanced feature analysis. Eur J Cancer 2012;48:441-6.

[32] Stacey D, Légaré F, Col NF, et al. Decision aids for people facing health treatment or screening decisions. Cochrane Database Syst Rev 2014;1: CD001431.

[33] Zindler JD, Thomas CR Jr, Hahn SM, et al. Increasing the Therapeutic Ratio of Stereotactic Ablative Radiotherapy by Individualized Isotoxic Dose Prescription. J Natl Cancer Inst 2015 Oct 16;108(2). pii: djv305 

Chapter

Postoperative management after resection of a single brain metastasis: whole brain radiotherapy, local radiotherapy, or 'wait and scan'?

Dutch Journal of Oncology 2013;10(8):318-23

Zindler JD, Gijtenbeek JMM, Lagerwaard FJ. 


\section{ABSTRACT}

The optimal policy following total resection of a single brain metastasis remains a matter of debate. Randomized studies, such as the recently published EORTC study 2295226001, have confirmed the lack of a survival benefit of postoperative whole brain radiotherapy (WBRT) in comparison to observation; nor did WBRT improve the survival with functional independency. The benefit of WBRT appeared to be a decrease in neurological death, as a result of a diminished risk of local relapses at the site of the resection and a decreased incidence of new metastases elsewhere in the brain. This advantage of WBRT has to be weighed against early and late potential side effects of this approach. The above results have led a growing number of Dutch centers to adapt their policy towards either 'wait and scan' or local radiotherapy to the resection cavity. This paper discusses the results of the EORTC study in more detail, as well as possible further randomized studies including local radiotherapy in this setting, which have already been initiated in the United States.

\section{SAMENVATTING}

Het postoperatieve beleid na een totale resectie van een hersenmetastase staat ter discussie. Gerandomiseerde studies, waaronder de recentelijk gepubliceerde EORTC 22952-26001-studie, hebben bevestigd dat de tot voorheen standaard uitgevoerde totale schedelbestraling geen overlevingswinst oplevert ten opzichte van observatie gevolgd door behandeling van een eventueel recidief, noch een winst in de duur dat patiënt in een goede conditie verkeert. Het voordeel van totale schedelbestraling bestaat uit een verlaging van de kans op overlijden door een neurologische oorzaak als gevolg van een vermindering van het risico op een lokaal recidief in de resectieholte en een kleinere kans op het ontwikkelen van nieuwe metastasen elders in de hersenen. Dit voordeel dient te worden afgewogen tegen de mogelijke vroege en late bijwerkingen van totale schedelbestraling. De bovengenoemde resultaten hebben geleid tot een verandering van het postoperatieve beleid in vele Nederlandse centra, waarbij in toenemende mate ofwel een 'wait and scan'-beleid ofwel lokale bestraling op de resectieholte wordt toegepast. In dit artikel worden de resultaten van de gepubliceerde EORTCstudie in meer detail besproken. Ook worden mogelijke gerandomiseerde vervolgstudies met onder andere lokale bestraling van de resectieholte besproken, zoals de studies die in de Verenigde Staten inmiddels zijn opgestart. 


\section{INLEIDING}

Hersenmetastasen zijn een belangrijke oorzaak voor morbiditeit en mortaliteit bij patiënten met kanker. De onderliggende primaire tumor bij hersenmetastasen is meestal longcarcinoom of mammacarcinoom, maar kan ook niercelcarcinoom, melanoom of een andere maligniteit zijn.[1] De indicatie voor de verschillende behandelingsmogelijkheden wordt beschreven in de recentelijk geactualiseerde Nederlandse richtlijn over de diagnostiek en behandeling van hersenmetastasen.[2]Bij patiënten in een goede conditie met beperkte of behandelbare extracraniële ziekte is totale schedelbestraling ('whole brain radiotherapy'; WBRT) of stereotactische radiochirurgie (SRS) de behandeling van keuze met als doel om progressie van neurologische symptomen of overlijden ten gevolge van neurologische uitval te voorkomen. De Nederlandse richtlijn beschrijft een geselecteerde groep patiënten waarbij resectie van hersenmetastasen de voorkeur heeft. Meestal gaat het om een enkelvoudige hersenmetastase, waarbij een histologische diagnose dient te worden verkregen die een significant massa-effect vertoont of te groot is om voor SRS in aanmerking te komen. Sinds eind jaren 90 van de vorige eeuw bestaat een controverse of een totale resectie van een enkelvoudige hersenmetastase routinematig moet worden gevolgd door adjuvante WBRT om microscopisch achtergebleven ziekte in de resectieholte en elders in de hersenen te behandelen.[3-7] De verkregen winst in intracraniële controle moet worden afgezet tegen de potentiële bijwerkingen van WBRT op korte en lange termijn, naast de beschikbaarheid van verschillende salvagetherapieën voor recidiefmetastasen in de hersenen. Op basis van de eerste gerandomiseerde studie tussen chirurgie met of zonder postoperatieve WBRT, gerapporteerd door Patchell et al. in 1998, is adjuvante WBRT op basis van een significant betere lokale controle lange tijd de standaardbehandeling geweest in de meeste Nederlandse centra.[8] In deze studie werd geen winst in overleving gevonden tussen beide groepen. Deze studie was echter ook niet gepowered om een overlevingsvoordeel aan te tonen. De publicatie van de recente EORTC-studie 22952-26001 heeft de discussie over het nut van adjuvante WBRT opnieuw doen oplaaien. $[9,10]$ Op basis van de resultaten van deze gerandomiseerde studie, die hierna zullen worden beschreven, is een toenemend aantal centra inmiddels overgegaan op een 'wait and scan'-beleid of uitsluitend lokale adjuvante radiotherapie op de resectieholte. In dit artikel wordt dieper ingegaan op de verschillende adjuvante beleidsmogelijkheden na resectie van een enkele hersenmetastase. 
Tabel 1 Gerandomiseerde fase III studies met betrekking tot postoperatieve WBRT

\begin{tabular}{|c|c|c|c|c|c|}
\hline & $\begin{array}{l}\text { Absolute } \\
\text { overleving } \\
\text { (maanden) }\end{array}$ & $\begin{array}{l}\text { Overleving in } \\
\text { goede conditie } \\
\text { (maanden) }\end{array}$ & $\begin{array}{l}\text { Vrij van } \\
\text { neurologisch } \\
\text { overlijden }\end{array}$ & Lokale controle & $\begin{array}{l}\text { Vrij van nieuwe } \\
\text { metastasen }\end{array}$ \\
\hline $\begin{array}{l}\text { Patchell } \\
\mathrm{NCH} \text { alleen } \\
\mathrm{NCH}+\text { WBRT }\end{array}$ & $\begin{array}{l}10 \\
11 \text { (niet sign) }\end{array}$ & 8 vs. 9 n.s. & $56 \%$ vs. $86 \%$ & $54 \%$ vs. $90 \%$ & $63 \%$ vs. $86 \%$ \\
\hline $\begin{array}{l}\text { Kocher } \\
\mathrm{NCH} \text { alleen vs } \\
\mathrm{NCH}+\text { WBRT }\end{array}$ & $\begin{array}{l}11 \\
11 \text { (niet sign) }^{\star}\end{array}$ & 10 vs. 10 n.s. ${ }^{*}$ & $56 \%$ vs. $72 \%^{\star}$ & $41 \%$ vs. $73 \%$ & $58 \%$ vs. $77 \%$ \\
\hline
\end{tabular}

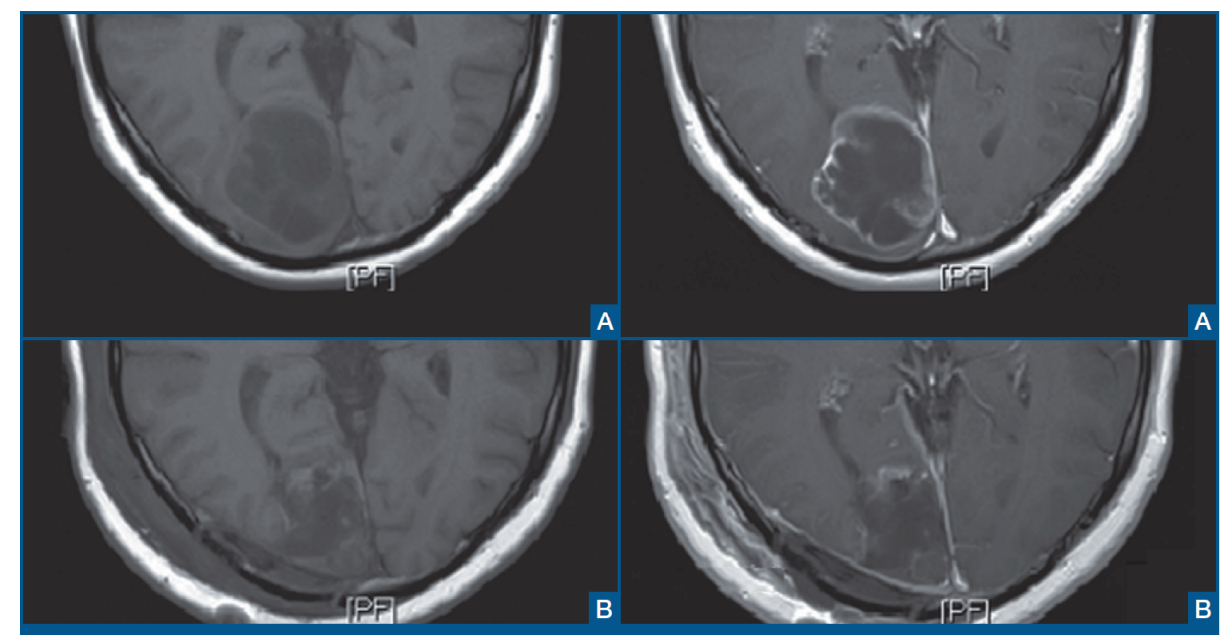

Figuur 1 Pre- en post-operatieve MRI na subtotale resectie van een hersenmetastase.

Pre-operatieve (1A) en post-operatieve MRI cerebrum (1B) met en zonder gadoliniumcontrast van een gereserceerde enkele hersenmetastase van een niet-kleincellig longcarcinoom bij een 39 jarige man. Ventraal in de resectieholte aankleurend gebied verdacht voor resttumor (1B).

\section{'WAIT AND SCAN' VERSUS WBRT NA TOTALE RESECTIE VAN EEN ENKELE HERSENMETASTASE}

Bij een 'wait and scan'-beleid wordt afgezien van een adjuvante behandeling na een macroscopisch totale resectie van een enkelvoudige hersenmetastase en wordt volstaan met routinematige MRI-follow-up (vaak driemaandelijks) om een eventueel recidief in het operatiegebied of elders in de hersenen vroegtijdig op het spoor te komen. Van belang voor de keuze van dit beleid is het bevestigen van de volledigheid van de resectie op basis van het operatieverslag en een vroeg (binnen 72 uur) postoperatief vervaardigde $\mathrm{MRI}$-scan met contrast; in de meeste centra behorend bij het standaard- 
beleid. Aanwijzingen voor resttumor in de operatieholte zal vrijwel altijd een indicatie voor aanvullende behandeling zijn, meestal radiotherapie of re-resectie. Overigens werd in de recente EORTC-studie postoperatieve beeldvorming bij slechts $74 \%$ van de patiënten verricht. In de overige gevallen werd afgegaan op de inschatting van de radicaliteit door de neurochirurg.9 Het 'wait and scan'-beleid na een radiologisch bevestigde totale resectie wordt ondersteund door de bevindingen van de 2 gerandomiseerde studies naar het effect van adjuvante bestraling, waarbij in geen van beide studies een overlevingsvoordeel of verbetering van functioneel onafhankelijke overleving werd waargenomen.[8,9] De kans op een lokaal recidief in of nabij de resectieholte na een 'wait and scan'-beleid is echter aanzienlijk en werd gezien bij respectievelijk $46 \%$ en $59 \%$ van de patiënten in de Patchell- en EORTC-studie. De winst van postoperatieve WBRT werd vooral gezien in de secundaire eindpunten van de gerandomiseerde studies. Er was sprake van een vermindering van de kans op overlijden als gevolg van neurologische progressie; in de Patchell-studie van 44\% na 'wait and scan' naar $14 \%$ met WBRT en in de EORTC-studie van 44\% naar 28\% met WBRT. Daarnaast was er een significante vermindering van het recidiefpercentage na WBRT. De lokale controle verbeterde van $54 \%$ naar $90 \%$ en van $41 \%$ naar $73 \%$ met WBRT bij respectievelijk de Patchell- en de EORTC-studie, terwijl de kans op het ontwikkelen van metastasen elders in de hersenen afnam van $37 \%$ naar $14 \%$ in de Patchell-studie en van $42 \%$ naar $23 \%$ in de EORTCstudie (zie Tabel 1). Een belangrijke afweging voor het interpreteren van bovenstaande bevindingen wordt gevormd door de mogelijke toxiciteit van WBRT op korte en lange termijn. Vroege bijwerkingen van WBRT zijn haaruitval, vermoeidheid en lusteloosheid, terwijl op de lange termijn vooral het risico op neurocognitieve achteruitgang van belang is.[11,12] De met chirurgie behandelde groep patiënten vormt over het algemeen juist een gunstig geselecteerde groep patiënten met een mediane overleving van rond 1 jaar en daarom zijn met name langetermijneffecten van belang. [8,9] Begin 2013 zijn de resultaten van een subanalyse van de EORTC-studie naar de kwaliteit-vanlevengegevens gepubliceerd.10 Patiënten die adjuvante WBRT kregen na een resectie van hersenmetastasen hadden op meerdere tijdstippen, maar met name in de eerste maanden na resectie, een slechtere kwaliteit van leven dan patiënten die geen adjuvante WBRT kregen. De belangrijkste uitkomsten waren dat de WBRT-groep 8 weken na de behandeling vermoeider was en fysiek slechter functioneerde en 9 maanden na de behandeling een slechtere algehele gezondheid had. Na 12 maanden had de WBRTgroep een significant slechtere cognitie op basis van geheugenproblemen (gemiddelde EORTC QLQ-C30-cognitiescore van 80,4 in de observatiegroep versus 69,7 in de WBRTgroep). 


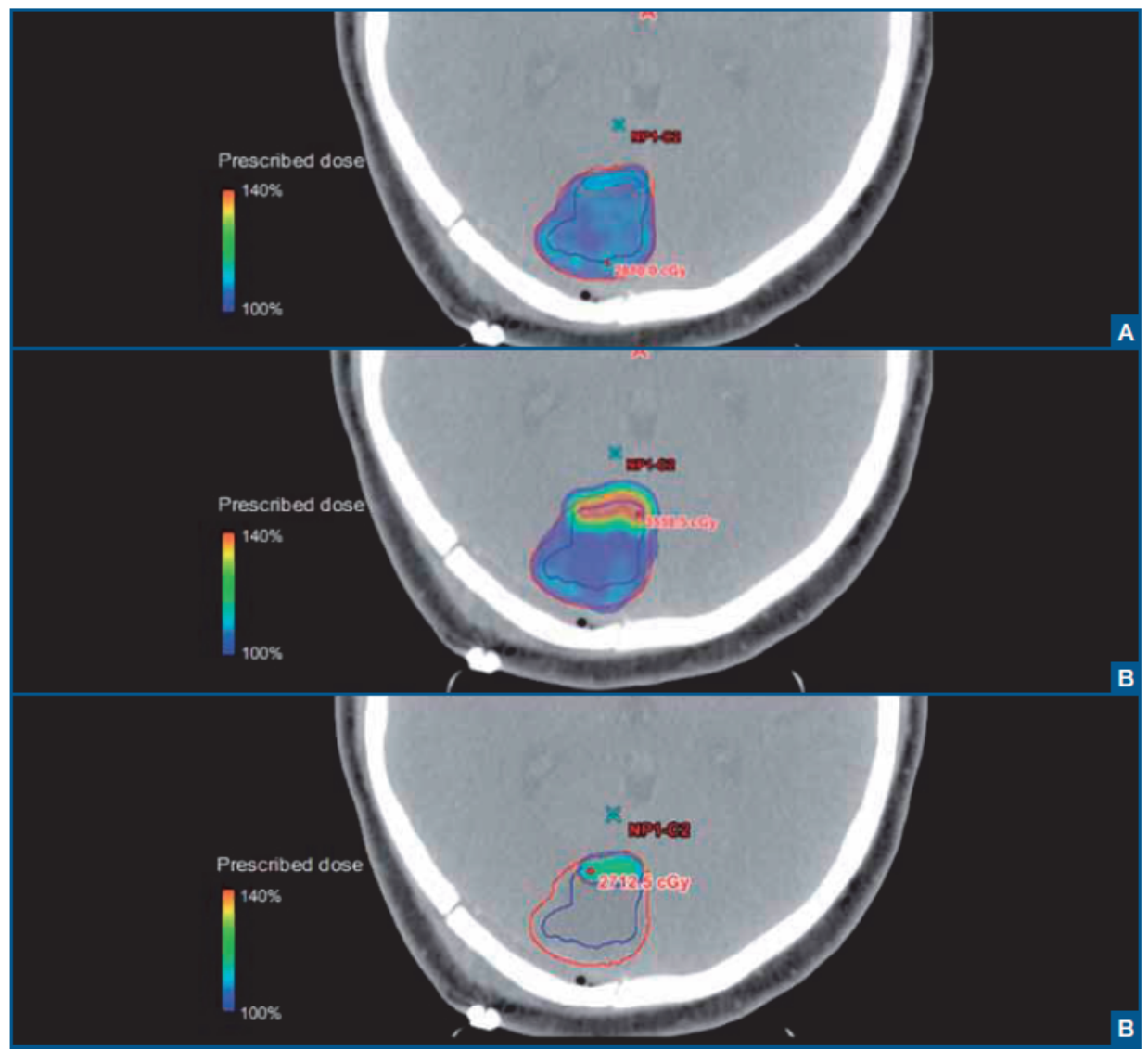

Figuur 2 Voorbeelden van bestralingsplannen van lokale radiotherapie na subtotale resectie van een hersenmetastase. Drie voorbeelden van een mogelijk bestralingsplan van lokale radiotherapie op de resectieholte geprojecteerd op een post-operatieve CT van de patiënt uit Figuur 1. Bij Figuur 2A wordt de dosisverdeling getoond van 5 fracties van 5 Gy tot een totaaldosis van 25 Gy gedoseerd op de rand van het doelgebied (rode lijn). Het plan heeft een relatief homogene dosisverdeling. Bij figuur 2B wordt een geïntegreerde boost gegeven op de resttumor ventraal in de resectieholte ( 5 fracties van 6 Gy tot een totaaldosis van 30 Gy) en het overige doelgebied krijgt 5 fracties van 5 Gy tot een totaaldosis van 25 Gy (100\% voorgeschreven dosis is 25 Gy). Bij figuur 2C wordt een eenmalige fractie van $21 \mathrm{~Gy}$ op alleen de resttumor gegeven.

\section{LOKALE RADIOTHERAPIE ALS ALTERNATIEF}

Een toenemend aantal recente publicaties beschrijft het toepassen van postoperatieve lokale radiotherapie op de resectieholte, met als doel enerzijds om de lokale controle te optimaliseren en anderzijds om de potentiële bijwerkingen van WBRT te voorkomen. Op incidenteel toegepaste technieken, zoals neoadjuvante radiochirurgie of intraoperatieve brachytherapie, wordt in dit artikel niet ingegaan.[13,14] Een recent overzichtsartikel van Roberge et al. beschrijft de preliminaire resultaten van voornamelijk 
retrospectieve studies naar de waarde van radiochirurgie of gefractioneerde stereotactische radiotherapie op de resectieholte.[15] Hoewel er een variatie bestaat in de verschillende publicaties in de definitie van het doelgebied (vrijwel altijd de resectierand met een marge van enkele millimeters; zie Figuur 1 en 2) en de gebruikte dosis, lijkt de lokale controle na postoperatieve lokale radiotherapie, zoals ook verwacht, minstens even goed als beschreven in de chirurgie plus WBRT-groep van de eerdere studies. Het gewogen gemiddelde van de beschreven studies voor lokale controle bedraagt ongeveer $85 \%$ na 1 jaar. Het risico op symptomatische radionecrose wordt geschat op 0-6\%, afhankelijk van de gebruikte bestralingsdosis. In vervolg op de recentelijk afgesloten EORTC-studie wordt op dit moment een aantal prospectief gerandomiseerde studies met lokale radiotherapie in een van de onderzoeksgroepen verricht. Met name de lopende N107C-studie, waarbij wordt gerandomiseerd tussen postoperatieve WBRT en radiochirurgie op de resectieholte bij patiënten met 1-4 hersenmetastasen, verdient hier vermelding.[16] Deze studie beoogt een totaal van 192 patiënten te includeren en heeft als hoofdeindpunten neurocognitief functioneren en overleving. Het zal echter nog enige jaren duren voordat de resultaten van deze studie bekend zullen zijn.

\section{BELEID NA INCOMPLETE RESECTIE VAN EEN ENKELE HERSENMETASTASE}

Het beleid na een incomplete resectie van een hersenmetastase is niet goed beschreven in de literatuur, maar in het algemeen zal hierbij vrijwel altijd tot aanvullende behandeling (re-resectie, adjuvante radiotherapie) worden besloten. In het geval van adjuvante radiotherapie zijn er meerdere mogelijkheden; WBRT (met of zonder een 'surdosage' op de resectieholte) of uitsluitend lokale bestraling. De meest eenvoudige manier is om adjuvante lokale radiotherapie te geven op de gehele resectieholte inclusief de tumorrest, zoals beschreven na een complete resectie. Daarnaast is het mogelijk om uitsluitend de resttumor (stereotactisch) te bestralen (zie Figuur 1 en 2), ofwel de gehele resectieholte met een geïntegreerde 'surdosage' op de resttumor. Welke van deze lokale bestralingstechnieken de voorkeur verdient is onduidelijk en zal per patiënt en per instituut verschillen; verreweg de meeste Nederlandse radiotherapie instituten kunnen tegenwoordig dit soort precisiebestralingen uitvoeren.

\section{CONCLUSIE}

Sinds de publicatie van de recente EORTC-studie staat het beleid na een (bevestigde) complete resectie van een enkele hersenmetastase opnieuw ter discussie. De overleving na 'wait and scan' of totale schedelbestraling was in beide groepen gelijk. Het risico op een recidief in de hersenen was echter significant kleiner na schedelbestraling. Op basis van deze resultaten zijn beide strategieën postoperatief verdedigbaar. De waarde 


\section{Chapter 7}

van lokale radiotherapie op de resectieholte is vooralsnog onbekend, maar gepubliceerde resultaten van retrospectieve studies laten een lokale controle op de resectieholte zien die minstens even goed is als beschreven na totale schedelbestraling. Het valt te verwachten dat met lokale bestraling de kans op langetermijneffecten, die bij totale schedelbestraling wel worden gezien, kunnen worden vermeden. Lopende gerandomiseerde studies zullen hierover in de toekomst uitsluitsel geven. 


\section{REFERENTIES}

[1] Sperduto PW, Chao ST, Sneed PK, et al. Diagnosis-specific prognostic factors, indexes, and treatment outcomes for patients with newly diagnosed brain metastases: a multi-institutional analysis of 4,259 patients. Int J Radiat Oncol Biol Phys 2010;77:655-61.

[2] Gijtenbeek JM, Ho VK, Heesters MA, et al. Practice guideline 'Brain metastases' (revision). Ned Tijdschr Geneeskd 2011;155:A4141.

[3] Peacock KH, Lesser GJ. Current therapeutic approaches in patients with brain metastases. Curr Treat Options Oncol 2006;7:479-89.

[4] Iwadate $Y$, Namba H, Yamaura A. Whole-brain radiation therapy is not beneficial as an adjuvant therapy for brain metastases compared with localized irradiation. Anticancer Re 2002;22:325-30.

[5] Tsao MN, Lloyd NS, Wong RK. Clinical practice guideline on the optimal radiotherapeutic management of brain metastases. Supportive Care Guidelines Group of Cancer Care Ontario's Program in Evidence-based Care.BMC Cancer 2005;5:34.

[6] Bajaj GK, Kleinberg L, Terezakis S. Current concepts and controversies in the treatment of parenchymal brain metastases: improved outcomes with aggressive management. Cancer Invest 2005;23:363-76.

[7] Vogelbaum MA, Suh JH. Resectable brain metastases. J Clin Oncol 2006;24:1289-94.

[8] Patchell RA, Tibbs PA, Regine WF, et al. Postoperative radiotherapy in the treatment of single metastases to the brain: a randomized trial. JAMA 1998;280:1485-9.

[9] Kocher M, Soffietti R, Abacioglu U, et al. Adjuvant whole-brain radiotherapy versus observation after radiosurgery or surgical resection of one to three cerebral metastases: results of the EORTC 2295226001 study. J Clin Oncol 2011;29:134-41.

[10] Soffietti R, Kocher M, Abacioglu UM, et al. A European Organisation for Research and Treatment of Cancer phase III trial of adjuvant whole-brain radiotherapy versus observation in patients with one to three brain metastases from solid tumors after surgical resection or radiosurgery: quality-of-life results. J Clin Oncol 2013;31:65-72.

[11] Chow E, Davis L, Holden L, Tsao M, et al. Prospective assessment of patient-rated symptoms following whole brain radiotherapy for brain metastases. J Pain Symptom Manage 2005;30:18-23.

[12] McDuff SG, Taich ZJ, Lawson JD, et al. Neurocognitive assessment following whole brain radiation therapy and radiosurgery for patients with cerebral metastases. J Neurol Neurosurg Psychiatry 2013 May 28

[13] Yamamoto M, Kawabe T, Barfod BE, et al. Can pre-operative GKRS prevent meningeal dissemination in brain met patients? A casematched study. Presented at the 10th Biennial Congress and Exhibition of the International Stereotactic Radiosurgery Society - May 8-12-2011, Paris France.

[14] Huang K, Sneed PK, Kunwar S, et al. Surgical resection and permanent iodine-125 brachytherapy for brain metastases. J Neurooncol 2009;91:83-93.

[15] Roberge D, Parney I, Brown PD. Radiosurgery to the postoperative surgical cavity: who needs evidence? Int J Radiat Oncol Biol Phys 2012;83:486-93.

[16] www.clinicaltrials.gov. 



\section{Chapter}

\section{Whole brain radiotherapy versus Stereotactic Radiosurgery for 4 - 10 brain metastases: a phase III randomized multicenter trial}

BMC Cancer 2017 Jul 25;17(1):500

Zindler JD, Bruynzeel AME, Eekers DBP, Hurkmans CW, Swinnen A, Lambin P 


\section{ABSTRACT}

Background Maintenance of quality of life is the primary goal during treatment of brain metastases (BM). This is a protocol of an ongoing phase III randomized multicenter study. This study aims to determine the exact additional palliative value of stereotactic radiosurgery (SRS) over whole brain radiotherapy (WBRT) in patients with 4-10 BM.

Methods The study will include patients with 4-10 BM from solid primary tumors diagnosed on a high-resolution contrast-enhanced MRI scan with a maximum lesional diameter of $2.5 \mathrm{~cm}$ in any direction and a maximum cumulative lesional volume of $30 \mathrm{~cm}^{3}$. Patients will be randomized between WBRT in five fractions of 4 Gy to a total dose of 20 Gy (standard arm) and single dose SRS to the BMs (study arm) in the range of 15-24 Gy. The largest BM or a localization in the brainstem will determine the prescribed SRS dose. The primary endpoint is difference in quality of life (EQ5D EUROQOL score) at 3 months after radiotherapy with regard to baseline. Secondary endpoints are difference in quality of life (EQ5D EUROQOL questionnaire) at 6, 9 and 12 months after radiotherapy with regard to baseline. Other secondary endpoints are at 3, 6, 9 and 12 months after radiotherapy survival, Karnofsky $\geq 70$, WHO performance status, steroid use (mg), toxicity according to CTCAE V4.0 including hair loss, fatigue, brain salvage during followup, type of salvage, time to salvage after randomization and Barthel index. Facultative secondary endpoints are neurocognitive function assessed with the Hopkins verbal learning test revised, quality of life EORTC QLQ-C30, quality of life EORTC BN20 brain module and fatigue scale EORTC QLQ-FA13.

Discussion Worldwide, most patients with more than 4 BM will be treated with WBRT. Considering the potential advantages of SRS over WBRT, i.e. limiting radiation doses to uninvolved brain and a high rate of local tumor control by just a single treatment with fewer side effects, such as hair loss and fatigue, compared to WBRT, SRS might be a suitable alternative for patients with 4-10 BM.

Trial registration www.clinicaltrials.gov: NCT02353000, trial registration date 15th January 2015, open for accrual 1st July 2016, nine patients were enrolled in this trial on 14th April 2017. 


\section{BACKGROUND}

In this randomized study, in patients with 4-10 brain metastases (BM), the standard treatment of whole brain radiotherapy (WBRT) is compared to stereotactic radiosurgery (SRS) for all lesions with the primary endpoint of quality of life (QOL) at 3 months after radiotherapy. We hypothesize that SRS provides better QOL than WBRT because of better local tumor control and avoidance of potential side effects of WBRT. Brain metastases are an important cause of morbidity and mortality in patients with metastasized cancer, and therefore, optimal tumor control is essential. Dutch guideline recommends SRS for patients with 1-3 BM and WBRT for patients with 4 or more BM. WBRT has side effects such as hair loss, fatigue and cognitive dysfunction, which may result in decreased QOL that is undesirable in a palliative setting.[1] There are important advantages of SRS over WBRT, i.e., limiting radiation doses to the uninvolved brain and a high rate of local tumor control by just a single treatment compared to WBRT, in which a relatively low palliative radiation dose is delivered to both the brain and the BM (Figure 1). SRS is widely available in most Dutch radiotherapy centers. Because of recent technical advances, SRS can be delivered in relatively short treatment time in 10-45 min in patients with multiple BM. With SRS, there is a relatively low risk (?5\%) of symptomatic radionecrosis: damage of the surrounding brain tissue, which may occur several months after treatment. Radionecrosis may cause neurologic symptoms, often temporary, which are treated with dexamethasone. Moreover, the clinical value of WBRT over the best supportive care is controversial. A recent interim analysis of the QUARTZ study showed equal QOL and survival for patients treated with WBRT versus treatment with steroids alone. [2] A recent (non-randomized) study in a large cohort of patients with BM showed that after SRS, survival of patients with 5-10 BM was comparable to that of patients treated with 2-4 BM.[3] Thus far, WBRT has never been compared directly with SRS in patients with 4-10 BM, and therefore a randomized trial is needed. In the United States, the NAGKC 12-01 (NCT01731704) was initiated in patients with 5 or more brain metastases in which SRS was directly compared with WBRT. However, this study was closed prior to enrolment of patients because of insufficient staff. Many systemic therapies do not have satisfactory tumor control of BM because of poor passage of the blood brain barrier. In the future, SRS may be the optimal treatment choice to control $\mathrm{BM}$ and in patients with multiple brain metastases to maintain long-term QOL, whereas new innovative systemic therapies may control extracranial disease. 


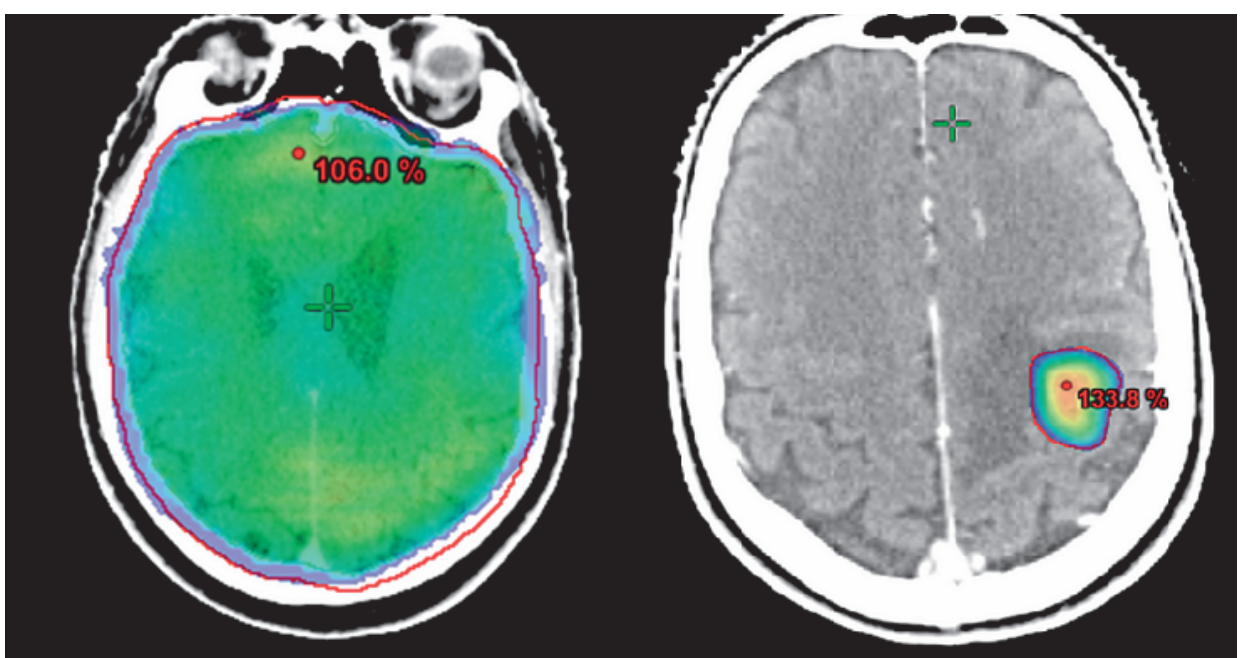

Figure 1 Dose distribution difference between WBRT (left) and SRS (right). Legend: figure 1 A typical dose distribution on a planning-CT of WBRT on the left side and of SRS on the right side. With WBRT, the healthy brain tissue receives the same low palliative radiation dose (non-ablative). With SRS, only the metastatic tissue receives a high ablative dose.

\section{METHODS/DESIGN}

\section{Design}

The study is a randomized phase III study with two study arms. The standard arm is WBRT and the experimental arm is SRS. We hypothesize that SRS provides better QOL than WBRT because of better local tumor control and avoidance of potential side effects of WBRT.

\section{Objectives and endpoints}

The primary objective is to determine whether QOL is better preserved after SRS than after WBRT in patients with 4-10 BM. The primary endpoint is difference in QOL (EQ5D EUROQOL score) at 3 months after radiotherapy with regard to baseline. The secondary objective is to determine whether SRS provides better survival and less toxicity than WBRT.[1,2] Secondary endpoints are difference in QOL (EQ5D EUROQOL questionnaire) at 6, 9 and 12 months after radiotherapy with regard to baseline. Survival at 3, 6, 9 and 12 months after radiotherapy, Karnofsky $\geq 70$, WHO performance status, steroid use (mg), toxicity according CTCAE V4.0 including hair loss, fatigue, neurocognitive function and brain salvage during follow-up, type of salvage, time to salvage after randomization and Barthel index. Facultative secondary endpoints are neurocognitive function with 
the Hopkins verbal learning test, quality of life EORTC QLQ-C30, quality of life EORTC BN20 brain module and fatigue scale EORTC QLQ-FA13.

\section{Study population}

The study will include patients with 4-10 BM from solid tumors diagnosed on a high resolution contrast-enhanced $\mathrm{MRI}$ scan referred for radiotherapy, with a maximum lesional diameter of $2.5 \mathrm{~cm}$. Before randomization, a new neuronavigation MRI (T1 gadolinium) is made for the definitive evaluation of the inclusion and exclusion criteria. The inclusion criteria are age $\geq 18$; minimum of $4 \mathrm{BM}$ up to a maximum of $10 \mathrm{BM}$ on diagnostic MRI scan; maximum diameter of single gross tumor volume (GTV) $2.5 \mathrm{~cm}$; maximum cumulative GTV of $30 \mathrm{~cm}^{3}$; Karnofsky performance status $\geq 70$; any solid primary tumor, small cell lung carcinoma, germinoma and lymphoma are excluded; and patients' ability to provide written informed consent. The exclusion criteria are a contraindication for MRI, prior treatment for BM (i.e. surgery, SRS or WBRT), concurrent use of systemic therapy (systemic therapies should be stopped at least 1 week prior until 1 week after the radiotherapy), maximum cumulative GTV of more than $30 \mathrm{~cm}^{3}$ on planning-MRI, more than $10 \mathrm{BM}$ on planning-MRI, leptomeningeal disease and brainstem metastasis with a PTV of more than $20 \mathrm{~cm}^{3}$. If a patient is not eligible based on the inclusion or exclusion criteria of this study based on the planning-MRI results prior to randomization (e.g. $>10$ BM, GTV diameter $>2.5 \mathrm{~cm}$, cumulative GTV>30 $\mathrm{cm}^{3}$ ), these non-eligible patients will be replaced by a new patient. These patients are not included in the statistical analysis of the trial.

\section{Study procedures WBRT}

On a gadolinium contrast-enhanced (single - triple dose Gd is allowed) MRI (1.0T-3T) with a maximal slice thickness of $1.5 \mathrm{~mm}$, the definitive number of BM and the definitive maximum lesion diameter in any direction of the largest BM are determined. Patients randomized for WBRT will be treated with five fractions of 4 Gy up to a total dose of $20 \mathrm{~Gy}$ delivered in five consecutive working days. Dose prescription is according to ICRU 50 criteria.[4] The brain is contoured as a clinical target volume (CTV) until the foramen magnum. The CTV is equal to the PTV. To determine the size of the GTVs of the metastases, all BMs and lenses are contoured. Patients are positioned with a mask. The use of a planning CT is mandatory with slice thickness of $\leq 3 \mathrm{~mm}$. The use of a contrast medium is not obliged. The planning-MRI is co-registered for contouring of the BM. The daily prescription dose will be 4 Gy prescribed at the ICRU reference point, and the 95\% isodose must encompass $99 \%$ of the planning target volume (PTV); the maximum dose to the PTV should not exceed $107 \%$ of the prescribed dose. Generally, two opposed lateral fields are used with shielding of lenses and the pharyngeal space. All techniques that result in the dose requirements being met are allowed. 


\section{Study procedures of SRS}

Only single fraction treatments are allowed within this protocol. For any given patient, all brain metastases will be treated with the same dose, which will be determined by the PTV of the largest BM or brainstem location in the range of 15-24 Gy.(Table 1) The dose gradient outside the PTV will be as steep as possible to spare healthy brain tissue. Within the PTV, there will be considerable dose inhomogeneity, with a maximum allowed dose within the PTV of $140 \%$ of the prescribed dose. The GTV is defined by contouring the outer contrast-enhancing border of the BM on T1 gadolinium-weighted MRI images. BM are named GTVp1, GTVp2, GTVp3, from the cranial to the caudal side. Organs at risk (brainstem, optic nerves, chiasma, pituary gland, cochleae, and lenses) are contoured according to Scoccianti et al. [5]. The PTV is defined by a $0-2 \mathrm{~mm}$ isotropic expansion of the GTV, according to institutional standards for SRS. If a BM is within or adjacent to the brainstem, the PTV margin will be $0 \mathrm{~mm}$. If in an institution, a smaller GTV to PTV margin is used when lesions are treated using multiple isocentres, then this technique is to be considered to reduce the $V_{12 G y}$ of the largest $B M$ if it would otherwise be more than $10 \mathrm{~cm}^{3}$.

Patients will be immobilized in a supine position within a thermoplastic mask or stereotactic noninvasive frame, with or without bite block and/or other fixation, according to institutional standards for SRS. The accuracy of the stereotactic fixation system should be good enough to justify the CTV to PTV margin used. This means the intrafraction motion should at least be within the CTV-PTV margin used. If a margin of $0 \mathrm{~mm}$ is used, the maximum intrafraction motion should be $<0.5 \mathrm{~mm}$, with the SD being less than 0.25 $\mathrm{mm}$. A planning CT scan with $\leq 2 \mathrm{~mm}$ thick contiguous slices (preferable CT slice thickness $=1 \mathrm{~mm}$ ) will be fused to a contrast-enhanced stereotactic MRI scan. The interval between the planning-MRI and actual SRS treatment is a maximum of 3 weeks. Single or multiple isocentres are allowed for delivering SRS according to the preference of treatment center. Tissue density inhomogeneity correction will be used. Positional verification and correction prior to (and/or during) radiation should be executed according to the institutional protocol for stereotactic radiotherapy and should be in accordance with the CTV-PTV margin used. All techniques that result in the dose requirements being met are allowed. Participating institutes will have to define their radiation delivery treatment prior to the initiation of the study. Techniques that have a shorter treatment time duration are preferred as this is more comfortable for the patient and might prevent an increase in the intrafraction displacement over the treatment time. All vendors are allowed to deliver SRS, such as a linear accelerator, Gamma Knife and CyberKnife. 
Table 1 SRS dose prescription in trial. All BMs are dosed equally in the same patient. If the $V_{12}$ Gy exceeds 10 $\mathrm{cm}^{3}$ of the healthy brain tissue nearby the largest brain metastasis, it is allowed to lower the fraction dose to a single dose of $21,18,16$, or 15 Gy.

\begin{tabular}{lll}
\hline PTV of the largest brain metastasis & Doses in each PTV & BM in brainstem (GTV=PTV) \\
\hline$<1 \mathrm{~cm}^{3}$ & $1 \times 24 \mathrm{~Gy}$ & $1 \times 16 \mathrm{~Gy}$ \\
$1-10 \mathrm{~cm}^{3}$ & $1 \times 21 \mathrm{~Gy}$ & $1 \times 16 \mathrm{~Gy}$ \\
$10-20 \mathrm{~cm}^{3}$ & $1 \times 18 \mathrm{~Gy}$ & $1 \times 16 \mathrm{~Gy}$ \\
$20-65 \mathrm{~cm}^{3}$ & $1 \times 15 \mathrm{~Gy}$ & No SRS \\
\hline
\end{tabular}

\section{Number of patients and recruitment}

Questionnaires measuring QOL with the EQ5D EUROQOL questionnaire are collected from patients with multiple BM treated with WBRT or SRS at baseline and at 3 months after treatment. For this phase III trial, sample size calculation is based on the clinically relevant difference of 0.10 points of the EQ5D-5L index value (range $0-1$ ) at 3 months after treatment with regard to baseline, with a standard deviation of 0.25 points. For every patient this difference in EQ5D-5L QOL score is calculated (score at 3 months minus score at baseline). The average score of all patients in the SRS group is calculated and this average score is compared to the calculated average score of all patients in the WBRT group. This is accordingly the method described by Pickard.[6] Sample size calculation is performed for a comparison of means with two-sided alpha 0.05 and power of 0.80 . This leads to a sample size per group of 100 patients. To account for drop out, the sample size for this study will be increased by $15 \%$ to 230 patients (115 per group). After 86 patients treated, an interim analysis is performed to monitor the safety of the trial regarding the experimental SRS arm.

Patient accrual was started on 1st July, 2016. Up to 14th April, 2017, nine patients were randomized. With expected participation of 12 centers, it is estimated that patient's accrual can be completed within 2 years with an expected accrual of 10-15 patients each year per center.

For this phase III study, a comparison of the above described difference in EQ5D score between SRS and WBRT group will be performed using an independent samples Student's t-test with two-sided significance level alpha set at 0.05. A clinical significant difference in EQ5D is determined at 0.10 points in the index score.[4] For the total patient cohort, a multivariate analysis is performed to identify prognostic factors for a difference in EQ5D score at 3 months with regard to baseline. Differences in secondary endpoints that repeat in time are analyzed with Kaplan Meyer curves including log-rank test or ANOVA test. Time-to-event data (e.g. overall survival) will be compared using Kaplan-Meier curves and log-rank test. Means will be compared using independent samples Student's t-tests. Frequencies (e.g. WHO-PFS) will be compared using Chisquare test. 


\section{DISCUSSION}

A typical SRS treatment requires a high-resolution contrast-enhanced planning-MRI, frameless mask, a planning-CT, a treatment plan and quality assurance. Generally, all preparations will take a maximum of 2 weeks. Duration of SRS delivery depends on the number of isocentres, arcs and dose rate, but usually in the range of several minutes up to $45 \mathrm{~min}$. With WBRT, all other preparation steps are required, but treatment planning and quality assurance are less complex. WBRT treatment is delivered in five fractions compared to a single treatment fraction with SRS. Questionnaires will be assessed at baseline, 3 months after treatment and every 3 months thereafter until 1 year after treatment. Questionnaires can be assessed by telephone, or during scheduled outpatient clinic visits. Not all hospitals have the logistic capacity to perform neurocognitive tests and extensive QOL assessment; hence, neurocognitive function (Hopkins Verbal Learning Test) and more extensive QOL (EORTC QLQ-C30, EORTC BN20, and EORTC QLQ-FA13) will be facultative endpoints and will only be performed at baseline and at 3 months after radiotherapy at the outpatient clinic in centers willing to participate. Although these secondary endpoints are facultative, these endpoints will also provide valuable information, and participating centers are recommended to monitor them.

\section{LIST OF ABBREVIATIONS}

$\mathrm{BM}=$ brain metastases; $\mathrm{CT}=$ computed tomography; $\mathrm{CTCAE}=$ common criteria of adverse events; GTV=gross tumour volume; Gy=Gray; ICRU=International Commission on Radiation Units \& Measurements; MRI=magnetic resonance imaging; PTV=planning target volume; $\mathrm{QOL}=$ quality of life; $\mathrm{SRS}=$ stereotactic radiosurgery; $\mathrm{WBRT}=$ whole brain radiotherapy

\section{DECLARATIONS}

\section{Ethics approval and consent to participate}

This study was approved by the ethics committee of the following hospital: the Maastricht University medical center (MUmc+), Maastricht, the Netherlands: reference number protocol NL53852.068.15/METC153053. The responsible investigator will ensure that this study is conducted in agreement with the Declaration of Helsinki (Brazil, October 2013) and in accordance with the Medical Research Involving Human Subjects Act (WMO). The protocol has been written, and the study will be conducted according to the ICH Harmonized Tripartite Guideline for Good Clinical Practice (ref: http://www.ifpma.org/pdfifpma/e6.pdf). All patients will be informed about the aims of 
the study, the possible adverse events, the procedures and possible hazards to which they will be exposed. They will be informed about the strict confidentiality of their data, and that their medical records may be reviewed for trial purposes by authorized individuals other than their treating physician. Information will be given in both spoken and written form as given in the Patient Information text. The Patient Informed consent statement and the Patient Information text are given as an appendix to this protocol. It will be emphasized that the participation is completely voluntary, and the patient does not need to give any further explanation for not participating. The patient is allowed to refuse further participation in the protocol whenever he wants. This will not prejudice the patient's subsequent care. Documented informed consent must be obtained for all patients included in the study before they are registered in the study.

\section{Consent for publication}

All patients have provided written informed consent for participation in this trial, and publication of the results gathered in this trial. The publication does not contain recognizable individual patient data, but an analysis of the results of the whole study population $(n=230)$.

\section{Availability of data and material}

The study coordinator (JZ) has full access to the original data, the sequence of authors has been determined upfront, and all authors will read the final report before publication. The first author on papers with results of the study will be JZ (Jaap Doeke Zindler), second author AB (Anne Marie Bruynzeel), third author DE (Danielle Eekers), fourth author $\mathrm{CH}$ (Coen Hurkmans), fifth author Ans Swinnen and the last author will be PL (Philippe Lambin). The same policy will be applied to side results. Everyone who further contributed, such as investigators or participating centers, will also be considered as coauthors. The sequence co-authorship of participating investigators will be determined by the number of patients included in the study. Persons who contributed in a minor way to a study may be considered for the acknowledgments section. Results will be published unreservedly regardless of their nature in accordance with the CCMO statement on publication policy.

\section{Competing interests}

The department of radiotherapy of MAASTRO clinic has a research agreement with Varian Medical Systems, Palo Alto USA. Varian Medical Systems is not involved in the design of the study, and collection/storage/analysis of the data gathered in this study. 


\section{Funding}

According to the research agreement of MAASTRO clinic with Varian Medical Systems, this trial is mentioned and financially supported. Varian Medical Systems is not involved in the design of the study, and collection/storage/analysis of the data gathered in this study.

\section{Authors contributions}

JZ has written the study protocol in close cooperation with $A B$ and PL. CH, DE, and AS also commented on the content of the study protocol. All authors have read and approved this manuscript.

\section{Acknowledgements}

MAASTRO clinic: Rody Zuidema, Anita Botterweck, Kim Smits, and Andre Dekker for their support and collaboration in this trial. Ruud Houben for advice considering statistical analysis.

VUmc Amsterdam: Frank Lagerwaard for commenting on the study protocol.

All patients willing to participate, all referring physicians supporting this trial and coinvestigators of other hospitals who participate in this multicentre study.

\section{Author information}

JZ: radiation oncologist, MAASTRO clinic Maastricht, the Netherlands; AB: radiation oncologist, VU university medical centre, the Netherlands; DE: radiation oncologist, MAASTRO clinic Maastricht, the Netherlands; $\mathrm{CH}$ : clinical physicist radiation oncology, Catharina Hospital, Eindhoven, the Netherlands; AS: clinical physicist radiation oncology, MAASTRO clinic, Maastricht, the Netherlands; PL: radiation oncologist and research professor, MAASTRO clinic, Maastricht, the Netherlands 


\section{REFERENCES}

[1] Brown PD, Jaeckle K, Ballman KV, et al. Effect of Radiosurgery Alone vs Radiosurgery With Whole Brain Radiation Therapy on Cognitive Function in Patients With 1 to 3 Brain Metastases: A Randomized Clinical Trial. JAMA. 2016 Jul 26;316(4):401-9

[2] Mulvenna P, Nankivell M, Barton R, et al. Dexamethasone and supportive care with or without whole brain radiotherapy in treating patients with non-small cell lung cancer with brain metastases unsuitable for resection or stereotactic radiotherapy (QUARTZ): results from a phase 3, non-inferiority, randomised trial. Lancet. 2016 Oct 22;388(10055):2004-2014.

[3] Yamamoto $M$, Serizawa $T$, Shuto $T$, et al. Stereotactic radiosurgery for patients with multiple brain metastases (JLGK0901): a multi-institutional prospective observational study. Lancet Oncol. 2014 Apr;15(4):387-95

[4] Chavaudra J, Bridier A. Definition of volumes in external radiotherapy: ICRU reports 50 and 62]. Cancer Radiother. 2001 Oct;5(5):472-8.

[5] Scoccianti S, Detti B, Gadda D, et al. Organs at risk in the brain and their dose-constraints in adults and in children: a radiation oncologist's guide for delineation in everyday practice. Radiother Oncol. 2015;114(2):230-8.

[6] Pickard, A Simon, Maureen P Neary, and David Cella. "Estimation of Minimally Important Differences in EQ-5D Utility and VAS Scores in Cancer." Health and Quality of Life Outcomes 5 (2007): 70. PMC. Web. 23 Feb. 2015. 

Chapter

\section{Propensity-score matched pair comparison of whole brain with simultaneous in-field boost radiotherapy and stereotactic radiosurgery}

Radiother Oncol. 2013 Feb;106(2):206-9

Rodrigues G, Zindler J, Warner A, Bauman G, Senan S, Lagerwaard F. 


\section{ABSTRACT}

Purpose To compare lesional stereotactic radiosurgery to whole brain (WBRT) radiotherapy with simultaneous in-field boost for brain metastases in terms of overall survival.

Methods A retrospective review was performed on two institutional databases of 500 patients diagnosed with brain metastatic disease who received either stereotactic radiosurgery (SRS, $n=381$ ) or whole brain with simultaneous in-field boost radiotherapy (SIB, $n=119$ ), between 2002 and 2011. Propensity-score matching was utilized to obtain two groups with similar known prognostic factor characteristics. Kaplan-Meier and univariable/multivariable Cox modeling were conducted to assess the treatment impact on overall survival (OS).

Results Propensity-score matching created a matched cohort of 178 patients (89 SRS/SIB) with similar baseline characteristics. Multivariable analysis demonstrated that presence/absence of systemic metastases, patient age, tumor volume, and presence/absence of active primary were found to be more predictive of OS than treatment assignment $(p=0.38)$. SIB was associated with reduced intracranial failure likely due to the WBRT component of the treatment (HR 0.36, $p<0.001)$.

Conclusions Adjusting for other predictive factors, treatment with either SRS or SIB did not result in any statistically significant difference in OS; however, observed intracranial failure was different due to the use of WBRT in the SIB cohort. 


\section{INTRODUCTION}

The management of brain metastases has been the subject of multiple randomized controlled trials and knowledge translation documents [1] and [2]. Aggressive therapy with neurosurgical resection or stereotactic radiosurgery (SRS) is usually reserved for patients with good performance status, low burden oligometastatic disease, and controlled extracranial/primary disease. Important clinical endpoints to be optimized with treatment include: survival, neurological stabilization/improvement, prevention of neurologic death, lesion control, steroid dose reduction, symptom palliation, and quality-oflife.

Important unanswered questions remain in the field of brain metastases radiotherapy. One such question relates to the therapeutic ratio of whole brain radiotherapy (WBRT) when given in conjunction with single fraction or multiple fraction SRS or radiation therapy in terms of important clinical outcomes such as survival and lesional control. While the use of WBRT has been shown to increase intracranial control [3], [4] and [5], some published evidence suggests negative effects in terms of neurocognitive function and overall survival [6]. However, the measurement of neurocognitive function and associated quality-of-life changes can be challenging [7] due to changes in toxicity over time and inadequate late assessments [8].

Matching patients together by known prognostic factors can be an alternative method to explore differences in patient outcome between treatment groups, in the absence of randomized controlled clinical trial data, specifically, propensity-score matched pair analysis allows for a statistical model-based approach to create similar comparison groups for analysis and interpretation [9]. This approach has an advantage over traditional matching techniques due to minimization of the bias related to treatment selection/assignment [10]. We report on such a matched pair analysis comparing SIB (whole brain with simultaneous in-field boost radiotherapy) to SRS treatment (without WBRT). The impact of differences in local (single dose SRS vs. fractionated radiotherapy) and regional (SRS alone vs. WBRT within SIB approach) treatments in terms of important clinical outcomes such as overall survival (OS) and intracranial failure (from both local lesion failure and/or distant failure in the brain) is examined.

\section{METHODS AND MATERIALS}

\section{Database composition}

A retrospective review was performed on two institutional review board approved institutional databases of 500 patients diagnosed with brain metastatic disease who received either SRS ( $n=381)$ or SIB $(n=119)$ between 2002 and 2011 with outcome in- 
formation on OS and Response Evaluation Criteria in Solid Tumors (RECIST) intracranial failure. Patients were treated at one of two cancer centers: London Regional Cancer Program (LRCP, London, ON, $\mathrm{n}=69$ SIB patients) or at VU Medical center (VUmc, Amsterdam, The Netherlands, $n=381$ SRS patients plus $n=50$ SIB patients). Institutional ethics approval was obtained for this joint database analysis.

\section{SRS cohort}

The VUmc SRS database contains baseline characteristics, treatment details and followup data for patients with 1-3 BM diagnosed with high resolution (2 $\mathrm{mm}$ slice thickness, triple dose gadolinium) MRI scans who were eligible for linac-based SRS as a single modality. SRS was delivered by 5 dynamic conformal arcs on a Novalis (2002-2008, $n=50$ for matched cases) or Novalis TX (2008-2012, $n=39$ for matched cases) linear accelerator using a relocatable Gill-Thomas-Cosman frame (2002-2008) or a frameless mask system (2008-2012) [BrainLAB, Feldkirchen, Germany]. The SRS target volumes consisted of the gross tumor volume contoured on the planning MRI with a $1 \mathrm{~mm}$ margin to correct for potential setup-inaccuracies for both SRS systems. SRS was prescribed with the $80 \%$ isosurface covering the GTV and a 'risk-adapted' dose based on lesion volume: $\leq 7.5 \mathrm{~cm}^{3} 21 \mathrm{~Gy}, 7.5-25 \mathrm{~cm}^{3}$ or lesions near brainstem $18 \mathrm{~Gy}$ with other all other lesions $15 \mathrm{~Gy}$ in 1 fraction or $24 \mathrm{~Gy}$ in 3 fractions. Follow-up was standardized as per institutional guidelines and consisted of 3-monthly clinic visits with contrast-enhanced MRI investigation during the first year, followed by 6-monthly MRI scans during the second year, and yearly scans thereafter.

\section{SIB cohort}

Technical details of the SIB techniques at both the VUmc and LRCP have been published [11], [12] and [13] and are summarized as follows. Patient selection criteria for treatment in the VUmc series included: not rapidly progressing extracranial disease that in the opinion of the investigator would, WHO score 0-3, and 1-6 lesions with cumulative volume $<30 \mathrm{~cm}^{3}$. Patients were positioned supine in a frameless mask system [Brainlab AG, Feldkirchen, Germany]. Planning CT scans (GE Healthcare) without intravenous contrast were obtained with a $2.5 \mathrm{~mm}$ slice thickness. Contrast-enhanced T1-sequences (slice thickness $2 \mathrm{~mm}$, with a 3D-distortion correction protocol) of a co-registered recent ( $<3$ weeks) diagnostic MRI scan were used for GTV definition. The whole brain radiotherapy planning target volume (WBRT_PTV) was derived from autosegmentation of the brain on the CT scan, with the addition of a $2 \mathrm{~mm}$ symmetric margin. The SIB PTV was derived by contouring the outer contrast-enhancing border of the brain metastases and adding a $2 \mathrm{~mm}$ margin. Treatment planning, calculation and quality assurance were performed using two complementary volumetric modulated arcs [RapidArc with Eclipse v8.6.3, Varian medical systems] calculated using the AAA calculation model and con- 
firmed using film dosimetry as previously described [12]. The SIB plan delivered a total dose of 20 Gy to the WBRT volume with a total lesional dose of 40 Gy all in 5 fractions. Treatment was delivered on a Novalis TX linear accelerator, with patient setup using the $6 \mathrm{D}$ robotic couch and the Brainlab ExacTrac system [BrainLAB, Feldkirchen, Germany]. Routine patient follow-up was similar to that after SRS, described above.

LRCP patient selection generally included WHO performance status 0-3, systemic disease absent/controlled and 0-3 metastases none larger than $3 \mathrm{~cm}$. All patients had a custom thermoplastic shell created prior to planning CT (S-frame, CIVCO, Iowa, USA). A planning CT (Phillips Healthcare) was obtained with a $3 \mathrm{~mm}$ slice thickness and fused with contrast-enhanced MRI (CT simulation with contrast was utilized if MRI was unavailable). The individual contrast enhancing lesions were contoured as the SIB targets without margin. The whole cranial contents with a $3 \mathrm{~mm}$ 3D margin were contoured as the target for the whole brain treatment. A variety of total SIB doses ranging from 3560 Gy were utilized at the LRCP; however, in all cases the whole brain dose was $30 \mathrm{~Gy}$ and all treatments were delivered over 10 fractions. Dose-volume histogram optimization, planning parameters, evaluation criteria, and image-guidance procedures were as published previously. All patients were clinically or radiologically (CT or MRI brain) evaluated in a similar manner to the VUmc (every 3 months).

\section{Statistical analysis}

All patients were eligible for the matching procedure which utilized propensity scores generated from a multivariable logistic regression model predictive of treatment group (SIB vs. SRS), and adjusting for covariates including: age, year of treatment, primary tumor type, presence of systemic metastases, WHO performance status, initial diagnosis to brain metastases time interval, total volume of brain metastases, and status of primary tumor. To assess the degree of similarity between treatment groups and the overall performance of the matching procedure, univariable analysis was performed on all covariates included in matching procedure by treatment group (using Chisquare/Fisher's exact tests and two-sample t-tests for categorical and continuous variables, respectively). It was determined that using a ratio of 1 SIB: 1 SRS patient and a calliper distance of 0.025 yielded sufficient power and similarity between treatment groups to proceed with matching (final matched cohort of 89 SIB patients with 89 SRS patients).

The primary endpoint for this study was OS (defined as date of initiation of radiotherapy to date of last follow-up or death). The secondary endpoint for this matched pair analysis was radiological confirmation of intracranial failure which is composed of two separate types of failure: local lesional failure and distant failure in the brain not involving the treated lesions. Estimates of overall survival were obtained using Kaplan-Meier method on the final matched cohort of 178 patients (89 SRS and 89 SIB) stratified by 
treatment group (SRS vs. SIB). To identify significant predictors of OS, backward elimination multivariable cox regression analysis (using $p<0.15$ Wald Chi-square test for model halting) was performed on the matched cohort $(n=178)$ after initial univariable modeling ( $p>0.30$ for removal for further consideration). The remaining set of covariates was included in a multivariable cox regression, which included treatment group (SRS vs. SIB) as a covariate.

\section{RESULTS}

Descriptive statistics relating to patient, tumor, and treatment parameters for all patients ( $n=500, n=119$ SIB and $n=381$ SRS) as well as propensity-score matched patients ( $n=178, n=89$ SIB and $n=89$ SRS) are summarized in Supplementary Table e1. Review of this summary table demonstrates that the propensity-score matching achieved the goal of balancing the SRS and SIB patient populations with regard to known prognostic factors and published prognostic indices. Only one variable remained statistically different between the SRS and SIB groups; which was year of treatment. This is a reflection of the longer use of SRS over newer SIB techniques. The KaplanMeier curve comparing SRS (median survival $=4.50$ months) vs. SIB (median survival = 5.62 months) matched patients is depicted in Fig. $1(p=0.32)$. Median survival for unmatched patients was higher at 7.73 months for SRS and 5.82 for SIB ( $p=0.06$, KaplanMeier plots not shown). Kaplan-Meier plots of radiologically confirmed intracranial failure demonstrated less intracranial failure with SIB treatment (16/89 (8 lesional failure +4 distant brain failure +4 both lesion and distant brain failures) cases for SIB vs. 35/89 (13 lesional failure +15 distant brain failure +7 both lesion and distant brain failures) cases for SRS, HR 0.36, log rank $p<0.001$ ). 


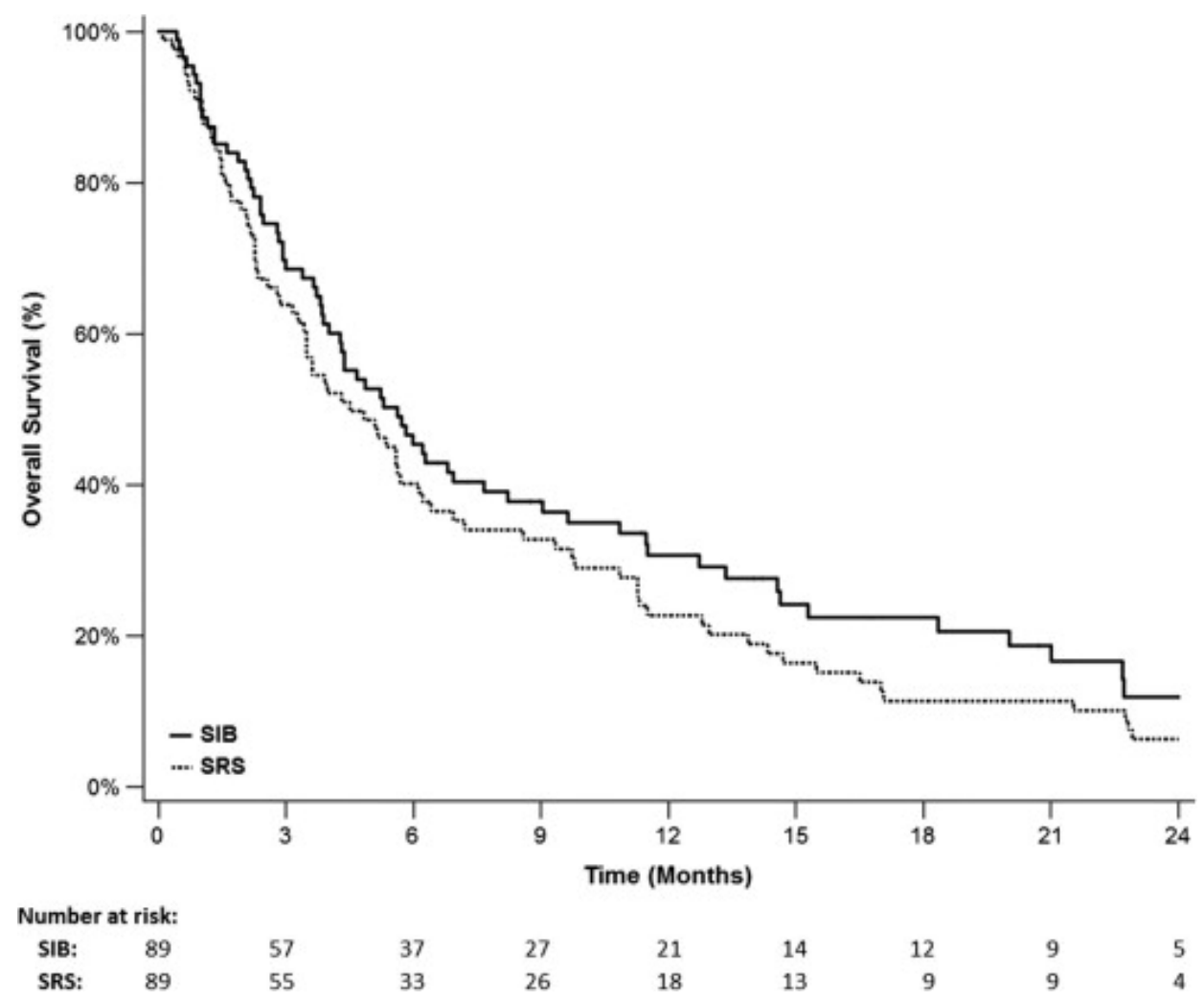

Figure 1 Overall survival with Kaplan Meyer analysis for matched patients treated with SRS and SIB techniques. Legend: SIB=simultaneous integrated boost, SRS=stereotactic radiosurgery

Univariable Cox modeling for matched $(n=178)$ and all patients $(n=500)$ is summarized in Table 1. Treatment assignment was not a statistically significant predictor of OS. Results of the backward elimination are shown in Table 2. Given that the primary covariate of interest, treatment group was not retained in the initial model (Model 1: Matched Cohort without SRS/SIB), an additional model was constructed including it as a covariate (Model 2: Matched Cohort with SRS/SIB). To assess the relative strength of covariates on the original cohort and the impact of propensity-score matching on survival outcomes; both models were constructed based on the complete cohort of patients (Models 3 and 4, Supplemental Table e2). 
Table 1 Summary of p-values reported from univariable cox regressions for overall survival (dependent variable), reported from analyses based on matched patients $(n=178)$ and all patients prior to matching $(n=500)$

\begin{tabular}{|l|l|l}
\hline Characteristic & $\begin{array}{l}\text { Matched patients } \\
n=178\end{array}$ & $\begin{array}{l}\text { All patients } \\
n=500\end{array}$ \\
& $\begin{array}{l}p \text {-Value } \\
p \text {-Value }\end{array}$ \\
\hline Treatment (SIB vs. SRS) & 0.322 & 0.065 \\
\hline Age & 0.037 & $<0.001$ \\
\hline Sex & 0.669 & 0.019 \\
\hline 'Primary tumor & 0.628 & 0.003 \\
\hline 'Systemic metastases & 0.022 & $<0.001$ \\
\hline 'WHO performance status & $<0.001^{* *}$ & $<0.001$ \\
\hline 'Initial to brain metastases interval & 0.715 & 0.048 \\
\hline 'Total Volume of Brain Metastases & 0.212 & 0.016 \\
\hline Number of brain metastases & 0.275 & $<0.001$ \\
\hline Active primary tumor & 0.497 & 0.008 \\
\hline RPA & 0.061 & $<0.001$ \\
\hline BSBM & 0.169 & $<0.001$ \\
\hline SIR group & 0.525 & $<0.001$ \\
\hline GPA group & 0.179 & $<0.001$ \\
\hline GGS group & 0.002 & $<0.001$ \\
\hline DSGPA group & 0.004 & $<0.001$ \\
\hline RADES1 group & 0.087 & $<0.001$ \\
\hline RADES2 group & 0.134 & $<0.001$ \\
\hline
\end{tabular}

$\mathrm{WHO}=$ World Health organization, RPA = recursive partitioning analysis, BSBM = basic score of brain metastases, SIR = score index for radiosurgery, GPA = graded prognostic index, GGS = golden score, DSGPA = disease-specific GPA, RADES1 = Rades et al. first classification system (2008),

RADES2 = Rades et al. second classification system (2011).

* Used in propensity-score computation procedures. Matched: bold if $p<0.30$. All patients: bold if $p<0.01$.

\section{DISCUSSION}

This analysis has demonstrated that treatment assignment (SRS without WBRT vS. WBRT with SIB) did not significantly predict for OS outcome. Stated differently; adjusting for other known prognostic factors, OS of patients treated with SIB (with WBRT) and 
SRS (no WBRT) were similar to each other. Prognostic factors such as presence/absence of systemic metastases, patient age, tumor volume, and presence/absence of active primary were found to be more predictive than treatment assignment. Many of these factors have been demonstrated to be important for patient outcome in various prognostic indices [14]. This finding of treatment prognostic effect being less than other baseline prognostic factors was subjected to a sensitivity analysis for both the matched and unmatched patient populations and was maintained in both populations.

Table 2 Multivariable cox regression models examining relationships between individual predictors of overall survival based on propensity-score matched patients $(n=178)$. Model 1: Main model adjusting for all covariates. Model 2 Adjusting for all covariates forcing inclusion of treatment. Legend: SRS=stereotactic radiosurgery; SIB simultaneous integrated boost; $\mathrm{Cl}=$ confidence interval. Bold if $\mathrm{p}<0.1$.

\begin{tabular}{|c|c|c|c|c|}
\hline Univariable & $p$-Value & Model 1 & $p$-Value & Model 2 \\
\hline $\begin{array}{l}\text { Hazard ratio } \\
(95 \% \mathrm{Cl})\end{array}$ & & $\begin{array}{l}\text { Hazard ratio } \\
(95 \% \mathrm{Cl})\end{array}$ & & $\begin{array}{l}\text { Hazard ratio } \\
(95 \% \mathrm{Cl})\end{array}$ \\
\hline
\end{tabular}

Dependent variable:

Overall survival

Independent variables:

\begin{tabular}{|c|c|c|c|c|c|c|}
\hline SRS (ref. SIB) & $\begin{array}{l}1.18 \\
(0.85,1.61)\end{array}$ & 0.322 & - & - & $\begin{array}{l}1.16 \\
(0.84,1.59)\end{array}$ & 0.378 \\
\hline $\begin{array}{l}\text { Systemic metastases } \\
\text { (ref: No) }\end{array}$ & $\begin{array}{l}1.53 \\
(1.06,2.19)\end{array}$ & 0.022 & $\begin{array}{l}1.94 \\
(1.30,2.90)\end{array}$ & 0.001 & $\begin{array}{l}1.92 \\
(1.29,2.86)\end{array}$ & 0.001 \\
\hline $\begin{array}{l}\text { Age (per } 10 \text { unit } \\
\text { increase) }\end{array}$ & $\begin{array}{l}1.16 \\
(1.01,1.34)\end{array}$ & 0.037 & $\begin{array}{l}1.22 \\
(1.05,1.40)\end{array}$ & 0.008 & $\begin{array}{l}1.22 \\
(1.05,1.41)\end{array}$ & 0.008 \\
\hline $\begin{array}{l}\text { Tumor volume (per } \\
10 \text { unit increase) }\end{array}$ & $\begin{array}{l}1.06 \\
(0.97,1.17)\end{array}$ & 0.212 & $\begin{array}{l}1.12 \\
(1.01,1.24)\end{array}$ & 0.036 & $\begin{array}{l}1.12 \\
(1.00,1.25)\end{array}$ & 0.042 \\
\hline $\begin{array}{l}\text { Active primary (ref: } \\
\text { No) }\end{array}$ & $\begin{array}{l}0.90 \\
(0.65,1.23)\end{array}$ & 0.497 & $\begin{array}{l}0.74 \\
(0.52,1.04)\end{array}$ & 0.084 & $\begin{array}{l}0.75 \\
(0.53,1.06)\end{array}$ & 0.106 \\
\hline
\end{tabular}

Investigations and clinical trials related to brain radiotherapy have questioned the utility of the WBRT component of the combined WBRT + SRS treatment. These studies have generally demonstrated that patients who do not receive the WBRT component of treatment may have better neurocognitive function with similar survival but an increased risk of regional brain relapse from $40 \%$ to $60 \%$ [2], [3] and [5]. Our matched pair analysis also detected a $64 \%$ absolute decrease in radiological intracranial failure with the inclusion of WBRT, which is consistent with these published prospective studies. Despite the difference in intracranial control, radiation oncologists are increasingly excluding the WBRT component of SRS treatment and considering salvage SRS treatment for clinically significant intracranial recurrences in order to optimize neurocognitive functioning given the equivalent OS characteristics observed in various reports including the present one. 
Prospective clinical trials assessing fractionated radiotherapy (either alone or given with concurrent WBRT with SIB) are currently limited to one randomized controlled trial assessing hyperfractionation [15] and one phase I SIB dose-finding study [13]. Most other literature reports consist of single institution retrospective reports with no matched comparison group(s) [16]. Compared to other fractionated brain metastases reports, the current work is novel as a matching procedure was conducted to control for known prognostic factors. This work suggests that the fractionated approach (given by WBRT plus SIB) may provide equivalent OS and intracranial/intralesional control results when compared to single dose SRS without WBRT.

The most significant limitation of this work is that it is based on retrospective data and that despite patient matching important differences between treatments may exist that can be detected in an adequately powered randomized controlled trial. For instance, the lack of toxicity data for direct comparison between radiotherapy approaches is another limitation of this report. Additionally, this study does not define potential good prognosis subpopulations of patients that may benefit from single fraction SRS techniques. Ideally, future phase III clinical trials comparing fractionated stereotactic radiotherapy techniques (with or without WBRT) against standard of care approaches (SRS with or without WBRT, neurosurgery plus WBRT, or WBRT alone) need to be conducted in order to draw more robust conclusions to guide patient care. Prior to such definitive trials, a new set of prospective phase I and II trials assessing fractionated stereotactic radiation treatment are currently underway in order to define optimal treatment strategies that balance treatment outcome, intracranial control, and neurocognitive side effects [16]. Future research into the neurocognitive impact(s) of delivering an SIB approach with hippocampal sparing should be also investigated. 


\section{REFERENCES}

[1] Tsao MN, Rades D, Wirth A, et al. Radiotherapeutic and surgical management for newly diagnosed brain metastasis(es): an American Society for Radiation Oncology evidence-based guideline. Pract Radiat Oncol 2012;2:210-25.

[2] Scoccianti S, Ricardi U. Treatment of brain metastases: review of phase III randomized controlled trials. Radiother Oncol 2012;102:168-79.

[3] Kocher M, Soffietti R, Abacioglu U, et al. Adjuvant whole-brain radiotherapy versus observation after radiosurgery or surgical resection of one to three cerebral metastases: results of the EORTC 2295226001 study. J Clin Oncol 2011;29:134-41.

[4] Aoyama H, Shirato H, Tago M, et al. Stereotactic radiosurgery plus whole-brain radiation therapy vs stereotactic radiosurgery alone for treatment of brain metastases: a randomized controlled trial. JAMA 2006;295:2483-91.

[5] Aoyama H, Tago M, Kato N, et al. Neurocognitive function of patients with brain metastasis who received either whole brain radiotherapy plus stereotactic radiosurgery or radiosurgery alone. Int J Radiat Oncol Biol Phys 2007;68:1388-95.

[6] Chang EL, Wefel JS, Hess KR, et al. Neurocognition in patients with brain metastases treated with radiosurgery or radiosurgery plus whole-brain irradiation: a randomised controlled trial. Lancet Oncol 2009;10:1037-44.

[7] Baschnagel A, Wolters PL, Camphausen K. Neuropsychological testing and biomarkers in the management of brain metastases. Radiat Oncol 2008;17:26.

[8] Tallet AV, Azria D, Barlesi F, Spano JP, Carpentier AF, Gonçalves A, et al. Neurocognitive function impairment after whole brain radiotherapy for brain metastases: actual assessment. Radiat Oncol 2012;28:77.

[9] Rosenbaum PR, Rubin DB. The central role of the propensity score in observational studies for causal effects. Biometrika 1983;70:41-55.

[10] Austin PC. A critical appraisal of propensity-score matching in the medical literature between 1996 and 2003. Stat Med 2008;27:2037-49.

[11] Rodrigues G, Eppinga W, Lagerwaard F, et al. A pooled analysis of arc-based image-guided simultaneous integrated boost radiation therapy for oligometastatic brain metastases. Radiother Oncol 2012;102:180-6.

[12] Lagerwaard FJ, van der Hoorn EA, Verbakel WF, Haasbeek CJ, Slotman BJ, Senan S. Whole-brain radiotherapy with simultaneous integrated boost to multiple brain metastases using volumetric modulated arc therapy. Int J Radiat Oncol Biol Phys 2009;75:253-9.

[13] Rodrigues G, Yartsev S, Yaremko B, et al. Phase I trial of simultaneous in-field boost with helical tomotherapy for patients with one to three brain metastases. Int J Radiat Oncol Biol Phys 2011;80:1128-33.

[14] Rodrigues G, Bauman G, Palma D, et al. Systematic review of brain metastases prognostic indices. Pract Radiat Oncol 2012. http://dx.doi.org/10.1016/ j.prro.2012.04.001.

[15] Epstein BE, Scott CB, Sause WT, et al. Improved survival duration in patients with unresected solitary brain metastasis using accelerated hyperfractionated radiation therapy at total doses of 54.4 gray and greater. Results of Radiation Therapy Oncology Group 85-28. Cancer 1993;71:1362-7.

[16] Rodrigues G, Warner A, Bauman G, Senan S, Lagerwaard F. Systematic review of fractionated brain metastases radiotherapy. J Radiat Oncol 2012. http://dx.doi.org/10.1007/s13566-012-0035-x. 

Chapter

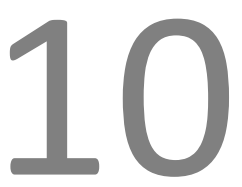

Increasing the Therapeutic Ratio of Stereotactic Ablative Radiotherapy by Individualized Isotoxic Dose Prescription

J Natl Cancer Inst. 2015 Oct 16;108(2)

Zindler JD, Thomas CR Jr, Hahn SM, Hoffmann AL, Troost EG, Lambin P 


\section{ABSTRACT}

To obtain a favorable tradeoff between treatment benefits and morbidity ("therapeutic ratio"), radiotherapy (RT) dose is prescribed according to the tumor volume, with the goal of controlling the disease while respecting normal tissue tolerance levels. We propose a new paradigm for tumor dose prescription in stereotactic ablative radiotherapy (SABR) based on organ-at-risk (OAR) tolerance levels called isotoxic dose prescription (IDP), which is derived from experiences and limitations of conventionally fractionated radiotherapy. With IDP, the radiation dose is prescribed based on the predefined level of normal tissue complication probability of a nearby dose-limiting OAR at a prespecified dose-volume constraint. Simultaneously, the prescribed total tumor dose (TTD) is maximized to the technically highest achievable level in order to increase the local tumor control probability (TCP). IDP is especially relevant for tumors located at eloquent locations or for large tumors in which severe toxicity has been described. IDP will result in a lower RT dose or a treatment scheduled with more fractions if the OAR tolerance level is exceeded, and potential dose escalation occurs when the OAR tolerance level allows it and when it is expected to be beneficial (if TCP $<90 \%$ ). For patients with small tumors at noneloquent sites, the current SABR dose prescription already results in high rates of local control at low toxicity rates. In this review, the concept of IDP is described in the context of SABR. 


\section{INTRODUCTION}

Stereotactic ablative radiotherapy (SABR), also referred to as stereotactic radiotherapy (SRT), stereotactic body radiotherapy (SBRT), or radiosurgery (RS), is a form of radiotherapy (RT) in which a high dose per fraction is delivered in a limited number of fractions with the aid of dedicated imaging and patient immobilization devices to minimize the treatment set-up margins of the irradiated tumor. With SABR, there is a steep-dose gradient outside the target volume to minimize the dose to organs at risk (OAR) and hence reduce the normal tissue complication probability (NTCP). SABR is increasingly being used in patients with metastasized cancer.

To obtain a favorable tradeoff between treatment benefit and morbidity ("therapeutic ratio"), the radiation dose is typically prescribed according to the target volume, with the goal of controlling the disease while respecting normal tissue tolerance levels. The therapeutic ratio is explained in Figure 1.[1] In resemblance to conventionally fractionated radiotherapy, we propose a paradigm shift for dose prescription in SABR from target-based to OAR-dependent tolerance levels called isotoxic dose prescription (IDP). $[2,3]$ With IDP, radiation dose is prescribed based on the predefined level of NTCP of a nearby dose-limiting OAR at a prespecified dose-volume constraint.[4-6] Simultaneously, the prescribed total tumor dose (TTD) is maximized to the technically highest achievable level in order to increase the local tumor control probability (TCP). The concept of IDP is shown in Figure 2 . IDP is especially relevant for tumors located at eloquent locations or for large tumors in which severe toxicity has been described. IDP will result in more fractions to achieve an ablative dose for SABR or to reduce the prescribed dose if the OAR tolerance level is exceeded. IDP will facilitate dose escalation when tolerance dose to critical OAR allows it and when it is expected to be beneficial (if TCP $<90 \%$ ). For patients with small tumors at noneloquent sites, the current SABR dose prescription already results in high rates of local control at low toxicity rates, and then IDP is less relevant. In this review, the concept of IDP is described in the context of SABR. 


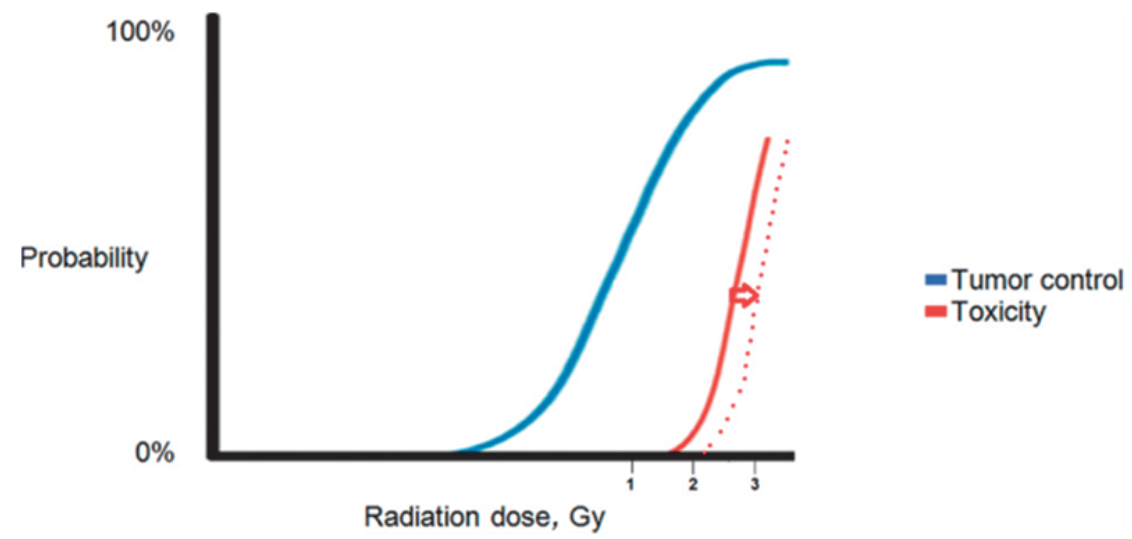

Figure 1 Therapeutic ratio in radiotherapy.

Legend: The therapeutic ratio denotes the relationship between the probability of tumor control and the likelihood of normal tissue damage. An improved therapeutic ratio represents a more favorable tradeoff between tumor control and toxicity.[53] The numbers 1, 2, and 3 represent potential stereotactic ablative body radiotherapy $(S A B R)$ dose prescriptions. With the dose prescribed in example 1, there is a relatively low TCP of $+/-40 \%$ with a normal tissue complication probability (NTCP) of $0 \%$. At the dose prescribed in example 2 , the TCP is $+/-80 \%$ with a low NTCP of $+/-5 \%$. The prescribed dose in example 3 results in a TCP of $+/-95 \%$, but at the cost of a NTCP 50\%, which is often regarded as being an unacceptable risk for NTCP. There are two options for lowering the NTCP: The SABR dose is lowered to example 2, or the SABR dose is delivered in more fractions in which the NTCP curve moves to the right (red dotted line), which results in a larger therapeutic ratio.

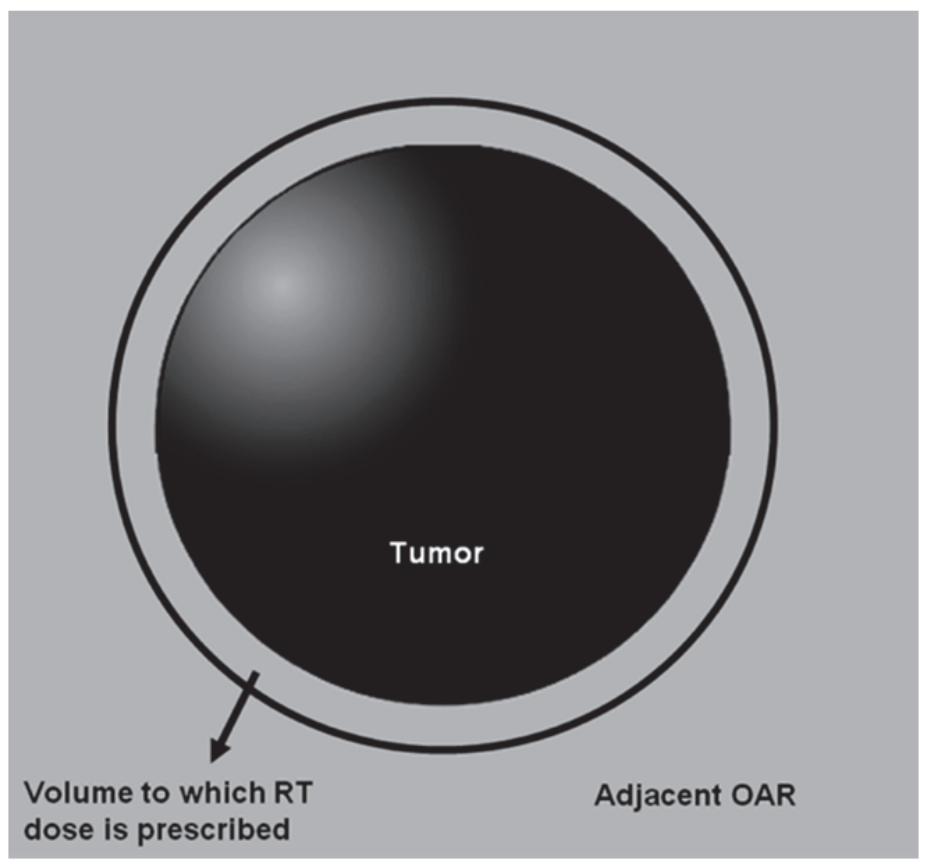

Figure 2 Concept of isotoxic dose prescription. 
Legend: Concept of isotoxic dose prescription (IDP): The radiotherapy dose is prescribed in relation to a volume of a dose-limiting adjacent organ at risk (OAR) based on a predefined level of acceptable normal tissue complication probability (NTCP). The total tumor dose (TTD) is escalated to the technically highest achievable level. An example of IDP for stereotactic ablative body radiotherapy of a brain metastasis is that a maximum volume of $10 \mathrm{~cm} 3$ of adjacent brain tissue may receive at least $12 \mathrm{~Gy}$ in a single fraction, which corresponds to an NTCP of $10 \%$ for symptomatic radionecrosis independent of tumor volume.[6] The tumor dose can be as high as technically achievable but should at least be $15 \mathrm{~Gy}$ in a single fraction. Conventional dose prescription in radiotherapy is based on tumor volume, not on the OAR tolerance. An example of a conventional dose prescription is a fixed single-fraction dose of 15 Gy prescribed on the target volume for every individual patient. However, uniformity in TTD prescription does not guarantee uniformity in NTCP. Because of the difference in tumor volume amongst patients, for some the OAR dose-volume constraint will not be met, whereas for others it is exceeded unless the prescribed tumor dose is lowered. With IDP, it is possible to individually tailor the dose prescription to a predefined level of acceptable toxicity (also see Figure 1 ). OAR = organ at risk; $\mathrm{RT}=$ radiotherapy.

\section{CURRENT STATUS OF SABR}

Dose prescription with SABR is far beyond the 2 Gy dose level of conventional fractionation, ranging from 7.5 to $100 \mathrm{~Gy}$ in one to eight fractions. Typical hypofractionation schedules comprise three to five fractions ranging from 10 to $20 \mathrm{~Gy}$ for early-stage nonsmall cell lung cancer (NSCLC), a single fraction of 24 Gy for a small brain metastasis, a single fraction of $12 \mathrm{~Gy}$ for vestibular schwannoma, and a single fraction of $70 \mathrm{~Gy}$ for trigeminal neuralgia.[7] The difference in SABR fractionation schedules is explained by the difference in disease entities (eg, a benign or malignant, type of tumor) while also taking into account life expectancy; high local control rates of approximately $90 \%$ are already achieved in vestibular schwannoma with a relatively low single-fraction dose, whereas for early-stage NSCLC, much higher doses are mandatory. In some countries (eg, the United States and the Netherlands), reimbursement may be, in part, dependent on the number of fractions or the dose per fraction, and this may influence the choice of fraction schedules and thereby the therapeutic ratio. There is evidence that the $2 \mathrm{~Gy}$ equi-effective dose (ie, the biologically equivalent total dose delivered using a fraction size of 2 Gy) in the SABR of early-stage NSCLC should be above 100 Gy to achieve local control rates of above 90\%.[8] In patients with oligometastatic cancer, lower SABR doses are often used, which results in relatively low local TCP. In a large retrospective study on patients treated with SABR for oligometastases, several fractionation schedules were used depending on the location of the metastasis and its proximity to an OAR, resulting in the vast majority of patients being treated with a 2 Gy equi-effective dose of less than 100 Gy.[9] Not surprisingly, local control two years after SABR was only 33\% and was statistically significantly $(P=.02)$ better for lesions treated with a 2 Gy equieffective dose greater than 75 Gy compared with a dose of less than 75 Gy. Life expectancy also plays a role. If the tumor is near an organ that is at risk for radiation toxicity (eg, spinal cord, brain, bowel) or the tumor volume is unfavorably large, fractionation schedules are often protracted to a relatively large number with an accordingly low 
dose per fraction in order to decrease the risk of late toxicity. An example of such a riskadapted fractionation schedule in early-stage NSCLC is eight fractions of 7.5 Gy for centrally located tumors instead of three fractions of 18 to $20 \mathrm{~Gy}$ for peripherally located ones. In general, the fractionation sensitivity (characterized by the reciprocal $\alpha / \beta$-value) of a relevant biological endpoint of late-responding normal tissue is lower than that for tumors. If the $\alpha / \beta$-value of the tumor is higher than that of the late-responding normal tissue, then a reduction of dose per fraction improves the therapeutic ratio, provided the overall treatment time is not extended.[10] Although the concept of SABR has been around for more than half a century, its clinical use has strongly expanded over the last decade, mainly because of high local control rates at acceptably low proven toxicity rates.[11]

Furthermore, the concept of the "oligometastatic disease state" has widened the indication for SABR to patients with stage IV solid tumors that were previously not eligible for (stereotactic) radiotherapy except for palliative purposes.[12] The aim of SABR in patients with a limited number of metastases (oligometastases typically comprise up to five lesions in a maximum of three visceral organ sites) is the prolongation of progression-free survival, postponing systemic treatment, and the long-term maintenance of quality of life.[13] For patients with one to three brain metastases, SABR is currently a standard treatment.[14,15] In stage I lung cancer treated with SABR, local control rates are comparable with surgery while simultaneously avoiding the morbidity and mortality of invasive approaches.[16,17] Randomized clinical trials are currently being designed to directly compare the outcome of SABR to surgery in operable patients, although patient accrual may be problematic because of the lack of equipoise from different specialties.[18,19] Other applications of SABR are the treatment of metastases or primary tumors in the liver, vertebra, adrenal gland, kidney, prostate, or lymph nodes.[13] There are several studies suggesting that the hypofractionated SABR of metastases may induce a so-called "abscopal" effect, ie, when highly immunogenic tumor antigens resulting from local SABR activate the immune system causing shrinkage of other metastases at nonirradiated sites.[20,21] This phenomenon has been described in primary tumor types such as melanoma, lymphoma, and renal cell carcinoma. It is hypothesized that cytotoxic T-cells and natural killer cells play a crucial role in the underlying biological mechanisms.[22,23] The widespread use of SABR at intra- and extracranial tumor sites has become possible because of several technical advances, making SABR a safe and patient-friendly technique.[24-27] Randomized studies are needed to identify which oligometastatic patients really benefit from ablative doses of SABR.[12]

\section{Toxicity of SABR}

Local control rates of SABR on small tumors at noneloquent locations are high ( $>90 \%)$ when applied according to current state-of-the-art procedures.[28] However, severe 
complications have been described in other situations because nearby OARs receive doses that can lead to organ dysfunction. Examples of severe toxicities are the following:

- SABR in early-stage NSCLC: risk of radiation pneumonitis in large-volume lung tumors (eg, planning target volume $>80 \mathrm{~cm} 3$ ) if the V 5Gy (the volume that receives at least $5 \mathrm{~Gy}$ ) of the contralateral lung is $\geq 26 \%$; [29]

- SABR in centrally located lung tumors: bronchial stenosis and/or necrosis;[30]

- SABR in brain metastases: symptomatic brain necrosis if more than $10 \mathrm{~cm} 3$ of the uninvolved brain tissue is irradiated with a single dose of at least $12 \mathrm{~Gy}$; [6]

- SABR in abdominopelvic tumors: bowel obstruction, perforation, and bleeding;[31]

- $\quad$ SABR in spinal metastases: myelopathy and vertebral fracture;[32,33]

- SABR in close to mediastinal structures: esophageal fistula.[34]

To minimize the risk of the severe toxicity of SABR, clinical researchers have developed dose-volume constraints for OARs.[35,36] However, most of these constraints remain unvalidated and only serve as a starting point of sorts in order to develop some uniform guidelines to guide practitioners in the rapid proliferation of SABR.

\section{CURRENT GUIDELINES FOR DOSE PRESCRIPTION IN CONVENTIONALLY FRACTIONATED RT AND SABR}

In radical, conventional, fractionated RT, the TTD is prescribed according ICRU guidelines at the planning target volume (PTV) ( 37 ). The PTV comprises the tumor with margins for microscopic extension (margin from gross tumor volume, GTV, to clinical target volume, CTV) and uncertainties of patient positioning, interobserver variation, treatment delivery, and imaging (margin from CTV to PTV). Typically, the dose distribution within the PTV is relatively homogeneous, in the range of $95 \%$ to $107 \%$ of the prescribed dose. The TTD in SABR is also prescribed at the rim of the PTV, but it differs from conventional fractionated RT in that the dose distribution within the PTV is deliberately heterogeneous. The maximum dose often exceeds $130 \%$ of the prescribed dose.[19,28] The aim of the steep dose gradient at the rim of the PTV is to achieve optimal sparing of nearby OARs while simultaneously allowing for dose escalation within the PTV in order to achieve maximal TCP. Typically, the used GTV-CTV and CTV-PTV margins are minimized by the use of dedicated onboard imaging and patient immobilization devices.

\section{LIMITATIONS OF DOSE PRESCRIPTION BASED ON TUMOR VOLUME}

Currently, several clinical trials with SABR are ongoing. In these studies, a fixed dose level is prescribed to the PTV in the same way for every patient. During treatment plan- 
ning, the OAR dose constraints are respected and, if necessary, nearby OARs are actively spared. If the OAR is very close to the PTV, there is an insurmountable conflict because it is technically not feasible to respect the OAR dose-volume tolerance while simultaneously achieving sufficient PTV coverage. Several potential solutions are chosen in daily practice:

1. A more fractionated approach is chosen in order to increase the therapeutic ratio. $\mathrm{SABR}$ is delivered as conventionally fractionated $\mathrm{RT}$, which may result in protracted schemes of multiple fractions over several weeks. However, long fractionation schedules are undesirable in a metastatic setting where disease progression at other metastatic sites may occur within months. One to five fractions are more desirable for patient convenience.

2. Underdosage of the PTV is accepted in a region near the OAR while the number of fractions remains unchanged. This may result in a decreased TCP. Moreover, when reporting SABR, it is often unclear exactly what dose has been delivered in the PTV and in the OAR.

3. Underdosage of the PTV is achieved by reducing the number of fractions in order to respect the OAR constraint.

4. PTV coverage is not compromised by altering the dose prescription, although the OAR constraint is not respected, which results in increased NTCP rates.

Evidently, these four solutions have the substantial clinical disadvantages of protracted treatment duration, decreased TCP, and increased NTCP. Another disadvantage of SABR dose prescription based on the tumor volume is its application in phase I dose escalation trials. A paradox may occur because tumors typically have different volumes. SABR of large tumors causes a large volume of the nearby OAR to be irradiated at certain doses. A patient with a large tumor volume in a phase I study in a low-dose treatment arm may have a higher NTCP than a patient with a small tumor volume in a high-dose treatment arm. For example, with the SABR of brain metastasis NTCP (eg, radionecrosis) is dependent on the $V_{12 G y}$ and increases rapidly above $10 \%$ if the $V_{12 G y}$ is $10 \mathrm{~cm} 3$ or larger. $[6,35,36]$ The $V_{12 G y}$ of nearby uninvolved brain tissue may be above $10 \mathrm{~cm} 3$ in the low-dose arm with large-volume metastasis and less than $10 \mathrm{~cm} 3$ in the high-dose arm with a small-volume metastasis. This was also shown in a randomized trial on SABR in brain metastases, in which a $1 \mathrm{~mm}$ GTV-PTV margin was compared with a $3 \mathrm{~mm}$ GTV-PTV margin with a primary endpoint of a 12-month local control.[38] Dose prescription was based on the maximum diameter of the PTV as shown in Table 1 . In the $3 \mathrm{~mm}$ GTV-PTV arm, prescription dose was generally lower, with an equal GTV diameter as that of a $1 \mathrm{~mm}$ GTV-PTV arm. BED and TCP are calculated based on the method described by Wiggenraad et al.[39] with an $\alpha / \beta$-ratio of $12 \mathrm{~Gy}$. In this study, the median GTV in both arms was the same $\left(0.38 \mathrm{~cm} 3\right.$ in both arms). The median $V_{12 G y}$, which corresponds with NTCP, was higher in the $3 \mathrm{~mm}$ arm compared with the $1 \mathrm{~mm}$ arm: $11.4 \mathrm{~cm}^{3}$ vs $6.0 \mathrm{~cm}^{3}$. The therapeutic ratio was higher in the $1 \mathrm{~mm}$ margin arm with a higher prescribed dose 
to the PTV and TCP and a lower $\mathrm{V}_{12 \mathrm{~Gy}}$ and NTCP.[Table 1] Therefore IDP, especially in a fractionated approach, may increase the therapeutic ratio of SABR in large brain metastases.

Table 1 SABR dose prescription schedule for brain metastases in a randomized trial comparing outcomes for $1 \mathrm{~mm}$ vs $3 \mathrm{~mm}$ GTV-PTV margins.

\begin{tabular}{llllll}
$\begin{array}{l}\text { PTV } \\
\text { diameter, } \\
\mathbf{~ c m}\end{array}$ & $\begin{array}{l}\text { GTV diameter } \\
\text { with } \mathbf{1 m m} \\
\text { GTV-PTV } \\
\text { margin, } \mathbf{~ c m}\end{array}$ & $\begin{array}{l}\text { GTV diameter } \\
\text { with } \mathbf{3 m m} \\
\text { GTV-PTV } \\
\text { margin, } \mathbf{~ c m}\end{array}$ & $\begin{array}{l}\text { Prescribed } \\
\text { dose }\end{array}$ & $\begin{array}{l}\text { BED } \\
\text { (Gy })\end{array}$ & $\begin{array}{l}\text { TCP, } \\
\%\end{array}$ \\
\hline$<2.0$ & $<1.8$ & $<1.4$ & $\begin{array}{l}\text { 1 fraction of } \\
24 \text { Gy }\end{array}$ & 72 & 90 \\
\hline $2.0-2.9$ & $1.8-2.7$ & $1.4-2.3$ & $\begin{array}{l}1 \text { fraction of } \\
18 \text { Gy }\end{array}$ & 45 & 65 \\
\hline $3.0-3.9$ & $2.8-3.7$ & $2.4-3.3$ & $\begin{array}{l}1 \text { fraction of } \\
15 \text { Gy }\end{array}$ & 34 & 40 \\
\hline
\end{tabular}

Legend: $B E D=$ biologically effective dose; GTV=gross tumor volume; PTV=planning target volume; $\mathrm{SABR}=$ stereotactic ablative body radiotherapy; $\mathrm{TCP}=$ tumor control probability.

\section{ISOTOXIC DOSE PRESCRIPTION BASED ON OAR TOLERANCE}

We propose an isotoxic dose prescription (IDP) strategy to overcome the limitations of current tumor volume-based dose prescription protocols, especially in the design of phase I SABR-based clinical trials. In IDP, the SABR dose is prescribed in relation to a volume of a dominant OAR based on an acceptable normal tissue complication probability (NTCP) level. The TTD is escalated up to the technically highest achievable level but within a specified range of minimal TCP. If the TCP is unacceptably low because of limitations by NTCP, more fractionated SABR will allow a more favorable therapeutic ratio and the allowance of a higher TCP with a constant low NTCP. In the context of IDP and NTCP, it is essential to achieve international consensus in OAR delineation and the reporting of RT dose in OAR.[40] Moreover, IDP will help to determine the exact OAR tolerance dose in a prospective setting and will validate current predictive NTCP models.[41,42] If OAR dose volume tolerance levels are unknown for a certain fraction scheme, phase I studies may discern this. There are several potential designs for phase I studies with IDP:

1. The TTD is escalated until a predefined OAR dose volume tolerance level is met (with an accompanying NTCP rate). The volume of the OAR in relation to which the dose is 
prescribed is fixed, and the number of fractions is fixed. An example of this strategy is illustrated in Figure 3 .

2. The OAR volume in relation to which the dose is prescribed is escalated while maintaining the RT dose in the OAR and the number of fractions fixed.

3. The number of fractions is increased until the predefined OAR dose volume constraint is met. The RT dose for each fraction is fixed, and the volume of the OAR to which the dose is prescribed is fixed.

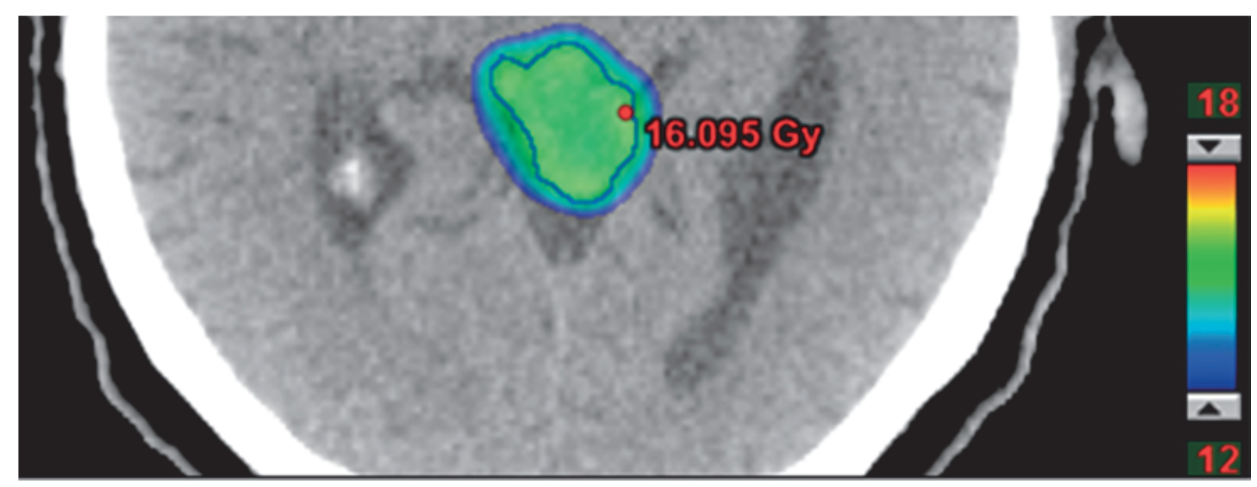

Figure 3 Potential gain in tumor complication probability (TCP) with isotoxic fractionated dose prescription in a patient with a large brain metastasis.

Legend: Treatment plan (Eclipse, Varian, Palo Alto, CA) of a single fraction of 15 Gy with stereotactic ablative body radiotherapy of a large brain metastasis with a diameter of $28 \mathrm{~mm}$. The illustrated radiation doses are in the range of 12 to $18 \mathrm{~Gy}$. The TCP of a single dose of $15 \mathrm{~Gy}$ is $40 \%$. In this treatment plan, the $\mathrm{V} 12 \mathrm{~Gy}$ is $5 \mathrm{~cm} 3$ . If isotoxic dose prescription (IDP) is applied and the $V 12 \mathrm{~Gy}$ is escalated up to $10 \mathrm{~cm} 3$, the total tumor dose increases to 18.9 Gy with a TCP of $65 \%$. Thus, the gain in TCP for this brain metastasis with IDP is $25 \%$ if an NTCP of $10 \%$ on symptomatic radionecrosis is accepted. Wiggenraad calculated TCP estimates based on the review article.[39]

For a phase I study, a time-to-event continual reassessment methodology (TiTe-CRM) design is suitable, which utilizes a Bayesian approach to reassess the dose on all patients in the study and permits short- and long-term adverse events to be incorporated as an alternative approach to a commonly used $3 \times 3$ designs. [43,44] For the design of a phase I study, the OAR constraint based on available literature is determined. Next, the TCP is calculated using an in silico study with the available treatment planning and delivery technique and using the margins of several tumor sizes. If there is no potential with the current technique and GTV-PTV margins, critical evaluation of the GTV-PTV margins will be needed to investigate whether a decrease in the margins is safe at the treatment department. This will provide the potential for further dose escalation with equal NTCP. If the TCP is still unsatisfactory $(<90 \%)$, more fractionated approaches are used. However, the OAR constraint of common used fractionation schedules is often relatively well described but is often unknown for uncommon used fractionation schedules. For example, the $\mathrm{V}_{12 \mathrm{~Gy}}$ for a common used single-fraction SABR in brain metastases 
is well described, but the OAR constraint for a five- or 10-fraction approach is poorly documented. It is not trivial to convert the particular OAR constraint from a given fractionation scheme into an equivalent constraint for a new scheme. Therefore, it is important to perform a phase I study for fractionated approaches in order to carefully assess the OAR tolerance level.

Predictive modeling studies for IDP have already been published. In an in silico trial for advanced NSCLC, an individualized isotoxic dose prescription enabled therapeutic gains (ie, TTD escalation) in 79\% of case patients compared with conventionally prescribed fractionated RT ( 45 ). This was achieved by altering the dose per fraction and/or the number of fractions based on a clinically relevant mean or a maximum OAR tolerance dose for the uninvolved healthy lungs, brachial plexus, spinal cord, esophagus, and heart. Two different approaches were described in order to assess the predicted gain in a tumor-effective dose, either based on an IDP approach or on a maximum tolerable dose. Clinical experience has also been gained with IDP. In a prospective single-arm study in stage I to III NSCLC, a radical dose of chemotherapy was prescribed using a sequential approach by increasing the number of fractions until the first dose-limiting OAR tolerance level was met.[46] The observed toxicity rates were acceptable (grade 3 or more toxicity was $24 \%$ ), and survival was comparable with the results achieved with historical controls of concurrent radiotherapy and chemotherapy. In a predictive modeling study, the authors had already published an expected increase in TCP of $25 \%$ with this approach.[47] Recently, favorable clinical results were published with IDP in NSCLC in a concurrent radiotherapy and chemotherapy setting.[48] The observed gain in a therapeutic ratio encourages further exploration into this approach for disease entities other than NSCLC with fractionated approaches, but also in extreme hypofractionated approaches with SABR. Fractionated approaches (eg, up to 30 fractions) are needed when the tumor is abutting a radiosensitive organ with a relatively low tolerance dose for serious complications. Examples are gastro-intestinal organs such as the stomach (eg, bleeding) and bowel (eg, perforation). Obviously, when employing more fractions at a lower fraction size, the dose to the GTV is to a lesser extent limited by the maximum tolerable dose to the surrounding radiosensitive organs, and it may be possible to cover the GTV to an ablative BED of 100 Gy. For this means, a schedule of 12 fractions may not be sufficient, and more fractionated approaches may be needed to achieve a better therapeutic ratio. For designing prospective IDP trials with both conventional fractionated and more hypofractionated approaches, published tolerance dose of OARs should be used. The QUANTEC group has published comprehensive reports of known tolerance doses for conventional multiple fractionat approaches. [6] For example in the QUANTEC paper, the tolerance dose of the bowel for grade 3 or higher toxicity is a $V_{45 G y}$ value of less than $195 \mathrm{~cm}^{3}$ using a conventional fraction schedule with fractions of 2 Gy. For a hypofractionated approach, Lo and Timmermans have also published OAR constraints.[35,36] For example, the tolerance dose of the small bowel in a single SABR 
fraction is only a $V 9.8 \mathrm{~Gy}$ value of less than $5 \mathrm{~cm}^{3}$.[36] If the therapeutic ratio is unsatisfactory with a hypofractionated SABR IDP schedule, a treatment schedule with more fractions IDP is used. The OAR tolerance dose for this multiple fractions schedule may be unknown. Then a phase I study is needed to determine the OAR tolerance level for this specific fractionation schedule. Another option is to choose a multiple fractions schedule from which the OAR tolerance dose is known, such as a conventional 2 Gy fractionation schedule. In Maastricht, an in silico study for SABR in brain metastases is ongoing, which aims to explore the theoretical therapeutic gain obtained by using IDP followed by a prospective clinical trial to validate the predictive modeling with clinically observed outcomes.

\section{FUTURE CHALLENGES}

By further applying IDP, more evidence becomes available regarding the exact tolerance doses of OARs. This may pave the way towards personalized medicine where shared decision-making aids physicians and patients in making evidence-based treatment decisions and balancing the benefit and toxicity of SABR in an individually tailored manner.[49] The TCP achieved by IDP may depend on the technology and the size of the margins that are used. Future research will focus not only on exploration of IDP in SABR but also on improving the prediction of outcomes based on multifactorial decision support systems.[50] An example of multifactorial predictive models can be found at www.predictcancer.org. Another area of research is the further improvement of radiation modalities such as particle therapy (eg, protons and carbon ions), which may further increase the therapeutic ratio of IDP.[51,52] With these techniques, an even higher degree of normal tissue sparing may be achieved, which could potentially lead to a reduction of the number of fractions, making these modalities less expensive per treatment course, with implications for increasing the number of patients who could benefit from them.

\section{CONCLUSION}

Isotoxic dose prescription is a new paradigm in stereotactic ablative radiotherapy. The radiation dose is prescribed based on nearby organs-at-risk tolerance dose. Simultaneously, the prescribed total tumor dose is maximized to the technically highest achievable level to increase the probability of tumor control. This strategy has the potential to overcome several limitations of traditional radiotherapy dose prescription based on tumor volume, and this strategy is expected to improve the overall therapeutic ratio of tumor control and toxicity. 


\section{REFERENCES}

[1] Beasley M, Driver D, Dobbs HJ. Complications of radiotherapy: improving the therapeutic index. Cancer Imaging. 2005;5:78-84.

[2] van Elmpt W, Öllers $M$, Velders $M$, et al. Transition from a simple to a more advanced dose calculation algorithm for radiotherapy of non-small cell lung cancer (NSCLC): implications for clinical implementation in an individualized dose-escalation protocol. Radiother Oncol. 2008;88(3):326-334.

[3] De Ruysscher D, van Baardwijk A, Steevens J, et al. Individualised isotoxic accelerated radiotherapy and chemotherapy are associated with improved long-term survival of patients with stage III NSCLC: a prospective population- based study. Radiother Oncol. 2012;102(2):228-233.

[4] Bentzen SM, Constine LS, Deasy JO, et al. Quantitative Analyses of Normal Tissue Effects in the Clinic (QUANTEC): an introduction to the scientific issues. Int J Radiat Oncol Biol Phys. 2010;76(3 Suppl):S3-S9.

[5] Jackson A, Marks LB, Bentzen SM, et al. The lessons of QUANTEC: recommendations for reporting and gathering data on dose-volume dependencies of treatment outcome. Int J Radiat Oncol Biol Phys. 2010;76(3 Suppl):S155-S160.

[6] Marks LB, Yorke ED, Jackson A, et al. Use of normal tissue complication probability models in the clinic. Int J Radiat Oncol Biol Phys. 2010;76(3 Suppl):S10-S19.

[7] Kirkpatrick JP, Kelsey CR, Palta M, et al. Stereotactic body radiotherapy: a critical review for nonradiation oncologists. Cancer. 2014;120(7):942-954.

[8] Senan S, Palma DA, Lagerwaard FJ. Stereotactic ablative radiotherapy for stage I NSCLC: Recent advances and controversies. J Thorac Dis. 2011;3(3):189-196.

[9] de Vin T, Engels B, Gevaert T, Storme G, De Ridder M. Stereotactic radiotherapy for oligometastatic cancer: a prognostic model for survival. Ann Oncol. 2014;25(2):467-471.

[10] Bentzen SM, Dörr W, Gahbauer R, et al. Bioeffect modeling and equieffective dose concepts in radiation oncology--terminology, quantities and units. Radiother Oncol. 2012;105(2):266-268.

[11] Leksell L. The stereotaxic method and radiosurgery of the brain. Acta Chir Scand.1951;102(4):316-319.

[12] Palma DA, Salama JK, Lo SS, et al. The oligometastatic state-separating truth from wishful thinking. Nat Rev Clin Oncol. 2014;11(9):549-557.

[13] Tree AC, Khoo VS, Eeles RA, et al. Stereotactic body radiotherapy for oligometastases. Lancet Oncol. 2013;14(1):e28-e37.

[14] Zindler JD, Rodrigues G, Haasbeek CJ, et al. The clinical utility of prognostic scoring systems in patients with brain metastases treated with radiosurgery. Radiother Oncol. 2013;106(3):370-374.

[15] Kocher M, Soffietti R, Abacioglu U, et al. Adjuvant whole-brain radiotherapy versus observation after radiosurgery or surgical resection of one to three cerebral metastases: results of the EORTC 2295226001 study. J Clin Oncol. 2011;29(2):134-141.

[16] Palma D, Visser O, Lagerwaard FJ, Belderbos J, Slotman BJ, Senan S. Impact of introducing stereotactic lung radiotherapy for elderly patients with stage I non-small-cell lung cancer: a population-based timetrend analysis. J Clin Oncol. 2010;28(35):5153-5159.

[17] Senthi S, Lagerwaard FJ, Haasbeek CJ, Slotman BJ, Senan S. Patterns of disease recurrence after stereotactic ablative radiotherapy for early stage non-smallcell lung cancer: a retrospective analysis. Lancet Oncol. 2012;13(8):802-809.

[18] Crabtree T, Puri V, Timmerman R, et al. Treatment of stage I lung cancer in high-risk and inoperable patients: comparison of prospective clinical trials using stereotactic body radiotherapy (RTOG 0236), sublobar resection (ACOSOG Z4032), and radiofrequency ablation (ACOSOG Z4033). J Thorac CardiovasC Surg. 2013;145(3):692-699.

[19] Hurkmans CW, Cuijpers JP, Lagerwaard FJ, et al. Recommendations for implementing stereotactic radiotherapy in peripheral stage IA non-small cell lung cancer: report from the Quality Assurance Working Party of the randomised phase III ROSEL study. Radiat Oncol. 2009;12:1.

[20] Postow MA, Callahan MK, Barker CA, et al. Immunologic correlates of the abscopal effect in a patient with melanoma. N Engl J Med. 2012;366(10):925-931. 
[21] Stamell EF, Wolchok JD, Gnjatic S, Lee NY, Brownell I. The abscopal effect associated with a systemic anti-melanoma immune response. Int J Radiat Oncol Biol Phys. 2013;85(2):293-295.

[22] Rödel F, Frey B, Multhoff G, Gaipl U. Contribution of the immune system to bystander and nontargeted effects of ionizing radiation. Cancer Lett. 2013:S0304-S3835.

[23] Zegers CM, Rekers NH, Quaden DH, et al. Radiotherapy combined with the immunocytokine L19-IL2 provides long-lasting antitumor effects. Clin Cancer Res. 2015;21(5):1151-1160.

[24] Lo SS, Loblaw A, Chang EL, et al. Emerging applications of stereotactic body radiotherapy. Future Oncol. 2014;10(7):1299-1310.

[25] Palma DA, Verbakel WF, Otto K, Senan S. New developments in arc radiation therapy: a review. Cancer Treat Rev. 2010;36(5):393-399.

[26] Salama JK, Milano MT. Radical Irradiation of Extracranial Oligometastases. J Clin Oncol. 2014:32(26):2902-2912.

[27] Sheehan JP, Yen CP, Lee CC, Loeffler JS. Cranial Stereotactic Radiosurgery: Current Status of the Initial Paradigm Shifter. J Clin Oncol. 2014:32(26):2836-2846.

[28] Seung SK, Larson DA, Galvin JM, et al. American College of Radiology (ACR) and American Society for Radiation Oncology (ASTRO) Practice Guideline for the Performance of Stereotactic Radiosurgery (SRS). Am J Clin Oncol. 2013;36(3):310-315.

[29] Ong CL, Palma D, Verbakel WF, Slotman BJ, Senan S. Treatment of large stage I-II lung tumors using stereotactic body radiotherapy (SBRT): planning considerations and early toxicity. Radiother Oncol. 2010;97(3):431-436.

[30] Corradetti MN, Haas AR, Rengan R. Central-airway necrosis after stereotactic body-radiation therapy. $N$ Engl J Med. 2012;366(24):2327-2329.

[31] Barney BM, Olivier KR, Macdonald OK, Fong de los Santos LE, Miller RC, Haddock MG. Clinical outcomes and dosimetric considerations using stereotactic body radiotherapy for abdominopelvic tumors. Am J Clin Oncol. 2012;35(6):537-542.

[32] Sahgal A, Weinberg V, Ma L, et al. Probabilities of radiation myelopathy specific to stereotactic body radiation therapy to guide safe practice. Int J Radiat Oncol Biol Phys. 2013;85(2):341-347.

[33] Sahgal A, Whyne CM, Ma L, et al. Vertebral compression fracture after stereotactic body radiotherapy for spinal metastases. Lancet Oncol. 2013;14(8):e310-e320.

[34] Wu AJ, Williams E, Modh A, et al. Dosimetric predictors of esophageal toxicity after stereotactic body radiotherapy for central lung tumors. Radiother Oncol. 2014;112(2):267-271.

[35] Lo SS, Sahgal A, Chang EL, et al. Serious complications associated with stereotactic ablative radiotherapy and strategies to mitigate the risk. Clin Oncol (R Coll Radiol). 2013;25(6):378-387.

[36] Timmerman RD. An overview of hypofractionation and introduction to this issue of seminars in radiation oncology. Semin Radiat Oncol. 2008;18(4):215-222.

[37] ICRU Report 83: Prescribing, recording and reporting intensity-modulated photon-beam therapy (IMRT). J ICRU. 2010;10(1):10.1093.

[38] Kirkpatrick JP, Wang Z, Sampson JH, et al. Defining the optimal planning target volume in image-guided stereotactic radiosurgery of brain metastases: results of a randomized trial. Int J Radiat Oncol Biol Phys. 2015;91(1):100-108.

[39] Wiggenraad R, Verbeek-de Kanter A, Kal HB, Taphoorn M, Visser T, Struikmans H. Dose-effect relation in stereotactic radiotherapy for brain metastases: A systematic review. Radiother Oncol. 2011;98(3):292297.

[40] Brouwer CL, Steenbakkers RJ, Gort E, et al. Differences in delineation guidelines for head and neck cancer result in inconsistent reported dose and corresponding NTCP. Radiother Oncol. 2014;111(1):148152.

[41] Park C, Papiez L, Zhang S, Story M, Timmerman RD. Universal survival curve and single fraction equivalent dose: useful tools in understanding potency of ablative radiotherapy. Int J Radiat Oncol Biol Phys. 2008;70(3):847-852. 
[42] Daly ME, Luxton G, Choi CY, et al. Normal tissue complication probability estimation by the LymanKutcher-Burman method does not accurately predict spinal cord tolerance to stereotactic radiosurgery. Int J Radiat Oncol Biol Phys. 2012;82(5):2025-2032.

[43] Cheung YK1, Chappell R. Sequential designs for phase I clinical trials with late-onset toxicities. Biometrics. 2000;56(4):1177-1182.

[44] Pijls-Johannesma M, van Mastrigt G, Hahn SM, et al. A systematic methodology review of phase I radiation dose escalation trials. Radiother Oncol. 2010;95(2):135-141.

[45] Hoffmann AL, Troost EG, Huizenga H, Kaanders JH, Bussink J. individualized dose prescription for hypofractionation in advanced non-smallcell lung cancer radiotherapy: an in silico trial. Int J Radiat Oncol Biol Phys. 2012;83(5):1596-1602.

[46] Baardwijk A, Wanders S, Boersma L, et al. Mature results of an individualized radiation dose prescription study based on normal tissue constraints in stages I to III non-small-cell lung cancer. J Clin Oncol. 2010;28(8):1380-1386.

[47] Baardwijk A, Bosmans G, Bentzen SM, et al: Radiation dose prescription for non-small-cell lung cancer according to normal tissue dose constraints: An in silico clinical trial. Int J Radiat Oncol Biol Phys. 2008;71(4):1103-1110.

[48] Reymen B, van Baardwijk A, Wanders R, et al. Long-term survival of stage T4NO-1 and single station IIIAN2 NSCLC patients treated with definitive chemo-radiotherapy using individualised isotoxic accelerated radiotherapy (INDAR). Radiother Oncol. 2014;110(3):482-487.

[49] Oberije C, Nalbantov G, Dekker A, et al. A prospective study comparing the predictions of doctors versus models for treatment outcome of lung cancer patients: A step toward individualized care and shared decision making. Radiother Oncol. 2014;112(1):37-43.

[50] Lambin P, van Stiphout RG, Starmans MH, et al. Predicting outcomes in radiation oncologymultifactorial decision support systems. Nat Rev Clin Oncol. 2013;10(1):27-40.

[51] Williams TM, Maier A. Role of stereotactic body radiation therapy and proton/carbon nuclei therapies. Cancer J. 2013;19(3):272-281.

[52] Roelofs E, Engelsman M, Rasch C, et al. Results of a multicentric in silico clinical trial (ROCOCO): comparing radiotherapy with photons and protons for non-small cell lung cancer. J Thorac Oncol. 2012;7(1):165-176.

[53] Joiner M, van der Kogel A. Basic Clinical Radiobiology. 4th edition. London, United Kingdom: Hodder Arnold; 2009. 



\section{Chapter}

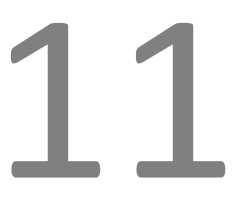

\section{Individualized isotoxic dose prescription for stereotactic radiotherapy in large brain metastases: an in-silico study}




\section{ABSTRACT}

Introduction The 12-month local tumor control probability (TCP) of single-fraction stereotactic radiosurgery (SRS) in large brain metastases (BM) with $4 \mathrm{~cm}$ diameter is about $42 \%$ (www.predictcancer.org). This in-silico study tests the hypothesis that isotoxic dose prescription (IDP) has the potential to improve the effectiveness of SRS in large BM significantly while respecting a low risk of radionecrosis.

Materials and Methods A treatment-planning study with 8 perfectly spherical and 46 clinically realistic gross tumor volume (GTV) shapes was conducted. The effects of GTV size (0.5-4 cm diameter), set-up margins $(0,1$, and $2 \mathrm{~mm})$, and beam arrangements (coplanar vs non-coplanar) on the IDP dose level and the predicted TCP for singlefraction and five-fraction SRS schemes were assessed. For single-fraction and fivefraction IDP dose-volume constraints of $V_{12 G y}=10 \mathrm{~cm}^{3}$ and a $V_{20 G y}=20 \mathrm{~cm}^{3}$ were used, respectively, to limit the risk of radionecrosis to $10 \%$.

Results In BM of $4 \mathrm{~cm}$ in diameter, the maximum achievable single-fraction IDP dose was 14 Gy compared to 15 Gy for standard SRS dose prescription, with respective TCPS of $32 \%$ and $42 \%$. Fractionated SRS with IDP was needed to improve the TCP. For fivefraction IDP, a maximum predicted TCP of $68 \%$ was achieved by exploiting non-coplanar beams and a $1 \mathrm{~mm}$ set-up margin.

Conclusions With five-fraction IDP, treatment effectiveness is predicted to increase from $42 \%$ up to $68 \%$ TCP compared to standard single-fraction SRS. More fractions are needed to further improve the therapeutic ratio under isotoxic conditions. 


\section{INTRODUCTION}

In stereotactic radiosurgery (SRS) for brain metastases (BM), the dose is generally prescribed according to a risk-adapted approach depending on the size of the planning target volume (PTV): for smaller PTVs higher SRS doses are prescribed than for larger PTVs with the aim to limit toxicity to acceptable levels in large BM.[1] In Radiation Therapy Oncology Group (RTOG) study 90-05, the maximum tolerated single-fraction dose for BM with a diameter $>3 \mathrm{~cm}$ was $15 \mathrm{~Gy}$, as a higher dose of $18 \mathrm{~Gy}$ was associated with an unacceptably high rate of severe central nervous system toxicity of 50\%.[3] Recently, consensus was reached within the Netherlands for SRS dose prescriptions: a single dose of $24 \mathrm{~Gy}$ is prescribed to PTV sizes $<1 \mathrm{~cm}^{3}$ and the dose level is stepwise decreased to 21,18 and $15 \mathrm{~Gy}$ for PTV sizes between $1-10 \mathrm{~cm}^{3}$, between $10-20 \mathrm{~cm}^{3}$, and $>20 \mathrm{~cm}^{3}$, respectively. In clinical practice, SRS is used for inoperable BM up to a diameter of $4 \mathrm{~cm}$. The consequence of this PTV size-based dose prescription protocol is a 12-month local tumor control probability (TCP) of about $86 \%$ in small BM and a TCP of around 40\% in large BM.[4,5] Given the low TCP for large BM and taking into account that patients with large BM are often medically inoperable, there is a clear need for improvement of SRS in these patients, but not at the cost of an unacceptably high risk of toxicity. This is currently being investigated in phase I studies.[6] An alternative to PTV size-based dose prescription is isotoxic dose prescription (IDP).[7-14] The quintessence of this strategy is to increase the prescribed tumor dose while simultaneously respecting a constant normal tissue complication probability (NTCP) constraint that is considered clinically acceptable. Here, the prescribed dose is individually maximized until a predefined dose-volume limit for the nearby healthy tissue is reached. The IDP concept is different from the PTV size-based dose prescription approach, where fixed prescription doses are used that solely depend on the size of the target volume and for large BM do not respect the predefined dose-volume constraint for normal tissue. From previous studies of single-fraction SRS for BM, it is known that the risk of radionecrosis increases rapidly if the volume of the surrounding healthy brain tissue receiving at least $12 \mathrm{~Gy}$ is greater than $10 \mathrm{~cm}^{3}$ (that is, $V_{12 \mathrm{~Gy}}>10 \mathrm{~cm}^{3}$ ). [15-17] Apart from being dependent on the tumor prescription dose, the $V_{12 G y}$ also depends on the gross tumor volume-to-planning target-volume (GTV-PTV) margin used, as well as on the beam arrangement (i.e., coplanar vs non-coplanar) and the beam-shaping technique (dynamic conformal arc vs volumetric modulated arc) that affect the degree of dose conformity and the steepness of the dose gradient at the outer rim of the PTV.[18]

In this study, the hypothesis is tested that through IDP the predicted TCP in large BM up to $4 \mathrm{~cm}$ diameter can be improved from the disappointing low level of $42 \%$ that is obtained with a standard single SRS dose of 15 Gy while simultaneously respecting an acceptably low NTCP. Furthermore, the effects of GTV volume, different GTV-PTV margins, and beam arrangements on the predicted TCP are systematically assessed. $[4,19,20]$ Both 
single-fraction and fractionated stereotactic radiotherapy (FSRS) IDP schemes are considered to assess the effect of fractionation.

\section{MATERIALS AND METHODS}

This study comprises 3 phases. First, the potential to increase TCP under isotoxic conditions is investigated for single-fraction and five-fraction IDP schemes, with artificial BM having spherical GTV shapes of different diameters $(0.5 \mathrm{~cm}-4.0 \mathrm{~cm}$, with stepwise increasing diameter of $0.5 \mathrm{~cm}$ ). This allows us to systematically derive empirical relationships between the GTV size and the maximum achievable predicted TCP as a function of the GTV-PTV margin and the beam arrangement. Second, these results are compared against clinically delivered SRS treatment plans in 46 patients with realistically shaped GTVs.

\section{Nominal treatment plans: target-volume definition and treatment-planning technique}

A computed tomography (CT) scan (Siemens Somatom Sensation Open, Erlangen, Germany) of an anonymized patient treated with SRS for BM was used to design nominal treatment plans having a dose prescription according to the Dutch consensus guidelines. The head and neck region was imaged until the claviculae with a slice thickness of $1 \mathrm{~mm}$. In the treatment-planning system (Eclipse version 11.0.42, Varian, Palo Alto, CA, USA), 8 perfectly spherical GTVs with diameters ranging from 0.5 to $4.0 \mathrm{~cm}$ in steps of $0.5 \mathrm{~cm}$ were contoured in the right parietal lobe so that the brain stem and optic system did not overlap with the PTV. For each GTV, a PTV was created by isotropic expansion with a margin of 0,1 , and $2 \mathrm{~mm}$. The dose prescription based on PTV size was a single fraction of 24, 21, 18, and 15 Gy for PTV sizes $<1,1-10,10-20 \mathrm{~cm}^{3}$, and 20-65 $\mathrm{cm}^{3}$. With the prescribed dose, $99 \%$ of the PTV was covered, while having a steep dose gradient outside the PTV for brain sparing and allowing large dose inhomogeneity within the PTV. Per the PTV, two 10 MV photon-based volumetric modulated arc therapy (VMAT, calculation grid size $1 \times 1 \times 1 \mathrm{~mm} 3$ ) plans were made by the same treatment planner (JS), one with 2 overlapping coplanar arcs at a couch angle of $0^{\circ}$ and one with 3 non-coplanar arcs having a couch angle of $0^{\circ}, 45^{\circ}$, and $315^{\circ}$ and a collimator angle of $30^{\circ}$ or $330^{\circ}$. In total, 48 treatment plans were generated. For each treatment plan, the $\mathrm{V}_{12 \mathrm{~Gy}}$ of the healthy brain minus the GTV was determined.

\section{Renormalized treatment plans: IDP based on normal tissue dose constraint}

For single-fraction IDP-based dose prescription, the nominal treatment plans with spherical GTVs were renormalized (by altering the monitor units) such that $\mathrm{V}_{12 \mathrm{~Gy}}=10$ 
$\mathrm{cm}^{3}$ for the healthy brain minus the GTV. The corresponding IDP dose levels for each of the 48 treatment plans were assessed for further analysis. The same procedure was used for the five-fraction IDP scheme, but a $V_{20 G y}=20 \mathrm{~cm}^{3}$ constraint for the healthy brain minus the GTV was used instead.[21] The predicted TCP was calculated from the IDP prescription dose by using a dose-response model that was statistically fitted to the data points of Wiggenraad et al.[4] (see Appendix). For calculation, plotting, and rescaling of the dose volume histograms (DVHs), in-house developed MATLAB scripts (Version 8.5; The MathWorks, Inc., Natick, NA, USA) were used.

\section{Validation of IDP results in clinically delivered SRS plans}

Since in clinical practice the GTVs of BM are not perfectly spherical and the plan quality may slightly vary due to inter- and intra-treatment planner differences, we compared the IDP dose levels obtained from the 48 treatment plans with perfectly spherical GTVs to those of clinical treatment plans comprising 46 consecutive patients who had been treated with SRS for a single BM at our institution between January 2013 and June 2014 with a dose of 15-24 Gy in 1-3 fractions. Patients had been considered eligible for SRS if they had less than five BM from metastasized solid primary tumors (e.g., non-small cell lung cancer, breast cancer, colorectal cancer, melanoma, and bladder cancer) at the pre-treatment contrast-enhanced magnetic resonance imaging (MRI) scan, a Karnofsky performance status of 70 or more, and extracranial treatment options. The selected cohort was identified from a database containing all patients who had been treated with SRS for newly diagnosed BM in our institution. Prior to treatment, a gadolinium contrast-enhanced MRI scan (3D T1-weighted sequence on a 1.5T Ingenia/Intera or 3T Achieva scanner, Philips Medical Systems, Eindhoven, Netherlands) was made with a slice thickness of $1 \mathrm{~mm}$. Patients had been immobilized with a frameless mask and underwent an iodide contrast-enhanced CT scan (Siemens Somatom Sensation Open, Erlangen, Germany) with a slice thickness of $1 \mathrm{~mm}$. For treatment-planning purposes, the MRI scan had been rigidly co-registered with the CT scan in Eclipse (Varian, Palo Alto, CA, USA). The BM had been delineated as GTV contours on the MRI scan and visually checked on the CT scan thereafter. A GTV-PTV margin of $2 \mathrm{~mm}$ had been applied. A VMAT (RapidArc) technique with $10 \mathrm{MV}$ coplanar beams had been used to design the dose distribution for delivery with a TrueBeam STX linear accelerator (Varian, Palo Alto, CA, USA). To derive the IDP dose levels for our study, these treatment plans were renormalized such that the constraints $V_{12 G y}=10 \mathrm{~cm}^{3}$ and $V_{20 G y}=20 \mathrm{~cm}^{3}$ were satisfied for the single- and five-fraction schemes, respectively.

\section{Potential value of IDP for phase I study}

We studied the potential of both single and five-fraction IDP to increase the TCP above the standard SRS dose prescription. An FSRS scheme of $5 \times 7$ Gy with the normal-tissue 
dose constraint of $V_{20 G y}=20 \mathrm{~cm}^{3}$ has been shown to be associated with an acceptable risk of radiation necrosis for patients with large BM.[20,21] Because this constraint has not yet been widely validated, we also investigated the sensitivity of the TCP for less stringent constraints for five fraction IDP, such as $V_{22 G y}=20 \mathrm{~cm}^{3}$ and $V_{24 G y}=20 \mathrm{~cm}^{3}$.

\section{RESULTS}

The application of a non-zero GTV-PTV margin results in an increase in the PTV size and may hence influence the PTV size-based dose prescription and thereby the therapeutic ratio. As indicated by the change in symbol shapes in Figure 1, applying a GTV-PTV margin of $1 \mathrm{~mm}$ instead of $0 \mathrm{~mm}$ resulted in lowering the nominal prescription dose from 21 to 18 Gy for a GTV diameter of $2.5 \mathrm{~cm}$, while for the other 7 GTV diameters, the prescribed dose did not change. Applying a GTV-PTV margin of $2 \mathrm{~mm}$ instead of $0 \mathrm{~mm}$ resulted in decreasing the nominal prescription dose from 24 to $21 \mathrm{~Gy}$, from 21 to 18 Gy, and from 18 to 15 Gy for GTV diameters of 1.0, 2.5, and $3.0 \mathrm{~cm}$, respectively, while for the other 5 GTV diameters, the prescribed dose remained the same.

Applying a non-zero GTV-PTV margin also results in an increase of the dose absorbed in uninvolved healthy brain tissue and therefore affects the NTCP and therapeutic ratio. When the single-fraction PTV size-based dose prescription protocol is applied to the 8 perfectly spherical GTVs, $V_{12 G y}$ shows a clear tendency to increase with increasing GTV size and increasing GTV-PTV margin and is generally lower for the non-coplanar beam arrangement than for the coplanar beams (Figure 1). From this figure, it is evident that for GTV diameters $>2 \mathrm{~cm}, V_{12 \mathrm{~Gy}}$ exceeds the $10 \mathrm{~cm}^{3}$ constraint level irrespective of the GTV-PTV margin or the beam arrangement. Furthermore, this figure shows that for a GTV diameter of $4 \mathrm{~cm}, V_{12 \mathrm{~Gy}}$ is reduced from $33 \mathrm{~cm}^{3}$ to $13 \mathrm{~cm}^{3}$ in case a GTV-PTV margin of $0 \mathrm{~mm}$ instead of $2 \mathrm{~mm}$ is used in combination with non-coplanar beams instead of coplanar beams. 

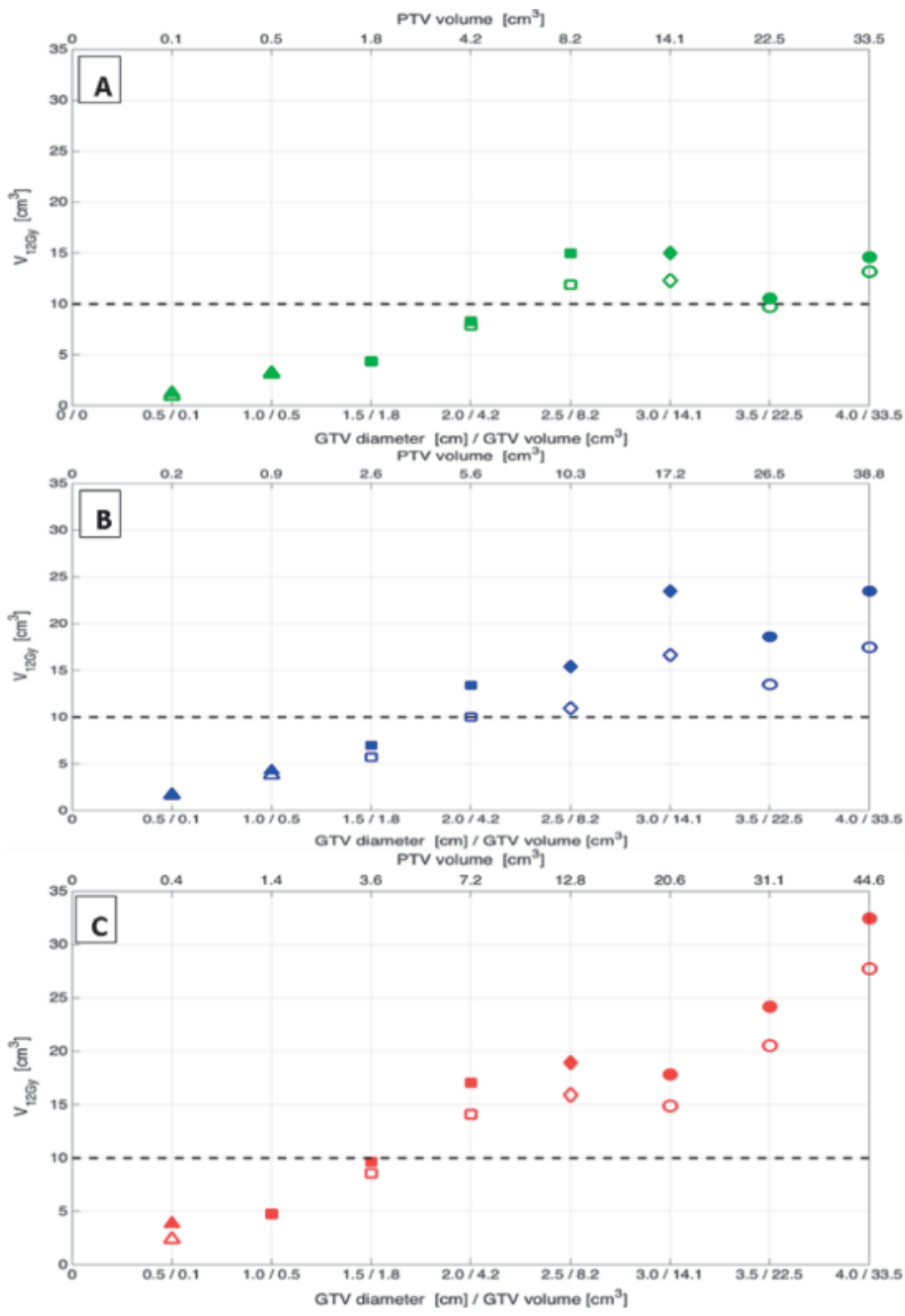

Figure 1 Commonly used risk-adapted dose prescription based on PTV size. The $\mathrm{V}_{12 \mathrm{~Gy}}$ as function of GTV size is presented for different GTV-PTV margins and beam arrangements.

Legend: The GTV-PTV margin: $0 \mathrm{~mm}(\mathrm{~A}), 1 \mathrm{~mm}(\mathrm{~B})$, and $2 \mathrm{~mm}(\mathrm{C})$. The open and filled symbols represent noncoplanar and coplanar beams, respectively. The single-fraction PTV size-based dose prescription: 24 Gy (triangle), $21 \mathrm{~Gy}$ (square), $18 \mathrm{~Gy}$ (diamond), and $15 \mathrm{~Gy}$ (circle). 


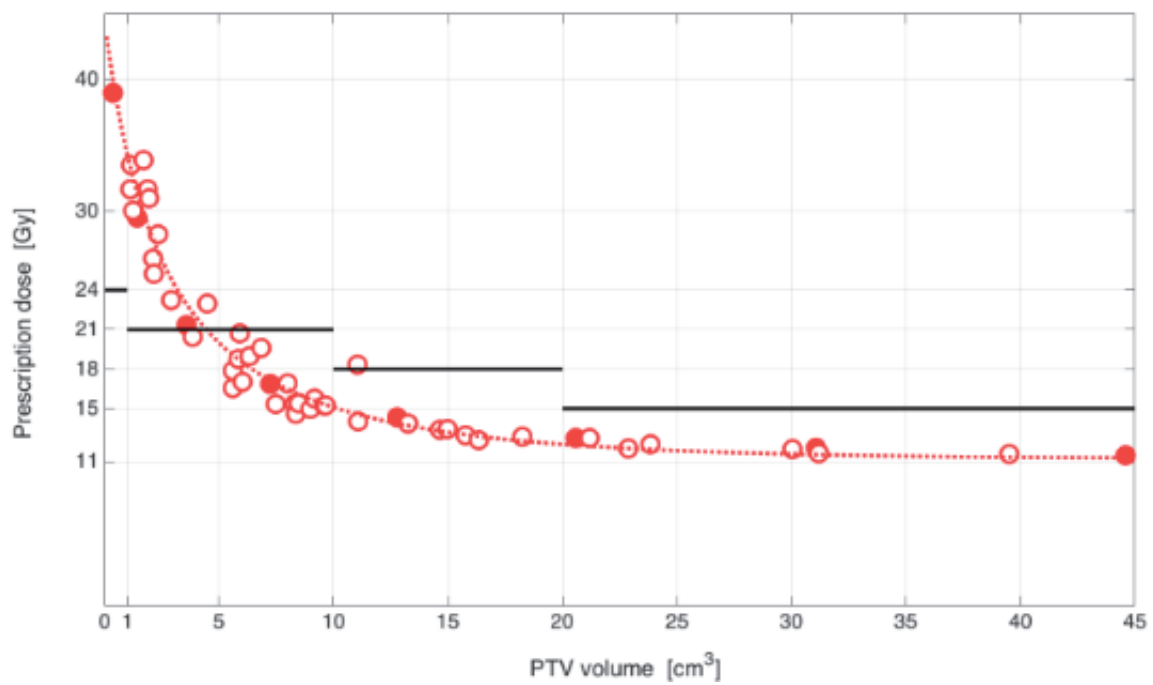

Figure $2 \mathrm{~A}$ comparison of the single-fraction IDP dose level with $\mathrm{V}_{12 \mathrm{~Gy}}=10 \mathrm{~cm}^{3}$ for coplanar beam arrangement and GTV-PTV margin of $2 \mathrm{~mm}$ between perfectly spherical GTVs (filled dots) and non-spherical GTVs of clinical plans (open dots).

Legend: The solid lines represent single-fraction PTV size-based dose prescription protocols. The dashed line represents a logistic regression model fitted to data of perfectly spherical GTVs.

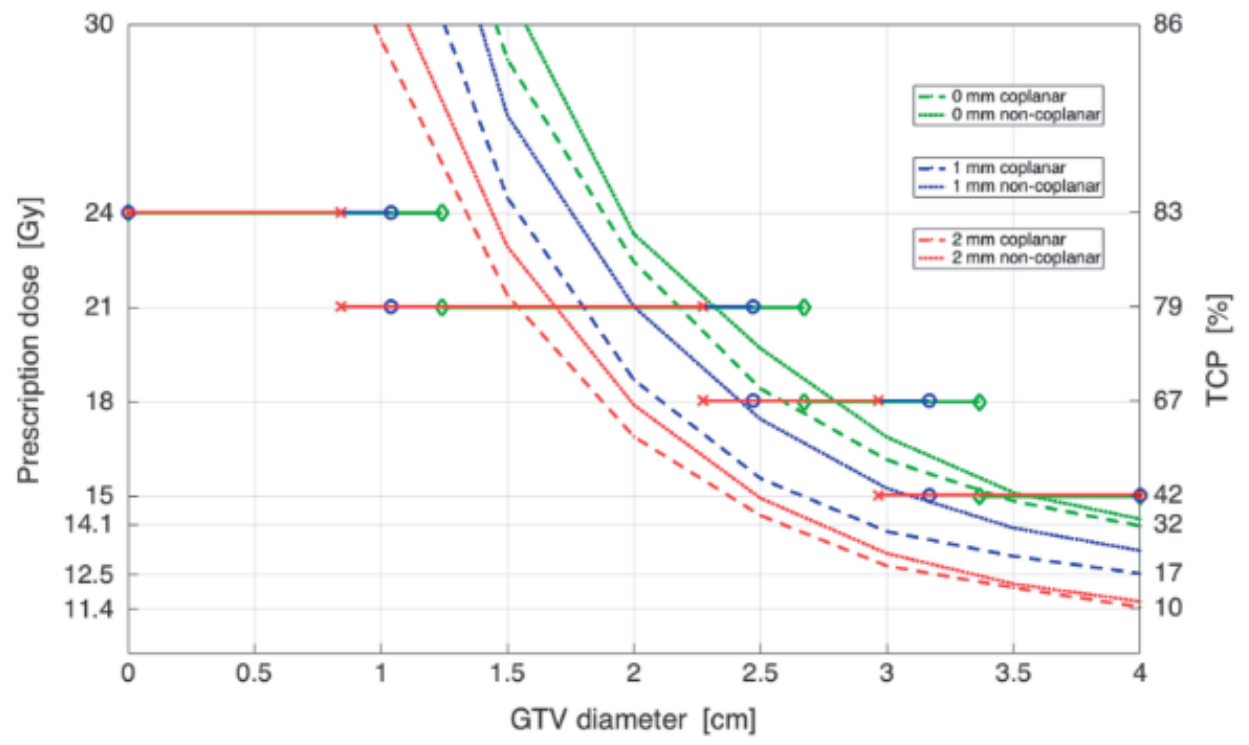

Figure 3 The prescribed dose and predicted TCP for single-fraction IDP with the $V_{12 G y}=10 \mathrm{~cm}^{3}$ constraint as a function of the GTV diameter for coplanar and non-coplanar beam arrangements with a GTV-PTV margin of 0$2 \mathrm{~mm}$ and spherical GTVs. A GTV-PTV margin enlargement results in an increase of the PTV size. An increase in the PTV size results in different cut-offs with a PTV size-based dose prescription with 24, 21, 18, and 15 Gy. The diamond (green line), circle (blue line), and cross (red line) represent the cut-offs with dose prescriptions with GTV-PTV margins of 0,1 , and $2 \mathrm{~mm}$, respectively. 
To test whether the single-fraction IDP dose levels derived for the spherical GTVs apply to the non-spherical GTVs of the clinical treatment plans, an empirical relationship between the PTV size of the spherical GTVs and the single-fraction IDP dose level was derived by fitting an exponential decay model to the data of the coplanar beam arrangement with a GTV-PTV margin of $2 \mathrm{~mm}$ (Figure 2). The same was done for the IDP dose of the 46 clinical treatment plans with non-spherical PTVs. It could be shown that there is no statistically significant difference between these fits. The median ( \pm SD) IDP dose difference between the spherical GTVs of the artificial treatment plans and the non-spherical GTVs of the clinical treatment plans was $0.25 \pm 1.70 \mathrm{~Gy}$ and ranged from 3.92-2.16 Gy.

As shown in Figure 3, for a $0 \mathrm{~mm}$ GTV-PTV margin, single-fraction IDP with the $\mathrm{V}_{12 \mathrm{~Gy}}=10$ $\mathrm{cm}^{3}$ constraint offers no potential for isotoxic dose escalation in spherical GTVs with diameters $>2 \mathrm{~cm}$, even when non-coplanar beams are used. For BM with a GTV diameter of $4 \mathrm{~cm}$, this approach achieved an IDP dose of $14.1 \mathrm{~Gy}$ with a significantly lower TCP of $32 \%$ compared to the $42 \%$ that was predicted for the PTV size-based dose prescription at $15 \mathrm{~Gy}$. Therefore, we have explored the potential of five fraction IDP to increase the TCP. For five-fraction IDP with the $V_{20 G y}=20 \mathrm{~cm}^{3}$ constraint, the predicted TCP for a GTV diameter of $4 \mathrm{~cm}$ was $73 \%, 68 \%$, and $50 \%$ when using a GTV-PTV margin of 0,1 and $2 \mathrm{~mm}$, respectively, with the non-coplanar beam arrangement. Using coplanar beams, the predicted TCPs were 69\%,60\%, and 42\%, respectively (Figure 4).

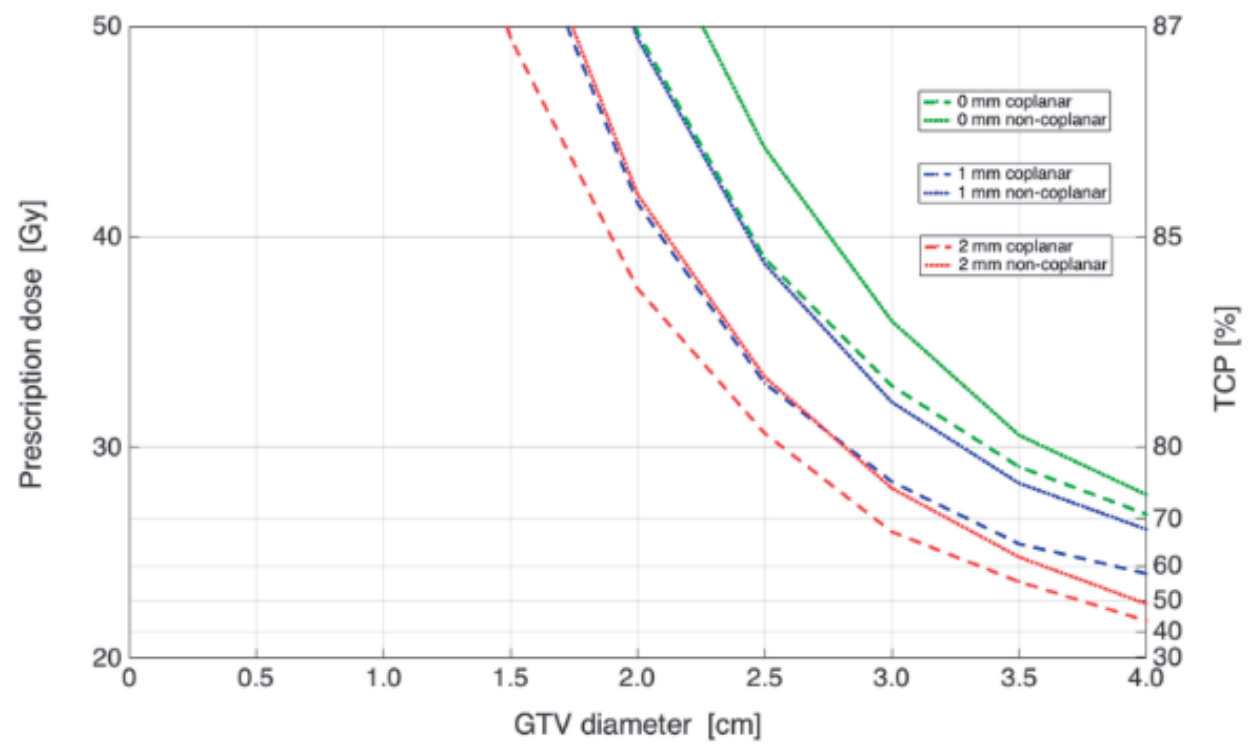

Figure 4 The prescribed dose and predicted TCP for 5 -fraction IDP with the $V_{20 G y}=20 \mathrm{~cm}^{3}$ constraint as a function of the GTV diameter for different GTV-PTV margins and beam arrangements. 
Exploiting a dedicated frameless mask in combination with advanced online imageguidance and a 6 degrees-of-freedom couch may render a setup accuracy of $1 \mathrm{~mm}$ feasible in clinical practice.[18] We found that the normal-tissue constraint of $V_{20 G y}=20$ $\mathrm{cm}^{3}$ needed to be relaxed to $V_{24 G y}=20 \mathrm{~cm}^{3}$ for the five-fraction IDP to escalate the TCP up to $80 \%$ in a spherical GTV of $4 \mathrm{~cm}$ diameter (Figure 5). This was achievable for cases where a $1 \mathrm{~mm}$ GTV-PTV margin is used in combination with the non-coplanar beam arrangement.

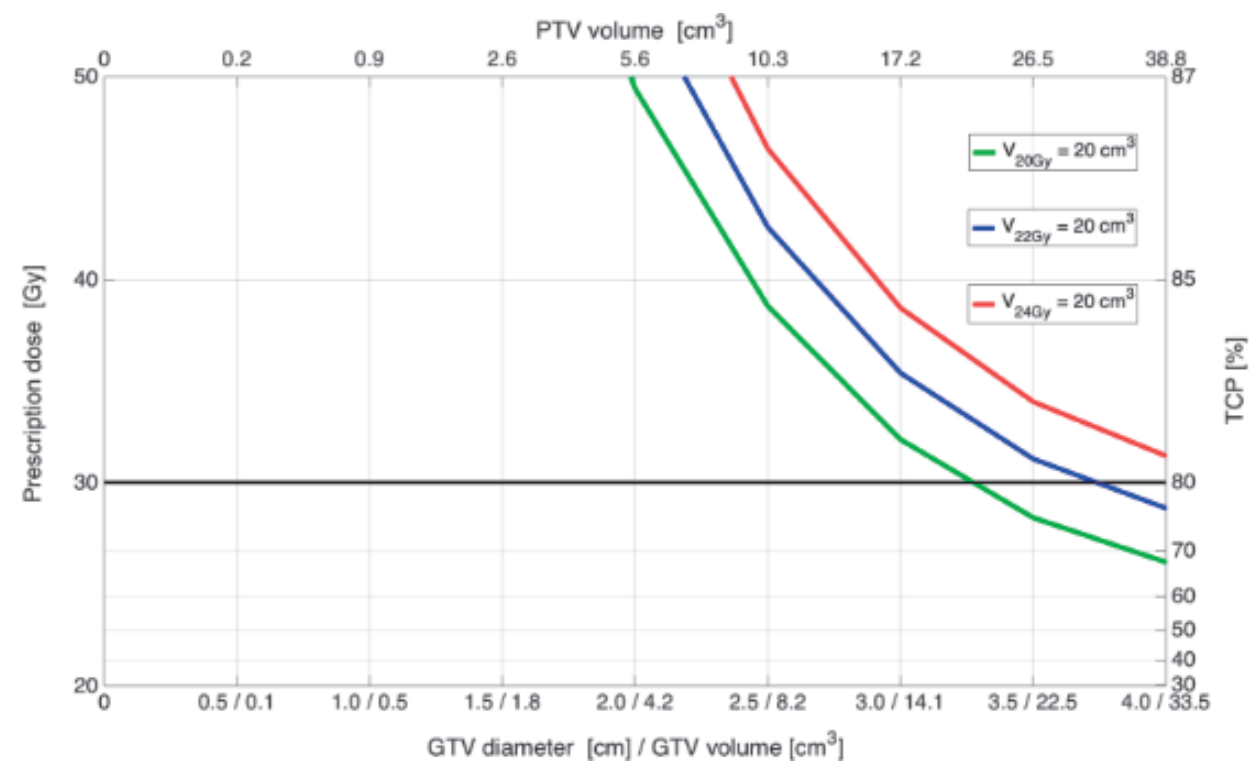

Figure 5 The prescribed dose and predicted TCP for 5-fraction IDP with $1 \mathrm{~mm}$ GTV-PTV margin and noncoplanar beams as a function of the GTV diameter for three different normal tissue dose constraints. Legend: The black horizontal solid line represents a SRS scheme of 5 daily fractions of 6 Gy up to a total dose of 30 Gy.[21]

\section{DISCUSSION}

In this in silico study, the potential of IDP was investigated for improving the TCP from $42 \%$ with a single fraction of $15 \mathrm{~Gy}$ in large BM up to $4 \mathrm{~cm}$ diameter, while simultaneously respecting an acceptably low NTCP limit. The concept of IDP is of clinical relevance for BM with a diameter of $2 \mathrm{~cm}$ or more, as the constraint of a $V_{12 G y}$ of $10 \mathrm{~cm}^{3}$ for the surrounding brain tissue is exceeded with SRS independent of the GTV-PTV margin and the beam arrangement with the current PTV-based dose prescription (Figure 1). In a large cohort of patients treated with SRS alone for a maximum of $3 \mathrm{BM}$, the median diameter of the BM was $2.3 \mathrm{~cm}$, so this study is of relevance for at least half of BM patients treated with SRS in daily clinical practice.[2] Despite avoiding a GTV-PTV margin 
and exploiting a coplanar beam arrangement, the single-fraction IDP SRS approach with the $V_{12 G y}=10 \mathrm{~cm}^{3}$ constraint for the nearby healthy brain tissue did not improve the predicted TCP over the standard SRS dose prescription with 15 Gy. As expected, fivefraction IDP had a better therapeutic ratio than single-fraction IDP. The predicted gain of from $32 \%$ to $73 \%$ in 1-year TCP using five-fraction IDP instead of single-fraction IDP is significant. Such gain is especially relevant for oligometastases patients treated with curative intent in whom ablation of metastases and hence maximization of TCP is the goal. For patients with a relatively short life expectancy (for example, 6 months) treated with palliative intent, a lower 1-year TCP could be considered acceptable. For these patients, a single-fraction approach having a relatively low 1-year TCP may be preferred over a multiple-fraction approach for patient convenience.

To further improve the 1-year TCP above $73 \%$, the normal tissue constraint $V_{20 G y}=20$ $\mathrm{cm}^{3}$ needs to be relaxed, but this may result in an unacceptably high risk of radionecrosis. Alternatively, an approach with more than five fractions could be investigated if this approach increases the therapeutic ratio. The calculated TCPs are based on the model of Wiggenraad based on single-fraction SRS data for BM, and the same model was used to calculate the TCP with five fraction SRS.[4] However, a fractionated approach may be beneficial for re-oxygenation of the tumor, which may increase its radiosensitivity.[22] Therefore, the calculated TCP of $73 \%$ in very large BM (e.g., with a diameter of $4 \mathrm{~cm}$ ) may be an underestimation of a clinically observed TCP using five fraction IDP. The current TCP model includes only prescription dose as a prognostic variable, but further extension of this model with other factors such as BM volume and possibly imaging characteristics reflecting hypoxia may further improve its accuracy. However, the influence of tumor size is difficult to quantify because in many series, lower doses are prescribed for larger BM or prescribed doses vary widely. Furthermore, the model needs to be externally validated and calibrated in other patient cohorts treated with SRS for BM. Dose-volume thresholds for an acceptably low risk of radionecrosis for schemes other than single-fraction and five-fraction SRS do not exist in literature. Therefore, only single- and five fraction schedules were used in the current study.

To exploit the full potential of IDP in SRS, it is necessary to minimize the GTV-PTV margin and to optimize the beam arrangements by increasing the setup accuracy ( 6 degrees of freedom couch and a robust frameless mask).[23-24] Taking into account that the risk of radionecrosis increases rapidly above $10 \%$ as the $V_{12 G y}$ exceeds $10 \mathrm{~cm}^{3}$ for singlefraction SRS, it is clinically highly relevant to strive for a smaller GTV-PTV margin and to explore the feasibility of dose delivery with non-coplanar beam arrangements.[15] This is supported by a recently published randomized trial demonstrating that a decrease of the GTV-PTV margin from 3 to $1 \mathrm{~mm}$ does not decrease the local control probability for LINAC-based SRS.[18] As this study showed that there was a significantly larger $V_{12 G y}$ in the $3 \mathrm{~mm}$ GTV-PTV margin group, the authors stated that a $1 \mathrm{~mm}$ GTV-PTV margin 
should be used to avoid any unnecessary risk of radionecrosis and serious risk of neurologic morbidity.

A limitation of our research is the lack of clinical validation of the models to predict TCP and NTCP. The TCP model is based on retrospective clinical studies.[4] Prospective clinical validation is needed for the NTCP model by using a $V_{12 G y}=10 \mathrm{~cm}^{3}$ constraint for single-fraction IDP and $a V_{20 G y}=20 \mathrm{~cm}^{3}$ constraint for five-fraction IDP. $[3,15,21]$

In conclusion, with five-fraction IDP, non-coplanar beams and a $1 \mathrm{~mm}$ set-up margin, the predicted 1- year TCP was safely increased from $42 \%$ to $68 \%$ in very large BM compared to single-fraction 15 Gy SRS. For the treatment to be more effective either relaxation of the normal tissue constraint $V_{20 G y}=20 \mathrm{~cm}^{3}$ or a fractionated approach with more than five fractions is needed. A prospective clinical trial is needed to validate the predicted effectiveness in terms of 1-year TCP and to assess the safety of IDP regarding NTCP.

\section{APPENDIX}

Fitted TCP model for 12-month local rate

In Wiggenraad et al. (2011), a dose-response relation between the biologically effective dose of the linear-quadratic-cubic model using an $\alpha / \beta$ of 12 Gy (BED12) and the 12month local control rates were constructed by eye fitting. Herein we obtained a statistical better fit by first digitizing the data points from Wiggenraad's figure (4, Figure 1) using GraphClick software (version 3.0.2, Arizona Software) and subsequently fitting a logistic dose-response model by the maximum likelihood estimation: where D = BED12, D50 is the BED12 at $50 \%$ local control, $\gamma 50$ is the normalized slope at D50, and TCPmax is the asymptotic local control rate for large $D$. The fitted dose-response graph is shown in Figure 6. The model parameters obtained are D50 = 28.97 Gy (95\% Cl: 24.80-33.14 Gy), ү50 = 1.41 (95\% Cl: 0.40-2.87), and TCPmax $=86.86 \%(95 \% \mathrm{Cl}: 70.62-103.10 \%)$. 
Individualized isotoxic dose prescription for stereotactic radiotherapy

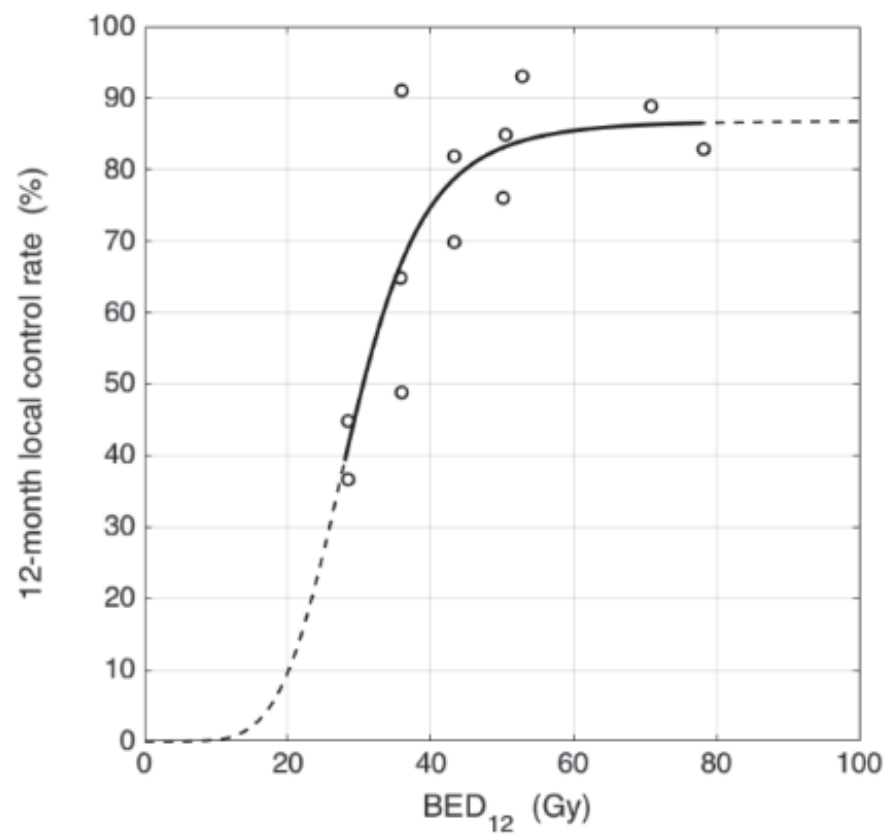

Figure 6. A fitted dose-response curve based on data from Wiggenraad et al.[4] 


\section{REFERENCES}

[1] Bohoudi O, Bruynzeel AM, Lagerwaard FJ, Cuijpers JP, Slotman BJ, Palacios MA.. Isotoxic radiosurgery planning for brain metastases. Radiother Oncol. 2016; pii: S0167-8140(16)31087-8.

[2] Zindler JD, Rodrigues G, Haasbeek CJ, et al. The clinical utility of prognostic scoring systems in patients with brain metastases treated with radiosurgery. Radiother Oncol. 2013;106:370-74.

[3] Shaw E, Scott C, Souhami L, et al. Single dose radiosurgical treatment of recurrent previously irradiated primary brain tumors and brain metastases: final report of RTOG protocol 90-05. Int J Radiat Oncol Biol Phys. 2000;47:291-98.

[4] Wiggenraad R, Verbeek-de Kanter A, Kal HB, Taphoorn M, Visser T, Struikmans H. Dose-effect relation in stereotactic radiotherapy for brain metastases: A systematic review. Radiother Oncol. 2011;98:292-97.

[5] ICRU Report 83: Prescribing, recording and reporting intensity-modulated photonbeam therapy (IMRT). J ICRU. 2010;10:1093.

[6] https://www.clinicaltrials.gov/ct2/results?term=large+brain+metastases\&Search=Search

[7] Hoffmann AL, Troost EG, Huizenga H, Kaanders JH, Bussink J. individualized dose prescription for hypofractionation in advanced non-small-cell lung cancer radiotherapy: an in silico trial. Int J Radiat Oncol Biol Phys. 2012;83:1596-02.

[8] Beasley M, Driver D, Dobbs HJ. Complications of radiotherapy: improving the therapeutic index. Cancer Imaging. 2005;5:78-84.

[9] van Elmpt W, Öllers $M$, Velders $M$, et al. Transition from a simple to a more advanced dose calculation algorithm for radiotherapy of non-small 5 cell lung cancer (NSCLC): implications for clinical implementation in an individualized dose-escalation protocol. Radiother Oncol. 2008;88:326-34.

[10] De Ruysscher D, van Baardwijk A, Steevens J, et al. Individualised isotoxic accelerated radiotherapy and chemotherapy are associated with improved long-term survival of patients with stage III NSCLC: a prospective population-based study. Radiother Oncol. 2012;102:228-33.

[11] Hoffmann AL, Troost EG, Huizenga H, Kaanders JH, Bussink J. individualized dose prescription for hypofractionation in advanced non-small-cell lung cancer radiotherapy: an in silico trial. Int J Radiat Oncol Biol Phys. 2012;83:1596-02.

[12] Baardwijk A, Wanders S, Boersma L, et al. Mature results of an individualized radiation dose prescription study based on normal tissue constraints in stages I to III non-small-cell lung cancer. J Clin Oncol. 2010;28:1380-86.

[13] Baardwijk A, Bosmans G, Bentzen SM, et al: Radiation dose prescription for nonsmall- cell lung cancer according to normal tissue dose constraints: An in silico clinical trial. Int J Radiat Oncol Biol Phys 2008;71:1103-10.

[14] Zindler JD, Thomas CR Jr, Hahn SM, Hoffmann AL, Troost EG, Lambin P. Increasing the Therapeutic Ratio of Stereotactic Ablative Radiotherapy by Individualized Isotoxic Dose Prescription. J Natl Cancer Inst. 2015;108:djv305.

[15] Marks LB, Yorke ED, Jackson A, et al. Use of normal tissue complication probability models in the clinic. Int J Radiat Oncol Biol Phys. 2010;76:S10-19.

[16] Lo SS, Sahgal A, Chang EL, et al. Serious complications associated with stereotactic ablative radiotherapy and strategies to mitigate the risk. Clin Oncol (R Coll Radiol). 2013;25:378-87.

[17] Timmerman RD. An overview of hypofractionation and introduction to this issue of seminars in radiation oncology. Semin Radiat Oncol. 2008;18:215-22.

[18] Kirkpatrick JP, Wang Z, Sampson JH, et al. Defining the optimal planning target volume in image-guided stereotactic radiosurgery of brain metastases: results of a randomized trial. Int J Radiat Oncol Biol Phys. 2015;91:100-08.

[19] Fokas E, Henzel M, Surber G, Kleinert G, Hamm K, Engenhart-Cabillic R. Stereotactic radiosurgery and fractionated Stereotactic Radiotherapy: comparison of efficacy and toxicity in 260 patients with brain metastases. J Neurooncol 2012;109:91-98 
[20] Wegner RE, Leeman JE, Kabolizadeh P et al (2013) Fractionated Stereotactic Radiosurgery for Large Brain Metastases. Am J Clin Oncol. 2015;38:135-39.

[21] Ernst-Stecken A, Ganslandt O, Lambrecht U, Sauer R, Grabenbauer G. Phase II trial of hypofractionated stereotactic radiotherapy for brain metastases: results and toxicity. Radiother Oncol. 2006;81:18-24.

[22] Nahum AE. The radiobiology of hypofractionation. Clin Oncol (R Coll Radiol). 2015 May;27(5):260-9.

[23] Seung SK, Larson DA, Galvin JM, et al. American College of Radiology (ACR) and American Society for Radiation Oncology (ASTRO) Practice Guideline for the Performance of Stereotactic Radiosurgery (SRT). Am J Clin Oncol. 2013;36:310-15.

[24] Seravalli E, van Haaren PM, van der Toorn PP, Hurkmans CW. A comprehensive evaluation of treatment accuracy, including end-to-end tests and clinical data, applied to intracranial stereotactic radiotherapy. Radiother Oncol. 2015;116:131-38. 

Chapter

General discussion and future perspectives 

The aim of the research in this thesis is to improve patient selection and outcome with stereotactic radiosurgery (SRS) for brain metastases (BM). The main hypotheses of this thesis are:

1) Individualized prognostic models predict survival and the occurrence of distant brain recurrences after SRS alone for BM more accurately than currently available prognostic models

2) A multicenter randomized phase III trial can be initiated to investigate whether SRS alone provides a better quality of life than WBRT in patients with 4 to 10 BM

3) The 1-year tumor control probability of SRS for large BM can be improved by isotoxic dose prescription (IDP) in a modelling study

The first hypothesis was tested to optimize and individualize the information for patients to facilitate the decision-making process for patients and caretakers. Patients make decisions based on the advice of their physician, but also based on personal, emotional, social, and psychological factors. The final choice of the patient for any treatment may differ from the advice of the physician because of the personal preferences of the patient.[1] The physician informs the patient about the standard of care according to guidelines, but also about individualized perspectives per treatment regarding survival, chances of disease control, and toxicity. The patient then makes the final decision about treatment options, a process called shared decision-making. Prognostic models may help the physician and patient to estimate the outcome per treatment modality. In this thesis, prognostic models for stereotactic radiosurgery (SRS) in the treatment for patients with brain metastases (BM) were developed to more accurately predict outcome than existing models to better facilitate the shared decision-making process.

To achieve improvement in giving personalized advice to patients with $\mathrm{BM}$, in this thesis, the first focus was on existing prognostic classification systems and investigated potential advancements in these models (chapter 2).[2] The major limitation of currently available prognostic models is the lack of individualized outcome prediction, and only a group-based prediction by categorizing patients into favorable, intermediate, and unfavorable prognostic groups can be derived. In addition, there appears to be an unbalanced patient distribution over the prognostic classes: the proportion of patients in the intermediate prognostic group(s) far outweigh those in the unfavorable and favorable prognostic group(s). Having an unfavorable or favorable prognosis is of specific relevance to the patient with respect to the decision to undergo a treatment, contrary to having an intermediate prognosis. The clinical characteristics of patients with BM differ enormously, even within prognostic classes; for example, a young female with HER2/neu positive breast cancer and small BM can be in the same class as a relatively old male patient with a larger, more central BM from undifferentiated non-small cell lung cancer. The expected outcomes after BM treatment of these 2 examples differ with respect to survival, probability for long-term survival, systemic treatment options, 
and toxicity of treatment. Therefore, there is a need for models incorporating all potential relevant factors for the prediction of outcomes for clinical endpoints including patient, tumor, and treatment characteristics. The current available models are not sophisticated enough to allow accurate and individualized patient information per tumor type and treatment.

The primary goal of SRS is to control BM and maintenance of neurologic function, which is also valuable in a palliative setting (chapters $3 \& 7$ ). Paralysis, epilepsy, and neurocognitive damage by progressive BM have an important negative impact on quality of life and survival and may be prevented or postponed by SRS.[4] However, personal considerations of the patient and their caretakers on costs and benefits of treatment may differ from the perspectives of clinicians. A patient may choose best supportive care over SRS if the anticipated life expectancy is short and can be measured in weeks.[3] Although the definition of "short life expectancy" or "early death" can be debated, for our analysis, a subjective period of 3 months was chosen. It can be argued that having a significant risk of dying within 3 months, the investments for both patients and society (costs) outweigh the efforts of SRS; patients need several outpatient clinical visits, fabricating a customized immobilization mask, and generating a planning CT scan, a planning MR scan, and the SRS treatment delivery itself. In addition, there is also a risk of side effects that cannot be ignored. Although the side effects of SRS are usually modest and temporary, including an increase in fatigue and (pre-existing) neurologic symptoms, these may be unacceptable in case of a short expected life span. Obviously, it is essential that the prediction of "short life expectancy" is accurate in order not to inappropriately withhold the beneficial effects of SRS. Chapter 6 shows that our developed individualized prognostic model predicts "early death" after SRS from BM of non-small cell lung cancer (NSCLC) more accurately than current available models, such as the recursive partitioning analysis (RPA). The area under the curve for the prediction of early death with recursive operating characteristics $(R O C)$ analysis was 0.70 vs $0.55(P<0.01)$ for the nomogram and the RPA, respectively, in the external validation cohort.[5]

Another related issue with clinical relevance is an estimation of the likelihood of longterm survival. Again, this definition remains arbitrarily, but survival for longer than 1 year after a diagnosis of BM would best reflect the label "long term." Defining the likelihood of long-term survival is of importance, not only for patient information, but also for determining the appropriateness of more aggressive (or costly) forms of treatment for extracranial cancer sites, such as surgery, immunotherapy, or other combined treatment modalities. The goal of aggressive extracranial treatment in cerebral metastasized patients is to control the extracranial disease and achieve long-term survival, preferably over several years.[6] However, because only a small proportion of patients with BM will survive over several years (5-10\% depending on patient selection), ${ }^{2}$ it is important to correctly identify these patients. As part of this thesis, an extensive database was used of patients with BM of NSCLC, the most frequent origin of BM, treated 
with SRS as a single modality to refine current prognostic classification systems and to develop nomograms for the individualized prediction of "early death" and "long-term survival," respectively. These nomograms were published, but for wider diffusion into clinical practice, these models were uploaded on www.predictcancer.org. Using a relatively straightforward input of a limited number of variables such as gender, age, performance status, presence or absence of extracranial metastases, and volume of the largest BM, a fast estimation of the risk of "early death" and likelihood of "long-term survival" after SRS is immediately provided. By presenting accurate and individualized outcome information to the patient it is likely that this tool will be informative for both clinicians and patients and may provide further guidance for shared decision making.

SRS is increasingly used as an alternative to WBRT, mostly to prevent subacute and delayed adverse sequelae such as neurocognitive deficits resulting from irradiating normal brain tissue. However, being a form of high-precision local treatment, the downside of using SRS as a single modality is that occult micrometastases are left untreated (chapter 7). As a consequence, this approach results in a significant risk of finding new BM during follow-up, so-called distant brain recurrences (DBR) in $39-70 \%$ of patients within 1 year (chapter 5).[7,8] These new metastases can be the result of the outgrowth of radiologically occult metastatic deposits or reseeding from extracranial active disease. An indication that the latter also plays a role can be obtained by the observation that if patients survive for several years after SRS, the vast majority will suffer from DBR (cumulative incidence of $86 \%$ at 2 years with Kaplan Meyer analysis). The issue of development of new BM following SRS has consequences, both for followup strategies and for salvage therapy with SRS, WBRT, systemic therapy, or occasionally even surgery. In general, most Dutch centers advice 3-monthly follow-up MRI scans after SRS for BM. Therefore, SRS as a single modality is the standard treatment for patients with a maximum of $3 \mathrm{BM}$. As part of this thesis, the incidence and characteristics of these new lesions were investigated after SRS alone and a nomogram was developed for individualized prediction of the risk for DBR (chapter 4). For this prediction model, the number of initially treated BM, age, the volume of largest BM, and WHO performance status were important.[9] For clinical use, this calculation model to predict DBR within 1 year after SRS for BM is also available on www.predictcancer.org. It should be stressed, however, that this model is based on clinical data in which the vast majority of patients were treated for 1 or $2 \mathrm{BM}$ and therefore is not validated in patients treated with SRS alone for more than 3 lesions. With this restriction in mind, this tool can be used to discuss the need and the frequency of follow-up MRIs with patients. Independent of this calculation, scheduled MRI follow-up will also be determined by the overall disease progression status and performance of the patient.

The individualized models, and especially the nomograms, that were developed in this thesis for patients with SRS of BM are a major improvement compared to traditional group-based prognostic models in the support of shared decision-making. A methodol- 
ogy for the development of individualized models was illustrated. These developed models are still relatively simple and based on small patient cohorts. More complex models are needed for more clinical endpoints, for more primary tumor types, and more treatment options to further individualize the treatment of BM patients. In addition, web-based shared decision tools need to be developed incorporating all relevant treatment options for all potential clinical settings. Therefore, it is likely that these models were just the first steps for the support of real individualization of the treatment of patients with BM, which is appropriate in the era of personalized medicine.

The second hypothesis is defined to test whether it was possible do a prospective randomized phase III trial to potentially change clinical practice for patients with more than $3 \mathrm{BM}$. According to guidelines in the Netherlands, SRS is advised for patients with a maximum of 3 lesions. Additional WBRT after SRS as a single modality decreases the risk of DBR but does not provide a survival benefit. Moreover, additional WBRT to SRS results in poorer quality of life than SRS only because of the side effects of WBRT (chapters 7 \& 9). For those with 4 or more BM, WBRT is the recommended strategy. Background for this advice is the lack of evidence that SRS has better outcomes than WBRT for multiple lesions, the notion that these patients had particularly poor prognosis, and that treatment for multiple lesions with SRS would be a time-consuming and costly palliative treatment, taking almost an hour of treatment per BM.[10] New evidence has recently become available for patients treated with SRS alone for multiple BM, which may result in a paradigm shift. In a large study, selected patients with 2-4 BM had comparable survival as patients with 5-10 BM.[11] In a sequential report, the same group showed that patients with 2-9 BM had the same survival as patients with 10 or more BM.[12] These studies raise the question of whether SRS alone should be reserved only for patients with 2-3 BM, or that patients having 4 or more BM may also benefit from this treatment. Recent technological advances enable accurate and precise treatment with SRS of multiple BM within several minutes. Also, more effective systemic treatments have become available that control BM and thereby improve the prognosis of the patients with multiple BM. With the recent technological improvements allowing SRS in multiple BM, it is of interest if patients with more than $3 \mathrm{BM}$ are better treated with SRS than with WBRT with respect to quality of life and survival probability. The potential advantages of SRS over WBRT are a higher probability of local tumor control and avoidance of some of the side effects of WBRT, such as hair loss, fatigue, and neurocognitive damage. $[13,14]$ The potential advantage of WBRT over SRS is the treatment of subclinical micrometastases in the brain, which, in regard of the frequent occurrence of DBR after SRS alone, will be present in the vast majority of patients. If these micrometastases progress rapidly, they may cause neurologic symptoms during follow-up after SRS. Also, the risk of radionecrosis (RN) is avoided with WBRT, in contrast to SRS. To gain more insight on this issue, a multicenter randomized trial was successfully initiated in the Netherlands that is currently ongoing (chapter 8).[15] Although some physi- 
cians already assume that SRS alone is a better treatment than WBRT for patients with more than $3 \mathrm{BM}$, high-level clinical evidence is absent. Selection bias is a problem in the current available literature and therefore a randomized trial is needed. It is our hope that the new standard of care for patients with multiple BM can be based on this trial and other prospective randomized trials that are being initiated in the United States.[16]

Randomized phase III trials are not conflicting and are very useful for the process of shared decision making and personalized medicine. Data gathered in randomized trials are a solid basis to quantify a potential benefit in outcome between treatment options. In situations where randomized trials are lacking, such as in patients with more than 3 $\mathrm{BM}$, it is possible to estimate outcome of individual treatment options, but these estimations remain hampered by selection bias and physician preferences. Although the costs and efforts of conducting a randomized trial are significant, this effort is certainly worth a try with the goal to provide reliable outcome information for the patient. Therefore, randomized trials are still a very good option to determine whether a change in clinical practice is justified, although the administrative burden, the process of design, and the efforts to stimulate accrual are significant in an era with limited health care budgets and limited time for research during busy daily clinical practice.

The third hypothesis is defined to test whether a new form of SRS dose prescription is useful to potentially improve clinical outcome in patients with large BM. Patients with large BM are often inoperable, because of a poor life expectancy or a high-risk location of the BM. Because of concerns regarding the risk of RN in larger lesions, the SRS dose is generally lower than in smaller lesions. However, the results of single fraction SRS with a dose of $15 \mathrm{~Gy}$ are suboptimal.[12] A local recurrence of an inoperable BM may result in neurological damage and dysfunction followed by death. The probability of control 1 year after SRS of the BM is approximately $40 \%$ with a single fraction of 15 Gy and despite lowering the dose often there remains a relatively high risk of complications, named RN.[17] A potential solution for this clinical dilemma is a relatively new form of SRS dose prescription, isotoxic dose prescription (IDP, chapter 10).[18] In a modelling study, fractionated IDP enabled a safe increase in the predicted probability of control of BM $4 \mathrm{~cm}$ in diameter to +/- 70\% while simultaneously maintaining an acceptable risk of RN (chapter 11).[19] This was achieved by respecting the tolerance dose of the healthy brain tissue, moderate fractionation up to 5 fractions, and simultaneous dose escalation in the BM to the technically highest achievable dose.

An important technical aspect for the risk of RN is the GTV-PTV margin. This is an additional margin contoured around the BM of 1 up to $3 \mathrm{~mm}$ of nearby healthy brain tissue that is also irradiated to the prescribed dose to account for setup and other uncertainties. The GTV-PTV margin is determined per institution based on an in silico model and is often to be advised to be at least $1 \mathrm{~mm}$.[20] However, during clinical validation with 
SRS for BM this in silico model appeared to not be in line with clinical results. In a randomized trial, a GTV-PTV margin of $1 \mathrm{~mm}$ resulted in the same local control with SRS for BM as a GTV-PTV margin of $3 \mathrm{~mm}$ despite usage of non-coplanar beams.[21] Therefore, there is a need to use other models and to consider the clinical disadvantages for the patient of GTV-PTV margins larger than $1 \mathrm{~mm}$. In the study, the patients in which a GTVPTV margin of $3 \mathrm{~mm}$ was applied were exposed to a higher RN risk than the patients with a $1 \mathrm{~mm}$ GTV-PTV margin. Therefore, the authors concluded that a $1 \mathrm{~mm}$ GTV-PTV margin is preferable above a $3 \mathrm{~mm}$ GTV-PTV margin. In this choice the clinical outcome, e.g. risk for $\mathrm{RN}$ and equal local control, are preferred above potential physical uncertainties. The equal local control in the $1 \mathrm{~mm}$ GTV-PTV margin cohort can be explained by tumor cell sterilization outside the PTV of the high dose penumbra. This is a paradigm shift, because in daily clinical practice often physical uncertainties dominate decision making with respect to GTV-PTV margin choice per institution. To minimize the risk of RN with SRS for BM and by considering the sterilization of tumor cells outside the PTV, it is defendable and advisable that radiation oncologists minimize or even avoid a GTV-PTV margin during SRS for BM. This is especially relevant in the setting of IDP. In our modelling study (chapter 11), avoidance of a GTV-PTV margin allowed for an optimal therapeutic ratio (ratio tumor control probability: risk for RN) in the setting of both IDP and standard SRS dose prescription.[19] The promising results of 5 fraction IDP in large BM need further clinical validation, especially in patients with large inoperable BM (for example, PTVs larger than $10 \mathrm{~cm}^{3}$ ). A high local control probability of BM is relevant for patients with a high probability of long term survival.

Based on the expected gain in clinical outcome, IDP will enable further individualization and improvement of the treatment of patients with BM. Physicians are currently deciding about the prescribed dose and thereby the probability of tumor control without involving the patient. This is undesirable in the era of personalized medicine. For certain patients, it is more desirable to visit the clinic only once and have a $40 \%$ tumor control probability after 1 year: for example, for an old man with undifferentiated NSCLC without systemic treatment options, a life expectancy of 5 months, and a strictly palliative SRS treatment a very short treatment duration is desirable to avoid unnecessary aggravation of the patient. For other patients, long-term tumor control and a high probability of permanent ablation of the BM is desirable, such as a young female with breast cancer and several systemic treatment options with a life expectancy of several years. For this patient, the number of fractions may be less relevant if it results in an improved clinical outcome. In current daily clinical practice, both patients will receive the same standard dose and both the physician and patient are often unaware of the consequences for tumor control probability and risk of RN. Applying IDP will force the physician to quantify tumor control probability to the patient and facilitate the process of shared decision making. Moreover, from a technical perspective, it will become clear that GTV-PTV margins will directly affect the therapeutic ratio. This will stimulate both 
the radiation oncologist and the clinical physicist to optimize the accuracy of the SRS treatment to minimize or even avoid GTV-PTV margins for a minimization of the risk of RN and optimization of the tumor control probability as IDP is applied. Although our study is just a modelling study and needs further clinical validation, showing the potential of IDP will hopefully result in widespread application of IDP with SRS for BM with shared decision making.

The limitations of the studies to the prognostic models are their retrospective design. These studies best reflect the outcome of patients treated in daily clinical practice and the data were relatively complete with only very limited missing data. Models based on cohorts of patients treated in randomized trials have the advantage that the data are more structured but may reflect better outcome than achieved in clinical practice outside the setting of a prospective trial. Another limitation was the relatively small sample size of the studied patient cohort and the relatively limited number of patients and treatment characteristics that were studied. Also, the prognosis of patients treated at present may be slightly better, because recently more systemic treatment options have become available, which also may control BM and improve outcome. Almost all patients in our studies received SRS as a first line of treatment and at present there is a trend to use SRS as a salvage treatment after the failure of primary systemic treatment of BM.

The limitation of the randomized trial that was initiated is that a small minority of Dutch hospitals did not join the study. Hospitals that use Gamma Knife are lacking in our study and are encouraged to join. Another limitation is that all primary tumor types are allowed in the study. Ideally trials are designed per tumor type, but these trials will be hampered by lack of accrual. Moreover, each tumor type, such as breast cancer or nonsmall cell lung cancer, comprised of very heterogeneous tumor subtypes, such as HER2/neu- or hormone receptor-positive and -negative breast cancer. It will not be feasible to do randomized trials for all these subtypes of breast cancer. For our randomized trial, the primary tumor type and the subtypes may have very limited influence on the outcome of the trial because the primary endpoint is quality of life, not survival. The expectation is that the treatment type (WBRT or SRS) will be responsible for the quality of life after treatment and not the (sub)type of primary tumor.

The IDP study is limited by the fact that it is just a modelling study and clinical data to show the benefit of IDP are currently lacking. These data will be provided in the near future. 


\section{FUTURE PERSPECTIVES}

\section{Individualised treatment outcome modelling for shared decision making}

Individualized prognostic models for patients with BM need to be developed and refined per treatment option (for example, SRS, WBRT, systemic therapy, or best supportive care) and per tumor type. Optimization of the accuracy of these models can be accomplished by incorporating more tumor characteristics, patient characteristics, imaging characteristics, and biomarkers.[22,23] New prognostic models can be evaluated by the TRIPOD guidelines and software used to generate these models needs to be certified.[24] The patient information is stored worldwide in individual hospitals and can be extracted with a distributed learning approach enabling avoidance of harm of the privacy of the patient. MAASTRO Clinic and MUmc+ are cooperating with several centers worldwide with the goal of developing accurate multifactorial prognostic and even predictive models. The eventual goal is so-called shared decision-making in which both the patient and the physician discuss the predicted outcomes per treatment, allowing the patient to take a more informed choice of treatment options.[25-28]

\section{A multicenter phase III trial to compare SRS with WBRT in patients with more than $3 B M$}

The goal in the next years will be to finish the trial in 230 patients within a limited time span, preferably 2 years. At September 2017, 9 Dutch centers were open and patients from several hospitals were randomized. The goal for 2017 is to open another 4 Dutch centers (13 centers in total in the Netherlands) and discussion is ongoing to open the study in centers abroad, such as Belgium, the United Kingdom, Italy, and Germany. Another development is international cooperation to optimize the quality of SRS for BM. Three other randomized trials with comparable primary endpoints are being initiated in the United States and Canada. There is contact between the study coordinators and medical physicists to synchronize the quality assurance of the SRS treatment technique. If all trials succeed, this will enable a meta-analysis of all data gathered in the 4 randomized trials because of minimal variation in SRS treatment quality and thereby outcome. The meta-analysis will provide high-quality evidence for the potential additional value of SRS over WBRT in patients with more than 3 BM. This will serve as a basis for shared decision tools for patients with BM.

Isotoxic dose prescription to individualize SRS and improve outcome in large BM

IDP will likely replace standard SRS dose prescription and be the basis for the individualized application of SRS for patients with BM. Currently, physicians prescribe standard 
SRS doses and patients are not informed about tumor control probability (TCP) and normal tissue complication probability (NTCP). In the era of personalized medicine, IDP will provide a basis for shared decision making. By applying IDP, the physician will discuss with the patient the TCP and NTCP, what is achievable if the treatment schedule is extended with moderate fractionation. The patient will then decide about the TCP/NTCP and the number of fractions. Moreover, IDP will stimulate radiation oncologists and clinical physicists to optimize the precision and quality of the SRS treatment delivery to minimize GTV-PTV margins and achieve the highest therapeutic ratio with SRS. In the treatment planning system, not only dose should be visualized, but also TCP and NTCP. At the outpatient clinic, the radiation oncologist can show the patient the effect of the application of IDP on TCP and NTCP instead of standard SRS dose prescription and the effect of moderate fractionation with SRS. IDP will also enable a safe increase of the therapeutic ratio, especially in large inoperable BM as was shown in our modelling study.[19] With solid outcome registration, the observed outcome will be compared to the expected outcome. By applying this model-based approach, a randomized trial is not needed to replace standard SRS dose prescription with IDP in daily clinical practice. In future trials incorporating IDP, minimal TCP and maximum NTCP will be defined instead of standard radiotherapy doses.

\section{Combining SRS with immunotherapy}

This thesis describes the outcome of patients with BM treated with SRS as single modality, mostly in the first line of BM treatment. At present, more effective systemic agents are available that have the potential to control BM. Systemic therapies are increasingly being used in the first line of treatment, especially for asymptomatic small BM. SRS will be reserved if the BM progress under systemic therapy and SRS will be part or a tool in a multimodality treatment of intracranial and extracranial treatment over several months or years. A very interesting potential improvement of outcome is the combination of SRS or conventional fractionated radiotherapy with immunotherapy. The goal is that the irradiated BM serve as a vaccine to treat microscopic disease in the brain and elsewhere. The patient's immune system is enhanced with immunotherapy to attack microscopic cancer cells by annihilating checkpoint inhibitors and/or directly stimulating the immune system with immunocytokines. The hope is that this strategy provides a survival benefit compared to systemic or radiotherapy treatment only.[29-31] 


\section{REFERENCES}

[1] Reyna VF, Nelson WL, Han PK, Pignone MP. Decision making and cancer. Am Psychol. 2015 FebMar;70(2):105-18.

[2] Zindler JD, Rodrigues G, Haasbeek CJ, Haan PF, Meijer OW, Slotman BJ, Lagerwaard FJ. The clinical utility of prognostic scoring systems in patients with brain metastases treated with radiosurgery. Radiother Oncol 2013 Mar;106(3):370-4.

[3] Hendriks LE, Troost EG, Steward A, Bootsma GP, De Jaeger K, van den Borne BE, Dingemans AM. Patient selection for whole brain radiotherapy (WBRT) in a large lung cancer cohort: Impact of a new Dutch guideline on brain metastases. Acta Oncol. 2014 Jul;53(7):945-51.

[4] Jung H, Sinnarajah A, Enns B, Voroney JP, Murray A, Pelletier G, Wu JS. Managing brain metastases patients with and without radiotherapy: initial lessons from a team-based consult service through a multidisciplinary integrated palliative oncology clinic. Support Care Cancer. 2013 Dec;21(12):3379-86.

[5] Zindler JD, Jochems A, Lagerwaard FJ, Beumer R, Troost EG, Eekers DB, Compter I, Van der Toorn PP, Essers M, Oei B, Hurkmans CW, Bruynzeel AM, Bosmans G, Swinnen A, Leijenaar RT; Lambin P. Individualized early death and long-term survival prediction after stereotactic radiosurgery for brain metastases of non-small cell lung cancer: two externally validated nomograms. Radiother Oncol. 2017 May;123(2):189-194.

[6] Lind JS, Lagerwaard FJ, Smit EF, Postmus PE, Slotman BJ, Senan S. Time for reappraisal of extracranial treatment options? Synchronous brain metastases from nonsmall cell lung cancer. Cancer. 2011 Feb 1;117(3):597-605.

[7] Zindler JD, Slotman BJ, Lagerwaard FJ. Patterns of distant brain recurrences after radiosurgery alone for newly diagnosed brain metastases: implications for salvage therapy. Radiother Oncol. 2014 Aug;112(2):212-6.

[8] Ayala-Peacock DN, Peiffer AM, Lucas JT, Isom S, Kuremsky JG, Urbanic JJ, Bourland JD, Laxton AW, Tatter $\mathrm{SB}$, Shaw EG, Chan MD. A nomogram for predicting distant brain failure in patients treated with gamma knife stereotactic radiosurgery without whole brain radiotherapy. Neuro Oncol. 2014 Sep;16(9):1283-8

[9] Rodrigues G, Warner A, Zindler JD, Slotman BJ, Lagerwaard FJ. A Clinical Nomogram and Recursive Partitioning Analysis to Determine the Risk of Regional Failure after Radiosurgery Alone for Brain Metastases Radiotherapy and Oncology. Radiother Oncol. 2014 Apr;111(1):52-8.

[10] Rodrigues G, Zindler J, Warner A, Bauman G, Senan S, Lagerwaard F. Propensity-score matched pair comparison of whole brain with simultaneous in-field boost radiotherapy and stereotactic radiosurgery. Radiother Oncol. 2013 Feb;106(2):206-9.

[11] Yamamoto M, Serizawa T, Shuto T, Akabane A, Higuchi Y, Kawagishi J, Yamanaka K, Sato Y, Jokura H, Yomo S, Nagano O, Kenai H, Moriki A, Suzuki S, Kida Y, Iwai Y, Hayashi M, Onishi H, Gondo M, Sato M, Akimitsu T, Kubo K, Kikuchi Y, Shibasaki T, Goto T, Takanashi M, Mori Y, Takakura K, Saeki N, Kunieda E, Aoyama H, Momoshima S, Tsuchiya K. Stereotactic radiosurgery for patients with multiple brain metastases (JLGK0901): a multi-institutional prospective observational study. Lancet Oncol. 2014 Apr;15(4):387-95.

[12] Yamamoto M, Kawabe T, Sato Y, Higuchi Y, Nariai T, Watanabe S, Kasuya H. Stereotactic radiosurgery for patients with multiple brain metastases: a case-matched study comparing treatment results for patients with 2-9 versus 10 or more tumors. J Neurosurg. 2014 Dec;121 Suppl:16-25.

[13] Zindler JD, Gijtenbeek JMM, Lagerwaard FJ. Postoperative management after resection of a single brain metastasis: whole brain radiotherapy, local radiotherapy, or 'wait and scan'? Dutch Journal of Oncology. Dutch Journal of Oncology 2013;10(8):318-23.

[14] Rodrigues G, Zindler JD, Warner A, Lagerwaard FJ. Recursive Partitioning Analysis for the Prediction of Stereotactic Radiosurgery Brain Metastases Lesion Control. The Oncologist 2013;18(3):330-5.

[15] Zindler JD, Bruynzeel AME, Eekers DBP, Hurkmans CW, Swinnen A, Lambin P. Whole brain radiotherapy versus Stereotactic Radiosurgery for 4 - 10 brain metastases: a phase III randomized multicenter trial study protocol submitted. 
[16] www.clinicaltrial.gov NCT01592968

[17] Wiggenraad R, Verbeek-de Kanter A, Kal HB, Taphoorn M, Vissers T, Struikmans H. Dose-effect relation in stereotactic radiotherapy for brain metastases. A systematic review. Radiother Oncol. 2011 Mar;98(3):292-7.

[18] Zindler JD, Thomas CR Jr, Hahn SM, Hoffmann AL, Troost EG, Lambin P. Increasing the Therapeutic Ratio of Stereotactic Ablative Radiotherapy by Individualized Isotoxic Dose Prescription. J Natl Cancer Inst. 2015 Oct 16;108(2).

[19] Zindler JD, Schiffelers J, Lambin P, Hoffmann A. Individualized isotoxic dose prescription for stereotactic radiotherapy in large brain metastases: an in-silico study - submitted.

[20] Seravalli E, van Haaren PM, van der Toorn PP, Hurkmans CW. A comprehensive evaluation of treatment accuracy, including end-to-end tests and clinical data, applied to intracranial stereotactic radiotherapy. Radiother Oncol. 2015 Jul;116(1):131-8

[21] Kirkpatrick JP, Wang Z, Sampson JH, McSherry F, Herndon JE 2nd, Allen KJ, Duffy E, Hoang JK, Chang Z, Yoo DS, Kelsey CR, Yin FF. Defining the optimal planning target volume in image-guided stereotactic radiosurgery of brain metastases: results of a randomized trial. Int J Radiat Oncol Biol Phys. 2015 Jan 1;91(1):100-8.

[22] Aerts HJ, Velazquez ER, Leijenaar RT, Parmar C, Grossmann P, Carvalho S, Bussink J, Monshouwer R, Haibe-Kains B, Rietveld D, Hoebers F, Rietbergen MM, Leemans CR, Dekker A, Quackenbush J, Gillies RJ, Lambin P. Decoding tumour phenotype by noninvasive imaging using a quantitative radiomics approach. Nat Commun. 2014 Jun 3;5:4006.

[23] De Ruysscher D, Defraene G, Ramaekers BL, Lambin P, Briers E, Stobart H, Ward T, Bentzen SM, Van Staa T, Azria D, Rosenstein B, Kerns S, West C. Optimal design and patient selection for interventional trials using radiogenomic biomarkers: A REQUITE and Radiogenomics consortium

[24] Collins GS, Reitsma JB, Altman DG, Moons KG. Transparent reporting of a multivariable prediction model for individual prognosis or diagnosis (TRIPOD): the TRIPOD statement. $\mathrm{Br} J$ Cancer. 2015 Jan 20;112(2):251-9.

[25] Lambin P, Zindler J, Vanneste BG, De Voorde LV, Eekers D, Compter I, Panth KM, Peerlings J, Larue RT, Deist TM, Jochems A, Lustberg T, van Soest J, de Jong EE, Even AJ, Reymen B, Rekers N, van Gisbergen M, Roelofs E, Carvalho S, Leijenaar RT, Zegers CM, Jacobs M, van Timmeren J, Brouwers P, Lal JA, Dubois L, Yaromina A, Van Limbergen EJ, Berbee M, van Elmpt W, Oberije C, Ramaekers B, Dekker A, Boersma LJ, Hoebers F, Smits KM, Berlanga AJ, Walsh S. Decision support systems for personalized and participative radiation oncology. Adv Drug Deliv Rev. 2016 Jan 14. pii: S0169-409X(16)30008-4.

[26] http://ipdas.ohri.ca/

[27] Lambin P, van Stiphout RG, Starmans MH, Rios-Velazquez E, Nalbantov G, Aerts HJ, Roelofs E, van Elmpt W, Boutros PC, Granone P, Valentini V, Begg AC, De Ruysscher D, Dekker A. Predicting outcomes in radiation oncology--multifactorial decision support systems. Nat Rev Clin Oncol. 2013 Jan;10(1):27-40.)

[28] Lambin P, Roelofs E, Reymen B, Velazquez ER, Buijsen J, Zegers CM, Carvalho S, Leijenaar RT, Nalbantov G, Oberije C, Scott Marshall M, Hoebers F, Troost EG, van Stiphout RG, van Elmpt W, van der Weijden T, Boersma L, Valentini V, Dekker A. Rapid Learning health care in oncology' - An approach towards decision support systems enabling customised radiotherapy'. Radiother Oncol. 2013 Aug 28.

[29] Rekers NH, Zegers CM, Germeraad WT, Dubois L, Lambin P. Long-lasting antitumor effects provided by radiotherapy combined with the immunocytokine L19-IL2. Oncoimmunology. 2015 Apr 2;4(8):e1021541.

[30] Rekers NH, Troost EG, Zegers CM, Germeraad WT, Dubois LJ, Lambin P. Stereotactic ablative body radiotherapy combined with immunotherapy: present status and future perspectives. Cancer Radiother. 2014 Oct;18(5-6):391-5.

[31] Zegers CM, Rekers NH, Quaden DH, Lieuwes NG, Yaromina A, Germeraad WT, Wieten L, Biessen EA, Boon L, Neri D, Troost EG, Dubois LJ, Lambin P. Radiotherapy combined with the immunocytokine L19IL2 provides long-lasting antitumor effects. Clin Cancer Res. 2015 Mar 1;21(5):1151-60. 

Summary 

The aim of the research in this thesis is to improve patient selection and outcome of stereotactic radiosurgery (SRS) for brain metastases (BM). The hypotheses of this thesis are:

1) Individualized prognostic models predict survival and the occurrence of distant brain recurrences after SRS alone for BM more accurately than currently available prognostic models

2) A multicenter randomized phase III trial can be initiated to investigate whether SRS alone provides a better quality of life than WBRT in patients with 4 to 10 BM

3) The 1-year tumor control probability of SRS for large BM can be improved by isotoxic dose prescription (IDP) in a modelling study.

Several prognostic models were developed to predict local control, distant brain recurrences, and survival after SRS. The nomograms are especially valuable for the prediction of individualized outcome per patient. The accuracy of these individualized models can be optimized with the incorporation of more patient characteristics, treatment characteristics, tumor characteristics, and imaging characteristics with the aim to support shared decision making of the patient with his/her physician.

The multicenter study is currently ongoing. In June 2017, 7 Dutch hospitals opened for accrual and an additional 6 Dutch hospitals are willing to join. We are currently discussing the trial with potential participation of hospitals from the United Kingdom, Belgium, Germany, and Italy. We are cooperating with centers in the United States and Canada to optimize the SRS technique. This and other studies will define the role of SRS in the treatment of patients with multiple BM. Moreover, SRS as a technique for patients with multiple BM will become available inside and outside the Netherlands as a modality for other types of studies, for example, SRS combined with immunotherapy.

In the modelling study, IDP increased local control safely with SRS in large BM with a low radionecrosis $(\mathrm{RN})$ risk. With solid outcome registration, the observed outcome will be compared to the expected outcome in clinical practice. By applying this model-based approach a randomized trial is not needed to replace standard SRS dose prescription with IDP in daily clinical practice. To achieve an optimal therapeutic ratio, margins around the BM should be minimized or avoided. Moreover, the SRS technique should be optimized to optimize treatment accuracy and achieve steep dose gradients outside the $\mathrm{BM}$ to minimize the risk of $\mathrm{RN}$.

In conclusion, the developed individualized prognostic models and the results of the ongoing multicenter study in patients with multiple BM will contribute to better patient selection. The hope is that the process of shared decision making between the patient with his/her physician is better supported. By application of IDP, especially in large BM, the clinical outcome with respect to local control, toxicity, and survival after SRS for BM is expected to improve. 

Samenvatting 

Met het onderzoek dat beschreven is in dit proefschrift is getracht om patiëntselectie en uitkomst te verbeteren van stereotactisch radiochirurgie (SRS) als behandeling voor patiënten met hersenmetastasen (HM). De hypotheses in dit proefschrift zijn:

1) Geïndividualiseerde prognostische modellen voorspellen overleving en het ontstaan van nieuwe hersenmetastasen beter na SRS voor patiënten met HM dan bestaande prognostische modellen

2) Een gerandomiseerde multicenter studie kan worden geïnitieerd in Nederland om te onderzoeken of de kwaliteit van leven beter is na SRS dan na totale schedelbestraling bij patiënten met minimaal 4 en maximaal $10 \mathrm{HM}$.

3) De kans op lokale controle 1 jaar na SRS bij grote HM kan veilig worden verbetert met isotoxisch voorschrijven van de radiotherapiedosis

Verschillende prognostische modellen werden ontwikkeld om lokale controle, het ontstaan van nieuwe HM en overleving te voorspellen na SRS voor HM. Met name de nomogrammen zijn waardevol om geïndividualiseerd uitkomst te voorspellen per patiënt. De nauwkeurigheid van deze geïndividualiseerde prognostische modellen kan worden geoptimaliseerd door meer patiënt-, behandeling-, tumor- en beeldvorming eigenschappen toe te voegen. Het uiteindelijke doel is betere ondersteuning voor shared decision making van de patiënt met zijn/haar arts.

De Nederlandse multicenter studie is opgestart en in september 2017 waren 9 deelnemende centra open om patiënten te includeren. Nog 4 andere Nederlandse ziekenhuizen zijn geïnteresseerd in deelname. Ook vindt overleg plaats met ziekenhuizen in het Verenigd Koninkrijk, België, Duitsland en Italië voor deelname aan de studie. Er is tevens samenwerking opgezet met ziekenhuizen in de Verenigde Staten en Canada om de SRS techniek te optimaliseren. Deze en andere studies zullen de indicatie voor SRS als behandeling voor patiënten met multipele hersenmetastasen vaststellen. Tevens komt SRS beschikbaar in Nederland en in het buitenland als behandeling voor andere type studies, bijvoorbeeld gecombineerd met immuuntherapie.

In de modeleringsstudie bleek het mogelijk te zijn om met isotoxisch voorschrijven de kans op lokale controle veilig te verhogen met SRS voor HM terwijl tegelijkertijd het risico op radionecrose laag gehouden werd. Met goede uitkomst registratie zal de voorspelde uitkomst vergeleken worden met de daadwerkelijke uitkomst. Door toepassing van deze modelmatige benadering is een gerandomiseerde studie niet nodig voor klinische implementatie. Om een optimale therapeutische breedte te creëren dienen marges rondom de HM tijdens het intekenen geminimaliseerd of vermeden te worden. Tevens dient de SRS-techniek geoptimaliseerd te worden om de nauwkeurigheid van de behandeling te optimaliseren en om steile dosisgradiënten te bereiken buiten het doelgebied om het risico op RN te minimaliseren. 
Concluderend dragen de ontwikkelde geïndividualiseerde prognostische modellen en de resultaten van de opgestarte gerandomiseerde trial bij aan betere patiënten selectie en voorlichting voor de indicatiestelling voor SRS als behandeling voor patiënten met HM. De verwachting is dat het proces van gezamenlijke besluitvorming voor behandelingen door patiënt samen met zijn behandelend arts (shared decision making) beter ondersteund wordt. Door isotoxisch voor te schrijven wordt verwacht dat de klinische uitkomsten van SRS voor patiënten met HM wat betreft lokale controle, toxiciteit en overleving zullen verbeteren. 
Valorisation 

Every year, approximately 75.000 cancer patients in the Netherlands develop brain metastases (BM).[1] Treatment for BM may have considerable impact on the national health care budget because of the number of patients affected. Traditionally, whole brain radiotherapy (WBRT) was the cornerstone of the treatment. Stereotactic radiosurgery (SRS) became available as an alternative for WBRT for patients with a limited number of brain metastases. [2] With SRS, several side effects of WBRT may be avoided, such as hair loss, fatigue, and neurocognitive damage.[3] In the Netherlands, the costs of WBRT are depend on contracts between the treating hospital and the insurance company and may differ per center. The content of these contracts is confidential. A crude estimation is that the costs of WBRT are around 4000 to 6000 euros and for SRS treatment around 6000 to 8000 euros. For patients with BM, SRS is more cost-effective than WBRT for patients with a limited life expectancy by the avoidance of costs related to neurocognitive side effects despite initial higher treatment costs as was published in American studies.[4,5] The exact cost-effectivity of SRS compared to WBRT or WBRT combined with SRS should also be studied specifically for the situation in the Netherlands.

The development of accurate prognostic models and shared decision tools allows individualized patient information per treatment modality. This may diminish the problem of over-treatment and intensive follow-up schemes for poor prognosis patients with BM. If patients are informed that there is a significant risk of dying within 3 months after treatment despite SRS, they may instead choose best supportive care.[6] Patients who have a low probability of long-term survival may choose not to undergo aggressive extracranial treatments, such as a 5 week treatment of chemotherapy and radiotherapy on the primary extracranial tumor with its morbidity and mortality. Patients who have only a low risk of developing distant brain recurrences (DBR) may choose not to undergo follow-up MRIs. All these choices may result in less treatment and imaging during follow-up of patients with BM and a reduction in the costs of their treatment.

Another opportunity to optimize cost-effectiveness is the potential avoidance of systemic therapies for patients with BM. For example, in a large trial in patients with a maximum of 3 BM of non-small cell lung cancer, RT only (WBRT + SRS) resulted in improved survival compared to combining RT with erlotinib or combining RT with temozolomide.[7] This can be explained by additional side effects caused by combining RT with relatively ineffective systemic agents, which may result in decreased general health condition and thereby survival. Because the RT-only arm resulted in the best survival, it is obvious that both trial arms with the combination treatments (RT + erlotinib or RT + temozolomide) are less cost-effective by additional costs of the systemic agents with even a detrimental effect on survival compared to RT only. One year of treatment with a daily dose of $150 \mathrm{mg}$ erlotinib costs 28.568 Euros in the Netherlands. One year of treatment with a daily dose of 100 mg temozolomide costs 6732 Euros in the Netherlands (www.medicijnkosten.nl). Thus, combining systemic agents with RT will only be 
cost-effective if survival is actually improved over RT only and additional side effects of combining treatments are absent.

Another opportunity to optimize cost-effectiveness is the application of isotoxic dose prescription (IDP). With IDP, the risk of radionecrosis (RN) is low because the SRS dose is prescribed based on normal tissue tolerance levels. With standard risk-adapted SRS dose prescription in large BM, there is a relatively low risk of local control and a relatively high risk of RN.[8] Application of IDP in large inoperable BM (for example, PTV > 10 $\mathrm{cm}^{3}$ ) is expected to result in a lowering of the incidence of RN compared to the current daily clinical practice. Patients suffering from RN become often dependent on steroids. Steroids have significant side effects such as a risk of diabetes mellitus with a need for medication, myopathy with a need for adaptations at home in daily care, and sleepiness with a need for medications. Symptoms resulting from RN and side effects resulting from steroids may also increase health care costs. It is to be expected that the application of IDP in daily clinical practice with SRS for BM will result in a reduction in costs due to a lower incidence of RN and simultaneously an increase in cost-effectivity by higher local control probability in large BM. 


\section{REFERENCES}

[1] www.kankerregistratie.nl

[2] Zindler JD, Rodrigues G, Haasbeek CJ, Haan PF, Meijer OW, Slotman BJ, Lagerwaard FJ. The clinical utility of prognostic scoring systems in patients with brain metastases treated with radiosurgery. Radiother Oncol 2013 Mar;106(3):370-4.

[3] Soffietti R, Kocher M, Abacioglu UM, Villa S, Fauchon F, Baumert BG, Fariselli L, Tzuk-Shina T, Kortmann RD, Carrie C, Ben Hassel M, Kouri M, Valeinis E, van den Berge D, Mueller RP, Tridello G, Collette L, Bottomley A. A European Organisation for Research and Treatment of Cancer phase III trial of adjuvant whole-brain radiotherapy versus observation in patients with one to three brain metastases from solid tumors after surgical resection or radiosurgery: quality-of-life results. J Clin Oncol. 2013 Jan 1;31(1):6572.

[4] Hall MD, McGee JL, McGee MC, Hall KA, Neils DM, Klopfenstein JD, Elwood PW. Cost-effectiveness of stereotactic radiosurgery with and without whole-brain radiotherapy for the treatment of newly diagnosed brain metastases. J Neurosurg. 2014 Dec;121 Suppl:84-90.

[5] Lester-Coll NH, Dosoretz AP, Magnuson WJ, Laurans MS, Chiang VL3, Yu JB. Cost-effectiveness of stereotactic radiosurgery versus whole-brain radiation therapy for up to 10 brain metastases. J Neurosurg. 2016 Dec;125(Suppl 1):18-25.

[6] Zindler JD, Jochems A, Lagerwaard FJ, Beumer R, Troost EG, Eekers DB, Compter I, Van der Toorn PP, Essers M, Oei B, Hurkmans CW, Bruynzeel AM, Bosmans G, Swinnen A, Leijenaar RT; Lambin P. Individualized early death and long-term survival prediction after stereotactic radiosurgery for brain metastases of non-small cell lung cancer: two externally validated nomograms - submitted

[7] Sperduto PW, Wang M, Robins HI, Schell MC, Werner-Wasik M, Komaki R, Souhami L, Buyyounouski MK, Khuntia D, Demas W, Shah SA, Nedzi LA, Perry G, Suh JH, Mehta MP. A phase 3 trial of whole brain radiation therapy and stereotactic radiosurgery alone versus WBRT and SRS with temozolomide or erlotinib for non-small cell lung cancer and 1 to 3 brain metastases: Radiation Therapy Oncology Group 0320. Int J Radiat Oncol Biol Phys. 2013 Apr 1;85(5):1312-8.

[8] Zindler JD, Schiffelers J, Lambin P, Hoffmann A. Individualized isotoxic dose prescription for stereotactic radiotherapy in large brain metastases: an in-silico study - submitted. 

Dankwoord 

Mijn droom is uitgekomen. Ik ben neuro- en hoofdhals radiotherapeut en onlangs heb ik de kans gekregen om de patiëntenzorg met neuroradiotherapie onderzoek te combineren. Veel mensen binnen MAASTRO Clinic, MUmc+ Maastricht, het VUmc Amsterdam en daarbuiten ben ik hiervoor dank verschuldigd en zeker voor het tot stand komen van dit proefschrift. In de 16 jaar dat ik nu onderzoek doe heb ik ontzettend veel geleerd, maar zeker ook de afgelopen 4 jaar als radiotherapeut-oncoloog in MAASTRO Clinic.

In het bijzonder wil ik Philippe Lambin, Frank Lagerwaard, Aswin Hoffmann en Arthur Jochems bedanken voor hun uitzonderlijke hulp en begeleiding bij het voltooien van dit proefschrift. Jullie hebben mij gesteund, steeds weer nieuwe inzichten gegeven, gestimuleerd tot doorzetten en met jullie individuele kwaliteiten mijn onderzoek op een hoger niveau gebracht. Philippe, jij legt meteen bij artikelen de vinger op de zere plek en zet de hoofdlijnen strak neer. Hierdoor werd het onderzoek in een veel bredere context geplaatst en heb je me laten samenwerken met veel gedreven onderzoekers. Jij hebt me altijd opties laten zien en me gesteund om barrières het hoofd te bieden. Frank, zonder jou was dit proefschrift nooit tot stand gekomen. Jij hebt me geleerd over de do's en don'ts in klinisch onderzoek en om complexe problemen helder in klinisch perspectief te zetten. Dit geldt voor het maken van een database, de analyses, maar zeker ook tijdens het schrijven van alle artikelen die we samen gepubliceerd hebben. Je bent de beste sparringpartner op onderzoeksgebied die er is. Aswin, jouw bijdrage is essentieel geweest voor ons artikel in het tijdschrift met hoge impactfactor, the Journal of National Cancer Institute. We hebben vele kritische discussies gevoerd en dat is belangrijk bij wetenschappelijk onderzoek. Jouw kennis, oog voor detail, eerlijkheid en gedrevenheid gaan je nog heel ver brengen. Wat hebben wij samen in korte tijd veel bereikt. Dank daarvoor. Esther Troost wil ik bedanken voor de samenwerking toen je nog in MAASTRO Clinic werkte. Jij hebt me enorm geholpen in de beginfase om mijn weg te vinden in Maastricht. Arthur, jouw snelheid en vaardigheden met statistiek heeft mijn onderzoek voorwaarts gebracht. Jij hebt me geleerd hoe geïndividualiseerde modellen gemaakt worden en stond altijd voor me klaar. Verder wil ik het hele onderzoeksteam, en in het bijzonder Anne Marie Bruynzeel, bedanken voor de goede samenwerking bij het opzetten van de multicenter studie voor patiënten met 4 tot 10 hersenmetastasen. Hennie van der Steeg, kunstenaar uit Nieuwstadt wil ik bedanken voor het schitterende schilderij dat je gemaakt hebt. Een foto van dit schilderij is te zien op de voorzijde van dit proefschrift. Het illustreert heel goed de inhoud en het is een blijvend aandenken voor mij aan de afgelopen jaren. Jouw overige werk is ook prachtig (voor meer informatie, sjannie.vdsteeg@gmail.com).

Ook wil ik Andre Dekker, Liesbeth Boersma en Dirk de Ruysscher bedanken voor het gestelde vertrouwen dat ik structureel onderzoekstijd krijg om samen met Frank Hoebers het onderzoek binnen de neuroradiotherapie en hoofdhalsradiotherapie vorm te geven. Het is altijd mijn droom geweest om de beste zorg te leveren voor mijn patiënten en om te pogen de behandelingen verder te verbeteren met hoogwaardig onder- 
zoek. Frank Hoebers, Piet van den Ende en Danielle Eekers, collegae radiotherapeuten binnen ons team, wil ik bedanken voor onze dagelijkse samenwerking in de behandeling van onze patiënten. We streven naar de beste zorg voor onze patiënten en gaan voor de hoogste kwaliteit in de dagelijkse hectische en drukke patiëntenzorg. Hierbij werken we samen met de radiotherapeuten van de andere teams, laboranten, klinisch fysici en physician assistants en overige medewerkers in MAASTRO Clinic die allen dank verschuldigd zijn. Verder wil ik Karin ter Haag bedanken, physician assistant in ons team; recent hebben we in samenwerking met meerdere medisch specialisten een zorgpad hersenmetastasen opgesteld wat hopelijk de kwaliteit, kosten/effectiviteit en efficiëntie in de OncoZon regio helpt te verbeteren. Ook wil ik in het bijzonder Ans Swinnen bedanken. Zij is klinisch fysicus bij ons. Wat hebben wij al veel bereikt op het gebied van innovatie. Het is een plezier om met zo een gedreven en innovatieve klinisch fysicus samen te werken, die ook constant op zoek is naar verbetering van de uitkomst van de patiënt door onze technieken te optimaliseren. Zonder jouw trekkende rol en streven naar de hoogste kwaliteit betwijfel ik of de klinische implementatie van stereotactische bestraling van wervelmetastasen en multipele hersenmetastasen gelukt was. Hierbij was de samenwerking met Chin Loon Ong, inmiddels ook klinisch fysicus, ook zeer waardevol. Verder wil ik Bas Nijsten, hoofd van de klinisch fysici, bedanken dat hij alle innovatie mogelijk maakt voor onze patiënten. Verder wil ik Rosemarijne Beumer en Janna Seubers, beiden student geneeskunde bedanken voor onze samenwerking bij mijn onderzoek. Ik hoop dat jullie enthousiast zijn geworden en wie weet promoveren jullie zelf in de nabije toekomst. Jos Jager en Jacques Borger wil ik danken voor de gezelligheid en samenwerking in de eerste jaren bij MAASTRO Clinic. Jammer dat jullie allebei met pensioen zijn. Bijzondere dank wil ik nog uitbrengen naar Ann Hoeben, medisch oncoloog en motor van onze neuro-oncologische OncoZon werkgroep. Jouw gedrevenheid om de gehele werkgroep op een hoog multidisciplinair klinisch en wetenschappelijk niveau te brengen is essentieel. De overige leden van de OncoZon werkgroepen neuro- en hoofdhals oncologie wil ik ook bedanken voor de prettige en gedreven samenwerking. Ook Lizza Hendriks en Anne-Marie Dingemans, longartsen in het MUmc+, wil ik bedanken voor de samenwerking. Jullie hebben specifieke interesse om de zorg voor patiënten met hersenmetastasen te verbeteren met nieuwe behandelingen en staan aan de internationale top. Ik hoop dat we samen met Dirk de Ruysscher baanbrekende studies gaan doen met een multidisciplinair karakter.

Verder wil ik Joke, Marc, Hero en Heleen bedanken voor onze samenwerking in Rotterdam. Mijn eerste stapjes in het wetenschappelijk onderzoek heb ik samen met jullie gezet. Dank voor jullie begeleiding.

Mama en papa, dankjulliewel dat jullie me altijd steunen in alles wat ik tot nu toe gedaan heb. Maartje, Anke en Wim, fijn dat wij als broers en zussen zo een goed contact hebben, elkaar steunen en elkaars kinderen zien opgroeien. Verder wil ik ook mijn overige familie, vrienden en collegae buiten MAASTRO bedanken en in het bijzonder Rik, 
Laurens, Martijn, Maarten, Ralph, Diederik, Stephan, Alphons, Jacques, Friso en Jurriaan; dank dat we nog altijd vrienden zijn ondanks dat we allen ons eigen pad zijn gegaan. Ook vind ik het erg leuk dat we nog altijd onderling contact hebben met de AIOS groep uit het VUmc en met mijn huisgenoten uit mijn studententijd in Delft.

Nadine, lieve schat en moeder van onze zoon Alexander, dankjewel dat je er altijd voor me bent, ook op de momenten dat het tegenzit. Al jaren beleven we ongelooflijk veel samen en komen we op vele plekken. Jij, Alexander en mijn patiënten geven me elke dag de kracht om het beste uit mezelf te halen op mijn werk en thuis. 



\section{Curriculum vitae}

Jaap Doeke Zindler was born on October 23, 1979, in Haarlem, the Netherlands. He is married and has a son, and lives in Maastricht, the Netherlands. His hobbies are windsurfing and playing the piano. In 1998, he finished his secondary education at the Sancta Maria Lyceum in Haarlem. In 1999, he finished his propedeutical exam in civil engineering at the Technical University of Delft, and thereafter started medical school at the Erasmus University in Rotterdam. For 16 years he has been doing research starting in the second year of medical school. He was involved in basic, translational, and clinical studies, and (co-)authored 20 peer reviewed papers and gave 8 oral presentations at national and international conferences. He has reviewed scientific articles for several high-impact international journals, such as JAMA Oncology, Radiotherapy \& Oncology, and Journal of Thoracic Disease. He has done several internships abroad such as a research internship at the Johns Hopkins Institute in Baltimore, Maryland, in the United States and a research internship at the Universitat de Barcelona, Spain. He did a clinical internship surgery at the Pontificia Universidad Catolica, Santiago, Chile. After obtaining his medical degree in 2006, he gained further research experience at the Erasmus University Rotterdam, and clinical experience at the department of Neurology of the Oosterschelde Ziekenhuis, Goes, the Netherlands. In 2008, he started his residency in radiation oncology at VU Medical Center in Amsterdam. During his residency, he was involved in several research projects and had a special preference for research in the field of neuro-oncology. In 2013, he obtained his degree as a radiation oncologist and got the opportunity to work at MAASTRO Clinic Maastricht. In Maastricht, he finished this thesis in 2017. Currently, he is a full-time radiation oncologist with a focus on neuro oncology, head and neck cancer, and stereotactic radiotherapy for oligometastases, actively combining clinical with research activities. He leads several clinical and research projects in cooperation with other institutes, such as a multicenter prospective randomized phase III trial and the clinical implementation of proton therapy for head and neck cancer patients. He is a member of several national and international (radiation) oncology organizations. He is a member of the committee of the Dutch guideline for the treatment of brain metastases (LWNO). He was recently selected to lead the research in the coming years of neuro- and head \& neck radiotherapy together with Frank Hoebers at the MAASTRO Clinic. 



\section{List of peer reviewed publications}

1) Zindler JD, Schiffelers J, Lambin P, Hoffmann A; Improved effectiveness of stereotactic radiosurgery in large brain metastases by individualized isotoxic dose prescription submitted for publication

2) Jeene P, de Vries K, van Nes J, Kwakman J, Wester G, Rozema T, Braam P, Zindler J, Koper P, Nuyttens J, Vos-Westerman H, Schmeets I, Niël C, Hutschemaekers S, van der Linden Y, Verhoeff J, Stalper J. Survival after Whole Brain Radiotherapy for Brain Metastases from Lung Cancer and Breast Cancer is poor in 6,325 Dutch patients treated between 2000 and 2014 - submitted for publication

3) Zindler JD, Bruynzeel AME, Eekers DBP, Hurkmans CW, Swinnen A, Lambin P. Whole brain radiotherapy versus stereotactic radiosurgery for 4-10 brain metastases: a phase III randomised multicentre trial: study protocol. BMC Cancer 2017 Jul 25;17(1):500. Impact factor 3.4

4) Zindler JD, Jochems A, Lagerwaard FJ, Beumer R, Troost EG, Eekers DB, Compter I, van der Toorn PP, Essers M, Oei B, Hurkmans CW, Bruynzeel AM, Bosmans G, Swinnen A, Leijenaar RT, Lambin P. Individualized early death and long-term survival prediction after stereotactic radiosurgery for brain metastases of non-small cell lung cancer: Two externally validated nomograms. Radiother Oncol. 2017 Feb 23. pii: S0167-140(17) 30065-8

Impact factor: 4.9

5) Verduin M, Zindler JD, Martinussen HM, Jansen RL, Croes S, Hendriks LE, Eekers DB, Hoeben A. Use of Systemic Therapy Concurrent With Cranial Radiotherapy for Cerebral Metastases of Solid Tumors. Oncologist. 2017 Feb;22(2):222-235 Impact factor 4.5

6) Lambin P, Zindler J, Vanneste B, De Voorde LV, Eekers D, Compter I, Panth K, Peerlings J, Larue R, Deist $T$, Jochems A, Lustberg T, van Soest J, de Jong E, Even A, Reymen B, Rekers N, van Gisbergen M, Roelofs E, Carvalho S, Leijenaar R, Zegers C, Jacobs M, van Timmeren J, Brouwers P, Lal J, Dubois L, Yaromina A, Van Limbergen EJ, Berbee M, van Elmpt W, Oberije C, Ramaekers B, Dekker A, Boersma L, Hoebers F, Smits K, Berlanga A, Walsh S. Decision support systems for personalized and participative radiation oncology. Adv Drug Deliv Rev. 2016 Jan 14

Impact factor 15.4 
7) Zindler JD, Thomas CR, Hahn SM, Hoffmann AL, Troost EGC, Lambin P. Increasing the therapeutic ratio of stereotactic ablative radiotherapy by individualized isotoxic dose prescription based on normal tissue tolerance levels. J Natl Cancer Inst. 2015 Oct $16 ; 108(2)$

Impact factor 12.6

8) Lambin P, Zindler J, Vanneste B, van de Voorde L, Jacobs M, Eekers D, Peerlings J, Reymen B, Larue RT, Deist TM, de Jong EE, Even AJ, Berlanga AJ, Roelofs E, Cheng Q, Carvalho S, Leijenaar RT, Zegers CM, van Limbergen E, Berbee M, van Elmpt W, Oberije C, Houben R, Dekker A, Boersma L, Verhaegen F, Bosmans G, Hoebers F, Smits K, Walsh S. Modern clinical research: How rapid learning health care and cohort multiple randomised clinical trials complement traditional evidence based medicine. Acta Oncol. 2015;54(9):1289-300

Impact factor 3.0

9) Hendriks LE, Schoenmaekers J, Zindler JD, Eekers DB, Hoeben A, De Ruysscher DK, Dingemans AM. Safety of cranial radiotherapy concurrent with tyrosine kinase inhibitors in non-small cell lung cancer patients: A systematic review. Cancer Treat Rev. 2015 Jul;41(7):634-45

Impact factor 7.6

10) Zindler JD, Slotman BJ, Lagerwaard FJ. Patterns of distant brain recurrences after radiosurgery alone for newly diagnosed brain metastases: Implications for salvage therapy. Radiother Oncol. 2014 Jul 28.S0167-8140(14)00293

Impact factor: 4.9

11) Rodrigues G, Warner A, Zindler JD, Slotman BJ, Lagerwaard FJ. A Clinical Nomogram and Recursive Partitioning Analysis to Determine the Risk of Regional Failure after Radiosurgery Alone for Brain Metastases Radioth Oncol 2014 Apr;111(1):52-8 Impact factor: 4.9

12) Zindler JD, Gijtenbeek JMM, Lagerwaard FJ. Postoperative management after resection of a single brain metastasis: whole brain radiotherapy, local radiotherapy, or 'wait and scan'? Dutch Journal of Oncology. Dutch Journal of Oncology 2013;10(8):318-23 Impact factor: unknown

13) Zindler JD, Rodrigues G, Haasbeek CJ, Haan PF, Meijer OW, Slotman BJ, Lagerwaard FJ. The clinical utility of prognostic scoring systems in patients with brain metastases treated with radiosurgery. Radiother Oncol 2013 Mar;106(3):370-4 Impact factor: 4.9

14) Rodrigues G, Zindler JD, Warner A, Lagerwaard FJ. Recursive Partitioning Analysis for the Prediction of Stereotactic Radiosurgery Brain Metastases Lesion Control. The Oncologist 2013;18(3):330-5

Impact factor 4.5 
15) Rodrigues G, Zindler JD, Warner A, Bauman G, Senan S, Lagerwaard FJ. Propensityscore matched pair comparison of whole brain with simultaneous in-field boost radiotherapy and stereotactic radiosurgery. Radiother Oncol. 2012 Dec 4; pii: S01678140(12)00471-9

Impact factor: 4.9

16) Dahele M, Zindler JD, Sanchez E, Verbakel WF, Kuijer JP, Slotman BJ, Senan S: Imaging for stereotactic spine radiotherapy: clinical considerations. Int J Radiat Oncol Biol Phys. 2011 Oct 1;81(2):321-3

Impact factor: 4.2

17) Van Beusekom HM, Saia F, Zindler JD, Lemos PA, Hoor SL, van Leeuwen MA, de Feijter PJ, Serruys PW, van der Giessen WJ: Drug-eluting stents show delayed healing: paclitaxel more pronounced than sirolimus. Eur Heart J. 2007 Apr;28(8):974-9

Impact factor: 14.7

18) Zindler JD, Hendriks JM, Koudstaal PJ, Pattynama PMT, Van Sambeek MRHM, Van Dijk LC: Carotis stenting met cerebrale bescherming bij patiënten met een symptomatische en significante carotis stenose. Ned Tijdschr van Geneesk. 2006 Apr 1;150(13):7304

Impact factor: 2.2

19) Hendriks JM, Zindler JD, Lugt van der A, Pattynama PMT, Sambeek van MRHM, Bosch JL, Dijk van LC: Embolic protection filters for carotid stenting: differences in flow obstruction depending on filter construction. J Endovasc Ther. 2006 Feb;13(1):47-50 Impact fator: 3.6

20) Hendriks JM, Zindler JD, Dijk van LC, Van Sambeek MR: Cerebral protection during percutaneous carotid intervention: wich device should be used ? Acta Chir Belg. '04 Jun;104(3):300-3

Impact factor: 0.4 



\section{Scientific presentations at international and national conferences}

1) Brain tumors in 2018: are there still unsolved problems? upcoming ESTRO Barcelona Spain 2018 invited co-chair scientific session

2) This house believes that stereotactic radiosurgery will replace whole brain radiotherapy in patients with ten brain metastases; upcoming ESTRO Barcelona Spain 2018 invited speaker

3) Radiation therapy for brain metastases; ESMO lung cancer conference Geneva Swiss 2017 invited speaker

4) Stereotactic radiosurgery versus whole brain radiotherapy in patients with 4 up to 10 brain metastases: a prospective phase III multicentre study; Varian User Meeting Chicago USA 2017 oral presentation

5) Stereotactic radiosurgery versus whole brain radiotherapy in patients with 4 up to 10 brain metastases: a prospective phase III multicentre study; Symposium Catharina Ziekenhuis Eindhoven 2017 invited speaker

6) Towards shared decision: validated clinical nomogram for personalized long term survival prediction after radiosurgery for brain metastases. ASTRO Boston USA 2016 oral presentation

7) Single-fraction dose prescription in LINAC-based stereotactic radiosurgery of spherical brain metastases: influence of GTV size, applied margins and photon beam arrangements. ISRS Yokohama Japan 2015 oral presentation

8) Predicting survival after stereotactic radiotherapy for 1 upto 4 brain metastases: Simplified Recursive Partitioning analysis (SRPA). ESTRO Barcelona Spain 2015 oral presentation

9) Personalized radiotherapy for primary lung cancer: Radiological Society of North America (RSNA); Chicago USA 2014 invited key note speaker 